UNIVERSIDADE DE SÃO PAULO

FACULDADE DE EDUCAÇÃO

DORALICE BORTOLOCI FERREIRA

DOCÊNCIA: ELEMENTOS DE SUSTENTAÇÃO

São Paulo

2008 
DORALICE BORTOLOCI FERREIRA

\section{DOCÊNCIA: ELEMENTOS DE SUSTENTAÇÃO}

Tese apresentada à Faculdade de Educação da Universidade de São Paulo para obtenção do título de Doutor em Educação

Área de Concentração: Ensino de Ciências

Orientador: Prof. Dr. Alberto Villani.

São Paulo

2008 


\section{FOLHA DE APROVAÇÃO}

Doralice Bortoloci Ferreira

Docência: elementos de sustentação

Tese apresentada à Faculdade de Educação da Universidade de São Paulo para obtenção do título de Doutor.

Área de Concentração: Ensino de Ciências.

Aprovado em:

Banca Examinadora

Prof. Dr Denise Freitas

Instituição Faculdade Educação- UFSCAR_Assinatura

Prof. Dr Elizabeth Barolli

Instituição Faculdade Educação- Unicamp_ Assinatura

Prof. Dr Maria Cecília Cortez Christiano de Souza

Instituição Faculdade Educação- FEUSP

Assinatura

Prof. Dr Mônica Guimarães Teixeira do Amaral

Instituição Faculdade Educação- FEUSP

Assinatura

Prof. Dr Alberto Villani

Instituição Instituto de Física- IFUSP

Assinatura 


\section{DEDICATÓRIA}

Dedico esse trabalho aos professores que compartilharam generosamente suas histórias e tornaram possível ampliar a busca de respostas sobre a nossa profissão.

Aos meus irmãos Renato, Lídia, Beatriz, Judite, Vicente, Gilberto e Eulina, que carregam fragmentos da nossa memória e que só se recompõem quando estamos juntos.

A Thomaz e Janaína, que as melhores escolhas os conduzam ao conhecimento e lhes mostrem os caminhos que valem a pena percorrer. 


\section{AGRADECIMENTOS}

É comum nesse momento trazer a tona o grau de renúncia necessário e, principalmente, as dificuldades físicas, emocionais e até mesmo psicológicas que são acionadas durante e para a elaboração de uma pesquisa.

Nesse processo o apoio dos familiares, amigos e interlocutores torna-se decisivo para a obtenção de um resultado satisfatório. Exatamente por esse motivo, muitos devem ser os agradecimentos e por mais que me policie vou acabar esquecendo alguém. Mas fazer o quê? Agradeço inicialmente ao Villani que me orientou nessa árdua etapa de aprender a fazer pesquisa. Com suas oportunas observações de um pesquisador inconteste soube dar a um conjunto de expectativas, dúvidas e incertezas um sentido para a busca de respostas da nossa questão de pesquisa.

Ao Grupo de Pesquisa que me ouviu, me questionou, me deixou sem saídas e me ajudou a reencontrá-las.

À Banca de Qualificação, Cecília e Denise que com suas orientações conseguiram colocar o trabalho nos eixos fornecendo não só uma estruturação, mas também os questionamentos capazes de permitir maior avanço.

$\grave{A}$ amiga Beth que em momento cruciais me ajudou a tomar as melhores decisões, as mais promissoras.

Às amigas Joana e Valéria, pela paciência, leituras e inúmeras sugestões.

À Nina, minha aluna, pelas primeiras leituras, correções e incentivo.

Ao Felippe que me apoiou, assumiu as questões pessoais, me deu o tempo necessário e constantemente me redirecionou para este trabalho. 


\section{EPÍGRAFE}

Eu tenho à medida que designo - e este é o esplendor de se ter uma linguagem. Mas eu tenho muito mais à medida que não consigo designar. A realidade é a matéria prima, a linguagem é o modo como vou buscá-la - e como não acho. Mas é do buscar e não achar que nasce o que eu não conhecia, e que instantaneamente reconheço. A linguagem é o meu esforço humano. Por destino tenho que ir buscar e por destino volto com as mãos vazias. Mas - volto com o indizível. O indizível só me poderá ser dado através do fracasso da minha linguagem. Só quando falha a construção, é que obtenho o que ela não conseguiu.

Clarice Lispector em A paixão segundo G.H.

LISPECTOR, C. A paixão segundo G.H. Rio de Janeiro: Editora Rocco, 1998 . 


\section{RESUMO}

FERREIRA, D. B. Docência: elementos de sustentação. 2008. 209f. Tese (Doutorado). Faculdade de Educação da Universidade de São Paulo, São Paulo, 2008.

Nas últimas décadas a profissão docente vem atravessando uma grande fase de desprestígio, pois o professor é colocado como responsável pela maioria dos insucessos da aprendizagem. Como se não bastasse para se manter nessa posição o professor necessita de um aprimoramento contínuo que inclui a utilização de teorias modernas, conhecimentos tecnológicos e, além disso, uma permanente ampliação da sua rede de saberes. O que o coloca numa situação angustiante e permanente de queixas dirigidas a todos os envolvidos no processo educativo. Mesmo diante desse quadro que está estabelecido pessoas continuam estudando para serem professores e, as que estão em sala de aula também não abandonam a profissão, o que nos faz perguntar $O$ que sustenta o professor na docência? Para responder essa questão entramos em contato com as Histórias de Vida e entrevistas de professores que cursavam uma disciplina de pós-graduação. Analisamos as Histórias de Vida utilizando o conceito de ethos modificado por Maingueneau (2005) e relacionado à Análise do Discurso e a partir do ethos discursivo obtido, organizamos as situações marcantes em termos de demandas subjetivas feitas pelo professor. Essas demandas olhadas por um novo referencial, o psicanalítico, foram caracterizadas em: dívida simbólica, reedição parental, demanda de amor e gozo. A estrutura explicativa obtida nos sugeriu uma analogia com o modelo dos Programas de Pesquisas de Lakatos (1979), pois em nossa interpretação, as condições que caracterizam o progresso ou abandono de um paradigma têm a mesma estrutura das que se referem ao progresso ou abandono da carreira docente. Inferimos finalmente que o professor se mantém na docência porque esse lugar ainda propicia condições para que ele possa atualizar e dar atendimento as suas demandas mais subjetivas. Na nossa interpretação, condições institucionais que ajudem na proteção dessas demandas primordiais também podem se constituir como fator vital para a permanência na docência.

PALAVRAS CHAVE: formação de professores; sustentação na docência; história de vida; análise do discurso; psicanálise; programas de pesquisa. 


\begin{abstract}
FERREIRA, D.B. Docência: Elementos de Sustentação. 2008. 209f. Thesis (Doctoral). Faculdade de Educação da Universidade de São Paulo, São Paulo, 2008.

In the last few decades, the teaching profession has lacked prestige, as society blames teachers for most learning failures. Additionally, teachers must improve continuously in order to maintain their jobs - it is demanded of them that they be able to use modern theories and technological knowledge, as well as that they permanently widen their knowledge network. This puts them in a distressing position, and one in which complaints are directed towards all involved in the educational process. Even facing this scenario, however, people continue to study to be teachers, and the ones currently teaching do not abandon their profession. This makes one wonder: What keeps a teacher in the teaching profession? In order to answer this question, we interviewed teachers enrolled in a postgraduate course and got acquainted with their Life Stories. We analyzed these Life Stories using the concept of ethos as modified by Maingueneau and related it to Discourse Analysis. Using the resulting discursive ethos as a starting point, we organized the noteworthy situations according to the teachers' subjective demands. These demands were then analyzed from the psychoanalytical frame of reference and characterized as: symbolic debt, new edition of parental relationships, demand for love and jouissance. The explicative structure obtained suggested an analogy with the Lakatos' Research Programs, since, in our interpretation, the conditions that characterize the progress or the abandonment of a paradigm have the same structure of those which refer to the progress or abandonment of the teaching career. Finally, we inferred that teachers keep teaching because this post still provides conditions for him or her to update and fulfill his or her most subjective demands. In our interpretation, institutional conditions which help protect these primordial demands may also constitute vital factors for the permanence of teachers in the teaching profession.
\end{abstract}

KEYWORDS: teacher formation; permanence in the teaching profession; life story; discourse analysis; psychoanalysis; research programs. 


\section{LISTA DE ILUSTRAÇÕES}

A. Diagrama explicativo da cenografia................................................. 44

B. Modelo de Lakatos da produção do conhecimento científico.............143

C. Modelo da produção e sustentação docente........................................144

D. Programas de Pesquisa(PP) de Lakatos. ..........................................148

E. Diagrama - o real, o simbólico e o imaginário..................................150

F. Diagrama - aplicado na situação de ensino........................................151 


\section{SUMÁRIO}

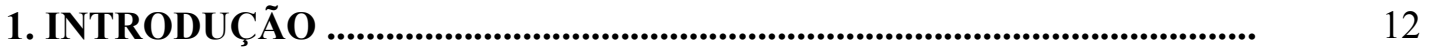

1.1. CONSIDERAÇOES INICIAIS .............................................................. 12

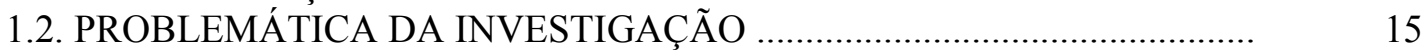

2. METODOLOGIA DA PESQUISA ................................................................. 15

2.1. HISTÓRIA DE VIDA E NARRATIVA ….......................................... 22

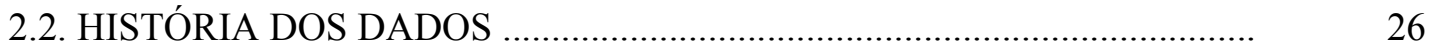

2.2.1 Primeira fase da coleta de dados ......................................................... 28

2.2.1.1 Procedimento na coleta de dados da primeira fase .................................. 33

2.2.2 Segunda fase da coleta de dados ..........................................................

2.2.3. Critério de escolha final dos dados ......................................................

3. REFERENCIAL TEÓRICO …..............................................................

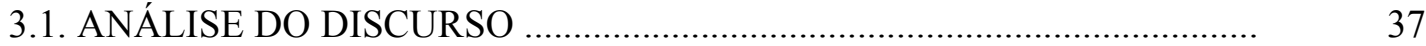

3.2. ETHOS E ANÁLISE DO DISCURSO …...................................................

4. AS HISTÓRIAS DE VIDA: ORGANIZAÇÃO E ANÁLISE...........................

4.1. A ANÁLISE DO DISCURSO COMO REFERÊNCIA PARA

ARTICULAR ELEMENTOS PRESENTES NAS HISTÓRIAS DE VIDA ........ 45

4.1.1. Madalena .................................................................................

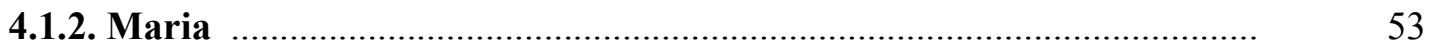

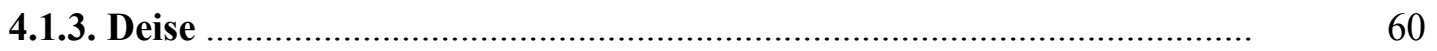

4.1.4. João ……........................................................................................

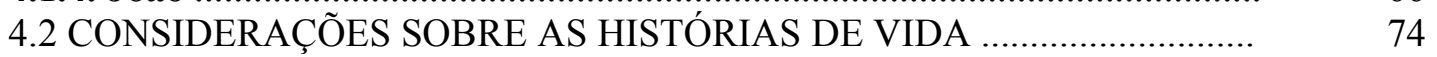

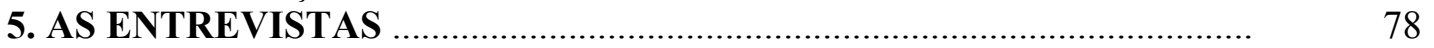

5.1 ANALISANDO AS ENTREVISTAS …...................................................

5.2 CONSIDERAÇÕES SOBRE AS ENTREVISTAS ….................................. 83

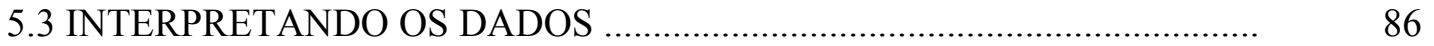

6. UM NOVO REFERENCIAL DE ANÁLISE ............................................ 90

6.1. O REFERENCIAL PSICANALÍTICO .................................................... 90

6.1.1. A Constituição do Sujeito ................................................................. 91

6.1.2. Os Três Registros Psicanalíticos: o imaginário, o real e o simbólico ... 95

6.1.3. Os elementos Psicanalíticos utilizados ................................................... 97

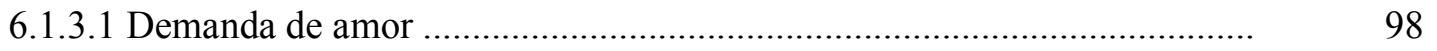

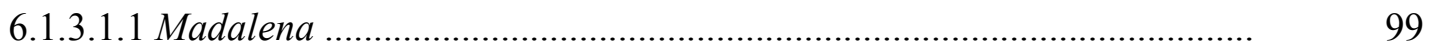

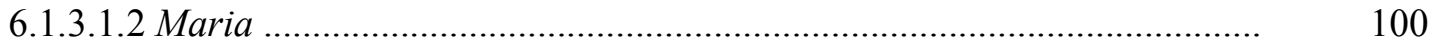

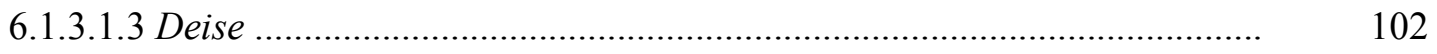

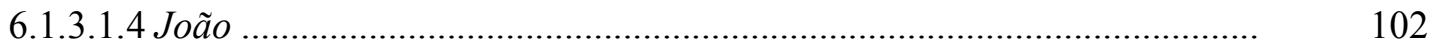

6.1.3.2 A reedição da situação parental ............................................................. 104

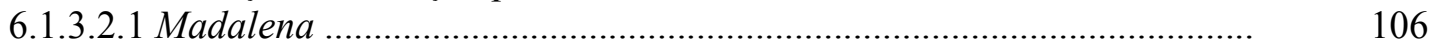

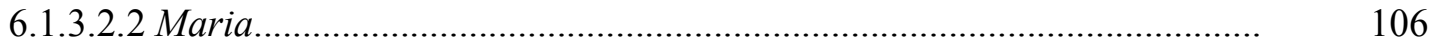

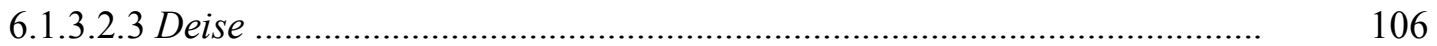

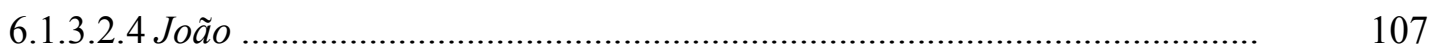

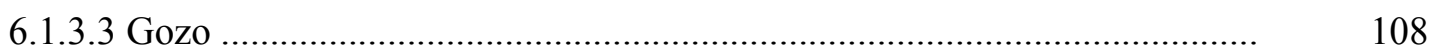

6.1.3.3.1 Madalena ..................................................................... 110

6.1.3.3.2 Maria .................................................................................. 112

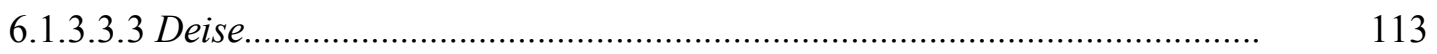

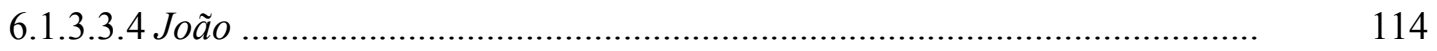




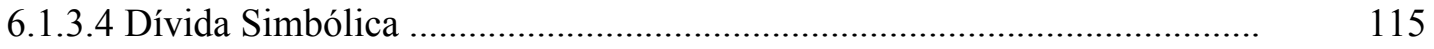

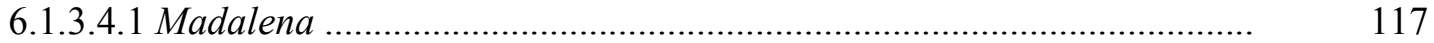

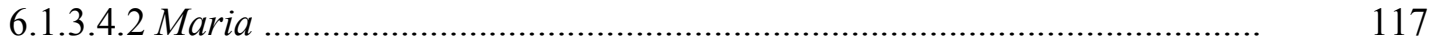

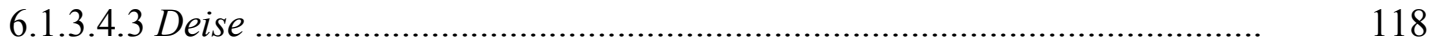

6.1.3.4.4 João ................................................................................................... 119

6.2 CONSIDERAÇÕES SOBRE A UTILIZAÇÃO DO REFERENCIAL

PSICANALÍTICO .............................................................................. 122

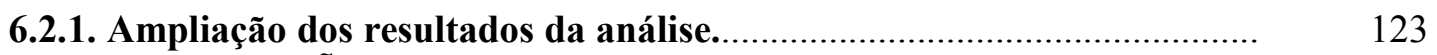

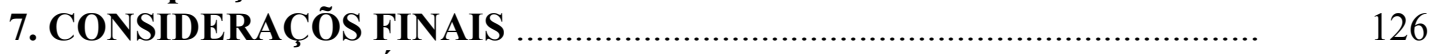

7.1. MAIS UMA HISTÓRIA DE VIDA ….................................................. 128

7.2. ANALOGIA COM ARRUDA e UENO (2003) .......................................... 131

7.3. ANALOGIA COM A IMAGEM DO MODELO DE LAKATOS ................ 136

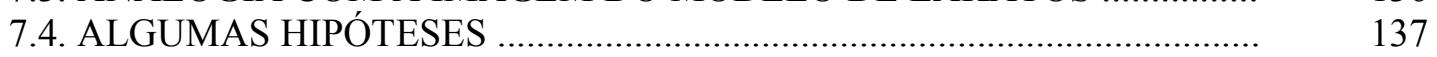

7.5.AMPLIAÇÃO DA ANALOGIA COM O MODELO DE LAKATOS: A

METODOLOGIA DOS PROGRAMAS DE PESQUISA CIENTÍFICA E O

MODELO DE PRODUÇÃO E SUSTENTAÇÃO DA DOCÊNCIA ................... 141

7.6. RELACIONANDO O MODELO DA PRODUÇÃO E SUSTENTAÇÃO

DOCENTE COM O REAL, SIMBÓLICO E IMAGINÁRIO ............................. 149

7.7. ORGANIZAÇÃO DO MODELO NUMA SITUAÇÃO DE ENSINO...........

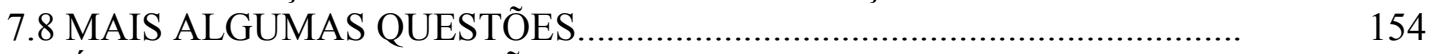

7.9 ÚLTIMAS CONSIDERAÇÕES .......................................................... 158

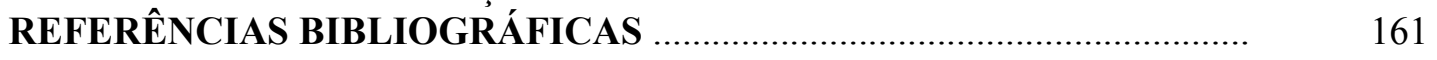

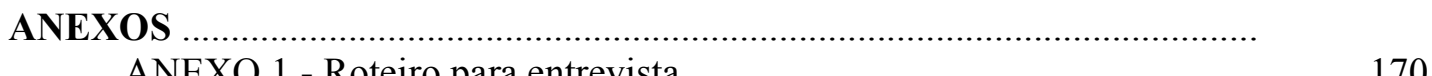

ANEXO 1 - Roteiro para entrevista …............................................ $\quad 170$

ANEXO 2 - História de Vida da Pesquisadora ..................................... 171

ANEXO 3 - História de Vida Madalena .................................................. 177

ANEXO 4 - História de Vida Maria .......................................................... 180

ANEXO 5 - História de Vida Deise ...................................................... 185

ANEXO 6 - História de Vida João …....................................................... 187

ANEXO 7 - Entrevista Madalena ............................................................ 192

ANEXO 8 - Entrevista Maria _.................................................................... 199

ANEXO 9 - Entrevista Deise ............................................................... 204

ANEXO 10 - Entrevista João .............................................................. 206 


\section{INTRODUÇÃO}

\subsection{CONSIDERAÇÕES INICIAIS}

Quando concluí a dissertação de Mestrado, em 2001, pude constatar as mudanças que sua elaboração foi capaz de promover em minha vida pessoal, pois a possibilidade de conviver com os mais diferentes referenciais e fazer a leitura, através deles, das situações da prática, me possibilitou uma nova consciência sobre o que acontecia na sala de aula. A minha entrada na pesquisa aconteceu, muito provavelmente, pelos mesmos motivos já relatados por outras pessoas que fizeram essa trajetória como necessidade de obtenção de conhecimentos para um aprimoramento pessoal e, ao mesmo tempo, uma tentativa de entender melhor a dinâmica que eu vivia em sala de aula como professora. Esse foi o momento a que eu me reportei muitas vezes, durante a trajetória do Mestrado, porque foi a partir dele que comecei a me questionar e, gradualmente, a desfazer todas as certezas que eu tinha adquirido em muitos anos de prática sobre a minha atuação em sala de aula e, principalmente, sobre a minha relação com o aluno.

A pesquisa foi iniciada com a proposta de um curso extra curricular, que fosse do interesse dos alunos, e que abordasse qualquer assunto de Física em um curso de Licenciatura em Matemática numa faculdade particular. Essa proposta surgiu devido ao fato de que esses alunos tinham a opção, já nessa fase do curso, de assumirem além das aulas de Matemática, também aulas de Física, já que a habilitação que recebiam ao final do curso assim o permitia e, mesmo porque, as aulas de Física sempre acabam sobrando nas Delegacias de Ensino. Isso acontece, principalmente, por dois fatores: falta de professores específicos da área e insegurança que professores formados em outras áreas, mesmo habilitados, têm de ministrar esses conteúdos. O projeto do curso que propusemos tinha o objetivo principal de amenizar o medo que esses alunos, futuros professores, tinham de assumir essas aulas de Física.

Mas como, aparentemente, já era previsto, os alunos optaram por um curso que abordasse conteúdos de Física Moderna ${ }^{1}$, pois desejavam entender o que era a teoria da relatividade. Esse curso foi ministrado em um semestre e utilizou a metodologia de pesquisa ação. O que aconteceu de marcante foi que, ao reconstruir a história desse curso e falar sobre

\footnotetext{
${ }^{1}$ Física Moderna - assunto que desperta a curiosidade da maioria das pessoas por quererem saber sobre teoria da relatividade, buracos de minhoca, viagens no tempo, super cordas, etc.
} 
a relação que se estabelecia na sala de aula, em como ele era conduzido, qual a participação dos alunos, etc., fui chamada não só a relatar, mas também refletir sobre os motivos de determinadas atitudes tomadas na sua condução e, até mesmo, na relação que estabelecia com os alunos. Isso aconteceu durante as apresentações da história dos dados ao grupo de pesquisa do qual participo na universidade. A minha reação, na ocasião, foi conseguir imediatamente racionalizar álibis para explicar o que tinha acontecido ou porque eu agia de determinada forma. Apesar das explicações o desconforto ficou e, mesmo que eu não quisesse, fui obrigada a assumir que, inconscientemente, agia daquela forma e que, portanto, não tinha controle sobre isso. $\mathrm{O}$ resultado dessas intervenções proporcionou uma mudança na direção do trabalho, que se focou então, na minha atuação. Precisei refletir sobre como os fatos ocorriam, ou não, na minha sala de aula e a admitir que, por ser como sou, as minhas ansiedades, os meus desejos e frustrações também tinham reflexos e atuavam inconscientemente na minha prática. Percebi, enquanto o curso transcorria, que eu realmente poderia ajudar aqueles alunos de alguma forma a terem outra relação com os conteúdos de Física, embora os motivos que pareciam estar agindo para que isso acontecesse não fossem os que eu imaginava.

Essa experiência me possibilitou conhecer muito do meu funcionamento como professora e a olhar de um outro ponto de vista a minha atuação que, até então, eu via como quase perfeita. Consciente disso ficou mais clara a minha implicação na escolha da questão de pesquisa que dizia respeito à criação de possibilidades de ajudá-los a assumirem aulas de Física. Ganhou muito mais sentido pois, aparentemente, estava preocupada em deixar herdeiros da excelente professora de Física que eu acreditava ter me tornado ao longo dos anos da minha prática.

O que ocasionou essa mudança, com certeza, foi a possibilidade de ser questionada pelo grupo e pelo orientador sobre os eventos, e refletir sobre eles. Ganhei com isso, porque apesar de aparentemente não identificar mudanças na minha atuação tenho, hoje, maior consciência de como ajo e nunca esqueço que vejo os bons resultados pelos olhos da minha expectativa.

A consolidação desse autoconhecimento ganhou sentido e pude me lançar em busca de respostas a outras questões subjetivas, que até então eu nem tinha formulado. Esse envolvimento com a subjetividade, e com a pesquisa, proporcionou uma nova questão a ser investigada no Doutorado que dizia respeito a alçar um olhar sobre as queixas que os professores fazem da sua profissão e que hoje são amplificadas nas vozes dos estudiosos da Educação, da mídia e, principalmente, entre os próprios pares. Sendo que o resultado dessa 
situação é um grande desprestígio, uma certa paralisação e uma culpabilização pelo que dá errado.

Imbuída da minha crença pessoal nos bons resultados de se estudar as relações da escola pelos aspectos subjetivos que a permeiam, me propus a questionar o fato de que as pessoas continuam se tornando professoras apesar de todas as queixas que sejam capazes de elaborar e da nuvem negra que paira no imaginário das pessoas. Portanto, fez todo o sentido nos questionarmos sobre: O que poderia ainda estar sustentando-as na profissão?

Outra pergunta que me fiz insistentemente durante a realização deste trabalho, foi quanto a necessidade, ou não, de que a minha História de Vida fizesse parte dos dados. Baseada na relação que estabeleci com a pesquisa durante o Mestrado, em determinado momento, tive certeza de que sim, pois, à medida que fui dando corpo ao relato, ou seja, quando fiz considerações sobre o fato de que a problemática da pesquisa surge de uma questão que diz respeito à minha própria prática; e que todas as escolhas que fiz sobre a metodologia, dados e, até mesmo, sobre a interpretação, estavam, inegavelmente, de alguma forma, recortados e orientados pelo meu olhar, pude inferir que também estou atravessada pelo problema da pesquisa. Portanto, considero que a minha história também pode ser vista como elemento que me autoriza a entrar nesse contexto das Histórias de Vida dos outros personagens, já que estou tão implicada em responder à pergunta de pesquisa quanto os pesquisados.

Apesar de que essa exposição identificada não seja das coisas mais agradáveis, teve o objetivo, também, de me colocar solidária e, ao mesmo tempo, trazer à tona todos os dados possíveis, já que sempre posso retomar minha história para confrontação de dados ou obtenção de algum esclarecimento.

Diante disso, nada mais justo que também fizesse esse exercício, contando os aspectos de minha história, assim como dos pesquisados, que pareceram, capazes de mapear o meu caminho e decisões em relação à permanência na docência. Esses aspectos de minha História de Vida, que apresentam ressonâncias ou discordâncias com as Histórias de Vida sobre as quais me debrucei, serão retomados nas conclusões finais. A íntegra desses textos pode ser encontrada identificada nos respectivos anexos.

Não posso perder de vista que todas essas situações da minha vida, boas ou não, que geraram afetos, ódios, inseguranças ou manifestações motivadas por impulsos eventuais, se tornaram o que invisivelmente me conduz nessa busca de respostas. Inconscientemente todos esses fantasmas estarão, para sempre, me conduzindo no cotidiano da minha sala de aula. 


\subsection{PROBLEMÁTICA DA INVESTIGAÇÃO}

Sabemos que, nos dias atuais, ser professor representa, cada vez mais, um grande desafio, pois os professores têm que lidar não só com os saberes da sala de aula, mas, também, com as tecnologias e a complexidade social do momento. Podemos até supor que o professor, hoje, vivencie um cenário mais promissor para o desempenho de sua vocação, já que pode lançar mão de modernos modelos teóricos e estratégias que podem auxiliar a sua atuação em sala de aula. As teorias de aprendizagem, os métodos de pesquisa, a inter-relação dos conteúdos com áreas que pareciam pouco relevantes para a aprendizagem evoluíram e ampliaram fronteiras. Atualmente se fala nas contribuições para aprendizagem, das inteligências múltiplas ${ }^{2}$, do discurso do professor, das concepções prévias ${ }^{3}$ que os alunos trazem para a sala de aula, das visões que o professor tem do que é ensinar a sua disciplina, dos esquemas mentais que o aluno elabora para entender algo e, até mesmo, das hipóteses que a Psicanálise pode fornecer na tentativa de iluminar a relação subjetiva entre os envolvidos: professor, aluno, instituição e sociedade nas suas queixas e angústias (MRECH, 1999).

Analisando a profissão e a profissionalização docente atual, Nóvoa (1995) nos diz que as rápidas transformações sociais, políticas e econômicas, que acontecem de forma acelerada no mundo e que atingiram o processo educativo colocam o professor numa situação de malestar. Vários são os motivos, mas os que mais pesam são o fato de que a educação já não pode prometer um futuro melhor, além da própria degradação da imagem do professor. Nóvoa (1995) continua dizendo que, devido a essas mudanças, foram aumentadas as responsabilidades do professor que tem que atuar contornando problemas para os quais não se sente preparado.

Pimenta (1999) pondera que o professor é desvalorizado porque ainda é considerado como um técnico que apenas reproduz conhecimento. Um novo olhar seria considerá-lo um mediador nos processos constitutivos da cidadania dos alunos, no sentido de superar as desigualdades escolares. Para obter algum sucesso nessa empreitada seria necessário repensar a formação inicial e contínua dos professores, analisando as práticas pedagógicas e docentes que os formam e que só podem ser encenadas dentro da instituição e da sala de aula. A formação inicial, que utiliza um currículo formal com atividades de estágios muito distante da

\footnotetext{
${ }^{2}$ GARDNER, Howard. Inteligências Múltiplas: a Teoria na Prática. Porto Alegre: Artes Médicas, 1995.

${ }^{3}$ SANTOS, M. E. Mudança conceptual na sala de aula: um desafio pedagógico. Lisboa: Livros Horizonte Ltda, 1991.
} 
realidade da sala de aula, pouco contribui para amenizar esse quadro. Durante a formação inicial, a socialização do professor aprendiz com os outros professores se dá no interior da instituição, que deve ser a articuladora desses momentos de formação e exercício inicial da atividade de ensino, ou seja, há que existir uma integração entre teoria e prática como verificamos nos trabalhos de Lüdke (1996a, 1996b e 1998).

Segundo Couto (1998), a defasagem entre a teoria e a prática em algumas disciplinas, e o despreparo para lidar com alunos que necessitam de apoio especial, fazem com que o estágio pedagógico seja ainda tomado como a referência principal de formação do professor iniciante. Em sua tese de Doutorado, apregoa a necessidade de uma mudança na concepção das licenciaturas em ensino, tornando-as como parte de um projeto de formação da própria instituição, oportunizando a criação de uma rede de apoio aos jovens professores em início de carreira.

A formação continuada também não tem conseguido trazer o professor para uma situação mais confortável porque, mesmo o investimento pessoal no conhecimento, não garante sucesso durante a atuação com os problemas reais da sala de aula, da escola e da comunidade.

As considerações de Azanha (1990) nos explicam essa impossibilidade de sucesso:

A entidade a ser objeto de atuação de uma política de melhoria do ensino é a escola. Nem se alegue que uma política de aperfeiçoamento que alcançasse todos os docentes teria êxito na melhoria da qualidade do ensino. Uma escola não é apenas um conjunto de professores. Uma escola é uma entidade social que não é mera reunião de indivíduos com diferentes papéis. [...] A questão da qualidade do ensino é, pois, uma questão institucional. São as escolas que precisam ser melhoradas. Sem este esforço institucional, o aperfeiçoamento isolado docente não garante que essa eventual melhoria do professor encontre na prática as condições propícias para uma melhoria do ensino. (AZANHA, 1990, p. 52)

Ainda podemos relatar as resistências que o professor tem em relação às mudanças em sua prática, mesmo que essas inovações teoricamente possam proporcionar uma melhoria nos processos de ensino e de aprendizagem. Segundo Freitas e Villani (2002), um dos motivos para essa resistência decorre do fato de que a prática docente é permeada por teorias, valores, concepções e crenças pessoais, os quais, muitas vezes, se apresentam inadequados ao cotidiano escolar e sobre as quais o professor não se questiona, e nem mesmo, em relação a sua própria prática.

Segundo Contreras (2001), o profissional reflexivo é justamente aquele que enfrenta as situações adversas em sala de aula, dispõe de autonomia, de técnicas de ensino e que se propõe a tomar atitudes que possam, de alguma maneira, levar a soluções satisfatórias. 
Um dos conceitos mais frutíferos que se tem hoje, para se pensar nas relações da sala de aula, é o de professor reflexivo, pois a apropriação desse conceito representou uma grande possibilidade de mudança no cenário da formação de professores a partir dos anos 1990.

Na análise de Schön (2000), seu principal formulador, a formação até então praticada não garantia ao professor responder às situações do cotidiano da sala de aula, nas quais questões complexas exigiam do professor conhecimento que fossem além dos elaborados pela ciência, cujas respostas técnicas ainda não estavam formuladas. Pimenta (2002), faz considerações sobre a reflexão, análise e problematização da prática profissional.

Assim, valorizando a experiência e a reflexão na experiência, conforme Dewey, e o conhecimento tácito, conforme Luria e Polanyi, Schön propõe uma formulação profissional baseada numa epistemologia da prática, ou seja, na valorização da prática profissional como momento de construção de conhecimento, através da reflexão, análise e problematização desta, e o reconhecimento do conhecimento tácito, presente nas soluções que os profissionais encontram em ato. (PIMENTA, 2002, p. 2).

O conhecimento que o professor atuante acredita ter, e se orgulha de carregar devido às experiências que vem adquirindo ao longo do tempo, é o saber fazer, que lhe garante estar na sala de aula e dar seqüência aos acontecimentos cotidianos, gerando uma segurança ilusória. Segundo Schön (2000) era necessário mais, era preciso que o professor fosse surpreendido pelo aluno, refletisse sobre a situação tentando compreendê-la, reformulasse o problema fazendo uma experiência para testar suas hipóteses, porque se o professor se coloca no lugar de quem sabe tudo, ao aluno só cabe o lugar de quem vai aprender e não de quem pode surpreender.

Ao conceito professor-reflexivo foram feitas inúmeras críticas e contribuições, que não impediram uma apropriação generalizada, mas que pouco se traduziram em mudanças concretas na sala de aula. Parece-nos, porém, que a fecundidade do conceito se revelou como primeira possibilidade de busca que o professor pôde empreender na direção de questionar os eventos da sala de aula e, ao mesmo tempo, se colocar como capaz de mediar esses conflitos. Isto pode, em termos ideais, ter colocado em questão a sua verdadeira aptidão e, até mesmo, as razões e os motivos que o levaram à docência.

Acreditamos que essa reflexão foi capaz, em alguns casos, de fornecer ao professor maior percepção sobre os argumentos que ele utiliza para se justificar e uma maior compreensão em relação aos seus próprios valores, atitudes e desejos, levando-o a questionar suas opções e ações na tentativa de compreender as várias facetas implícitas no processo da aprendizagem, que se desenvolve na sala de aula, e que o envolve tanto quanto o aluno. 
O processo reflexivo tentava garantir a compreensão de todas as descontinuidades que pudessem acontecer na sala de aula, mas não conseguia dar conta. A prática da sala de aula é muito mais complexa e, além de tudo, o professor se encontra dentro da instituição numa situação em que ele não se sente seguro em relação ao trabalho, não pode ser aceito totalmente pelos pares, é questionado sobre os limites que impõe ao aluno e ainda tem que ter em conta a sua falta de controle sobre as suas próprias resistências e ambigüidades, as quais também permeiam a relação da sala de aula.

Ser ouvido, para o professor, segundo Souza (2000), é de suma importância porque, ao falar sobre as suas experiências, subjazem nos seus relatos ações e reflexões que se perdem e que ele próprio, muitas vezes, não consegue detectar a importância. O que ocorre, principalmente, porque os professores constroem seu papel, sua identidade, no contexto da instituição escolar em que atuam, que também tem sua história, sua cultura, suas práticas e rotinas já estabelecidas, exigindo dos professores uma adequação às suas expectativas.

Larrosa (1994) nos diz que, para a constituição de uma experiência de si ou de subjetivação, o sujeito vai depender de como a comunicação acontece, associada a um processo de ouvir, de contar, de ler, de inventar e reinventar histórias, ou seja, de participar ativamente da experiência cultural. Ainda segundo o autor:

Toda cultura deve transmitir um certo repertório de modos de experiência de si, e todo novo membro de uma cultura deve aprender a ser pessoa em alguma das modalidades incluídas nesse repertório. [Portanto] em qualquer caso, é como se a educação, além de construir e transmitir uma experiência objetiva do mundo exterior construísse e transmitisse também a experiência que as pessoas têm de si mesmas e dos outros como sujeitos. (LARROSA, 1994, p. 45).

Ser professor carrega também, no seu bojo, a História de Vida do próprio professor em que, com certeza, estão os fantasmas de seus professores do passado, que, inconscientemente, balizam o seu percurso e suas ações. Sobre a situação dúbia que o professor vive quando ainda é aluno na formação inicial e virá a ser professor, encontramos considerações subjetivas muito bem colocadas por Villani (1999):

Ele virou 'professor'. Seu antigo professor pode dar conselhos, mas quem decide o que fazer com o conhecimento parcialmente satisfatório deve ser o próprio sujeito, pois as conseqüências de suas opções devem ser por ele assumidas. $\mathrm{O}$ elemento essencial dessa experiência é aceitar a insatisfação que, junto com a vontade de saber, mantém o sujeito amarrado ao problema; ela difere tanto da frustração de não ter conseguido esclarecer o problema (atitude que leva a abandonar a procura), quando da ilusão de terem encontrado tudo aquilo que era significativo (atitude que também leva a abandonar a procura por razões opostas). Sem essa experiência o futuro professor não será capaz de induzir e sustentar o processo dos seus alunos rumo a reconhecer e enfrentar sua insatisfação e assumir uma 
responsabilidade frente ao conhecimento adquirido e finalmente produzido. (ibid., p. 17).

Segundo Nóvoa (1995), a pesquisa da História de Vida do professor pode ajudar a entender o que acontece na sala de aula, já que é impossível separar o pessoal do profissional, em uma profissão que lida com as relações humanas. Portanto, nos parece ganhar mais sentido a tentativa de entender quem é o professor, as experiências que ele vivenciou a partir de sua própria história e que balizaram suas escolhas, porque nelas, expostas ou veladas, estarão as suas razões.

Há medidas que é urgente tomar, no exterior e interior da profissão docente. As abordagens (auto) biográficas podem ajudar a compreender melhor as encruzilhadas em que se encontram actualmente os professores e a delinear uma profissionalidade baseada em novas práticas de investigação,de ação e de formação (NÓVOA, 1995, p. 8).

As pesquisas em História de Vida de professores têm sido baseadas em relatos pessoais de pesquisados sob uma perspectiva sócio-histórica. O que acontece é o rememorar e recontar da sua atuação levando em conta os seus objetivos pessoais e profissionais que darão sentido a sua prática, tornando-a autoformativa. Segundo Moita (1995), “A abordagem biográfica é mais do que uma metodologia coerente com a problemática construída. É a via de acesso à sua exploração”. (MOITA, 1995, p. 117). Essa prática de investigação, que usa a narrativa, é justificada por Ben-Peretz (1995) que diz que a sua importância deriva do fato de:

[...] o homem ser um potencial contador de história que, individual ou socialmente, vivencia uma história de vida. O estudo da narrativa é, por assim dizer, o estudo do modo como o ser humano 'sente' o mundo. Esta noção geral traduz a opinião de que a educação é a construção e a reconstrução de histórias pessoais e sociais; professores e alunos são os contadores de histórias e personagens das suas próprias histórias e das histórias dos outros. (BEN-PERETZ, 1995, p. 201).

Existem aspectos pessoais da prática do professor que podem vir à tona, quando ele conta histórias sobre a sua atuação, sobre os problemas da profissão e, até mesmo, sobre como ele se comporta, tentando atender o conceito de professor reflexivo. Entretanto, enquanto conta, existem fatores dos quais ele não se apercebe, mas que podem estar interferindo igualmente na situação. No trabalho de Ferreira (2001), encontramos uma experiência que foi capaz de gerar uma reflexão mais profunda sobre a relação da sala de aula, pois, o professor estudado, olhou para a sua prática a partir da sua própria história e se deu conta de que seus sonhos, desejos, crenças e medos também estavam em jogo. Essa percepção foi necessária para que fosse feita uma reflexão eficiente sobre sua prática, no sentido de tentar entender o que realmente estava acontecendo na sua sala de aula. A maior contribuição desse trabalho foi 
apontar para alguns elementos importantes da vida do professor como a escolha da profissão, as suas motivações inconscientes e o reconhecimento de suas reações e frustrações subjetivas, que não podem ser separadas da sua atuação. As explicações mais prováveis para os eventos não são, com certeza, somente aquelas que racionalizamos e trazemos à tona imediatamente nas nossas reflexões. Na realidade, são mais subjetivas que isto e, estão marcadas pela singularidade do sujeito.

As funções que a sociedade hoje atribui aos professores são diferentes do que foi no passado. Então, é muito difícil para o professor construir sua identidade baseada numa história de valores que não encontra mais. Ele tem que se reconstruir numa nova lei de mercado e de habilidades que nunca vão se satisfazer e que irão, a todo o momento, criar novos padrões, solicitações e competências para a atividade docente. Ou seja, o professor nunca se sentirá completamente seguro em nenhum lugar. Estará sempre em dívida. Não só terá dívida com o conhecimento que o impele a reproduzi-lo, mas também com a instituição escolar e com a sociedade que não têm clareza sobre qual é o seu novo papel na transmissão desse conhecimento.

Se pensarmos nas muitas questões que o professor enfrenta atualmente, podemos enumerar algumas como a ausência de estímulo profissional, que acaba gerando uma falta de motivação para efetuar mudanças possíveis na sua atuação; as exigências da família em relação ao professor e ao que ela acredita ser papel da escola; as dificuldades na elaboração de trabalhos interdisciplinares e de lidar com os alunos problema. Como se não bastasse, o professor ainda não é bem remunerado e, por isso, precisa trabalhar em mais de um estabelecimento de ensino. Quanto a esse aspecto podemos dizer que os cursos de educação continuada acabam perdendo o seu caráter formador para se tornar apenas um meio do professor conseguir melhores qualificações na obtenção de um salário melhor em instituições particulares de ensino.

Após a configuração deste quadro, que contempla os maiores impasses da profissão docente na atualidade, podemos dizer que, mesmo assim, por diferentes motivos, as pessoas continuam sendo professoras e, é claro, que continuam fazendo queixas sobre inúmeros fatores que seriam necessários para atingirem melhores condições no exercício da profissão.

Contudo, quaisquer que sejam, esses obstáculos não impedem que o professor permaneça em sala de aula. Mesmo que, em alguns casos, seja uma profíssão assumida ao acaso, ou até mesmo, iniciada para uma complementação salarial. O que podemos perceber, por trás de todos esses problemas e discursos, é uma satisfação não revelada, alguma coisa que o mantém preso, por bem ou por mal, à prática da sala de aula. 
Buscamos, com essa pesquisa, encontrar alguma ressonância dos dizeres dos nossos pesquisados, que também são professores em exercício, com os de outros professores, sobre os motivos que os mantém em sala de aula. Esperamos ainda dar a conhecer ao professor iniciante, aspectos que vêm junto com a prática e que estarão permeando as relações dentro da sala de aula. O que esperamos também é que, a partir desse conhecimento subjetivo sobre as razões da sua escolha pela docência e o olhar sobre os motivos que os mantêm, os professores em exercício possam reencontrar o significado de suas escolhas e se inserir na profissão de uma maneira talvez mais legítima, e, com maior chance de obtenção de efeitos e resultados positivos.

Ao narrar a sua experiência no ensino, os professores explicitam suas intuições baseados na sua experiência pessoal. Reestruturam os eventos de sua trajetória e a reflexão faz com que esses eventos sejam atualizados e reintegrados na sua história. É acreditando nessa reflexão e integração da prática e da própria história, que estamos apostando nas Histórias de Vida como metodologia para obtermos informações sobre o exercício de ser professor e ter acesso às considerações que venham a tecer sobre a sua escolha e manutenção profissional. 


\section{METODOLOGIA DA PESQUISA}

\subsection{HISTÓRIA DE VIDA E NARRATIVA}

A Narrativa é um caminho investigativo que pode ser utilizado como um instrumento de coleta de dados e que é capaz de provocar transformação na forma como as pessoas compreendem a si próprias e aos outros, já que ser protagonista da própria História de Vida implica em mergulhar em si mesmo e, ao mesmo tempo, conseguir distanciamento na tentativa de explicar as próprias experiências. Segundo Cunha (1998, p. 40), este é "um processo profundamente emancipatório em que o sujeito aprende a produzir sua própria formação, auto determinando a sua trajetória".

\section{Segundo Larrosa (1999)}

[...] o sentido do que somos depende das histórias que contamos a nós mesmos [...], em particular das construções narrativas nas quais cada um de nós é, ao mesmo tempo, o autor, o narrador e o personagem principal [...] Talvez [...] não sejamos outra coisa que um modo particular de contarmos o que somos. (ibid., p. 22)

A formação de uma identidade com a carreira de professor pode ser percebida, em parte, na trajetória fornecida pelo indivíduo durante a construção da narrativa da sua História de Vida pessoal quando nos conta dos saberes acadêmicos que foram adquiridos na escola, da sua prática da sala de aula, da busca de crescimento profissional na carreira docente e, ainda, das relações com a instituição em que trabalha.

As narrativas dos sujeitos são a sua representação da realidade e, como tal, estão prenhes de significados e reinterpretações [...] $O$ fato da pessoa destacar situações, suprimir episódios, reforçar influências, negar etapas, lembrar e esquecer, tem muitos significados e estas aparentes contradições podem ser exploradas (CUNHA, 1998, p. 38).

A biografia, utilizada como um discurso narrado pelo sujeito autor e protagonista, cria um espaço de reinvenção e identificação.

Ricoeur (1997) nos diz que o sujeito é, ao mesmo tempo, leitor e escritor de sua própria História de Vida porque ele não pára nunca de dar-se novos sentidos a partir de todas as histórias que pode contar sobre si; e que a identidade narrativa não é uma identidade estável porque podemos montar várias situações, e contar muitas histórias, sobre os mesmos incidentes.

Conforme encontramos em Brandão (1994), a História de Vida, como uma metodologia de natureza qualitativa, tem seu foco dirigido à experiência humana e parte do 
pressuposto de que os seres humanos são contadores de histórias: contam como conduzem social e individualmente suas vidas. A História de Vida tem sido utilizada em inúmeros trabalhos científicos de diferentes áreas e podemos citar os desenvolvidos por Dias (1997), Santi (1993), Bueno (1996), Dobbeck (2000), Freitas (1998) e Josso (1999), em que preconizam que, partindo da História de Vida, o protagonista tem oportunidade de refletir, indagar, buscar no passado a relação com os movimentos que influenciaram o presente, principalmente antes e depois da chegada efetiva ao exercício profissional.

A memória é um processo individual e, segundo Portelli (1997), ocorre em um meio social dinâmico levando em conta os instrumentos criados e compartilhados socialmente. Isto faz com que, de algum modo, as recordações possam ser semelhantes, contraditórias ou sobrepostas, mas, em hipótese alguma, as lembranças de duas pessoas são exatamente iguais.

A proposta de trabalhar na produção e análise de relatos autobiográficos da formação intelectual, que são histórias que a pessoa constrói para dizer de si próprio e a si próprio, nos parece constituir um recurso metodológico com um potencial de compreensão bastante fecundo. Esses relatos, provavelmente, favorecem novas visões e dimensões das experiências de vida ocorridas durante a formação e atuação profisssional, ajudando o indivíduo a entender melhor suas escolhas e, assim, repensar e reavaliar suas ações passadas e futuras.

Souza et al (1994) nos mostram que as potencialidades do trabalho com relatos de formação possibilitam uma reflexão sobre o movimento feito pelo individuo em relação ao conhecimento, à escola, à leitura e à escrita, permitindo reinterpretações de si próprio.

Por essas razões elegemos o método biográfico das Histórias de Vida como coletor de dados, por considerá-lo o mais apropriado na tentativa de nos aproximarmos do imaginário construído pelos professores em relação à escola, ao exercício da profissão e à docência. Dessa forma, pretendemos investigar de que maneira o professor constituiu-se em termos pessoais e profissionais e, principalmente, quais os mecanismos o mantêm na profissão.

O trabalho com a História de Vida também envolve o reconhecimento da subjetividade e da individualidade que o professor construiu socialmente, pois necessariamente ele tem que fazer relações com o passado, possibilitando uma movimentação dos significados dados aos fatos que são lembrados, e estes podem modificar-se dependendo do momento em que estão sendo revisitados pela memória.

Pollak (1989), ao se referir à potencialidade das Histórias de Vida pondera que:

[...] por definição, reconstrução a posteriori, a história de vida ordena os acontecimentos que balizaram uma existência. Além disso, ao contarmos nossa vida, em geral tentamos estabelecer uma certa coerência por meio de laços lógicos entre acontecimentos chaves (que aparecem então de uma 
forma cada vez mais solidificada e estereotipada) e de uma continuidade, resultante da ordenação cronológica. Através deste trabalho de reconstrução de si mesmo o indivíduo tende a definir seu lugar social e suas relações com os outros. (POLLAK, 1989, p. 11).

Na nossa coleta de dados utilizamos a autobiografia - mais especificamente memoriais de formação que relatam histórias sobre tornar-se professor - e mantivemos uma linha de diálogo reflexiva com os pesquisados para discussão de suas Histórias de Vida e dos significados atribuídos por eles e pela pesquisadora. Os próprios participantes elegeram quais histórias deveriam ser contadas e, nesse exercício de escrita e reescrita, a contaram endereçada para alguém. O esforço residiu na expectativa de que fosse incorporado na narrativa do professor, o sujeito e sua subjetividade, dando oportunidade a que ele trouxesse à tona interpretações sobre a sua situação de ser professor. Ou seja, nos preocupamos em tentar desvendar o imaginário dos docentes quanto ao ser professor e, com isto, foi oportunizada a reconstrução de uma compreensão pessoal da relação entre sua própria história e sua escolha profissional.

Carvalho (2003) chama atenção para o fato de que a análise autobiográfica é uma atividade comunicativa, já que o pesquisado deve contar sua História de Vida descrevendo a situação, argumentando sobre problemas significativos que sejam recorrentes, e como ele se relaciona com esses fatos. Quando a pesquisadora trabalha na interpretação desse material ela também se torna uma interlocutora, integrando o circuito da produção do conhecimento. Esse fator não deve ser deixado de lado, já que ela é quem escolhe, significa e ressignifica os dados que emergem dos relatos de vida dos professores.

Couto (1998) nos esclarece sobre mais alguns elementos a serem considerados durante a coleta de dados:

A narrativa, como metodologia de investigação, implica uma negociação de poder e representa de algum modo, uma intrusão pessoal na vida de outra pessoa. Não se trata de uma batalha pessoal, mas é um processo ontológico, porque nos somos, pelo menos parcialmente, constituídos pelas histórias que contamos aos outros e a nós mesmos acerca das experiências que vamos tendo. Decorrente dessa visão existe na narrativa uma conotação narcisista que tem ver a com a exposição do eu. (COUTO, 1998, p. 122).

As Histórias de Vida, levando em conta seus usos, podem ser utilizadas tanto para a obtenção de dados como para uma intervenção de ensino. Segundo Ferreira e Amado (2001):

Em nosso entender, a história oral, como todas as metodologias, apenas estabelece e ordena procedimentos de trabalho - tais como os diversos, tipos de entrevistas e as implicações de cada um deles para a pesquisa, as várias possibilidades de transcrição de depoimentos, suas vantagens e desvantagens, as diferentes maneiras de o historiador relacionar-se com seus 
entrevistados e as influências disso sobre seu trabalho - funcionando como ponte entre teoria e prática. (FERREIRA; AMADO, 2001, p. 16).

Continuando as considerações destes autores sobre as divergências entre os que postulam a história oral como disciplina, e não como metodologia, uma delas está no fato deles "reconhecerem na história oral uma área de estudos com objeto próprio e capacidade (como fazem todas as disciplinas) de gerar no seu interior soluções teóricas para as questões surgidas na prática”. (FERREIRA; AMADO, 2001, p. 16).

No nosso caso, a História de Vida não foi utilizada como uma intervenção de ensino, mas como coleta de dados e se constituiu num meio que possibilitou o estudo das situações declaradas pelo professor sobre a sua profissionalização.

A metodologia de História de Vida utilizada foi, ainda, pautada, em parte, por algumas considerações feitas por Franco (1996), que chama a atenção para a 'dinâmica compreensiva', permitindo ao pesquisado não só contar a sua história, mas também reconstruí-la. Afinal, essa nova condição de reconstrutor permite uma “...tomada de consciência frente à totalidade de impressões fragmentadas de seu passado. Deve-se dar espaço para o sujeito apropriar-se dessa temporalidade recomposta".

Então, podemos crer que essa dinâmica proposta por Franco (1996) foi contemplada a partir das diversas idas e vindas do texto da narrativa entre a pesquisadora e os professores. A cada devolução do texto pela pesquisadora, o narrador recebia sua história com questionamentos sobre as informações que não foram contempladas ou, ainda, lhe era solicitado que esclarecesse algumas situações. Durante essa interação dialógica, que foi feita por correio eletrônico, os professores demonstraram envolvimento com a proposta e se colocaram em ação para pensar e repensar sua trajetória pessoal e profissional e, principalmente, seus motivos. 


\subsection{HISTÓRIA DOS DADOS}

Para responder a nossa questão de pesquisa acompanhamos duas disciplinas e cinco salas de aula. A disciplina de Metodologia de Ensino de Ciências de uma universidade pública do interior do Estado de São Paulo nos permitiu o acompanhamento de duas turmas; uma do curso regular de Pedagogia, com alunos que estudavam no diurno e que ainda não atuavam como professores; a segunda dos alunos de Pedagogia de um curso noturno, que foi criado para atender exclusivamente professores em exercício, ou seja, professores que já tinham a formação de Magistério, correspondente ao ensino médio, mas que estavam habilitados para dar aulas de $1^{\mathrm{a}}$ a $4^{\mathrm{a}}$ séries e ensino pré-escolar e que, de fato, exerciam a profissão na rede pública. A segunda disciplina foi a de Introdução à Pesquisa em Ensino de Ciências de um curso de pós-graduação em outra universidade pública, na cidade de São Paulo, em que estudavam professores que já tinham Licenciatura, já estavam em sala de aula e agora faziam Mestrado ou Doutorado, ou se candidatavam ao ingresso.

Em todas as disciplinas o procedimento da coleta de dados foi o mesmo, o que resultou em interação com 99 Histórias de Vida, 47 da disciplina da Pedagogia e 52 da pósgraduação. Efetuamos uma primeira análise, como resultado das leituras que fazíamos, para manter a interação dialógica com o pesquisado sobre o contar e o recontar sua história, não perdendo o foco em nossa questão de pesquisa. E o resultado dessa organização nos mostrou que os alunos que ainda não tinham assumido aulas, que eram da Pedagogia diurno, não tinham uma ancoragem no seu discurso no que se referia a situações cotidianas que, de certa

forma, falassem sobre relações da sala de aula que pudessem ajudar a entender sobre a permanência na profissão.

Após essa primeira delimitação, ficamos com as Histórias de Vida dos professores em exercício da Pedagogia e da disciplina de pós-graduação, já que todos estavam em sala de aula e, de certa forma, reafirmavam essa posição, voltando como alunos, para obter uma melhor especialização.

Durante as análises seguintes, utilizando categorias empíricas criadas, e outras baseadas na Análise do Discurso com o conceito de Ethos estabelecido por Maingueneau (2005), achamos necessário fazer uma segunda delimitação daqueles que seriam os dados. Porque percebemos que, apesar dos professores do curso de Pedagogia responderem às categorias da mesma maneira que os outros docentes, existia algo de muito específico nas suas respostas. Não podemos negar que a relação que o professor estabelece com crianças 
nessa fase de inicio de escolarização mostra uma exacerbação de sentimentos, e de situações de cuidados. O que tínhamos como elementos resultantes dessa análise nos diziam que esses professores, quando falam da sua relação com os alunos, especificam claramente: os cuidados físicos que têm com eles; as declarações de amor que recebem; a gratificação de ver a evolução quase milagrosa em termos da fala e da escrita; as atitudes maternalistas de separar brigas, passar sermões; limpar narizes e muitas vezes trocar fraldas.

Apesar dessas situações fazerem sentido, nas categorias de análise que elaboramos, optamos, devido à natureza exacerbada dessas relações, em nos centrar nos professores que estão na disciplina de pós-graduação. As relações que o professor de ensino médio estabelece com seus alunos apresentam outras sutilezas nas interpretações que elaboramos nesse trabalho, para esse grupo de professores.

Achamos relevante ainda esclarecer dois fatores: o primeiro diz respeito ao fato de os nossos pesquisados, da disciplina de pós-graduação, serem professores em situação ideal, no aspecto de que, se existir a possibilidade de responder a questão da permanência na profissão, eles podem ser portadores dos dados mais promissores; o segundo é o fato de que esses professores, todos eles, são professores de Física, Química ou Biologia, o que pode gerar a idéia de que alguma especificidade da área pode afetar os dados. Esclarecemos, entretanto, que nessa fase, devido às pré-análises que elaboramos, já tínhamos como certo a natureza subjetiva que envolvia os discursos, as considerações e sentimentos em relação a profissão. Mesmo porque, quando os professores contaram sobre a sua vida, escolha profissional e prática docente, apesar de declararem como imprescindível a obtenção da formação científica, não estabeleceram nenhum vinculo no seu discurso entre manutenção e especificidade da profissão. Por isso nos sentimos seguros em acreditar que aqueles que se constituíram nos dados que utilizamos, podem ser capazes de inferir os resultados a que chegamos.

Após o estabelecimento de qual o universo de Histórias de Vida que iríamos trabalhar, que foram da disciplina de pós-graduação, nos empenhamos em fazer um relato, o mais fiel e detalhado possível, sobre as condições existentes durante a obtenção dos dados. Para isso, descreveremos inicialmente a disciplina e seus objetivos e, a seguir, tentaremos construir uma imagem do clima existente na sala de aula retratando algumas situações marcantes. Após montar o cenário em que foram obtidos os dados, explicamos como se realizou efetivamente essa coleta. Argumentamos sobre a necessidade de uma complementação e, finalmente, esclarecemos, os critérios utilizados na escolha daqueles que seriam os dados.

A coleta de dados, que utilizaremos, ocorreu na disciplina Metodologia de Pesquisa em Ensino, de um curso de pós-graduação, porque acreditávamos que professores que 
vivenciavam essa situação de reafirmação dos votos na escolha profissional, fossem capazes de nos fornecer elementos mais seguros sobre as razões da escolha e, principalmente, da permanência na docência. Sabemos que estamos lidando com uma parcela privilegiada de professores, mas acreditamos que provavelmente todos os outros, que estão na profissão, devem estar se mantendo nessa situação pelos mesmos motivos.

Esclarecemos que os nomes de pessoas, instituições e locais foram trocados com o objetivo de preservar a identidade dos pesquisados.

\subsubsection{Primeira fase da coleta de dados}

A coleta de dados escolhida, para a pesquisa, foi a realizada durante o primeiro semestre de 2004, numa disciplina ministrada numa universidade pública na cidade de São Paulo, para alunos da Pós Graduação em Ensino de Ciências, pelo professor Lupo ${ }^{4}$. A disciplina buscava atender inicialmente os alunos ingressantes na pós-graduação interunidades ${ }^{5}$ (cursos de Física, Química). Devido à grande procura desta disciplina pelos alunos regulares e também pelos alunos especiais ${ }^{6}$, foram montadas três turmas no período vespertino: na segunda, na terça e na quarta-feira. A pesquisadora acompanhou as três turmas, que serão referidas por T1, T2, T3, com 18, 14 e 20 alunos, respectivamente. Nessa disciplina, a escrita de História de Vida foi proposta como atividade obrigatória para os professores, porque fazia parte dos instrumentos de avaliação final. Então, de um jeito ou de outro, todos os alunos elaboraram a sua História de Vida, possibilitando, após algumas desistências no desenrolar da disciplina, uma interação da pesquisadora com 52 professores e suas narrativas.

Um dos objetivos principais dessa disciplina era a elaboração, pelo aluno, de um Projeto de Pesquisa de Mestrado ou Doutorado na área de Ensino de Ciências. O que se pretendeu foi fornecer elementos para que esses ingressantes, ou futuros ingressantes, pudessem elaborar um projeto coerente, metodologicamente correto e passível de ser realizado.

\footnotetext{
${ }^{4}$ Nome fictício.

${ }^{5}$ Interunidades. Programa de pós-graduação que envolve os cursos de Física e Química de uma universidade pública.

${ }^{6}$ Alunos especiais. São considerados alunos especiais os indivíduos que não estão regularmente matriculados na disciplina, mas que, assim mesmo, são autorizados a cursá-la. Eventualmente, após o ingresso como aluno regular, poderá utilizar os créditos atribuídos à disciplina.
} 
Em cada turma estavam presentes o professor Lupo, o monitor e a pesquisadora. Apesar de os três estarem envolvidos com a realização da disciplina, a coleta de dados teve ainda o objetivo de responder algumas questões do professor Lupo, fornecendo elementos para a pesquisa do monitor da disciplina e também da pesquisadora.

O professor Lupo ministrava essa disciplina pela segunda vez e estava preocupado em entender uma incoerência ocorrida na sua primeira experiência. Os alunos, naquela ocasião, declararam um aproveitamento ótimo do curso, mas apresentaram, ao final da disciplina, produções muito abaixo da expectativa. Então, o professor Lupo, com a pretensão de obter mais elementos que pudessem ajudá-lo a compreender esses deslizes e mais as possíveis contribuições da disciplina para a formação do pesquisador, convidou mais dois pesquisadores, nesse caso, o monitor e a própria pesquisadora, a estarem na sala de aula efetuando registros, para uma posterior discussão dos eventos relevantes que ajudassem nessa compreensão.

O monitor foi encarregado de prestar assistência aos alunos em cada etapa da elaboração do projeto de pesquisa, fazer o máximo possível de leituras, correções, sugestões e devolução do texto para as eventuais modificações. Foi, ainda, criada a oportunidade para que o aluno apresentasse o seu projeto em dois momentos diferentes durante o semestre para os colegas de sala de aula, com o objetivo de que todos pudessem colaborar com sugestões ou perguntas que talvez o próprio elaborador ainda não se tivesse feito.

A pesquisadora faria o diálogo com as Histórias de Vida dos alunos e ainda obteria informações sobre as expectativas e dificuldades com a disciplina e o Mestrado. Ou seja, o professor, dessa vez, estava preocupado não só com o fato do resultado ser bom, mas também em entender o que realmente tinha acontecido durante o processo.

Em nossa visão, a disciplina exigiu uma grande dedicação dos alunos, pois tinham que ler uma bibliografia extensa dividida entre seminários e leituras além de um grande número de atividades a serem feitas ou apresentadas. Para obtenção do conceito final o aluno teria que cumprir as seguintes etapas: apresentar um seminário, conduzir a discussão de um texto lido e preparado em casa; fazer, durante o curso, um diário de aprendizagem em que deveria relatar a sua interação com a disciplina e os colegas, destacando os elementos que contribuíram de maneira efetiva para a consecução do seu projeto de pesquisa; realizar, transcrever e categorizar uma entrevista gravada, feita por ele; elaborar sua História de Vida tendo como foco a criação de um relato em que aparecessem elementos de sua escolarização até a escolha profissional e responder as questões colocadas pela pesquisadora não só sobre a narrativa da 
sua História de Vida, mas também sobre a dinâmica do curso; e, finalmente, a atividade principal e produto do curso: a elaboração do projeto de pesquisa.

Durante a escrita da História de Vida, a interação com a pesquisadora foi dialógica via correio eletrônico com o uso de arquivo anexado e, apesar de fazer parte da avaliação da disciplina, o que se levou em conta, efetivamente, foi a disposição da pessoa em se envolver com a narrativa de sua história.

Os alunos dessa disciplina eram todos licenciados em Física, Química ou Biologia, já exerciam a profissão e, na maioria dos casos, eram alunos regulares do programa de pósgraduação. Eram assíduos, atentos às aulas e se preocupavam com o cumprimento das atividades solicitadas. Desejavam manter uma boa impressão, para o professor, monitor e pesquisadora, sobre o seu interesse nos conteúdos e o seu possível desempenho na disciplina. Apesar disso, alguns projetos apresentaram dificuldades porque alguns dos alunos demoraram a compreender a diferença entre projeto de pesquisa e projeto de ensino, como exemplificamos com as anotações do monitor.

A aluna enviou três vezes o seu projeto, apesar de minhas observações; ele (o projeto) ainda retrata atividades de um projeto de ensino. (relatório do monitor da disciplina).

Para sermos mais específicos em relação ao clima presente nas salas de aula durante a coleta de dados, conforme já dissemos, optamos por estabelecer um pequeno perfil de cada grupo de alunos, o que pode, de certa forma, trazer à tona mais elementos para a compreensão desses mesmos dados.

Na turma 1 a maioria dos alunos estava regularmente matriculada no programa de pósgraduação e se preocupava em deixar transparecer interesse e ótimo desempenho nas tarefas, apesar de que, na maior parte do tempo, mostrava uma postura individualista em sala. Esses alunos tiveram o apoio e orientação, de seus próprios orientadores do seu programa de pósgraduação, na definição de aspectos importantes do seu projeto de pesquisa. Não sabemos se, por verem alunos se saindo tão bem, alguns alunos especiais colocaram-se numa situação de impotência e declararam, muitas vezes, serem incapazes de cumprir as etapas da elaboração do seu projeto.

Esses alunos especiais relataram as suas angústias por estarem na disciplina sem saber qual assunto exatamente pesquisar e, principalmente, sem saber o que era necessário para se montar um projeto de pesquisa. Sentiram-se muito pressionados, mesmo que ninguém o tivesse feito explicitamente e, talvez pelo sucesso da maioria dos alunos, a mostrarem um bom projeto permanecendo um pouco bloqueados no seu desempenho. Evidentemente os 
alunos especiais de todas as turmas relataram dificuldades na elaboração do projeto, mas nessa turma essa angústia veio à tona muito mais vezes.

Débora ${ }^{7}$. Quando comecei a pensar no projeto descobri que não tinha nada para pesquisar. Isso foi muito ruim. Não conseguia me definir por nenhum assunto, todos os temas pareciam já abordados por alguém. Só agora depois de tanto tempo, que eu consegui direcionar meus pensamentos para um tema de pesquisa, resta ainda verificar junto ao professor se essa idéia é aceitável. Pra mim a única coisa ruim que aconteceu foi o fato de me sentir incapaz de desenvolver um projeto de pesquisa. Quando me sentei pela primeira vez para pensar, vi que não tinha nada para pesquisar e por mais que eu tentasse não conseguia definir, isso foi mesmo muito ruim. Era difícil ver os outros alunos com os projetos já encaminhados, cheios de idéias com propostas já definidas, confesso que isso me derrubou! Fiquei várias semanas achando que devia desistir, pois não teria condições de apresentar nada. Mas depois de chorar muito, descobri que só tentando é que vou descobrir se terei ou não condições de preparar o projeto. Depois de vencida essa etapa, consegui colocar no papel uma idéia para a pesquisa. Sei que o monitor fará muitas anotações, e que talvez diga: "Não é nada disso que eu quero". Só que, agora, terei uma direção para seguir porque a elaboração do projeto requer de mim muita dedicação e empenho.

Marta $^{8}$. Quando fiz o pré-Projeto, não tinha nenhuma experiência, agora penso que sei fazê-lo melhor, tenho novas idéias e sugestões da monitora, só falta reelaborálo.[...]Terminei o livro sobre as teorias de aprendizagem, que você me indicou, ele vai me ajudar bastante na reelaboração do projeto.

Ao final do semestre pudemos testemunhar a superação das dificuldades com o projeto de pesquisa, já que, em relação às outras atividades, nenhum aluno dessa turma relatou problemas. No que diz respeito à escrita da História de Vida, foi a turma que mais prontamente enviou a primeira versão e que melhor manteve a interação dialógica. Esse grupo de alunos melhorou sua integração, aparentemente, porque nessa fase, todos já tinham, de certa forma, vencido suas resistências, preocupando-se, agora, com a finalização das atividades estando, portanto, todos em igualdade de condições.

$\mathrm{Na}$ turma 2 haviam 7 alunos regulares, sendo os demais alunos especiais. Apresentavam muitas dificuldades com as tarefas, porque não conseguiam criar um clima geral de debate e interesse, qualquer que fosse o assunto. Alguns tinham características difíceis de serem negociadas, o que não contribuía para que se promovesse alguma integração.

O que mais chamou atenção, nessa turma, foram dois alunos que se destacavam muito nas discussões roubando, literalmente, a palavra. Isto, de certa forma, agradava aos demais porque fazia com que não precisassem se expor. Essa situação de não envolvimento criou um clima de insegurança muito grande em relação às tarefas, fazendo com que alguns não dessem conta, minimamente, da qualidade das atividades. O grupo, via de regra, estava distante e o debate não deslanchou de jeito nenhum.

\footnotetext{
${ }^{7}$ Débora- nome fictício utilizado para preservar a identidade do pesquisado.

${ }^{8}$ Marta- nome fictício utilizado para preservar a identidade do pesquisado.
} 
Só no final da disciplina apareceu algum movimento de integração, sendo que a finalização das tarefas pareceu tirá-los de um estado que oscilava entre a tensão e o descaso, propiciando, então, maior aproximação entre eles.

A turma 3 apresentou um ótimo entrosamento desde o inicio. As aulas eram muito dinâmicas e interessantes, devido ao envolvimento de praticamente todos os alunos nas discussões. A maioria dos alunos era oriunda do curso de Química e também cursava uma outra disciplina de pós-graduação, o que provavelmente facilitou e incrementou o seu sucesso como grupo. As pessoas se expunham muito, o tempo todo, fossem alunos regulares da pós-graduação ou não. Não tinham receio de colocar opiniões sobre os mais diferentes assuntos e situações. Alguns alunos chegaram a inovar utilizando técnicas novas de apresentação de trabalhos, que no caso, foi a proposição em forma de discussão entre dois grupos na sala. Um grupo faria a defesa do ponto de vista do autor do texto e o outro faria críticas a essa proposta, o que gerou rico debate e argumentação. Este fato, de certa forma, obrigou o restante do grupo a repensar as suas futuras apresentações e melhorar o suficiente para, quem sabe, conseguir o mesmo efeito 'boa surpresa' estampado na fisionomia do professor Lupo.

A sala tinha dois líderes que polarizavam as opiniões, tornando os debates polêmicos e difíceis de controlar e, nesses momentos, o professor Lupo utilizava suas intervenções apaziguadoras mais freqüentemente. Demonstravam muita disposição na realização das tarefas e nas tentativas de elaboração de um bom projeto de pesquisa.

Havia um aluno que também se destacava porque conseguia, com um jeito descontraído, mudar um tom agressivo ou conflituoso de eventual discussão que acontecesse na sala, talvez por ser uma pessoa que sempre conseguia criar situações engraçadas.

Do início ao fim, com todos os momentos polêmicos vividos, este grupo se manteve integrado e polarizado em torno dos dois lideres naturais. Esses líderes, apesar de saberem colocar de maneira muito convincente seus pontos de vista, divergiam, mas não impediam a manifestação dos demais, e quando a situação esquentava, aquele aluno já mencionado, que tinha sempre uma saída espontânea para essas ocasiões, conseguia reverter o clima para uma situação mais relaxada.

Pensando de forma geral, o que a disciplina se propôs foi a criação de um espaço em que o aluno fosse convidado a se implicar na realização de tarefas que o ajudariam a dar corpo e legitimidade ao seu projeto de pesquisa, na medida em que disponibilizou condições e elementos para que cada um fizesse escolhas plausíveis dos seus objetos de pesquisa.

Como já dissemos, os professores de nossa pesquisa eram professores em exercício que viviam a situação de desejarem ,ou de estarem, cursando uma pós-graduação. Entretanto, 
o que também vale ressaltar é que o grupo de professores pesquisados vivia uma situação muito particular que era o fato de que reconhecia e ainda prestava contas a vários interlocutores como: o monitor, o professor da disciplina e a pesquisadora, os quais, na realidade, tinham demandas internas muito diferentes. Portanto, os pesquisados tinham uma preocupação latente em suas Histórias de Vida: mostrar, no seu discurso ao professor da disciplina, a sua vocação para a profissão e, principalmente, para a pesquisa.

\subsubsection{Procedimento na coleta de dados da primeira fase}

A coleta de dados foi ampla, minuciosa e composta de anotações e de observações feitas em sala de aula pelo monitor, pela pesquisadora e pelos próprios alunos; filmagens de algumas atividades realizadas em sala de aula e elaboração, por parte dos pesquisados, da sua História de Vida. Em seus relatos, os professores contam fatos sobre a sua infância, sua escolarização e sua escolha profissional, sendo que, durante a narrativa, tentam estabelecer alguma relação entre esses momentos.

Os alunos tiveram um prazo inicial para realizar a entrega da primeira versão das suas histórias via e-mail, utilizando o arquivo Word anexado. Esta solicitação teve um objetivo e motivo específico: recebendo essa primeira versão, dessa forma, a pesquisadora pudesse, ao ler, colocar novas questões - suas dúvidas e perguntas sobre situações que não tinham ficado claras ou sobre aspectos que o pesquisado não tivesse abordado - em anotações feitas exatamente na posição do texto em que elas apareciam, à medida que a leitura progredia.

O que queríamos, realmente, era um envolvimento efetivo do pesquisado nesse diálogo porque, assim, as informações não precisariam ser repetidas a cada questionamento e proporcionariam uma visão mais integral da história que estava sendo contada. A relação que se pretendeu foi a mais dinâmica possível porque o pesquisado deveria fazer apenas alguns ajustes ou considerações no local exato do questionamento, fornecendo esclarecimentos rápidos e efetivos. O diálogo por essa via manteve uma boa dinâmica. O pesquisador procurou não demorar mais do que uma semana para responder cada e-mail. Para exemplificar melhor essa dinâmica, trazemos um pequeno extrato de uma das Histórias de Vida, em que aparecem assinalados, em fontes diferentes, as intervenções da pesquisadora e do aluno. Esse trecho, em particular, exemplifica uma etapa dessa comunicação em que a 
pesquisadora já havia feito uma primeira leitura, realizado uma intervenção e recebido a devolução do pesquisado:

Marta. Eu não gostava das provas, porque ficava nervosa de esquecer tudo na hora da prova, isso porque não sabia estudar, decorava tudo e durante a prova esquecia as palavras que eu não sabia o significado. A prova ficava com uns espaços em branco.

$\mathrm{Na}$ oitava série, decidi que queria fazer Física, porque gostava das aulas do professor de ciências. (Tente escrever mais sobre o professor de Ciências que te marcou tanto, desde a figura dele até como eram as aulas.) Ele era jovem, devia ter uns vinte e poucos anos. Acho que tinha terminado a faculdade a pouco tempo, na USP. Depois soube que ele fez pós-graduação e foi para a França e foi professor na USP. Não consigo me lembrar se ele escrevia na lousa, só lembro que falava bastante e dava algumas experiências. Lembro que ele era exigente e que tínhamos que estudar bastante para as provas.

Aproveitando ainda essa porta dialógica virtual aberta com as Histórias de Vida, foram feitas questões e avaliações sobre a dinâmica, materiais e interações da própria disciplina. Evidentemente, tínhamos uma quantidade muito grande de informações que, após leitura, foi selecionada para estabelecermos e escolhermos os dados a serem utilizados na pesquisa.

\subsubsection{Segunda fase da coleta de dados}

Ao procedermos uma análise preliminar das Histórias de Vida, com base na Análise do Discurso, utilizando os preceitos de Maingueneau (2005), não ficamos satisfeitos com o fato de que os elementos trazidos nos relatos não nos ofereciam subsídios suficientes para sustentar inferências sobre aquilo que mantinha uma possível escolha pelo magistério. Sentimos, então, necessidade de complementação das informações já obtidas, justamente para conseguir uma análise mais consistente sobre quais seriam os mecanismos objetivos e/ou subjetivos que podem manter o professor na situação de docência?

A segunda coleta de dados foi realizada durante o primeiro semestre de 2005 e constou de entrevista semi-estruturada com alguns dos professores que já haviam produzido suas Histórias de Vida. O roteiro de entrevista (ANEXO1) foi elaborado com perguntas que nos pareciam ter um potencial para criar progressivamente um clima de confiança e de descontração capaz de permitir ao pesquisado que se expusesse e até se surpreendesse com o próprio relato. Observamos que as questões da entrevista resgataram grande parte das informações sobre a História de Vida de cada entrevistado. 


\subsubsection{Critério de escolha final dos dados}

O desenvolvimento deste trabalho foi realizado com base nas Histórias de Vida de quatro professores e nas suas correspondentes entrevistas. Como já mencionado, essas entrevistas foram orientadas por uma análise preliminar baseada no conjunto de Histórias de Vida obtido ao longo da disciplina. Assim, a escolha dos professores a serem entrevistados teve como referência o envolvimento por eles demonstrado ao relatar aspectos pessoais e, ao mesmo tempo, a freqüência com que utilizaram a porta dialógica com a pesquisadora, que, no caso dos selecionados, foi de, no mínimo, quatro vezes.

$\mathrm{O}$ procedimento que adotamos de complementar as Histórias de Vida com as entrevistas mostrou-se bastante satisfatório não só porque trouxe novas informações, mas possibilitou à pesquisadora mergulhar mais profundamente nos elementos que marcaram a trajetória profissional dos professores e, ainda, criar uma familiaridade com o conjunto de informações capaz de sugerir novas inferências sobre aquilo que pode estar mantendo a escolha pela docência.

Cabe destacar que, do conjunto de informações obtidas com esse procedimento, selecionamos os dados guiados por um processo interpretativo que busca, essencialmente, atribuir significado aos elementos que poderiam estar sustentando a opção pela docência nos diferentes percursos de formação. Sabemos, no entanto, da nossa interferência subjetiva permeando a escolha daqueles que seriam os dados, principalmente porque a pesquisadora também é professora.

Souza e Vasconcelos (2003) corroboram essa nossa idéia quando nos esclarecem sobre como a seleção dos dados é feita, mostrando quanto os nossos esquemas de interpretação acabam organizando as situações e como essa organização já pressupõe uma atribuição de significado. Não podemos esquecer a importância do contexto de experiência quando selecionamos os dados de uma determinada situação a ser estudada. Não conseguimos reter todos os dados possíveis para a análise, mas "somente aqueles a que se atribui significado e que podem ser relacionados entre si mediante uma organização". Isso não quer dizer que os outros dados tenham sido esquecidos. Apesar do analisador não os utilizar imediatamente, eles se encontram disponíveis durante a interpretação, pois, implicitamente, estamos atribuindo significado ao dado quando o retiramos e o diferenciamos de todas as outras informações disponíveis. 
Esse processo de organização da escolha dos dados refletirá provavelmente nas relações que tentamos estabelecer entre os elementos que consideramos promissores no conjunto de dados, bem como na atribuição de significados, para responder a nossa questão de pesquisa. 


\section{REFERENCIAL TEÓRICO}

\subsection{ANÁLISE DO DISCURSO}

Durante a segunda metade do século XIX, com a contribuição da Psicanálise, entre outras ciências, as noções de sujeito e de linguagem sofreram modificações. O sujeito passa a ser considerado como sendo influenciado por elementos inconscientes interferindo no fluxo da consciência, o que o mostra como não transparente e incompleto, já que é, então, admitido como sujeito da linguagem. Pêcheux (1990), em fins dos anos 1960, é visto como o principal articulador da Análise do Discurso na França, criando uma nova maneira de se encarar a linguagem. O objeto de estudo não estava mais centrado apenas na fala, na escrita ou no texto em si, mas também se passou a dar importância para as condições, a situação no momento de produção de textos. Surge, então, uma nova questão, já que a atenção passou do texto para o sujeito: porque determinado tipo de sujeito faz determinado discurso? Considera-se que o discurso não existe independentemente do sujeito e a Análise do Discurso vem para tentar localizar o que está por trás dos enunciados, buscando estabelecer relações entre o dito e o não dito, tendo em conta as posições de sujeito que os indivíduos ocupam na sociedade.

Segundo Pêcheux (1990), quando um sujeito produz um discurso ele pressupõe um destinatário que se encontra num lugar determinado na estrutura de uma formação social. Esse lugar é representado, no discurso, por formações imaginárias que designam o lugar que o sujeito e o destinatário se atribuem mutuamente, ou seja, a imagem que cada um faz de seu próprio lugar e do lugar do outro. Esses lugares não estão apenas representados nos processos discursivos, mas transformados, o que indica que um discurso não é uma mera troca de informações entre A e B, mas sim um jogo de efeitos de sentido entre os envolvidos. Essas formações imaginárias são resultado da experiência humana ao longo do tempo, vivenciadas dentro do contexto social. Segundo Tavares (2004), essa imagem construída pelo indivíduo dessas posições que ele, o ouvinte, e o objeto do discurso ocupam e que é materializada através da linguagem, pode fornecer pistas sobre esse sujeito socialmente.

Dentro de uma situação histórica, encontramos enunciados que pertencem a formações discursivas e, quando o discurso é enunciado, o seu significado surge porque a memória discursiva coloca a possibilidade de serem feitas infinitas formulações dentro dessas 
formações que podem, como resultado, gerar o aparecimento, a rejeição ou a transformação de enunciados.

Um sujeito, quando produz um discurso, relaciona-o com tudo que já foi realmente dito de alguma forma, socialmente e historicamente, ou seja, com o interdiscurso ou memória discursiva.

A memória discursiva seria aquilo que, face a um texto que surge como acontecimento a ser lido, vem restabelecer os 'implícitos' (quer dizer, mais tecnicamente, os pré-construídos, elementos citados e relatados, discursostransversos, etc.) de que sua leitura necessita: a condição do legível em relação ao próprio legível. (PÊCHEUX, 1999, p. 52)

De acordo com Ferreira (2001), os seguintes autores também esclarecem o que é memória discursiva:

A memória discursiva faz parte de um processo histórico resultante de uma disputa de interpretações para os acontecimentos presentes ou já ocorridos (Mariani, 1996). Coutine e Haroche (1994) afirmam que a linguagem e os processos discursivos são responsáveis por fazer emergir o que em uma memória coletiva, é característico de um determinado processo histórico. Orlandi (1993) diz que o sujeito toma como suas as palavras de uma voz anônima que se produz no interdiscurso, apropriando-se da memória que se manifestará de diferentes formas em discursos distintos. (FERREIRA, 2001, p. 20).

A memória discursiva mostra a reutilização de enunciados. Elege, dentro de uma situação histórica específica, os elementos que podem ser atualizados ou rejeitados pelo discurso. A esse respeito Melo (1999, p. 100) comenta que: “A noção de memória discursiva exerce, portanto, uma função ambígua no discurso, na medida em que recupera o passado e, ao mesmo tempo, o elimina com os apagamentos que opera".

Segundo os analistas franceses do discurso, quando o sujeito muda de ambiente passa a assumir os discursos institucionais pertencentes a cada nova situação que ele vivencia como, por exemplo: o discurso da medicina, o discurso jurídico, o discurso científico, o discurso acadêmico, etc. A esse processo de adaptação discursiva dá-se o nome de assujeitamento. $\mathrm{O}$ sujeito se torna assujeitado porque ele se apropria de um discurso preexistente e faz uso dele e de suas regras também preexistentes. Portanto, podemos supor que não existem discursos originais ou textos individuais. A esses discursos não originais dá-se o nome de intertexto. Segundo Orlandi (1986) os textos efetivamente produzidos são intertextos, já que, para essa autora, a produção discursiva sempre estará atravessada por uma série de discursos preexistentes, ou seja, o sujeito deixa de ser sujeito e passa a ser assujeitado e o texto deixa de ser texto para ser intertexto. 
Bakhtin (1986) se contrapõe à análise francesa do discurso na medida em que coloca o sujeito não apenas como assujeitado, ou seja, o sujeito não é somente um divulgador de um discurso preexistente, mas dentro do processo discursivo, ele é capaz de gerar interferências que podem agir sobre o discurso social. Isto coloca o sujeito como ultrapassando os limites das dimensões institucionais.

Para entender os movimentos que ocorrem quando o sujeito fala de si, quando ele busca construir e reconstruir a sua história de vida, com o objetivo de nos revelar sua trajetória e opção pela formação docente, nos pareceu até natural ter como elemento promissor de análise a análise do discurso. Podemos pensar em como o sujeito fala através da memória discursiva, buscando as formações discursivas em que ele se localiza, e localiza o seu interlocutor, os apagamentos que ocorrem, que lhe validam o discurso como original. Não podemos esquecer também do assujeitamento que ele sofre, devido às instituições a que ele é vinculado, e tem que prestar contas.

No nosso caso, houve a necessidade de uma compreensão mais subjetiva dos eventos, levando em conta os aspectos que aparecem no discurso e que são capazes de nos dizer o que esse sujeito desejou nos contar. Observando a construção da narrativa na explicação da sua trajetória escolar e docente, percebemos as imagens que para ele foram importantes destacar com o objetivo de que fossem percebidas pelo destinatário do discurso. No aprofundamento do referencial da análise do discurso, encontramos o conceito de ethos modificado por Maingueneau (2005), que nos pareceu ainda mais promissor para interpretação dos eventos. 


\subsection{ETHOS E ANÁLISE DO DISCURSO}

Aristóteles ${ }^{9}$ (1998), na sua obra Retórica, integrou três elementos fundamentais do discurso: o ethos - quem fala, o lógos - argumento apresentado, e o páthos - a quem se dirige. O que ele nos mostra é que a persuasão, fornecida pelo discurso, pode ser de três espécies: a que reside no caráter moral do orador, ou seja, no ethos; a advinda do modo como se dispõe o ouvinte, ou seja, focalizadas no páthos; e, por fim, a centrada no próprio discurso devido àquilo que este demonstra ou parece demonstrar, ou seja, no lógos.

A retórica segundo, Plebe e Emanuele (1992), diz respeito ao que chamamos persuasão discursiva, ou, aquela que se origina e é exercida pela palavra e se apóia na força desse dizer. Podemos considerá-la como técnica ou arte de pensar, já que não existe retórica sem reflexão, sem argumentos, sem razões e, muito menos, sem a aprovação, ou não, do respectivo auditório. Isto porque os seres humanos são criaturas cujos pensamentos e decisões, via de regra, podem ser influenciados por apelos à emoção (páthos), como o são por elementos de persuasão, pois, dependendo da maneira com que o orador se coloca, pode conquistar a confiança do público, fazendo com que o seu discurso ganhe mais credibilidade (ethos) e, principalmente, através das possibilidades de escolhas de linguagem feitas pelo orador e pelas razões por ele invocadas (lógos).

A noção de ethos, nos estudos atuais, abandonou o sentido moral tradicional que foi cunhado por Aristóteles e passa a assumir novas possibilidades, ou seja, não se trata do que o orador diz sobre ele mesmo, mas do que revela pelo próprio modo que ele se expressa.

Para a Análise do Discurso, o texto do discurso pode ser oral ou escrito porque, em qualquer desses casos, existe a constituição da imagem discursiva do enunciador, ou seja, seu ethos. Maingueneau (2005) reinterpreta a noção de ethos acrescentando um caráter discursivo, pois, dependendo do posicionamento no qual o enunciador está inserido, irá assumir um determinado modo de enunciação.

O ethos "designa a imagem que o narrador constrói em seu discurso para exercer uma influência sobre seu alocutário”. (CHARAUDEAU; MAINGUENEAU, 2004, p. 220). Esse conceito diz respeito à imagem que um autor faz de si mesmo e diz respeito também como ele se imagina, ou quer ser percebido pelo leitor. O enunciador pode se revelar através de dois

\footnotetext{
${ }^{9}$ ARISTÓTELES. Retórica. Lisboa: Imprensa Nacional, Casa da Moeda, 1998.
} 
ethos: um, que ele, enunciador, se atribui, e um outro que é revelado a partir de como ele diz de si mesmo.

O discurso é produzido a partir de condições específicas, pois determina o surgimento de um discurso, e não de outros, já que se refere a “[...] determinadas circunstâncias, a saber, o contexto histórico-ideológico e as representações que o sujeito, a partir da posição que ocupa ao enunciar, faz de seu interlocutor, de si mesmo, do próprio discurso etc". (MUSSALIM; BENTES, 2001, p.116).

Nem sempre o ethos que se produziu é o ethos que se desejava mostrar, porque o ethos está ligado ao orador enquanto fonte de enunciação, mas é caracterizado pelo exterior, pois o ouvinte atribui ao orador, que está inscrito no mundo, traços extra discursivos que são realidades intradiscursivas, pois estão associadas a um modo de dizer, a uma escolha de palavras. Os traços extra discursivos levam em conta dados exteriores como o tom de voz, a mímica, o modo de vestir.

Em Maingueneau (2005) encontramos as idéias que nos auxiliaram na utilização do conceito de ethos. Segundo ele, ethos é uma noção que se constrói através do discurso, não é uma imagem exterior à palavra; e esse conceito tem relação com um processo interativo de influências mútuas entre orador e ouvinte, além de uma noção sócio discursiva, já que está relacionada a uma conjuntura sócio-histórica determinada.

Dentro da análise do discurso, Maingueneau (2005) configura ethos como parte da cena de enunciação, sendo esta cena pressuposta pelo discurso para que possa ser enunciada e validada por ele, ou seja, ela institui a situação em que o discurso se torna pertinente.

A cena de enunciação é integrada por três outras cenas que Maingueneau (2005) chama de cena englobante a que corresponde ao tipo de discurso: literário, religioso, filosófico, etc.; cena genérica a que está associada a um gênero, a uma instituição discursiva: o editorial, o sermão, o guia turístico, a visita médica, etc.; e a cenografia que não é imposta pelo gênero, mas construída pelo próprio texto: um sermão pode ser enunciado por meio de uma cenografia professoral, profética, etc.

Os gêneros do discurso podem ser divididos conforme Maingueneau (2005)

[...] em uma linha contínua com dois pólos extremos, de um lado, os gêneros que se atêm a sua cena genérica, que não admitem cenografias variadas (a lista telefônica, as receitas médicas, etc.). De outro lado, os gêneros, que por sua natureza exigem a escolha de uma cenografia: é o caso dos gêneros publicitários, filosóficos, literários, [...] Assim, há grande diversidade de cenografias narrativas em um romance. O discurso político é igualmente propício à diversidade das cenografias: pois um candidato poderá falar aos seus eleitores como jovem executivo, como tecnocrata, como operário, como 
homem experiente, etc., e conferir os lugares correspondentes a seu público" (MAINGUENEAU, 2005, p. 76)

A cenografia é um dispositivo que permite seja feita a articulação do discurso com sua origem e percurso, como, por exemplo, a História de Vida do orador e a sociedade em que ele está inserido. Maingueneau (2005) emprega o termo cenografia acrescentando à noção teatral da cena, a de grafia, ou seja, o modo como o discurso se inscreve e se legitima em seu modo de existir. Cenografia é utilizada ainda para designar o desenvolvimento da enunciação e instauração progressiva de seu próprio dispositivo de fala. Um ouvinte ou leitor reconstrói a cenografia de um discurso ou de um texto com a ajuda de diversos indícios que aparecem nestes.

Em relação à cenografia montada pelo narrador, podemos dizer que ela pode ser interpretada de maneiras diferentes, dependendo da experiência pessoal de cada leitor. Pois o leitor carrega as marcas da sua própria experiência de vida, suas lembranças e referências, o que faz com que os sentidos que ele atribui ao texto sejam diferentes para outro leitor.

Quando o leitor se convence dos argumentos do narrador, podemos dizer que ele é um fiador das idéias dele, portanto, para um enunciador, podem existir diferentes fiadores.

O discurso do narrador se torna o resultado de um complicado jogo de imagens, em que aparece a imagem que tem de si; a que ele gostaria de ter de si; a que ele tem do leitor; a que ele pensa que o leitor tem de si; a que ele gostaria que o leitor tivesse de si; etc..

Cenografia e ethos é um processo conjunto, pois quando o orador fala, a palavra já traz um certo ethos que vai se validando aos poucos. Esse ethos depende de diversos fatores, o pré-discursivo, o discursivo, o mostrado e o dito diretamente ou indiretamente, sendo que, muitas vezes, é impossível separar os limites entre o dito, o sugerido, o mostrado e o intuído, e as interações que ocorreram entre eles durante o processo de comunicação. Maingueneau (2005), chama incorporação à maneira como o ouvinte ou leitor, na posição de intérprete, se apropria do ethos, porque a enunciação dá uma corporalidade à argumentação, conferindo-lhe um corpus que é assimilado pelo destinatário. O poder de persuasão de um discurso será maior se estiver investido de valores que sejam historicamente reconhecidos pelo ouvinte ou leitor, pois é o ethos que garante, através da palavra, a identificação com esses valores e é através do enunciado, que essa força da persuasão é legitimada.

Ruth Amozzy (2005), articula a teoria da argumentação e análise do discurso ela introduz na análise do ethos o conceito de estereótipo. Estereótipo é conceituado como a construção de uma auto-imagem a partir de uma representação coletiva. Isto é, uma relação 
com imagens solidificadas, memórias pré-fabricadas de uma representação construída e congelada, mas que é partilhada culturalmente.

A eficácia do discurso é feita através de jogo especular em que o orador constrói sua imagem em função da imagem que ele cria de seu auditório. A esse espelhamento, Maingueneau (2005) chama de ethos pré-discursivo. Para ser reconhecido e valorizado pelo auditório, o orador se orienta por estereótipos para ter autoridade e parecer legitimo. Uma representação cultural pré-existente pode valorizá-lo em função do modelo pré-construído que circula na comunidade em que ele vive. O orador quer sempre criar uma imagem favorável de uma pessoa considerada responsável, que tem senso de dever, que é ligada a valores humanos, que inspira confiança, que deseja o bem do outro, que apresenta argumentos coerentes, que é simpática, generosa e altruísta. O discurso que está sendo emitido deve explorar essa imagem para atender às necessidades do seu auditório, já que a posição institucional do orador e a legitimidade que lhe é conferida são os fatores que contribuem para criar a imagem prédiscursiva.

Em resumo, avançamos em nosso estudo teórico até Maingueneau (2005), que nos forneceu o conceito de ethos de Aristóteles modificado, para ser utilizado na Análise do Discurso que optamos por adotar e que nos auxiliou na organização e interpretação dos dados. Das três cenas que integram a cena de enunciação, utilizaremos, no nosso trabalho a cenografia que não é imposta pelo gênero, mas construída pelo próprio texto, ou seja, o gênero da narrativa configura o gênero que, por sua própria natureza, exige a escolha de cenografia porque a História de Vida mostra inúmeras cenografias narrativas. Tentaremos, então, como fiadores que somos do texto escrito pelo narrador sobre sua História de Vida, reconstruir esta história tendo em mente as expectativas que tinha quando a escreveu. A nossa busca está nesse ethos consciente ou inconsciente construído pelo narrador ao falar de suas opções, principalmente em relação à escolha profissional.

E é exatamente esta reinterpretação de ethos, utilizada por Maingueneau (2005) na Análise do Discurso, que utilizaremos como referência para organização e primeira interpretação dos dados da nossa pesquisa. 
A. Diagrama explicativo da cenografia

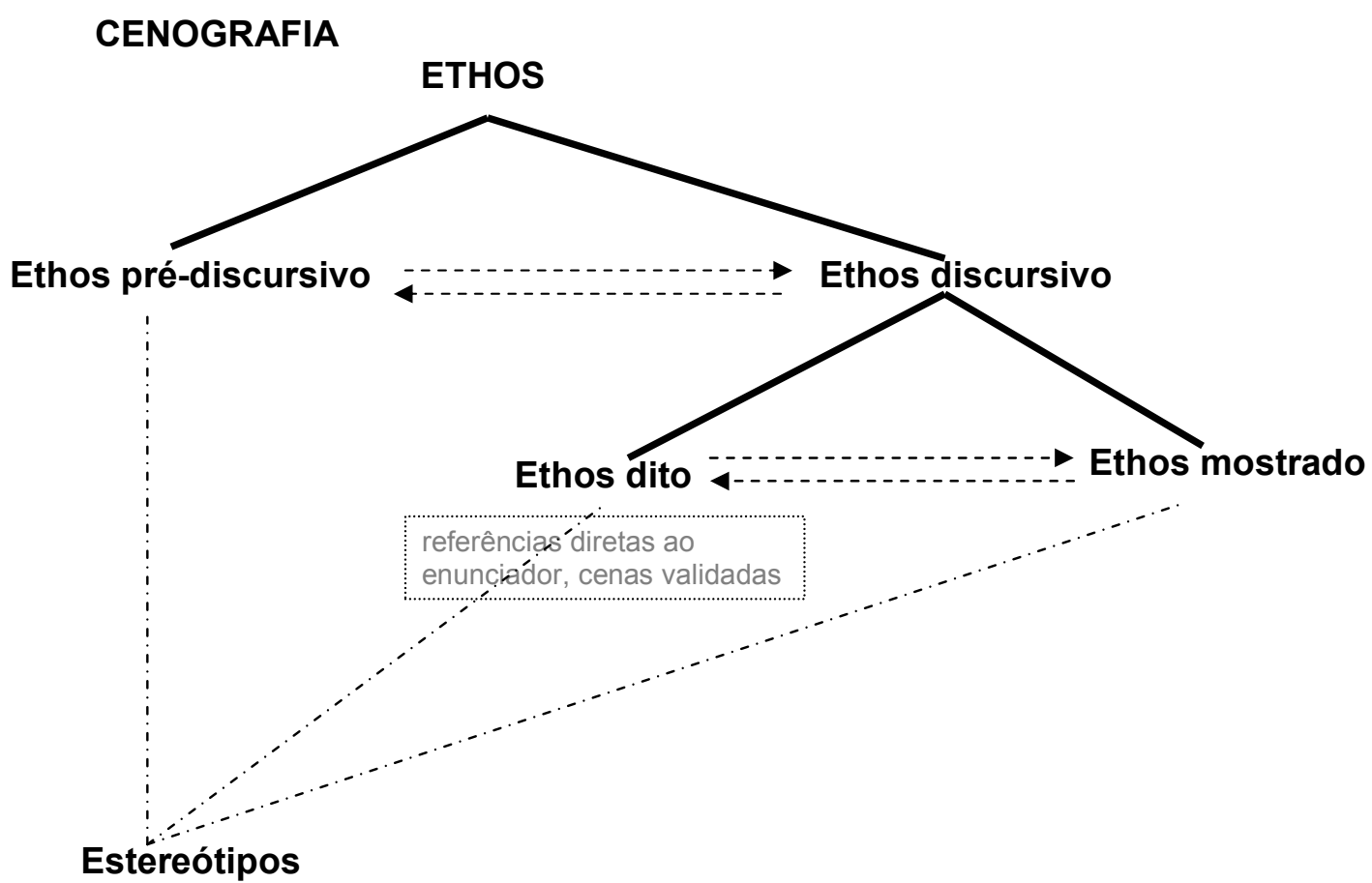

Diagrama extraído de Amossy (2005, pg 83) 


\section{AS HISTÓRIAS DE VIDA: ORGANIZAÇÃO E ANÁLISE}

Neste capítulo, utilizando as Histórias de Vida e o conceito de ethos proposto por Maingueneau (2005), realizamos uma articulação dos elementos encontrados, aos quais pudemos atribuir algum significado. Inicialmente, criamos cinco questões gerais para nos auxiliar a obter alguma organização dos dados. Depois, utilizando a análise do discurso, realizamos uma segunda organização usando uma estrutura com quatro aspectos que foram destacados da Análise do Discurso e que são: a. Aspectos gerais da vida do pesquisado Cenografia; b. Um pequeno perfil da sua atuação em sala de aula como aluno da pósgraduação - Ethos pré-discursivo; c. Análise da História de Vida; d. Utilização do referencial teórico. Ao final da análise de cada estrutura fizemos algumas considerações finais, verificando a pertinência do referencial utilizado na busca de pistas sobre a nossa questão de pesquisa.

\subsection{A ANÁliSE DO DISCURSO COMO REFERÊNCIA PARA ARTICULAR ELEMENTOS PRESENTES NAS HISTÓRIAS DE VIDA}

Quando contaram suas histórias, os professores se posicionaram de diferentes maneiras e esse seu dizer foi sendo construído dentro de diferentes discursos. No caso das Histórias de Vida, notamos que há os múltiplos eus da narrativa, como filho, professor em formação, aluno ou pesquisador. Dentro dessa perspectiva, das posições que o sujeito ocupa ao narrar a sua própria história, nos propusemos a utilizar a Análise do Discurso como elemento que nos ajudasse na análise dessas Histórias de Vida.

Olhando para estas histórias, e para as circunstâncias em que foram produzidas, percebemos que, na trajetória da narrativa, aparecem elementos que os sujeitos utilizam para montar um quadro de uma determinada situação, ou seja, criam imagens para, depois, discorrer sobre valores dos envolvidos na história e de si mesmo.

Para montar esse primeiro quadro, realizamos a leitura de todo o universo de pesquisados, ou seja, narrativas de 52 professores e vimos que apresentaram elementos capazes de responder às questões gerais que estabelecemos para primeira organização dos dados e, ainda, ao corpo de análise estabelecido por Maingueneau (2005). 
Após as leituras e na aparente desordem das informações, procuramos reorganizar os depoimentos buscando um conjunto de indícios capazes de propiciar alguma interpretação das informações oferecidas, com vistas à nossa questão de pesquisa. Com base nesses indícios selecionamos episódios que se configuraram como unidades de narrativa e que se relacionavam com a estrutura fornecida pela análise de Maingueneau (2005). Cada episódio, além de um tema em particular, fazia referências a pessoas e acontecimentos inseridos na narrativa pelo pesquisado com a intenção de nos fazer fiadores de seu relato. Buscamos, portanto, identificar, além da intenção do entrevistado em oferecer essas lembranças, os indícios de sua sustentação na docência. Entretanto, por razões já explicitadas na escolha dos dados, optamos por apenas quatro professores dentro desse universo.

Reconstruímos a história amarrando as relações trazidas à tona pelo narrador na tentativa de encontrar algum fio que ligasse todas essas atribuições e ações do professor, que, de alguma forma, fosse capaz de fornecer pistas gerais e, ao mesmo tempo, revelar aspectos singulares possíveis de manter um professor na docência. Nessa história pode aparecer o que é constituinte de todo o professor, mas também o que é particular do sujeito.

Nessa análise, optamos por organizar, em grandes blocos, as informações fornecidas pelos pesquisados elaborando questões norteadoras iniciais, pois possibilitaram recortes no texto que nos ajudaram na organização das idéias.

As questões gerais para primeira organização desses dados foram:

1. Quais os primeiros indícios da escolha profissional que ele fez?

2. Qual a imagem que ele está preocupado em construir?

3. Quem o ajudou nessa trajetória?

4. O que aparece no seu discurso sobre seus próprios professores?

5. O que ele conta sobre sua atividade profissional?

Essas questões gerais dividiram cada história em cinco blocos e, após essa organização, começamos a reescrever a história contada e a intuída, sugerida pela narrativa do pesquisado. Nas histórias, levamos em conta o que se quis contar, ou seja, quais informações acharam relevante narrar para responder à pergunta inicial, que solicitava informações sobre a trajetória pessoal, escolar e profissional. Consideramos para quem e em que circunstâncias essas Histórias de Vida foram contadas, já que, em nosso caso, tratava-se de uma disciplina de pós-graduação, para uma pesquisadora que já trabalhava num grupo de pesquisa do qual faziam parte o monitor e o professor da disciplina, aliado ao fato de que um conceito final seria atribuído à escrita dessa História de Vida. 
Chamamos, novamente, a atenção para o fato de que os nossos pesquisados tiveram os nomes, locais, nomes de instituição, etc, trocados para que suas identidades fossem preservadas:

Madalena, 44 anos, química, professora do ensino médio.

Maria, 48 anos, química, professora do ensino médio.

Deise, 40 anos, química, professora do ensino médio.

João, 28 anos, físico, professor do ensino médio.

Em busca de fornecer o maior número de informações e, ao mesmo tempo, familiarizar o leitor com as quatro Histórias de Vida selecionadas para este trabalho, em cada uma delas as informações foram distribuídas nos quatro aspectos e considerações finais.

a. Aspectos gerais da vida do pesquisado - cenografia. Esta seria a situação montada inicialmente pelo pesquisado, tão logo ele começasse a escrever ou falar, para introduzir os elementos e personagens que transitarão pela sua história, sendo que várias cenografias poderão aparecer durante a narrativa. Nessa situação haverá uma localização temporal e histórica do evento, ao mesmo tempo em que os personagens atuarão.

b. Um pequeno perfil da sua atuação em sala de aula como aluno da pós-graduação ethos pré-discursivo. Diz respeito às imagens que o narrador quis deixar inicialmente transparecer; ou desejava mostrar quando tomou determinadas atitudes; ou se comprometeu; ou se posicionou em relação a determinadas situações; ou algo que se diz sobre ele e que já foi reconhecido oficialmente. No nosso caso, diz respeito a algum conhecimento prévio que tínhamos dos pesquisados, ou às suas atitudes na sala de aula. Isso tudo, obviamente, sob o olhar da pesquisadora.

c. Análise da História de Vida. Essa análise diz respeito a aspectos que foram levantados a partir da interpretação empírica de trechos da narrativa, que trouxeram à tona alguns elementos oriundos das questões utilizadas para organizar os dados. Nessa interpretação, buscamos marcar situações que, mesmo respeitada a singularidade de cada História de Vida, de alguma forma, têm relação com outras narrativas. Esses elementos, que chamaram a nossa atenção, nos orientaram na busca de uma interpretação mais consistente. A História de Vida após essa análise empírica foi reinterpretada utilizando os conceitos de Maingueneau (2005).

d. Utilização do referencial teórico na análise da História de Vida. Pretendemos avançar na análise empírica que empreendemos utilizando os conceitos de cenografia, ethos pré-discursivo e discursivo, dito ou mostrado, e os estereótipos. Com relação ao ethos 
discursivo, dito ou mostrado, resolvemos por não separá-lo nessas duas sub-categorias. $\mathrm{O}$ próprio referencial teórico nos orientou sobre a dificuldade de se fazer essa separação, pois existe uma linha muito tênue, entre o dito, sugerido, mostrado, intuído e as interações no processo de comunicação.

e. Considerações finais. Aqui, pensando ainda nas múltiplas interpretações possíveis, marcamos alguns aspectos que se repetem no discurso e que, mesmo sendo particular do sujeito, também podem ser observados em outras histórias de outros sujeitos. A nossa tentativa nessa organização foi de encontrar pistas sobre a sustentação da docência.

\subsubsection{Madalena}

\section{a. Cenografia}

Madalena, 44 anos, química. Filha de pais imigrantes, que dão muito valor ao conhecimento. Estuda os primeiros quatro anos numa escola do interior em que os professores são autoritários, castigam e humilham. Depois, muda de cidade e escola e é muito boa aluna, apesar de dizer que o estrago já foi feito, porque ela se diz tímida e acredita que a escola não foi o lugar em que fez amigos, mas o lugar em que cumpriu as regras e os deveres com o objetivo de conseguir o diploma. No curso colegial trabalha de dia e estuda a noite. Entra na universidade pública, contando com apoio dos pais, os quais permitem que ela passe a só estudar até a conclusão do curso. $\mathrm{Na}$ universidade percebe as dificuldades do ensino deficiente que teve no colégio noturno. Corre atrás do prejuízo e vence as dificuldades, apesar de declarar que muitos conteúdos foram perdidos. Faz especialização e vai trabalhar na indústria. Casa-se, engravida e muda suas opções. Fica sem trabalhar um período. Resolve começar lecionar, inicialmente, na escola pública, depois, em cursos pré-vestibulares e, mais tarde, em faculdades. Nesse período, volta para a universidade para fazer Mestrado e atualmente espera uma chance para o Doutorado. Acredita que esse aprendizado na pósgraduação é necessário para a melhoria da sua prática na sala de aula.

\section{b. Ethos pré-discursivo}

Madalena em sala de aula, como aluna da pós-graduação, estava sempre provocando grandes polêmicas e discussões. A primeira polêmica foi sobre a escolha da análise qualitativa ou quantitativa em uma pesquisa. Como a maioria dos alunos, ela também achava mais coerente uma pesquisa quantitativa, o que acabou gerando muitas discussões sobre esse tema. 
Pretendia fazer um projeto de Doutorado que tinha como tema o ensino de Química envolvendo a questão ética e, nesse caso, propôs a utilização da química verde. Envolveu-se muito nos debates e a questão ética, para ela, era inegociável. Houve uma grande integração com a turma, a ponto de desempenhar vários papéis: defensora de um ponto de vista, mãe, colega da Química, aluna aplicada, porta-voz, etc.. Assim, sua contribuição, participando e questionando, foi valiosa na constituição do grupo formado na disciplina.

c. Análise da História de Vida.

Filha de emigrantes europeus tive uma formação familiar que valorizava profundamente o estudo. Independentemente dos meus pais serem apenas alfabetizados, sempre ressaltaram a importância da escola. Meus pais não interferiram na escolha da minha profissão e a função que incorporaram, foi de me apoiar nas minhas escolhas profissionais de uma forma bastante generosa. Tenho certeza absoluta que abdicaram de desejos pessoais para permitir que me graduasse em um curso que era integral e que, portanto, me impedia de trabalhar.

[...] Essa parte não me agrada muito relatar. Traçarei linhas gerais. Morava em uma cidade litorânea com escolas muito rudimentares e com professores muito mal preparados, o castigo fazia parte das aulas, regüadas, castigo no milho, puxões de orelha, humilhações... Esse período foi muito traumático e acredito que algumas das minhas dificuldades na escola, embora nunca tenha sido reprovada, deva-se a um medo imenso dos castigos. Essa fase assustadora durou quatro anos, depois meus pais me trouxeram para São Paulo, com escolas mais civilizadas, mas o estrago já estava feito. A escola não foi para mim um lugar de relacionamento e amizades, mas sim um lugar onde tinha uma obrigação a fazer, estudar, tirar o diploma e chegar à faculdade, meta que meus pais sempre valorizaram.

[...] Foi então que surgiu a proposta de trabalhar em um curso pré-vestibular, onde mulheres não são bem vindas, principalmente na área de exatas. Consegui me manter no cargo, o salário era ótimo, a pressão era enorme [...] descobri que meus alunos não eram meus inimigos, mas sim pessoas que precisavam do meu conhecimento para atingir seus objetivos e eu precisava do contato com eles para me sentir útil nessa vida [...]

[...] Optei por Química simplesmente porque a professora de Química do ensino médio era excepcional, não era uma profissional afetuosa para com seus alunos, mas tinha uma capacidade de nos encantar com a Química, de explicar de forma envolvente o conteúdo.

[...] como fiz meu ensino médio em escola pública no período noturno, trabalhava durante o dia. Quase não tive professores de Física. Esse era o profissional mais escasso, especialmente para o curso noturno, portanto me faltava base. Os professores (da universidade) partiam do princípio que todos estávamos no mesmo nível.[...] Não fui a pior aluna, mas, certamente, não fui a melhor. Tive que correr atrás de tanta deficiência oriunda do ensino médio que me classifico como uma sobrevivente que conseguiu se graduar em 4 anos.

[...] O que mais me encanta na minha profissão é a generosidade impregnada nela, pois se aprende para se poder transmitir, estuda-se para aprender coisas novas e devolvê-las aos alunos de uma forma que os encante. Dessa forma sinto-me útil, sinto-me participando da vida dos alunos e colaborando com a melhora dessa vida. Adoro o contato humano com meus alunos, acho que a sala de aula é o local da troca de experiências.

Madalena é filha de imigrantes europeus e, nas primeiras linhas de seu discurso, aparece a imagem de devedora, pois os pais, apesar de serem apenas alfabetizados 
valorizavam profundamente o estudo, e, segundo ela, devem ter abdicado de seus sonhos pessoais possibilitando que, naquele período, ela apenas estudasse.

Narra os traumáticos primeiros quatro anos escolares, os castigos que ela presenciava e as humilhações de que os alunos eram alvo. Mesmo depois de estar nas escolas ditas mais civilizadas, a escola, para ela, não é um lugar de amizades, mas, prioritariamente, um lugar de obrigações a cumprir para atender os desejos dos pais. Talvez, por esse motivo, tente criar sempre o melhor clima entre ela e o aluno. Quer garantir que exista realmente uma relação para só então se preocupar com a aprendizagem. Relata a difícil situação que viveu no ensino superior quando teve de vencer muitas dificuldades, principalmente em relação ao conteúdo, devido ao fato de que durante o colegial trabalhou de dia e estudou à noite. Essa situação criou uma defasem que ela teve que suprir para não decepcionar os pais. Por essa razão parece que ela se preocupa em traçar o melhor caminho para conduzir seguramente, sem sofrimento, o aluno através dos conteúdos.

Considera um desafio ser professora em cursinhos pré-vestibulares, principalmente na área de exatas, que é um reduto considerado potencialmente masculino. Declara-se uma vencedora, pois atua há 10 anos na área e adquiriu uma confiança muito grande no que ela chamou de "uma eficiência na transmissão do conteúdo". A sua escolha profissional parece ter relação com as qualidades que ela via na professora de Química, ou seja, a de conseguir encantar os alunos. $\mathrm{O}$ que nos parece é que ela está tentando repetir o mesmo tipo de encanto com os seus alunos. Se olharmos o fragmento do texto, perceberemos a referência ao encanto várias vezes. $\mathrm{O}$ encanto parece aqui ser a marca que ela deseja produzir no aluno em relação ao conhecimento científico, porque foi o encanto com que a professora transmitia o conhecimento que a marcou para a Química. Há uma referência reincidente, a necessidade do toque: 'eu precisava do contato com eles' e, em outro trecho 'Adoro o contato humano com meus alunos'. Esse contato, aqui, nos lembra algum tipo de cuidado, já que vem sempre depois de uma referência a alguma ajuda que ela pode fornecer em relação ao conhecimento que eles precisam, ou a melhoria da vida deles. Outra imagem que pode ser plausível é de que esse contato pode garantir, ao final, um reconhecimento amoroso, como se o contato físico fosse o termômetro e a garantia de que haveria aceitação e retribuição.

[...] Os alunos do ensino médio são jovens cheios de sonhos e esperanças [...] Os alunos da faculdade são [...] cheios de esperanças com relação ao mercado de trabalho. Faço sempre o que considero ser o melhor, converso com eles perguntando se o curso está caminhando da forma desejada, aceito sugestões, e parece-me que estamos construindo um curso interessante.[...] Acredito que a minha marca seja o bom humor. Não encaro o aluno como um ser perdido, acho que são apenas crianças grandes, cheias de energia que, algumas vezes, é difícil de controlar tal energia durante 50 minutos. Tenho meus 
momentos 'ordem no recinto', mas não consigo ser autoritária todo o tempo, apenas tempo suficiente para não perder o controle da sala.

Madalena faz de tudo para ser compreensiva com os alunos. Quer saber a opinião deles sobre o curso para atendê-los de forma eficiente. Para ela, eles são como 'crianças grandes, cheias de energia que algumas vezes é difícil de controlar'. Para obter o controle, ela utiliza a sua autoridade, apenas pelo tempo necessário. Preocupa-se em ajudá-los a realizarem seus sonhos, sejam eles alunos do colégio ou da faculdade. Acredita no seu bom humor como saída para as situações difíceis. Nos parece aqui que ela está tendo, para com seus alunos, o mesmo olhar de condescendência que uma mãe teria sobre as suas crianças 'cheias de energia'.

[...] Sinto-me responsável pelos problemas de aprendizagem, do não envolvimento com o conteúdo. [...] se a maioria tem dificuldade ou considera o conteúdo entediante, ou mesmo não gera participação, tento renovar minha aula, seja com novos exemplos, questionamentos ou experimentos. Estou, na maior parte do tempo, questionando sobre a melhor forma de apresentar determinado assunto.[...] ser professora significa colaborar com meus alunos a atingir seus objetivos: no curso pré-vestibular, entrar na faculdade, no ensino médio, fazê-los explicar o mundo utilizando linguagem e pensamento científico e na faculdade, colaborar na formação de um profissional ético e satisfeito. Sei que não consigo ajudar de maneira efetiva a todos meus alunos, mas fico feliz com os resultados positivos atingidos por alguns [...] Percebo também que não precisaria ser necessariamente professora de Química, o importante é ser professora, e a química foi uma questão de afinidade em função de uma boa profissional.

Madalena coloca-se como única responsável pelo não envolvimento do aluno. Culpase e se desloca em busca de soluções para a situação. Aciona inúmeras estratégias para controlar e obter bons resultados. Ela se responsabiliza pela conquista e pelo encanto desse aluno e o seu desejo é que todos obtenham resultados positivos. No seu discurso diz que mais importante do que ser professora de Química é ser professora. Percebemos que, se fôssemos estabelecer uma escala de prioridade, poderíamos dizer que, para ela, o mais importante é a relação que constrói do que manter o controle sobre o conteúdo. Uma necessidade é fazê-los explicarem o mundo utilizando a linguagem científica, ou seja, quer que, de certa forma, eles sejam sucessores do conhecimento científico.

d. Utilização do referencial teórico.

Cenografia: Na continuação da montagem da cenografia, ela fala do seu ingresso como professora do curso pré-vestibular, que é um reduto potencialmente masculino. Apesar do clima de rejeição e competição, ela tem a chance de mostrar e fazer valer a sua competência.

Ethos discursivo - Em diferentes momentos da história surgem várias imagens. Inicialmente, esse ethos é de quem se adapta às novas circunstâncias da vida e, por conta 
disso, faz de tudo para suavizar os caminhos dos seus alunos; depois, de quem acredita ter consciência de como a sua prática ocorre, ou seja, que tem algum poder e controle sobre ela; aparece a preocupação em criar um método eficiente de ensino, que seja capaz de conseguir ótimos resultados; finalmente, de quem se sente responsável pela aprendizagem do aluno e se culpa quando algo não dá certo, mas mesmo assim, está sempre buscando novas estratégias para encantar o aluno.

Observando as imagens criadas por Madalena quando conta sua história, parece haver uma necessidade de reedição às avessas dos problemas que ela viveu, ou seja, não quer que o aluno enfrente uma situação em que não tenha domínio sobre o conteúdo. O modelo que ela transparece é de professora competente e muito afetiva.

Não quer repetir, reeditar, as situações difíceis que aconteceram em sua vida; quer cuidar para que os alunos tenham um caminho sem sofrimento. Esse encanto que ela se preocupa em propagar faz com que se torne narcísicamente útil "sinto-me participando da vida dos alunos e colaborando com a melhora dessa vida" e garanta, desse modo, o recebimento de amor.

Resumindo, se pensarmos no aspecto da manutenção da docência, podemos inferir que talvez ela permaneça como docente por elementos de sua própria história; por tentar evitar os dissabores de que foi alvo durante a sua escolarização, como o medo de sofrer castigos; o clima desconfortável pela falta de amigos e as dificuldades com o terceiro grau devido à sua defasagem de conteúdos. Portanto, não quer reeditar as situações difíceis que vivenciou, pois não quer que aconteça o mesmo com seus alunos, quer poupá-los. O seu movimento é o de procurar, a qualquer custo, facilitar a aprendizagem deles, adaptando os conteúdos, para que eles possam ser felizes nas suas escolhas. Está em busca do reconhecimento da felicidade que lhes proporciona. A relação com o curso pré-vestibular é muito forte porque, além do reconhecimento explícito que recebe dos alunos, já por dez anos, os colegas da instituição, devido ao ibope ${ }^{10}$, são obrigados a aceitá-la.

\footnotetext{
${ }^{10}$ Ibope- nesse caso, faz referência a uma avaliação individual periódica do professor feita pelo aluno e que resulta em sua permanência ou não como professor no curso pré-vestibular.
} 


\subsubsection{Maria}

\section{a. Cenografia}

Maria tem 48 anos, nasceu em uma família em que o pai sempre teve muita preocupação com o conhecimento. Ele a introduziu na leitura e a ajudou nas lições de casa. A referência que faz ao seu pai é de seu mentor. Precisa trabalhar para ajudar financeiramente em casa, mas o primeiro emprego só acontece quase no final da graduação em Química. No início de sua carreira, quer trabalhar numa empresa, mas como não consegue emprego, o acaso lhe oportuniza aulas numa escola pública. Ela é conquistada para a profissão e desiste de procurar emprego na indústria. Dedica-se a ser a melhor professora possível e vai se especializando. Ministra aulas nas escolas públicas e em escolas particulares, mas, em determinado momento de sua vida, opta apenas pelas particulares. Já quase próximo à aposentadoria, talvez no atendimento a novas expectativas de vida, resolve investir num Mestrado e num Doutorado para continuar sendo professora.

b. Ethos pré-discursivo

Maria é uma professora de Química que, antes de tentar entrar no Mestrado, fez disciplinas como ouvinte ${ }^{11}$. A disciplina que está cursando, no momento, foi escolhida com objetivo de conseguir ajuda para escrever o seu projeto de pesquisa a ser desenvolvido no Mestrado. Ela é muito quieta como aluna, em sala de aula quase não participa das discussões sobre os textos e está sempre anotando qualquer consideração que seja feita pelo professor. Mostrou envolvimento e competência nas atividades que realizou como, por exemplo, apresentação do seminário e condução de discussão de textos. Mostra-se bastante insegura com o seu projeto de Mestrado. Possui duas propostas de projeto e não consegue definir qual a mais viável; uma é sobre o Estudo do Meio e a outra sobre como utilizar Dramatizações na estratégia de ensino.

c. Análise da História de Vida.

Bem, minha entrada no Mestrado aconteceu muito tempo depois de eu ter me formado na Faculdade [...]. Hoje, os alunos formam-se e, praticamente de imediato, já ingressam no Mestrado. Claro que analiso isso com aspectos positivos e negativos, pois quando se tem mais experiência eu acredito que se valoriza mais o que se faz, quando eu era mais nova, muito do que eu fiz, foi por sugestão dos meus pais, que sempre procuraram orientar os filhos no processo de crescimento e amadurecimento. Por outro lado, me dediquei [...] em adquirir experiência, fazer cursos de atualização como professora, [...]. Tenho um grande amigo [...], que costuma dizer que eu procurei tanto me especializar em como dar aulas, que esqueci de mim mesma, do crescimento de minha carreira.

\footnotetext{
${ }^{11}$ Ouvinte: nesse caso, aluno que não está regularmente matriculado na disciplina e que a cursa dependendo da autorização do professor que a ministra.
} 
[...] minhas expectativas com relação ao Mestrado? [...] é conseguir ser professora de uma boa faculdade, de preferência em um Curso de Química, que sempre foi minha paixão. Estou preparada para não parar no Mestrado, mas continuar até o Doutorado, pois só assim acho que conseguirei o que espero para minha carreira.

[...] Gostaria de me aposentar como professora de Ensino Médio e ingressar em uma boa faculdade. Quanto a escrever minha dissertação, percebi que o melhor, para mim, seria me basear em minha prática de professora e, a partir daí, escrever sobre a aplicação de estratégias de ensino e a aquisição aprendizagem significativa. Tenho um tempo para isso e vou fazer o possível para não estendê-lo [...]. Um medo que eu tenho é o de não conseguir cumprir os prazos, segundo minhas expectativas, pois trabalho em Escolas que costumam exigir dedicação e atenção, e tenho sempre que me dividir, o que não tem sido fácil, além das relações de família, que me exigem um tempo muito bom, porém nem sempre fácil de ser conseguido [...].

Maria prefere começar a sua história de vida pelo momento atual, ou seja, pela sua entrada no Mestrado. Fala sobre a influência dos pais nas suas escolhas pessoais e profissionais e na sua busca pessoal de uma melhoria de sua prática profissional. Para mudar seu paradigma de vida, se ampara na observação de um grande amigo que a ajuda a enxergar e justificar a sua necessidade de sair sem culpa das salas de ensino médio para as do ensino superior. Parece sentir-se culpada por estar buscando essa nova fase para a sua vida e justifica o fato de estar entrando só agora na pós-graduação, com o tempo que precisou investir com novos conhecimentos para conseguir uma melhoria na sua prática. Para fazer a pesquisa que pretende em ensino, ela acha imprescindíveis esses conhecimentos adquiridos durante anos em cursos de capacitação e na sala de aula. Por isso, talvez, se pergunte: que conhecimentos esses jovens têm para já estarem fazendo pós-graduação? Com o intuito de amenizar a sensação latente de culpa, pela mudança que pretende fazer, ela diz que vai para as salas de ensino superior só após a sua aposentadoria. Encerra o parágrafo falando sobre o medo de não dar conta dos prazos do Mestrado devido às exigências feitas pelas escolas particulares em que atua e pela sua família que "exigem um tempo muito bom, porém nem sempre fácil de ser conseguido". Aqui também nos parece estar se desculpando, e culpando, por talvez estar falhando com a escola e com a família.

Entrei na escola aos sete nos, já na primeira série, com um medo tremendo de não corresponder às expectativas de meus pais, como filha mais velha, o "exemplo" constante aos irmãos mais novos![...] Antes de entrar na escola, eu brincava que era professora, me lembro que eu tinha a idéia de que professor era muito bravo, talvez por meu pai ser muito severo nos limites que nos colocava, então, além de pedir giz à minha mãe, eu tinha também uma régua para bater na cabeça das crianças que me desobedecessem. Que coisa louca, não é?

[...] Desde pequena, livros e pequenas coleções acompanharam minha vida, conversas sobre o que eu havia lido, o que eu havia gostado mais (Coleções como Tesouro da Juventude, Monteiro Lobato, depois Shakespeare fazem parte dessas lembranças) principalmente de meu pai, que foi e tem sido um orientador em meu percurso.[...] Assim, quando retorno no tempo e relembro minha vida [...] a primeira coisa que me vem à mente é a forma como fui educada, no sentido de ter sido sempre muito estimulada à 
leitura, a ter tido sempre um acompanhamento muito próximo principalmente de meu pai. Não me lembro de estudar freqüentemente em grupo, meu pai costumava me ajudar nas minhas dúvidas, apenas no colegial comecei a estudar Física com alguns colegas, no $2^{\circ}$ ano, pois o professor era um padre que não ensinava absolutamente nada, ele errava os exercícios, não conseguíamos acompanhar seu raciocínio, e procuramos um professor particular, em grupo, e estudávamos juntos, para ver se conseguíamos entender, já que a esta altura, meu pai já não se lembrava de Física para me ensinar.

A família classe média de Maria lhe fazia muitas cobranças porque, como irmã mais velha, deveria ser tomada como exemplo pelos irmãos mais novos. Sempre foi estimulada à leitura e direcionada para o conhecimento pelo pai, que teve um papel de destaque na sua história, já que sempre lhe incentivou, ofereceu livros, estudou junto, ensinou tudo que ele podia. Quando entrou no ensino médio, ele não sabia mais Física para ajudá-la, então ela teve a oportunidade de estudar com os colegas e ter um professor particular. Acredita que um dos motivos da escolha da sua profissão foi porque gostava de brincar de professora, mas, mesmo quando relatou sobre isso, deixou bem marcada a influência do pai, pois disse que precisava de uma régua para bater na cabeça das crianças. Não usou a justificativa de ter visto ou ouvido alguém contar sobre essas barbaridades, mas, sim, que o pai era muito bravo.

[...] fui incentivada a praticar ciência, sempre tive aulas de laboratório, sendo que meus professores de Ciências Exatas tinham aulas mais interessantes do que os de Ciências Humanas, [...] Já os de Ciências, Química, Matemática, eram mais felizes, segundo me parecia, davam aulas com prazer, gostavam de nossas dúvidas, tentavam muitas vezes até nos orientar em nossas profissões. Me lembro que as aulas em que o professor falava sem parar, que eram de História e Geografia, me faziam ir longe [...] eu saía da sala de aula a voava em pensamento,[...] Já em química, tive professores extremamente exigentes, mas [...] eu conseguia ver uma razão para tanta exigência. Um dos meus professores, Prof. Tulio, nos fazia mostrar as mãos depois das aulas de laboratório, se estivessem manchadas, éramos descontados, tínhamos que trabalhar com método e cuidado [...]. Meu professor, como já relatei, era enérgico, bravo mesmo, mas explicava muito bem, eu acho que ele adorava a química, pois passava para nós todos um amor ao que ele ensinava que muitos de nós seguimos carreiras ligadas às ciências, com ênfase em química.[...] Quando comecei a trabalhar, levei muito do que acreditava para a sala de aula, sempre procurei não falar a aula toda, [...] fazer aulas práticas que se relacionassem com a teoria [...]. Quanto ao aspecto do que me foi ensinado, como foi ensinado e como ensino hoje, considero que procuro manter o mesmo interesse pelas idéias dos alunos [...] que os professores que mais admirei mostraram a mim.

[...] acabei sendo indicada em 1984 para fazer parte de um grupo de professores que começou a esboçar as mudanças no Currículo de Química do Ensino Médio. Foi muito bom ter ficado cerca de dois anos nesse grupo, até que a escola particular apareceu com mais força em minha vida e eu acabei não conseguindo tempo para tudo. Larguei o grupo e continuei a trabalhar mais intensamente em sala de aula.

Maria foi muito influenciada pelos seus professores. Podemos observar no seu discurso a referência a aspectos positivos e negativos que ela atribuiu a eles e que hoje ela menciona nas suas considerações, quando faz referência às estratégias que utiliza em sala de aula. Por exemplo, temos a situação em que nos conta que o seu professor falava sem parar e 
que esse fato, além de ser muito cansativo, fazia com que ela viajasse em seus pensamentos para longe da sala de aula. E, hoje, sobre sua prática em sala de aula, nos diz que procura não falar a aula toda. Conta que utiliza muitas aulas práticas, tenta manter sempre uma dinâmica em que o aluno também possa falar e, mais do que isso, se empenha em não repetir o que entendia como os erros que seus professores fizeram. Mostra, na sua narrativa, a importância do professor de Química na sua escolha profissional e justifica, as atitudes enérgicas que ele tinha, dizendo que elas não eram gratuitas. O mais marcante desse professor é que conseguia demonstrar o amor que tinha pela Química e, assim, acabou influenciando a escolha profissional de grande parte de seus alunos.

Maria acredita que se constituiu professora, através das relações vividas em sala de aula como aluna e que essa boa lição e boa atuação a tornaram uma boa professora, pois, foi convidada para integrar um grupo de pesquisa preocupado em repensar o ensino de Química, o que a envolveu por um tempo. Quando resolve deixar o grupo de pesquisa, justifica-se com o fato de ter mais aulas para dar nas escolas particulares e, por esse motivo, teve que abandonar, talvez com culpa, essa sua primeira incursão na pesquisa. Ela se coloca como paciente da situação; a escola particular foi quem apareceu na sua vida com mais força para mudar os planos e não detalha o que está realmente por trás da sua escolha que, provavelmente, seria a melhoria do salário.

À medida que o tempo foi passando, senti que já era momento de investir em minha carreira, no sentido de ir para uma faculdade, indo fazer o Lato Sensu em Química [...] Na verdade, a idéia mais concreta para fazer o Mestrado aconteceu em conversa com minha professora de Físico-química, Prof ${ }^{\mathrm{a}}$. Dra. Liza, que contou sua história, como fez o Mestrado na Poli, com quarenta aulas semanais, e mais tarde o Doutorado, já mais tranqüila, com mais tempo [...].

$\mathrm{Na}$ ordem de influência que aparece em sua narrativa encontramos o pai, o professor de Química e, agora, a professora Liza, que a incentivou a fazer o Mestrado. O movimento que faz nos sugere uma justificativa, já que parece ter medo de que a pós-graduação a obrigue a diminuir o ritmo de trabalho, talvez, um pouco excessivo que vem desenvolvendo. Preocupa-se em sempre deixar claro, no seu discurso, que existem pessoas que não precisam abdicar do número de aulas, nem da diminuição do salário, para conseguir fazer um Mestrado. Justifica que, mais tarde, assim como a professora, vai ter mais tempo para se dedicar a um Doutorado, pois vai estar aposentada. Ou seja, avisa que não vai desistir do número de aulas agora, mas promete que, no Doutorado, vai reservar esse tempo, que vê como necessário para a realização de um bom trabalho.

Acredito que a postura de respeito, seriedade, transparência que sempre tentei mostrar a meus alunos, que minha paixão pela Química como ciência [...] vai ficar na memória dos 
meus alunos [...] sei que a química e muitos conceitos vão se perder se meus alunos não continuarem a estudar essa ciência, mas o que fica do relacionamento e do vínculo que criamos permanece e espero ser importante para a vida deles. Sei que erro muito, até por tentar alguns novos caminhos, por buscar uma qualidade e motivação maior dos estudantes, mas tenho tentado me fundamentar cada vez mais para depois testar novas experiências. E é nessa busca que pretendo desenvolver minha dissertação de Mestrado, que sei que não trará grandes respostas, mas abrirá novos estudos para um futuro Doutorado.

Maria traz à tona seus professores, que são os ideais que acredita e utiliza, quando mostra o modelo que quer ser para os seus alunos. Acredita que, mostrando a sua paixão pela Química, como seu professor mostrou, pode ajudá-los a ter uma boa relação com esse conhecimento e que essa sua atitude talvez possa influenciá-los a desejar saber mais.

Quer marcar os alunos no sentido de fazê-los sucessores do conhecimento que carrega, mas, mesmo que não consiga, quer deixar uma outra marca: a de fazer com que o vínculo que criaram seja importante na vida deles. Não quer ser esquecida por suas atitudes em relação ao conhecimento -“que isso vai ficar na memória dos meus alunos"- e nem tampouco pela relação amorosa que ela consegue manter em sala de aula. Essa relação amorosa vai além do conhecimento sobre a Química, já que o que ela pretende é a permanência dos vínculos que foram criados. Ainda nesse trecho, recomeça, uma justificativa sobre os motivos que a levaram ao Mestrado. Dessa vez, considera que foi para aprender mais, se fundamentar e corrigir seus erros, ou seja, ela oscila entre o desejo de fazer a pós-graduação e a culpa em deixar o ensino médio na busca desse novo status de professor universitário.

Com relação ao conhecimento científico, embora não apareça explicitamente nas declarações de Maria, podemos inferir essa importância quando fala da suas expectativas em conseguir fazer o Mestrado e Doutorado para continuar sendo professora. A relação com o conhecimento parece não ter limites, já que, aparentemente, todos os embaraços que está vivendo nesse final de carreira no ensino médio, não a desanimam a enfrentar os desafios que estão por vir. "Estou preparada para não parar no Mestrado, mas continuar até o Doutorado, pois só assim acho que conseguirei o que espero para minha carreira".

No seu discurso aparece o amor do seu professor pela Química, que foi capaz de influenciar os alunos a seguirem carreiras ligadas à Química, o que faz com que ela também se envaideça quando consegue o mesmo efeito sobre os seus alunos. "[...] que ele adorava a Química [...] um amor ao que ele ensinava que muitos de nós seguimos carreiras ligadas às ciências, com ênfase em química”; “[...] que minha paixão pela Química como ciência [...] vai ficar na memória dos meus alunos". 


\section{d. Utilização do referencial teórico.}

Cenografia: A nova cenografia montada por Maria é de uma professora em final de carreira que busca a pós-graduação para iniciar uma nova fase profissional, mesmo sabendo que vai concorrer com um grupo de pessoas mais jovens da área de ensino para conseguir vagas. No discurso de narrador, quando ela fala de seus próprios professores, percebemos que o julgamento que fez sobre eles, como bons ou maus, serviu de modelo para fortalecer as suas crenças e atitudes como professora. O momento particular que ela vive, de uma professora que está próxima da aposentadoria, lhe possibilita construir uma imagem crítica, sobre a sua situação atual que é de quem tem muito conhecimento sobre a prática, mas que é desvalorizado, na medida em que a escola the solicita apenas energia para dar conta das inúmeras atividades extra classe. Empenhou-se na construção de uma imagem de professora que já cumpriu um papel, que estudou muito e que abdicou de seu desenvolvimento pessoal em prol dessa prática. Agora, é a vez de cuidar de si.

Ethos discursivo: Maria mostra a dívida que tem para com a sua família e a influência que teve nas suas escolhas. Esta dívida fica muito bem marcada pela presença do pai, que ela coloca na posição de seu orientador e que lhe proporcionou livros e conversas sobre as leituras que fazia desde a infância. O pai é a pessoa a quem ela presta contas e é a primeira influência na construção da imagem ideal de professor que ela utiliza. $\mathrm{Na}$ escola teve professores especiais, como os professores das áreas de exatas e de ciências, mas, o mais marcante deles foi o de Química que, segundo ela, influenciou grande parte da sala de aula a atuar nessa área. Acredita que a própria experiência profissional pode ajudá-la na sua pesquisa. Justifica que não está abandonando os alunos quando procura ingressar no Mestrado. Tenta se explicar, através da observação de um amigo, de que ela esqueceu de evoluir enquanto se especializava no exercício da profissão. Esteve envolvida com um grupo de reelaboração do Ensino de Química no Ensino Médio, mas acaba abandonado-o e se justifica com o aparecimento de mais aulas nas escolas particulares. Preocupa-se em mostrar que faz uso, em sala de aula, dos bons exemplos de seus professores. Não quer se esquecida, quer ser reconhecida como uma pessoa competente, que busca ser uma professora ideal nas suas práticas e na relação com os alunos. Quer tê-los como sucessores do conhecimento científico de que é detentora e influenciá-los em suas vidas. Esse conhecimento lhe foi apresentado pelo seu professor que era muito enérgico, mas que mostrava o seu próprio amor ao conhecimento científico e que foi capaz de contagiá-la.

A imagem inicial construída por Maria é de culpa, já que se mostra uma pessoa que precisa da voz do amigo para justificar a necessidade de crescimento pessoal, pois seu melhor 
investimento, até então, era melhorar a sua prática em sala de aula. Pela sua lógica o crescimento pessoal e profissional na nova fase que ela vislumbra para sua vida, só vem com a pós-graduação, a aposentadoria e o abandono das aulas do ensino médio em favor das do ensino superior. Há um ethos de reconhecimento da ajuda que o pai lhe deu e justificação do rompimento da relação de dependência -“já que a esta altura, meu pai já não se lembrava de Física para me ensinar". As imagens de pai e professor são tratadas como uma só. Mostra o ethos de pessoa que quer obter reconhecimento narcísico de suas atitudes, como professora e como pessoa, porque diz: "que isso vai ficar na memória dos meus alunos [...] mas o que fíca do relacionamento e do vínculo que criamos permanece e espero ser importante para a vida deles". Cria o estereótipo de professor ideal construído a partir das situações positivas da sua experiência escolar e da boa influência de seus professores.

Resumindo, podemos inferir, após a observação das imagens criadas por Maria sobre a sua vida e opção profissional, e baseados nos elementos que destacamos do seu discurso, que a manutenção da docência pode estar se dando ou se sustentando em várias situações descritas, como, por exemplo, as possibilidades que lhe são dadas pela família em relação ao conhecimento e as influências que a marcaram na escolha profissional. Pode estar presa à necessidade de manutenção de uma imagem de professor ideal e de reedição das experiências como as que viveu, com os modelos que a influenciaram. Mostra uma necessidade de fazer marcas, que se traduz de duas maneiras: ter o aluno como sucessor do conhecimento científico e de influenciá-lo em sua vida em outras decisões que ele venha a tomar, ou seja, quer ser capaz de provocar mudanças e fazer diferença na vida e na escolha dos alunos. Está marcada pelo conhecimento científico, que foi o que lhe possibilitou transferir o amor pela Química aos seus alunos. Há uma expectativa pelo reconhecimento do seu trabalho com algum tipo de retribuição, sobretudo por parte de alunos, pais e escola. Além de uma necessidade de fazer muitas justificações, seguindo sempre a mesma lógica, de, aparentemente, encobrir a culpa, talvez, por estar colocando na frente dos possíveis desejos do aluno, os seus próprios desejos. 


\subsubsection{Deise}

\section{a. Cenografia}

Deise, 40 anos, nasceu no interior do estado de São Paulo e veio para a capital com 2 anos de idade. A mãe, filha de portugueses, morre quando ela tinha treze anos, seu irmão quinze anos e sua irmã mais nova seis anos de idade. Então, ela passa a cuidar da casa. A mãe fez apenas o ensino fundamental; era severa e muito religiosa; ia todo o domingo à missa e participava de procissões e quermesses. O pai viveu na roça e estudou, inicialmente, até a $3^{\mathrm{a}}$ série do ensino fundamental, depois, continuou estudando e fez supletivo do ginasial e do colegial. Deise estudou em escolas públicas na zona leste da cidade de São Paulo. O ensino fundamental foi feito em escola estadual. Da $5^{\mathrm{a}}$ a $8^{\mathrm{a}}$ séries esteve numa escola da prefeitura e o ensino médio em um colégio estadual, que necessitava de vestibulinho ${ }^{12}$ para ingressar. Os cursos de bacharel e licenciatura em Química e Mestrado em Ensino de Ciências ocorreram numa universidade pública.

\section{b. Ethos pré-discursivo}

Deise é professora de Química num colégio particular, que foi criado por uma espécie de cooperativa de professores, os quais desejavam uma escola inclusiva, com alunos que fossem autores da sua própria relação com o conhecimento. Deise é Mestre em Ensino de Química e a maioria dos professores dessa escola também são mestres em suas áreas de conhecimento.

c. Análise da História de Vida.

Nasci no interior de São Paulo e vim para São Paulo com 2 anos de idade. Minha família era composta por pai, mãe, um irmão dois anos mais velho e uma irmã (6 anos mais nova que eu). Estudei em escolas públicas na zona leste de São Paulo. O ensino fundamental I foi em escola estadual o de $5^{\text {a a }} 8^{\text {a }}$ foi numa escola da prefeitura, o ensino médio em um colégio que necessitava de vestibulinho para entrar e o curso de bacharel, licenciatura e Mestrado em ensino de ciências ocorreu na USP de são Paulo.

Pai: filho de trabalhadores da roça estudou até a $3^{\mathrm{a}}$ série do ensino fundamental em Minas Gerais e, já casado e com filhos em São Paulo, estudou na indústria em que trabalhava para terminar o ensino fundamental, fez supletivo ginasial e colegial e cursos de segurança. Ele adorava, e adora até hoje, contar estórias de quando era leiteiro, dos bailes na roça e das oportunidades que não pode aproveitar quando pequeno, pois trabalhou desde cedo.

Lembranças da minha infância: Cantava músicas saudosas do interior e contava estórias e histórias e adorava testar os filhos com adivinhações (O que é o que é...) e mostrar que fazia cálculos mentais mais rapidamente que os filhos, mesmo sem saber essa nova aritmética. Também gostava de ler (bíblia, jornal e o que aparecia em sua mão) e dizia que só com estudo podemos "crescer na vida".

\footnotetext{
${ }^{12}$ Vestibulinho - pequeno vestibular solicitado por escolas que apresentam muita concorrência entre os alunos, com o objetivo de fornecer uma vaga.
} 
Mãe: filha de portugueses que tinham um pequeno sítio. Completou o ensino fundamental na infância (terminou o "grupo escolar"), era costureira tinha uma letra desenhada e era muito religiosa. Era mãe rígida, mas doce, preocupada com a educação e formação dos filhos, caprichava em tudo o que fazia, ia quase todos os domingos à missa, participava de procissões e quermesses. Morreu jovem (39 anos) com câncer e sofreu por pelo menos 4 anos com essa doença, sem demonstrar desesperos, apenas preocupação com os filhos.

Lembranças da minha infância: Ela ajudava os necessitados e me incumbia de alfabetizar algumas crianças carentes que eram pedintes na porta de casa e que não freqüentavam a escola. (Eu desisti depois de perceber que não conseguia "ensiná-los a ler e escrever")

Irmãos: Nenhum problema entre nós que não fosse normal entre irmãos. Com o falecimento da minha mãe, eu (13 anos) meu irmão (15 anos) e minha irmã (6 anos) ficamos morando em casa com meu pai e os laços familiares ficaram mais intensos. A união permanece até hoje. Todos os irmãos são dedicados no que fazem e perseverantes.

Na história de Deise verificamos que o pai parece ter uma influência grande sobre o futuro dos filhos, pois, mesmo humilde, se coloca como modelo quando consegue vencer nos estudos ainda que atrasado e com dificuldades. Esse movimento de continuar estudando em uma situação que foi proporcionada pela indústria em que trabalhava e, depois, sozinho, fazendo o supletivo e cursos para trabalhar como segurança, não pode ter passado desapercebido pelos filhos. Consegue transmitir a eles um gosto pelo conhecimento através de suas histórias, nas adivinhações e nos cálculos mentais, que era a situação em que ele mostrava ser detentor de algum tipo de saber maior que o deles.

Devido à família ser muito religiosa, o pai lia a Bíblia e, principalmente, pela mãe que participava de procissões, aparece uma situação que já foi muito comum nas cidades do interior, que era o fato de as pessoas ajudarem sistematicamente os menos necessitados. Por isso, Deise nos fala da sua ajuda aos menos necessitados e a alfabetização que tenta fazer, influenciada pela mãe, dessas crianças carentes que eram pedintes.

[...] Me lembro do meu pai dizendo que iria comprar uma máquina de costura para que eu fosse uma costureira como minha mãe. Isso me deixava muito irritada, pois não queria ficar sentada em frente a uma máquina de costura como eu sempre a via. Dizia então que ia ser professora. Desde pequena gostava de ensinar os colegas que não entendiam a matéria.

Inicialmente a influência a ser professora foi da minha mãe, me pedindo para que ensinasse aos que não sabiam ler e escrever, a valorização ao estudo sempre enfatizada por meus pais e depois as professoras primárias que tinham uma dedicação intensa e me incentivavam.

Depois, três professores tiveram grande influência. Uma professora da $1^{\mathrm{a}}$ série que nos contou que o homem tinha chegado à Lua, da importância do conhecimento e que nós ainda iríamos visitar esse satélite da Terra em ônibus espaciais - Ao chegar em casa contei aos meus pais o grande feito e ouvi do meu pai que isso era mentira, que nenhum homem poderia sair da Terra e isso era invenção dos estrangeiros - (foi um momento de frustração que me fez pensar pela primeira vez em contribuir para diminuir a ignorância das pessoas). Uma professora primária que me premiou com um livro (Reinações de Narizinho de Monteiro Lobato) pela minha dedicação aos estudos - foi meu primeiro livro não didático, pois até então eu só lia "Caminho Suave" e pedaços de jornal que vinham embrulhando a carne ou as bananas. Um professor de Matemática (na 6. série) 
que, devido a minha facilidade com essa disciplina, me colocava como sua assistente para ajudar os colegas que não compreendiam a matéria.

Não tenho dívidas para com essas pessoas, pois acredito que, de uma forma ou de outra, eles conseguiram me encaminhar no que acreditavam ser importante.

Aparentemente o pai de Deise brincava dizendo que ela deveria ser costureira como a mãe. Nessas ocasiões ela se chateava, porque levava isso a sério e dizia que seria professora, pois já tinha vivenciado uma experiência desse tipo com a mãe e as crianças carentes. Falando de seus professores, nos conta uma situação marcante no primário ${ }^{13}$ : o fato de o homem ter chegado à lua e seu pai simplesmente não ter acreditado. Quando fala sobre a frustração desse momento, imaginamos que diga isso olhando com os olhos de agora, porque, aos sete anos, nos parece, não poderia ter tanta certeza sobre a ignorância do pai e, muito menos pensar em ser algum dia alguém capaz de diminuir a ignorância das pessoas. Outra professora deu-lhe um livro de leitura como prêmio, que não era a cartilha, o que foi muito importante já que não tinha acesso, por dificuldades financeiras, a esse tipo de leitura. Na sexta série ela passa a auxiliar o professor devido à sua facilidade com a Matemática.

Apesar de declarar que não tem dívidas para com esses professores, no sentido de que não desprezou as oportunidades que eles lhe proporcionaram, no nosso sentido de dívida, entretanto, nos parece que ela tem dívida sim, com o seu pai, que lhe mostrou o conhecimento inicialmente de uma forma muito agradável com adivinhações e desafios matemáticos. A relação com o conhecimento científico foi estabelecida, nos parece, com a professora primária que trouxe uma notícia importante que foi muito marcante naquela época. As considerações que faz sobre como foi chocante perceber a ignorância do pai em relação à ciência, parece corroborar a sua própria fé na certeza e infalibilidade da ciência. Foi muito importante o reconhecimento que ela recebeu dos seus professores que começa com o livrinho infantil e depois, na assessoria dada ao professor de Matemática. Nos diz que todas essas atenções surgiram devido às facilidades que ela tinha em relação ao conteúdo ensinado.

[...] é a profissão que eu escolhi, que eu trabalho já há muitos anos porque eu quero Não foi por falta de opção de outra coisa, eu acho que estou na área da educação, sou uma educadora porque eu me preocupo com o que os alunos aprendem, como eles aprendem, como fazer pra eles melhorarem a aprendizagem e, também, a relação com o mundo que o cerca. [...] muita paciência, pesquisa o tempo todo, ta sempre procurando coisas novas, pra poder trabalhar em sala de aula, pra poder conhecer ler um pouco sobre as teorias de aprendizagem, conhecer um pouco sobre isso , pra não ficar o que aprendeu há 20 anos atrás pra não achar que aquilo é sempre correto .é...saber lidar com o adolescente é saber lidar com o outro. [...] agora o problema da indisciplina é um problema meu que me atrapalha e com as novas gerações parece que está sendo pior, e quando eu não consigo

\footnotetext{
${ }^{13}$ Primário: nessa época era denominado primário, os quatro anos iniciais da alfabetização e tinha uma certificação final.
} 
fazer com que a classe fique.... envolvida com o conhecimento, com aquilo que eu to querendo trabalhar com eles [...]eu fico muito frustrada, eu não consegui resolver isso ainda o que fazer quando os alunos não estão nem aí.[...] Preocupada... com o conhecimento menos pesquisadora do que antes, não na parte pedagógica, mas da parte do conteúdo ...da ciência, ando lendo menos. Eu acho que eu devia ler mais porque eu ai terei argumentos melhores para discutir com os alunos.

Deise se frustra quando não tem controle da disciplina dos alunos, acredita que, para ser uma professora eficiente precisa adquirir cada vez mais conhecimentos, seja sobre as teorias de ensino, sobre atividades para a sala de aula ou, até mesmo, sobre a relação com o seu aluno adolescente. Isto quer dizer que se coloca como responsável pelo insucesso, se ele ocorrer. Existe uma necessidade de ter maior controle da situação na sala de aula porque, só assim, sente que pode dar vazão aos seus desígnios, ou seja, ajudar o aluno na aprendizagem.

Os alunos de um modo geral me tratam bem. Quando fazem perguntas de algo que não entenderam ou relacionado à disciplina de química e eu consigo responder ou mudar a estratégia para facilitar a compreensão, percebo que há reconhecimento do que faço através de expressões como: _ Agora eu entendi!; _ Olha, a professora sabe!_ Por que você decidiu escolher química? Tem muita coisa pra saber.

$\mathrm{O}$ reconhecimento maior ocorre quando percebo que os alunos aplicam alguns conceitos aprendidos em situações cotidianas e eles me contam que conseguiram explicar (está ficando cada vez mais raro).Gostaria de influenciar os alunos a serem curiosos, a valorizarem o conhecimento, seja ele qual for e a "ganharem tempo" estudando, sem esse pragmatismo (pra que serve isso?).

Deise nos fala do reconhecimento que os alunos fazem do seu esforço em buscar explicações que os ajudem a entender melhor os conteúdos. Sente-se reconhecida quando os alunos conseguem explicar, para outras pessoas, situações do cotidiano cujos conceitos aprenderam com ela em sala de aula. Esse reconhecimento lhe faz muito bem, e nos parece ter a ver com uma retribuição, quase amorosa, dos seus cuidados na administração dos conteúdos e em poder vê-los andando sobre as próprias pernas. O conhecimento científico deve ser valorizado, segundo ela, e gostaria que o aluno não usasse o álibi de não estudar os conteúdos simplesmente porque questiona a utilidade deles.

Coisas que mais me chateiam: falta de respeito com colegas e com o professor, apatia, falta de empenho e frases do tipo: Em que isso vai ser importante na minha vida?

O que mais gosto na sala de aula: interesse, perguntas sobre o conteúdo que está sendo abordado e que vão além dele, tentativa de uns em ensinarem aos outros, quando o conceito não foi entendido e sugestões de experimentos, ou pedido de experimentos, sobre o assunto que estamos estudando. Minha maior preocupação é com a falta de interesse dos alunos em relação ao conhecimento, com a dificuldade cognitiva de alguns e com o uso de drogas em idades cada vez menores.

Deise elenca as situações que mais a incomodam em sala de aula. Sente necessidade de que os alunos a surpreendam, quando, por exemplo, indo além do conteúdo, sugiram e peçam experimentos. E, mais do que tudo, não questionem a importância do conhecimento 
científico. Faz parte desse incômodo a relação que os jovens estabelecem cada vez mais cedo com as drogas, o que impede que o professor tenha o mínimo controle sobre esse aluno. Sabe que esse problema vai além do desinteresse pela aprendizagem ou de uma dificuldade com ela.

[...] No conselho de classe, por mais democrática que seja a escola, sempre ocorre uma "forçada de barra" por coordenadores ou diretores, para aprovar ou reprovar determinado aluno. No entanto, nas escolas nas quais eu já trabalhei ou trabalho, nós professores apresentamos dados sobre o aluno e opinamos (enquanto disciplina e área) se o estudante tem condições de acompanhar a série seguinte ou não. As discussões podem levar até mais de 1 hora em um caso de provável reprovação (a escola é pequena).Ao final a decisão ocorre por votação.

Quando percebo que nitidamente há uma argumentação em favor desse ou daquele aluno por motivos pessoais (amizade com a família ou para diminuir as polêmicas), me irrito muito. Tenho tido algumas surpresas com alunos nos quais eu votei contra a maioria para reprová-los ou promovê-los. Às vezes o aluno reprovado se empenha muito mais no ano seguinte $\mathrm{e}$, às vezes era o que faltava para ele largar tudo.

Fala sobre a situação de poder que envolve todos os professores, além de quão solitário é decidir o destino dos alunos, sobre a sua aprovação ou reprovação. Nesse momento, ao que tudo indica, todos jogam com o seu poder. Começando pela direção e pela coordenação que, segundo ela, podem forçar a situação para aprovar o aluno dependendo da relação que a família tem com a escola, ou dos problemas pessoais que envolvem aquele aluno.

Deise diz que a reação do aluno à reprovação é imprevisível, já que alguns precisavam viver esse momento crucial para, só então, deslocar-se da posição de apatia e empreender um envolvimento real com a escola; ou podem ocorrer outras situações em que o aluno acabe desistindo de uma vez, ficando por inércia, não se mobilizando em direção a nada que inclua a escola e o conhecimento.

d. Utilização do referencial teórico.

Cenografia: A continuação da cenografia inicial montada por Deise é de uma professora que, apesar de já ter um Mestrado na área de Ensino de Química, acredita que precisa aprender cada vez mais para conseguir gerenciar as situações que a angustiam em sala de aula como: o desinteresse, a indisciplina, o descaso com o conhecimento, etc. Seu desejo é conseguir que o aluno sempre a surpreenda indo além das expectativas. Buscou construir uma imagem de professora que procura cada vez mais o conhecimento sobre o funcionamento da sala de aula e que não suporta que o aluno tenha algum tipo de descaso em relação ao conhecimento científico.

Ethos discursivo: Percebemos a influência e a dívida que ela tem para com o seu pai que lhe mostrou um certo lado lúdico do conhecimento, contando histórias, fazendo 
adivinhações ou contas de cabeça. Tem dívida com a mãe que, embora sofrendo de uma doença ingrata, não fez muitos dramas, se mostrou preocupada com a educação dos filhos e com o próximo quando a incentivava a alfabetizar crianças com menos sorte do que ela. Entretanto lhe foi possibilitado o envolvimento com o conhecimento científico. Situação que se configura inicialmente, com a percepção do poder da ciência, já que levou o homem à lua, mas, ao mesmo tempo, essa nova convicção, de certa forma, parece ter prematuramente quebrado a sua relação com o saber do seu pai. Mostra a importância de ganhar o livro infantil Reinações de Narizinho, pois veio como reconhecimento por ser estudiosa e boa aluna, além de que seus pais não tinham condições financeiras de lhe proporcionar tal tipo de leitura. $\mathrm{O}$ professor de Matemática lhe proporcionou a experiência de ser uma mini professora, fato que, provavelmente, lhe obriga inconscientemente a repetir essa situação, ou seja, precisa mostrar ao aluno o seu conhecimento e, ao mesmo tempo, deseja dele um envolvimento na sala de aula, quase ideal, para que possa, talvez, depositar nele a confiança de que foi alvo. Precisa fazer uma reedição dessas experiências, propiciada pelos modelos que a influenciaram. Aparece a necessidade de cuidar do aluno, de ajudá-lo a aprender e de envolvê-lo com o conhecimento científico e, ao mesmo tempo, uma grande preocupação com a indisciplina que acaba gerando muitas justificativas em busca de encontrar saídas que amenizem o problema. Coloca a busca de solução como sua responsabilidade exclusiva, nos faz inferir que, quando as coisas fogem do controle, a culpa é somente dela. Fala, ainda, sobre o poder de deliberações que o professor e os envolvidos na situação escolar têm sobre o aluno, já que podem decidir sobre sua aprovação ou reprovação numa série específica.

$\mathrm{Na}$ sala de aula, o professor tem o poder de seduzir o aluno para o conhecimento, ou buscar meios de promover essa sedução; ou, até mesmo de criar sanções para os alunos que são inseduzíveis. O que resulta é que o mínimo de critica sobre as suas atitudes faz com que o professor se culpe e se justifique inúmeras vezes.

Resumindo, após a observação das imagens criadas por Deise, e baseados nos elementos que destacamos do seu discurso, podemos inferir que a manutenção da docência acaba se sustentando devido à sua necessidade de manutenção de uma imagem de professora que cuida e se preocupa com os alunos, querendo ver neles algum movimento em direção ao conhecimento científico. Deseja ser surpreendida e quando isso acontece considera-se reconhecida e, muito provavelmente, amada. O conhecimento científico para Deise nos parece ser muito importante, pois considera imperdoável que um aluno questione, ou não deseje, obter esse conhecimento. Pode também estar se sustentando devido à dívida com o pai, com os professores que lhe mostraram as maravilhas da ciência ou com os que reconheceram o seu 
valor. Busca reeditar as situações importantes de sua vida. Culpa-se pela indisciplina, tecendo considerações sobre possíveis atitudes que fossem capazes de minimizá-la. Exerce poder sobre a vida e aprendizagem do aluno em sala de aula, que, depois, acaba sendo confirmado pelos seus pares e pela instituição, nos conselhos finais.

\subsubsection{João}

\section{a. Cenografia}

João, 27 anos, infância pobre. Foi criado em parte pelos avós, em parte pelos tios e, em alguns momentos, pela mãe. Teve duas professoras primárias de quem gostou muito e outras que lhe aplicavam castigos físicos. Nessa fase tinha muitas dificuldades com a Matemática. Da $6^{\mathrm{a}}$ à $8^{\mathrm{a}}$ série supera o medo da Matemática com uma professora que o tratava como se fosse seu filho. No ensino médio profissionalizante não se declara bom ou mau aluno, mas começa a prestar mais atenção nos seus professores. Quando acaba o ensino médio, percebe a dificuldade de arrumar um emprego sem ter experiência, sente-se desamparado e com necessidade de voltar para a escola. Resolve então fazer outro curso profissionalizante na mesma escola pública em que estudou, já que não poderia pagar um novo curso e muito menos um curso pré-vestibular. No principio, os professores estranharam, mas, aos poucos, ele conseguiu incentivo de cinco ex-professores que o ajudaram a mudar diversas situações dentro da escola. O fato marcante que aconteceu foi a formação do grupo de estudos que o obrigava a estudar conteúdos escolares para posterior apresentação aos colegas. Percebe, nessa atuação, que acaba preferindo os conteúdos de Física. Finalmente, entra na universidade pública num curso de Física e hoje é professor na mesma escola onde estudou e tem como colegas os seus ex-professores.

b. Ethos pré-discursivo

João foi um aluno, no curso de pós-graduação, muito participativo e receptivo, que constantemente respondia às perguntas do professor, expressando as suas opiniões sem medo de se expor. É professor na rede pública e aluno regular de Mestrado com um projeto sobre analfabetismo científico, ou seja, quer saber o que nossos jovens sabem sobre ciência. Ele é falante, agitado e tem sempre opiniões para dar. Não suporta muito o silêncio. Quando ninguém responde às questões feitas pelo professor, sempre diz alguma coisa para preencher o vazio. 


\section{c. Análise da História de Vida.}

[...] não procurei ainda me lembrar ou me preocupar com o que passei em minha vida, se isso foi e como foi essencial na escolha da minha profissão e no amor que tenho hoje por ela. A entrada no programa de pós-graduação da universidade tem muito a ver com este amor, mas também tem a ver com a falta de amor que tenho observado em alguns professores. $\mathrm{O}$ amor faz as pessoas acreditarem em um objetivo e lutarem por ele com mais garra. Eu faço Mestrado em ensino de Física porque acredito que posso dar a minha contribuição, pelo menos, onde trabalho. Por isso, faço o impossível para que o meu amor pelo trabalho que eu faço não se acabe. [...]. Até hoje eu tento ser o professor que eu nunca tive nos anos básicos da escola [...].

João acha importante deixar marcado que, para ele, a necessidade de fazer Mestrado surge devido ao amor que tem pela sua profissão e que esse amor ele sentiu falta em muitos dos seus professores. A justificativa por estar fazendo Mestrado, nos parece, vai além de uma conquista pessoal, já que, para ele, a evolução na profissão parece ser uma prova de amor pelos seus alunos. Procura ser um professor melhor do que seus professores do passado, porque precisou de amor e não lhe deram. Observamos, nesse trecho inicial, referências em demasia ao amor que falta, ao que é necessário ou ao que pode ser perdido. O que nos deixa a impressão que essa marca, a da falta do amor, parece ter sido uma constante em sua vida e o que ele quer, na realidade, é que seus alunos não a experimentem. $\mathrm{O}$ amor é colocado, aqui, como elemento que cobre todas as faltas, ou seja, que é capaz de fazer o sujeito se mobilizar na busca de realizar seu desejo.

[...] lembro muito bem é das minhas professoras do pré: Elô e Dinah. [...] foram, sem sombra de dúvidas, as professoras que mais acreditaram que eu tinha um papel muito importante na sociedade. Isso elas falavam para todos os seus alunos, sem exceção, mas me pareceu que era diretamente pra mim que elas falavam.

[...] até que minha mãe apareceu na história. Até então eu não vivia com a minha mãe, mas sim com meus avós e tios. Minha mãe me deixara com três meses de idade e, mesmo a conhecendo, nunca se mostrou entusiasmada para morar comigo.[...].

A preocupação principal de João nos parece, foi encontrar um lugar no mundo e essas duas professoras lhe mostraram essa possibilidade, isto é, indicaram a chance desse lugar existir. No segundo parágrafo podemos perceber porque ele faz tanta referência, nas primeiras linhas do seu texto, à falta de amor, pois foi criado pelos avós e tios, que, aparentemente, não conseguiram preencher totalmente essa falta de amor. Se levarmos em conta que a mãe o abandonou com três meses de idade e, mesmo tendo contato com ele, 'nunca se mostrou entusiasmada' em assumi-lo, a escola parece se mostrar como o lugar que resta para obter alguma forma de satisfação emocional, de aceitação ou até mesmo de amor.

No trecho em que ele faz referência à entrada da mãe na história: 'até que minha mãe apareceu na história', são momentos em que acredita que alguma mudança vai acontecer, como veremos abaixo. A mãe o requisita para morar com ela, mas ele continua não 
encontrando o amor que ele está procurando, pois o que ela lhe proporciona são novos maus tratos.

Fui para a primeira série com sete anos em uma escola pública [...] conheci a nova professora (ou deveria chamar repressora), a dona Laura. Esta foi totalmente o oposto das primeiras, pois foi a primeira professora que eu tive, que ensinava literalmente "na marra". Ela era extremamente severa, nós estávamos saindo da ditadura, mas ela ainda permanecia lá. Minha orelha queimava, pelo menos, duas vezes por semana por causa da minha letra (que nunca foi assim um primor) e da Matemática. Lembro-me de ter levado duas pancadas de palmatórias na mão: uma por causa da Matemática e outra por causa de um beijo que eu dei em uma menina: Adriana. Apanhei de novo da minha avó, pelo mesmo motivo.

Quando começou o segundo ano, pensei que havia acabado tudo, mas peguei a dona Laura novamente como professora. Que lástima!!! Apanhei o ano inteiro novamente

[...] No ano seguinte aconteceu o que eu já não estava mais esperando: minha mãe me levou para morar com ela [...] Na nova escola, conheci outra professora carrasca: Dona Aida. Ela com a minha mãe faziam um par perfeito: eu apanhava da professora na escola e da minha mãe em casa. Culpa de quem? Maldita Matemática. Aprendi a tabuada na pancada. Até hoje eu me lembro do 8 × $8=64$. Minha mão dizia que era um número graaaaaaannnnnnnde e cada vez que ela fazia isso, uma das mãos dela vinha em direção ao meu rosto. E ai de mim se eu desviasse: eram duas pancadas que eu levava. Assim foi passando minha terceira e quarta séries.

Conta que sofreu muito nessa fase, porque os professores castigavam fisicamente os alunos, a professora puxava as orelhas e dava bolos de palmatória e, como se já não bastasse, havia as surras em casa. O maior problema que o acompanhou, nesses anos iniciais na escola, parece ter sido a sua relação com a Matemática.

A frase que coloca antes de anunciar que vai morar com a mãe: 'aconteceu o que eu já não estava mais esperando', mostra o quanto ele esperou, ou desejou estar com sua mãe. Não sabemos exatamente qual a expectativa que ele tinha com essa relação, mas percebemos que, qualquer que tenha sido, só teve um resultado: mais frustração e falta de amor.

Nova mudança de escola, nova adaptação [...] Meu medo de Matemática acabou, com a vinda de uma professora que foi diretamente essencial na minha formação. A professora Rosa foi quem realmente me ensinou Matemática de uma forma muito mais prazerosa que as professoras que eu havia tido anteriormente. Ela era paciente, carinhosa, amável e tinha uma maneira de ensinar muito mais eficaz. Hoje sinto um prazer enorme em trabalhar com ela na mesma escola.

A situação em que o professor tem que ter amor pelo que faz, e pelo aluno, parece ganhar força no seu discurso porque, aqui, ele nos mostra, através dos atributos que elenca para essa professora, qual a razão do seu medo da Matemática ter desaparecido: novamente ele estava começando a encontrar o amor que procurava. Destaca, ainda, o fato de trabalhar, hoje em dia, com ela na mesma escola e há, aqui, um certo prazer em se manter ligado a esse personagem da sua história. 
Ensino médio I e II: minha destruição e minha recriação.

Sei que este título parece uma coisa meio fúnebre e meio confusa, mas foi assim que eu me senti no ensino médio. Fiz duas vezes o ensino médio, dois cursos técnicos, um de administração de empresas, o qual terminei em 1993 e um de contabilidade básica, que terminei em 1997, quando entrei na Universidade. De 1991 a 1993 fiz um curso de administração de empresas bem básico, onde a maioria dos meus professores não conseguiam nos fazer aprender muito bem. Minha formação não foi puxada para o lado do raciocínio (só fui aprender a raciocinar direito em 1995, quando voltei à escola para fazer novamente o ensino médio), portanto tinha muitas dificuldades em aprender.

[...] Nenhum dos meus professores soube ser convincente naquilo que fazia. Sem contar que depois eu fiquei sabendo que alguns destes professores estavam lecionando a matéria que eles não tinham formação. Este foi o caso de um professor de estatística básica que tive neste curso. Só depois que eu soube que ele era mestre em Biologia pela USP. Perguntei-me: "o que ele está tentando fazer ao dar aula de estatística?".

João nos mostrou a importância do ensino médio profissionalizante na sua vida, pois a segunda experiência ajudou-o a se recriar e a aprender a raciocinar. É muito crítico em relação a alguns dos seus professores, especialmente quando narra sobre dois aspectos que o incomodaram muito: o fato de que nenhum 'dos meus professores soube ser convincente naquilo que fazia' e 'alguns destes professores estavam lecionando a matéria que eles não tinham formação'. Percebemos que, devido a esses professores se mostrarem inseguros ou incompetentes na transmissão do conteúdo, João firmou sua crença na hipótese de que a formação específica é vital para o professor, porque ele só se sairá bem se ministrar conteúdos para os quais é habilitado. Portanto, ele atribui a dificuldade que o professor teve em mostrar competência à falta de domínio dos conteúdos específicos.

Me formei (pela primeira vez)em 1993 e, agora com um diploma nas mãos, o que seria da minha vida??? Minha mãe havia me deixado novamente; (eu) estava morando com meus tios, mas com a perspectiva de arrumar um emprego na área de administração.

Doce ilusão!!! Todas as empresas que eu visitava queriam pessoas que já tivessem pelo menos, um ano de experiência. Eu tinha dois, mas no estágio, mais nada. Veio a idade de me alistar no exército, o que esvaiu todas as esperanças que eu tinha de arrumar um emprego na área. Isso foi 1994, ano de eleição para governador do Estado de São Paulo. Então eu comecei a trabalhar para um partido político, colando cartazes nos postes à noite. Como foi a única coisa que eu tinha achado para mim, entrei de cabeça neste emprego.

João vai morar com a mãe que o abandona novamente fazendo com que, dessa vez, ele vá morar com os tios. Após a formatura, ele se viu, como muitos estudantes, com o diploma, sem experiência e sem emprego. Deixa transparecer a preocupação que tinha em relação a cuidar de sua própria sobrevivência e, como, com a chegada da época de alistamento no exército, tudo fica mais difícil, indo pregar cartazes para um partido político, pois tinha que cuidar de si mesmo.

Em 1995 comecei a estudar novamente. Muitos professores que já haviam me dado aulas [...] me falavam "O que você está fazendo aqui de novo? Isso não é mais pra você. 
Procure fazer outra coisa". Ou então "Enchendo o saco de novo aqui? Vai procurar sua turma!!!”.

Mas, o que estas pessoas não sabiam é que eu estava dando o passo mais decisivo da minha vida. Foi aí onde eu conheci os cinco professores que mais me apoiaram na empreita de prestar um vestibular, [...]

Nesta época houve uma pessoa que estava pensando em montar um Grêmio estudantil. Me juntei com essas pessoas, contatamos uma entidade estudantil e arrumamos uma grande e barulhenta briga com os diretores da escola. [...] Eram verdadeiros ditadores e nós tivemos muitos problemas para fazer com que eles nos deixassem [...] arrumar a biblioteca da escola (que nós só conseguimos com a ajuda desses cinco professores), arrecadar livros para essa biblioteca e fazer um grupo de estudos aos sábados, para que algumas pessoas pudessem entrar na Universidade.

Com muito custo nós conseguimos que a direção da escola nos deixasse fazer o grupo de estudos aos sábados. Para isso, um destes cinco professores, Francisco, de História, teve que se candidatar para o cargo de coordenador pedagógico e fazer um projeto, homologar este projeto na $\mathrm{DE}^{14}$ e mandar para a Secretaria da Educação. Este projeto foi o maior responsável por eu ter entrado numa universidade pública.

João narra sua segunda experiência escolar e mostra a reação dos seus antigos professores em relação à sua volta à sala de aula. Parece ter sido muito importante para ele dar uma resposta a todos, mostrando a possibilidade de recriação que ele teve e que foi capaz de dar os melhores resultados. O que acabou acontecendo foi uma nova chance de envolvimento com alguns professores, que possibilitou maior responsabilidade com a própria aprendizagem. Tornou-se mais seguro porque conseguiu, junto com esses professores, criar uma nova relação com o conhecimento. Pôde interferir na gestão da própria escola, realizar melhorias e, ao mesmo tempo, ajudar outros alunos na busca de um curso superior. Ele se tornou a prova do resultado desse esforço, já que essa experiência lhe permitiu finalmente ingressar numa universidade pública. Logo, aqueles professores que criticaram a sua volta tiveram que fazer uma atualização do olhar que tinham sobre ele.

[...] uma pessoa que me ajudou na escolha desta profissão foi uma professora de Educação Artística que tive, a professora Eliana. [...] que realmente gostava daquilo que fazia. Era a professora que cuidava de seus alunos como se fossem seus próprios filhos [...] Mais tarde, quando eu entrei na Universidade, ela foi a única pessoa dessa época que me cumprimentou, dizendo que já sabia que eu me daria bem em qualquer coisa que eu escolhesse na vida.

Ele destaca, como responsável pela sua entrada na profissão, a professora que " cuidava de seus alunos como se fossem seus próprios filhos”. Pelo que já conhecemos de João, sabemos que ela conseguiu atingir seu ponto nevrálgico com as suas atitudes. No discurso dele aparece uma relação sutil entre o fato de ela gostar do que fazia e de tratá-los como se fossem seus próprios filhos. Isto nos remete ao inicio do seu texto, onde ele nos fala do amor pela profissão e pelo aluno como se fossem vitalmente ligados. Podemos, então,

\footnotetext{
${ }^{14}$ DE - Diretoria de Ensino.
} 
imaginar o efeito que teve sobre João o fato de essa professora ter sido a única a cumprimentá-lo quando entrou na universidade pública e ainda fazer a afirmação de que já sabia que teria sucesso em qualquer coisa que ele escolhesse na vida. Essa crença nas suas possibilidades de sucesso nos remete às suas duas professoras da pré-escola, que foram as primeiras a verbalizarem a possibilidade de que ele tivesse um lugar no mundo.

Nunca gostei de história na minha vida. [...] Mas o Francisco não. Este professor era diferente. Ele ensinava com gosto. Não era o gosto pela escola, mas sim pelos alunos e foi isso que me fez gostar do seu jeito de lecionar. Foi a primeira vez que eu aprendi história decentemente.

O Luis também tinha o seu diferencial, apesar de eu não conseguir entender nada de Física que ele me ensinava. Não é à toa que eu prestei para química na primeira vez. Mas, depois do primeiro ano que eu prestei o vestibular (e não passei), fui me aproximando mais da Física. [...] o Luis que era tecnólogo na sua formação, entrou na $\operatorname{USP}^{15}$ para fazer um curso de Licenciatura. Segundo alunos amigos meus que estavam tendo aula com ele, ele estava melhorando muito seu método de ensino. Por isso eu me empolguei mais ainda para fazer um curso de licenciatura na USP e estudei bastante para isso.

Sempre admirei estes (dois) professores (Francisco de História e Luis de Física). [...] Hoje nós trabalhamos juntos na mesma escola que ele me deu aula. Estas foram as pessoas que me inspiraram a fazer um curso de licenciatura.

Dos cinco professores com quem ele estabeleceu relações na sua segunda entrada no colegial ele destaca dois, como responsáveis na sua escolha pela licenciatura. Acompanhamos o discurso que ele elaborou para os dois professores e pudemos verificar que o professor de História conseguiu status junto a ele principalmente porque ensinava com gosto, não gosto pela escola, mas pelos alunos.

Aqui nos parece que João reafirma a relação direta, de amor, que deve existir entre o professor e o aluno. Quando percebe que o professor tem um envolvimento amoroso com os alunos, ele se envolve também com o conteúdo. O professor de Física que, na primeira vez que tinha sido seu professor, não tinha deixado marcas, tanto que ele prestou Química, só vai ter esse poder de marcá-lo quando ele, que era tecnólogo, vai fazer licenciatura em Física. Nessa situação, ele volta a reafirmar sua crença de que é necessário um conhecimento específico para se ensinar algo, pois as aulas desse professor melhoraram muito depois que foi fazer licenciatura em Física.

$\mathrm{Na}$ finalização dessa situação ele mostra o orgulho e a importância de estar trabalhando com esses professores na mesma escola, o que nos ajuda a inferir que, para João, o lugar que está procurando parece ser o de se colocar em situação de igualdade com os seus modelos. A professora de Artes agora é sua colega, os professores que ele mais admira, também e, como quase todos já são pós-graduados, ele sente-se impelido a também cumprir

\footnotetext{
${ }^{15}$ USP- Universidade de São Paulo
} 
essa etapa. João presta contas aos seus professores, que talvez perceba como uma família e, por esse motivo, não consegue se desligar, procurando estar sempre junto e seguir seus passos.

Minha formação foi um misto de espelho dos meus antigos professores e agora amigos [...]. Hoje sou um professor de Física que acredita nos meus alunos e não deixo que nenhum deles caia na besteira de não acreditar que são capazes de fazer um curso em qualquer faculdade pública. É muito provável que uma das minhas alunas de suplência preste vestibular, pois eu e outros professores estamos incentivando e ajudando muito esta menina.

Ele busca no modelo desses professores, a quem presta contas, um motivo para evoluir. Acredita que ele é resultado dessa influência e se preocupou em encontrar um lugar ao lado desses seus modelos. Assim como conseguiu o crédito deles para ir adiante, ele se preocupa em incentivar seus alunos a seguirem o mesmo exemplo. Portanto, parece estar retomando sua história, na medida em que se preocupa em incentivar os alunos a buscarem os seus sonhos, mas, ao mesmo tempo, não desejando que eles passem pelos momentos de indecisão e falta de amor que ele passou.

d. Utilização do referencial teórico.

A cenografia: Aqui aparece complementada a cenografia montada por João, que começa quando ele é abandonado pela mãe e criado pelos avós e tios. Inicialmente, sente-se acolhido pelas professoras da pré-escola, que lhes mostram como ele pode fazer a diferença. Depois de algum tempo, vai morar com a mãe o que ocasiona uma mudança de bairro e escola; aí é abandonado novamente por ela e volta a morar com os tios. Apanha muito quando é criança, em casa, e na escola principalmente, porque tem muitas dificuldades com a Matemática. Essas dificuldades só são superadas, posteriormente, com uma professora que trata aos alunos como se fossem seus próprios filhos. Termina o ensino técnico e se vê com diploma, sem emprego e sem experiência e, como se não bastasse, em ano de alistamento militar. Sem alternativas, volta à escola para fazer um novo curso técnico; encontra uma nova ordem para o seu relacionamento e aprende muito ajudando na criação de um centro acadêmico e de um grupo de estudos, que lhe possibilita entrar numa universidade pública. Hoje, trabalha na mesma escola em que seus ex-professores. Percebe-se, aí, a montagem de várias cenografias.

Ethos discursivo de uma pessoa que consegue vencer inúmeras dificuldades familiares, mas não desiste; sai em busca de conseguir algum tipo de relação que preencha essa falta. Encontra eco a esse desejo nos professores que acreditaram num possível futuro de sucesso para ele. Coloca o seu amor à profissão como uma necessidade de evolução, cria a 
imagem de professor ideal, então, a sua entrada na pós-graduação é vista como um ato de amor, já que, para ele, a escola parece ser substituta de algum papel da sua vida emocional. Cria o estereótipo de vencedor, porque valoriza, na sua história, as dificuldades e o sofrimento até a vitória. Inicialmente, deixa transparecer a imagem de uma pessoa que teve que se submeter a situações sobre as quais ele ainda não podia ter controle, não podia escapar, devido aos problemas com a mãe e com a escola. Mas, aos poucos, vai vencendo as dificuldades e se auto-afirmando como 'alguém que tem um lugar no mundo'. Então, criou um ethos de uma pessoa que foi capaz de evoluir a partir da criação de um lugar em que as relações e os desejos se tornaram possíveis.

Cria o ethos de quem acredita que o aprendizado modifica as pessoas e que um curso específico é capaz de melhorar a performance do professor; que a sua capacidade profissional melhora quanto mais se especializa e, para justificar isso, utiliza o modelo de seus professores e cola no desejo deles, fazendo do desejo deles o seu.

Conseguiu um lugar e, daí, procura agir com coerência incentivando, ou seja, pagando a sua dívida, provendo aos seus alunos a oportunidade que lhe foi dada. Os modelos que o influenciaram e que pareceram mais decisivos na sua escolha profissional foram os professores dos cursos técnicos e, aparentemente, ele toma como objetivo de sua própria vida as decisões profissionais desses professores. A marca que ele pretende deixar em relação ao conhecimento científico, aparece em sua história na forma de um questionamento sobre a incapacidade de envolver e apaixonar o aluno quando os professores não têm uma formação específica. Pauta-se em seus professores que só conseguiram envolvê-lo após um aprimoramento e, por conseqüência, a obtenção de maior segurança com os conteúdos. A outra marca diz respeito ao amor que ele considera necessário ao exercício da profíssão do qual sentiu falta durante grande parte de sua vida e de sua escolarização.

Resumindo, podemos inferir, após a observação das imagens criadas por João que ele acreditou nas boas previsões que foram feitas sobre o seu futuro e, devido aos problemas pessoais, se ligou a professores que poderiam substituir, de certa forma, essa falta de amor e cuidado que não tinha tido quando criança. Um outro tipo de relação se consolida com a experiência da segunda entrada no colégio técnico, já que, além do aprendizado, começa a ter uma relação mais segura com os seus modelos. Adquire confiança no seu poder de aprender e resolver situações, começa a acreditar na sua capacidade intelectual e, finalmente, busca estudar em uma universidade pública. O coroamento dessa relação se dá com o fato de que, até hoje, convive com esses professores como colegas, na mesma escola. Ele esteve preocupado com a construção da imagem de uma pessoa que venceu sozinha as adversidades 
e que foi atrás das oportunidades, fazendo as escolhas certas. Quanto piores forem as condições iniciais, mais valorizada, nos parece, deve ser a chegada ao final.

Quanto ao aspecto, sustentação na docência, podemos inferir que isso pode estar se dando devido a influência e confiança depositada pelos seus professores, em relação ao seu futuro. A segunda graduação coloca João numa nova relação com os seus professores, em situações em que foi considerado como um companheiro na busca de soluções para a escola e para o futuro dos alunos, inclusive o dele. Quer conduzir seguramente, sem sofrimento, o aluno, através dos conteúdos, porque acredita que o conhecimento científico é capaz disso, e que o amor e a confiança, que quer despertar neles, farão o resto, conduzindo-os em segurança ao sucesso. Então, devido ao fato de ter obtido esse algo, amor e um lugar, que nunca conseguiu na família, sente a necessidade de cuidar, ajudar e acreditar nos seus alunos.

Sempre quis ser cuidado e amado, do jeito que lhe foi negado na infância. Estar com os alunos em sala de aula é uma possibilidade de conseguir esse amor. Tem um certo prazer em descrever as situações difíceis, pelas quais passou em sua vida, além de retornar a essas dificuldades a todo o momento no seu discurso, elas aparecem envoltas em expressões e situações que buscam sempre nos remeter ao riso.

\subsection{CONSIDERAÇÕES SOBRE AS HISTÓRIAS DE VIDA.}

Trazendo para a análise o corpus, utilizando os conceitos de Maingueneau (2005), observa-se que há uma cena englobante, onde encontramos a cenografia construída e as várias cenas que a compõem. Podemos observar as várias imagens criadas e que querem ser validadas na narrativa de cada autor. Aspectos importantes aparecem no discurso dos pesquisados durante a construção de suas Histórias de Vida que, de certa forma, fazem parte das imagens que eles acharam importantes construir para a justificação da sua entrada na docência.

O corpus analisado nos mostrou através do ethos discursivo que os pesquisados se empenharam em construir uma imagem com valores humanos, sociais e éticos. Na construção dessa imagem fizeram o possível para serem agradáveis em suas histórias, contando os principais eventos de sua vida, algumas vezes levando o texto para o lado do humor. Nessa empreitada, provavelmente, corrigiram suas histórias nos pontos negativos buscando obter a nossa confiança nos seus bons propósitos como professores e, portanto, com o aluno, tentando sempre apresentar argumentos de coerência nelas. 
O discurso que os narradores fizeram encerraram inúmeras imagens, pois eles estavam preocupados em passar imagens de si, cheias de valores morais e éticos, no que diz respeito às suas escolhas, suas vidas e suas atitudes em sala de aula. Com certeza, eles gostariam de construir uma imagem melhor ainda, principalmente pelo fato de acreditarem que a pesquisadora tinha expectativas em relação aos discursos que fizeram sobre a profissão docente. Portanto, construíram os discursos levando em conta os fatores sobre suas vidas e práticas: como eles a vêem; como gostariam que fosse; como imaginam que a pesquisadora veria; como gostariam de serem vistos e assim por diante.

Olhando para o ethos discursivo construído, mesmo dentro da singularidade de cada história e, com a prevalência de alguns aspectos em um discurso mais do que em outros, pudemos marcar alguns dentre esses ethos discursivos que, provavelmente, dizem respeito ao que mantém o sujeito na profissão docente. O ethos da dívida é mostrado quando discursa sobre modelos que o influenciaram na escolha da profissão, ou pessoas que, de alguma forma, o apoiaram ou apostaram no seu futuro, destacando-se os pais e professores. Quando, nos seus relatos, levam o foco para a influência que sofreram, de certa forma, estão prestando contas do que fizeram em função do apoio e apostas recebidas e, nos parece, remetem a algum tipo de dívida.

O ethos da marca, sendo que essas marcas foram traduzidas na nossa interpretação como: a necessidade que o professor tem de que o aluno estabeleça uma relação marcante com o conhecimento científico, que sigam profissões que os envolvam e, assim, possam ser, de alguma forma, sucessores desse conhecimento; a necessidade que o professor tem de provocar mudanças e fazer diferença na vida e na escolha dos alunos, pois querem cuidar e orientar os seus alunos na vida. Aparece o ethos de gratidão, que se configura numa espera permanente de reconhecimento do seu trabalho; ele quer ser reconhecido na rua, abraçado, quer ser respeitado como competente, quer ser visto como amigo pelo aluno e, principalmente, não ser esquecido e sempre ser amado. Esse reconhecimento é esperado também dos pais dos alunos e, ainda, da instituição. Tem confiança na sua atuação e cria um ethos de controle, pois se considera capaz de criar e dominar uma situação de aprendizagem. A sua preocupação com o melhor para o aluno faz com que organize os conteúdos da melhor maneira possível para que este se sinta seguro durante a aprendizagem; portanto, não quer repetir as situações difíceis que aconteceram em sua vida, quer cuidar para que os alunos tenham um caminho sem sofrimento.

Surge, finalmente, o ethos de justificação, isto é, aparece no seu discurso uma necessidade de fazer justificativas, que se repetem em várias situações, da vida ou da sala de 
aula, sobre o fato de que não consegue obter o sucesso esperado e se culpa. Essas culpas e justificativas sempre surgem quando é colocada em questão a imagem ideal de professor, que provê tudo e que sabe tudo sobre a relação, o ensino e a aprendizagem.

Diante dessa análise, percebemos que é possível identificar nas histórias alguns aspectos referentes às cenografias que foram montadas, os ethos pré-discursivos e discursivos e, até mesmo, os estereótipos que deixaram transparecer quando nos falaram sobre suas trajetórias profissionais e os eventos que as marcaram.

Conseguimos reunir, nos ethos construídos, alguns aspectos que se repetiram no discurso dos pesquisados, os quais, apesar da singularidade, nos parecem indubitavelmente relevantes para se pensar a situação da permanência da docência.

Os ethos discursivos, em particular, trouxeram alguns elementos que podem ser sistematizados com base em determinadas demandas ${ }^{16}$ dos professores. A palavra demanda está aqui sendo utilizada como forma de expressão de um desejo do sujeito, um apelo que ele faz ao outro quando quer obter deste alguma coisa. Assim, os elementos que foram sendo sistematizados, nos remeteram a algumas demandas que os professores fazem a diferentes outros. Quando, em diversas ocasiões, os professores fazem referência aos pais, ou aos professores que tiveram, parecem, de alguma forma, estar prestando conta a eles e, ao mesmo tempo, esperando que o pagamento de alguma dívida seja por eles reconhecido. Nesse sentido é que afirmamos: quando os professores se remetem a todos esses personagens de suas histórias, o fazem pedindo a esses outros ${ }^{17} \mathrm{o}$ reconhecimento de seus esforços em tornar-se aquilo que imaginam fosse esperado deles. Isso, inclusive, fica ainda mais evidenciado na necessidade que manifestam em ter seu trabalho reconhecido, seja pela instituição, seja pelos pais ou pelos alunos. De forma análoga, a necessidade de fazer marcas, também nos parece um pedido que o professor faz aos seus alunos de que se formem à sua imagem e semelhança, isto é, os professores querem que os alunos sigam profissões que envolvam os conteúdos que lecionam. Essa necessidade de marcar com o conhecimento científico diz respeito à repetição da situação que o professor viveu influenciado pelo seu próprio professor, ou quando lhe foi possibilitado esse acesso ao conhecimento pela família, ou por qualquer outra pessoa.

A busca de um controle quase que absoluto sobre a condução das práticas de sala de aula, também é interpretada por nós como uma demanda, porque quando os professores se colocam como capazes de criar e de dominar os processos de ensino e de aprendizagem e,

\footnotetext{
${ }^{16}$ demanda - é a articulação significante na qual devemos escutar o desejo como além da demanda. Em Psicanálise não significa responder, mas sim aportar algo a mais, já que não é apenas uma questão de 'necessidade'.

${ }^{17}$ outro - identificação narcísica com a imagem do semelhante, do pequeno outro.
} 
ainda, de evitar a repetição de situações desagradáveis que aconteceram em sua vida escolar, nos parece que estão pedindo aos outros que lhes concedam o privilégio de exercer esse controle. Só assim os bons resultados sobre os cuidados com o aluno podem aparecer. Essa busca pelo controle da gestão de sala de aula se evidencia, inclusive, nas longas justificativas dadas pelos professores para explicar qualquer imprevisto, bem como no sentimento de culpa que aparece quando o professor tenta justificar aquilo que considera como uma atuação falha. Essas justificativas também estão relacionadas às demandas, porque existe a necessidade de manter uma coerência interna sobre a imagem que ele tem e projeta de si.

Ao lado dessas considerações, nos chamou a atenção o fato de que todos os professores pesquisados não destacaram, explicitamente, em suas produções discursivas, questões referentes ao conhecimento científico, isto é, a relação que eles mantêm particularmente com esse conhecimento. Apesar disso, pudemos perceber implicitamente em seus discursos essa importância quando pretendem criar alunos sucessores desse conhecimento; seja em profissões ligadas a ele, seja na facilidade de utilização da linguagem científica ou, até mesmo, na crença de que o conhecimento científico específico é necessário para ensinar esse conteúdo com sucesso. Essa omissão nos parece ter acontecido devido ao tipo de questões e situações que o professor foi solicitado a responder. Mas, pelas interpretações que fizemos, pudemos considerar que essa relação com o conhecimento científico perpassa provavelmente todos os elementos possíveis de sustentação na docência.

$\mathrm{O}$ que os professores escolheram contar sobre sua trajetória profissional nas Histórias de Vida foi, basicamente, relações que giram em torno de um compromisso que eles próprios parecem ter assumido com diversas instâncias e, em suas opiniões, estão envolvidas com o sucesso na condução do processo educativo. Nos perguntamos, então, qual a natureza desse compromisso e o que poderia estar subjacente a ele a ponto de marcar tão fortemente a maneira com a qual os professores contam histórias sobre sua vida profissional.

No entanto, não conseguimos encontrar uma resposta a essa questão com base nos dados trazidos pelas Histórias de Vida. Além disso, a Análise do Discurso orientada por Maingueneau (2005) não nos permite avançar na direção pretendida, pois não nos oferece condições de compreender o que pode estar subjacente aos elementos que aparecem de forma recorrente nos discursos. Por esses motivos, realizamos também entrevistas com esses quatro professores indo buscar um novo referencial de análise que fosse mais promissor com as nossas expectativas de pesquisa. 


\section{AS ENTREVISTAS}

Neste capítulo, após a leitura e organização das entrevistas, faremos considerações sobre os aspectos que nos permitiram avançar em relação aos dados obtidos inicialmente com as Histórias de Vida e explicitaremos porque se faz necessária a escolha de um novo referencial que permita olhar, de maneira mais subjetiva, os dados.

As entrevistas trouxeram à tona elementos sobre os sujeitos, com certeza mais detalhados, mas que apenas corroboraram os dados já interpretados com as Histórias de Vida. A dinâmica que seguimos foi a de buscar nas entrevistas uma possível ampliação na nossa compreensão, pois elas repetiram muitas situações já descritas pelo entrevistado na primeira coleta de dados, optamos então por analisar utilizando fragmentos mais curtos evitando repetição em demasia.

Podemos dizer, então, que a essência da história do sujeito na construção do estereótipo de professor ideal nos foi revelada, em parte, por esse seu contar e recontar de sua trajetória profissional inicialmente nas Histórias de Vida e, posteriormente, nas entrevistas semi-estruturadas. Esses aspectos reencontrados nos permitiram fazer inferências mais seguras sobre o que pode estar sustentando o sujeito no exercício da docência.

\subsection{ANALISANDO AS ENTREVISTAS}

Para organizar a análise, reunimos as situações que nos chamaram a atenção nas entrevistas em quatro grupos, que foram exemplificados com pequenos fragmentos do texto, para que, finalmente, pudéssemos empreender uma interpretação.

No primeiro grupo de situações das entrevistas reunimos dois tipos: as que contavam sobre os conhecimentos que o professor desenvolveu com a sua prática sobre o aluno, sobre a sala de aula e sobre a relação entre eles; e as que descreviam situações difíceis de relacionamento e aprendizagem. Interpretamos que, nesses momentos, o professor está querendo falar sobre um saber que adquiriu com a prática. Esse saber sobre como ter sucesso nessas situações parece torná-lo seguro porque acredita que seus esquemas de controle sobre o aluno, sobre o conhecimento e sobre a relação, irão funcionar e lhe conferir o poder e a esperança de solucionar todos os impasses conseguindo, assim, êxito na aprendizagem. 
[...] peguei uma turma legal e naquele dia eu descobri [...] quando eu tô com medo eu aviso tô insegura [...] faço uma brincadeirinha e se eles dão um sorriso pra mim eu me sinto em casa e aí a coisa flui normal... [...] no primeiro ano você percebe que o babado não é o conteúdo não, que o negócio é você olhar no olho do aluno, essa interação, né... que o conteúdo, claro você tem que ter um domínio [...] mas você vai aprendendo também [...] que você precisa que o aluno esteja com você senão você se sente à lousa, né![...] acho que isso foi um caminho que eu descobri que é esse jeito bem humorado de passar o conteúdo (Madalena).

[...] (o professor) trabalha intimamente com pessoas que no meu caso tão em formação, eu acho que forma muito caráter nesta época, muito de personalidade [...] é alguma coisa meio que privilegiada. Além de mexer com o conhecimento, que é o saber, [...] tem o emocional [...] porque o adolescente [...] é tudo, tudo... é sentimento... ele odeia[...] (Maria).

[...] uma turma pesada de escola pública noturno, muitos viciados fedendo maconha e eu muito novinha [...] aí eu consegui meio que entrar na deles falando um pouco de música, de rock, coisa que eu nem curto [...] e eu ganhei a turma com isso [...] (Deise).

Madalena relatando sobre o conhecimento que tem sobre a sua relação com o aluno, nos conta sobre a estratégia que utilizou, quando se sentiu insegura no primeiro dia de aula, e que continua utilizando até hoje com turmas novas. Esta estratégia se baseia em assumir, para os alunos, as suas dificuldades, dizendo que pode não estar sendo eficiente no ensino daquele conteúdo e finalizando com uma brincadeira. Se conseguir angariar sorrisos, significa que a estratégia, o seu jeito bem humorado teve êxito e os alunos estão praticamente conquistados.

Maria fala sobre a responsabilidade em trabalhar com pessoas em formação porque é necessário um conhecimento sobre o funcionamento do adolescente, além de um saber sobre como administrar o seu lado difícil. Só então poderá pensar em promover alguma relação dele com o conhecimento.

Deise nos fala sobre o saber que desenvolveu no seu primeiro contato com os alunos. Pois percebeu que é necessário encontrar um jeito de fazer uma ligação, ou seja, um jeito de envolver e comprometer o aluno com a sua aprendizagem, nem que, para isso, seja necessário fazer um pouco o jogo dele.

Reunimos, agora, no segundo grupo, situações em que o professor tem o poder de diagnosticar os momentos em que teve sucesso ou insucesso no que diz respeito à aprendizagem e comportamento do aluno. Percebemos que, após diagnosticar a situação de aprendizagem e tecer juízos e explicações sobre ela, passa a viver um momento em que esse aparente poder e controle sobre o ensino e o aluno acabam se transformando em culpa. Isto acaba ocorrendo porque, apesar de todas as previsões feitas e de todas as justificativas coerentes que o professor venha a elaborar para explicar o que poderia acontecer ou não, o que resta é que as suas tentativas de controle, via de regra, não resultaram em sucesso. 
[...] Acabou tudo se ajeitando, mas eu acabei me demitindo de lá porque achava que eu não estava sabendo lidar com esse descaso [...] embora você encontre várias justificativas para aquela situação ruim ter acontecido no fundo você se sente de alguma forma culpado e no fundo você se sente de alguma forma profundamente rejeitado e isso incomoda [...] eu me culpo demais, é muito difícil eu achar que a classe é uma porcaria, né, eu posso até falar isso, mas quando eu vou voltando pra casa, eu falo: onde é que eu estou errando? (Madalena)

[...] ele passou pela minha mão e não ficou melhor do que ele era antes [...] Eu não quero judiar, eu quero formar [...] Então eu sinto que eu não tenho mais... eu eu eu tenho medo de não apostar numa sala novinha como essa, entendeu? [...] (Maria).

[...] agora o problema da indisciplina é um problema meu que me atrapalha [...] quando eu não consigo fazer com que a classe fique envolvida [...] eu fico muito frustrada [...] acho que eu era mais empolgada [...] eu acho que eu devia ler mais [...] A gente sempre fica imaginando no começo do ano vou fazer tal coisa projeto [...] mas o tempo vai passando e agente vai deixando a coisa. (Deise)

Madalena conta sobre uma situação ruim que aconteceu em sua sala de aula e diz como foi difícil suportar o descaso de alguns alunos em relação à sua pessoa; que, por mais razão que ela tenha tido no impasse que se instaurou naquela sala, sente-se culpada e responsabilizada pelo insucesso porque se sentiu profundamente rejeitada. Diz que pode até culpar os alunos pelo não aprendizado, mas, depois, sozinha com suas considerações, se martiriza em busca de novas estratégias e dos seus próprios erros.

Maria conta que, se foi professora de um determinado aluno, ele tem sempre que ser uma pessoa melhor, não pode passar pela sua mão e não ter mudado para melhor, pois, caso isso aconteça, ela sentir-se-á culpada. Não quer maltratar o aluno, não quer puni-lo, só quer ajudá-lo com o conhecimento, mas, devido à situação que vivemos atualmente no ensino, tem sempre que estar ameaçando-os para que realizem as tarefas. Culpa-se por estar deixando o ensino médio e se aposentando, apesar de que continuará sendo professora no ensino superior. Mas, como já contou em sua História de Vida, no momento, sua maior culpa é por não ter energia para investir nos alunos da oitava série e, principalmente, nas atividades em que é solicitada pela escola.

Deise finaliza esse fragmento culpando-se pela indisciplina na sala de aula. Acredita que isso acontece por não conseguir manter os alunos envolvidos. Acha que deveria voltar a ser uma pessoa empolgada, deveria ler mais, estudar mais e ainda dar conta dos planejamentos do começo do ano letivo.

Reunimos, no terceiro grupo, situações que aparecem em vários momentos tanto nas Histórias de Vida como nas entrevistas e que dizem respeito à influência dos pais, professores ou até mesmo de outras pessoas no caminho da profissionalização. Parece-nos que, como já interpretamos, essa influência e crença no sucesso do caminho que ele percorreria, se configuram numa dívida, a qual ele está sempre preocupado em saldar. 
Optei por química simplesmente porque a professora de química do ensino médio era excepcional [...] tinha uma capacidade de nos encantar com a química [...] tive uma formação familiar que valorizava profundamente o estudo [...] (Madalena).

[...] no sentido de ter sido sempre muito estimulada à leitura, a ter tido sempre um acompanhamento muito próximo principalmente de meu pai, que foi e tem sido um orientador em meu percurso.[...] Meu professor, como já relatei, era enérgico, bravo mesmo, mas explicava muito bem, eu acho que ele adorava a química, pois passava para nós todos um amor ao que ele ensinava que muitos de nós seguimos carreiras ligadas às ciências, com ênfase em química. (Maria)

[...] eu sempre gostei disso porque eu sempre fui privada de algumas coisas, já que aprendi a ler com jornal de açougue, não tinha livrinho não tinha nada, então eu queria que os outros, algum dia, conseguissem chegar aonde eu cheguei.(Deise).

(A) [...] pessoa que me ajudou na escolha desta profissão foi uma professora de Educação Artística [...] a professora Eliana. [...] Era a professora que cuidava de seus alunos como se fossem seus próprios filhos. [...] Foi aí onde eu conheci os cinco professores que mais me apoiaram na empreitada de prestar um vestibular [...] (João).

Madalena conta como deseja encantar os alunos com o conhecimento científico, da mesma forma que foi encantada pela sua professora de Química. De certa forma, quer repetir as experiências boas da sua vida com os alunos. Assim como é a representante do encanto transmitido pela professora de Química, quer que os alunos também disseminem o encanto que ela lhes proporcionou: este é o modelo que ela tenta seguir e repetir.

Maria fala do pai que foi seu mentor e ajudou-a a tomar decisões em muitos momentos de sua vida; do professor de Química que era muito bravo, mas conseguia passar o amor que tinha pela Química e assim conseguiu deixar muitos herdeiros, desse conhecimento científico.

Deise mostra sua dívida em ter conseguido chegar ao lugar em que está hoje, como professora, devido às dificuldades financeiras que teve em sua infância. Existe o desejo de que os outros também consigam ter acesso ao conhecimento científico, mas sem sofrimento.

João menciona que resolveu ser professor devido à professora Eliana, de Educação Artística, porque tratava seus alunos como se fossem seus filhos. Sabemos, já pela História de Vida de João, que esse aspecto, ser tratado como filho e amado, aparentemente, pesa muitíssimo nas suas considerações. Depois, a convivência com os cinco professores, que mudaram sua perspectiva de vida, proporcionando-lhe uma nova experiência na escola, uma recriação, capaz de lhe dar segurança para encontrar o seu lugar no mundo.

Reunimos, agora, no quarto grupo, situações que mostram a necessidade do professor em obter alguma forma de reconhecimento, o qual ele quer obter dos pais, dos outros professores e da instituição. Ele pode vir na forma de elogios, parcerias, atenção nas aulas ou, até mesmo, na forma de beijos, abraços, fotos, etc.

[...] se você e o aluno se entendem, vocês estabelecem uma relação de simbiose de interesse [...] é o dia que você dá sua aulinha e os caras estão com você, você conversa com eles, eles fazem perguntas, você pergunta para eles, eles tem respostas sejam lá quais 
forem, existe um tipo de interação [...] É o sorriso do cara, é o dia em que eu estou dando uma aulinha e eu estou legal e os caras estão legais comigo e a gente está num ambiente gostoso, sabe? [...] é o abraço dele, é o sorriso dele, é ele querer tirar foto comigo.[...] Tem professor que fala assim...cara burro, né, como ele não entende o que eu estou falando? Eu acho que tem pessoas que são assim, elas tem o conhecimento, mas quando elas vão transmitir têm uma impaciência com a forma como essa pessoa assimila aquilo, ela acha que tem um caminho a ser seguido, então não tem muito jeito para explicar, explica daquele jeito, entendeu? Não entendeu? Então você é burro e não adianta. [...] ele quer completar a renda e aí ele tem essa intolerância que eu falei inicialmente, né, sempre o aluno é bobo, sempre o aluno é incompetente e a culpa não é dele [...] (Madalena).

[...] bons momentos são quando o pessoal pede mais aula né? [...] Cê foi minha professora [...] lembrar e saber que eu dei uma "contribuidinha"... Esse orgulho me faz bem! Isso aí me faz bem pro meu ego. [...] Eu acho que eles gostam de mim (os outros professores). [...] Muito bom momento foi ter alunos que vieram falar pra mim que vão fazer Química, Engenharia Química, Bioquímica... Que... Graças a Deus isso acontece até hoje. Quer dizer, você de certa forma acaba influenciando positivamente esses meninos.[...] Conheço professor que, ah por algum problema sei lá moral ...cantava os meninos, saia com os meninos teve um problema grave num colégio que eu trabalhei, que eu acho que era só para se aproximar deles. [...] Conheço muitos (outros) que a única coisa que eles conseguem fazer é transmitir um recado [...] Não é uma aula. [...] Conheço muita gente que faz bico da nossa profissão. Isso eu acho uma coisa assim muito revoltante [...] às vezes eu acho muito fácil o acesso.(Maria)

Madalena nos conta que é muito importante ela e o aluno fazerem trocas quase simbióticas de aceitação. Quando explica o conteúdo, quer ter certeza que eles estão com ela. Quer o sorriso deles, os abraços, os beijos, ou seja, todos os reconhecimentos possíveis em relação ao seu empenho em procurar as melhores formas de ajudá-los. Conta sobre professores que não deveriam estar na profissão porque taxam o aluno de burro e não mudam nunca a sua performance. Muitos estão apenas buscando uma complementação salarial. Mesmo que esses professores aparentemente não demonstrem culpa, percebemos, pelo seu relato, que se perdem também em justificativas sobre a incapacidade do aluno.

Maria gosta dos momentos em que os alunos pedem mais aula de Química, pois sabe que isso acontece porque soube fazer uma boa administração dos conteúdos e que isso foi capaz de gerar aceitação e sucesso. Sente-se envaidecida quando reconhece que contribuiu para o conhecimento de muitos alunos que estão em ótimos cursos ligados à Química. Considera que está conseguindo uma influência positiva sobre o aluno. Relata também situações em que encontrou professores que utilizaram o espaço da sala de aula para exercer um poder criminoso sobre os adolescentes, e outros que utilizam a profissão como meio de complementar o salário e não se comprometem com nenhum aspecto ético da educação. Isto porque, segundo ela, é uma profissão de fácil acesso. 


\subsection{CONSIDERAÇÕES SOBRE AS ENTREVISTAS}

Os professores falam sobre o conhecimento que acreditam que têm sobre o funcionamento da sua sala de aula, a relação que estabelecem com o aluno e sobre o próprio aluno. $\mathrm{O}$ conhecimento que têm sobre o conteúdo e a capacidade para adequá-lo às diferentes situações de aprendizagem. Sentem-se obrigados a terem um conhecimento muito pessoal dos alunos, pois devem saber em que medida as estratégias de aprendizagem funcionam ou não. Sentem-se responsáveis pela formação pessoal do aluno, pois convivem com ele na época em que sua personalidade está se formando. Tentam cuidar do aluno, pois acreditam que têm conhecimento sobre seus aspectos pessoais, por exemplo, o funcionamento na adolescência. Esse cuidado também pode ser visto na preocupação com a administração de conteúdos para que ele aprenda.

Sabem que não dá para fugir das relações emocionais que permearão as situações diárias na sala de aula. Aparece nos discursos o domínio que os professores acreditam ter sobre o seu próprio estado emocional, a ponto de acharem que conseguem deixar os seus problemas fora de sala. O que fica bem marcado é que acreditam que realmente têm esses conhecimentos e controle sobre os conteúdos, a sala de aula e o aluno. De certa forma, esses conhecimentos lhes dão uma espécie de poder para utilizá-los em benefício da aprendizagem do aluno. Como dar conta de todas as questões que aparecem na sala de aula é impossível, os professores se culpam e se justificam em busca de uma lógica que a atenue.

O poder que os professores estão investidos nas suas práticas pode ser reconhecido no poder que têm de resolver todas as situações da sala de aula, quer sejam de contendas, de atribuição de notas ou na indicação de recuperação de determinados conteúdos. O poder de serem arbitrários às vezes, porque sempre que o aluno não entende, a culpa nunca é deles, professores. Só mais tarde, nas suas considerações internas, podem perceber que não conseguem escapar dessa culpa.

O poder de decisão que os professores têm sobre tudo que se refere aos alunos colocaos na posição de serem justos ou injustos. Sentem-se justos quando tomam decisões sobre a vida deles, seja intercedendo diretamente nas situações, seja facilitando os caminhos deles, ou ainda, tentando entender o contexto em que vivem. O poder sobre os alunos está ligado ao conhecimento que os professores têm pelo seu funcionamento aparente. Também tem relação com o fato de que acreditam serem capazes de ajudar eficazmente os alunos nas suas escolhas. Ao mesmo tempo, têm o poder de colocar tudo a perder quando comprometem, às 
vezes, de maneira irremediável, o gosto que os alunos possam vir a ter pelo conhecimento daquela ciência ou mesmo a sua capacidade de se verem como seres capazes de fazer as tarefas e conseguirem êxito. Os professores têm, ainda, o poder de estabelecer diagnósticos sobre todas as situações vividas pelo aluno na sala de aula, seja sobre comportamentos, aprendizagens ou, até mesmo, questões morais. As reuniões de professores e os conselhos de classe dão validade ao professor desse poder e conhecimento sobre o aluno.

Percebemos que os professores podem utilizar esse poder muitas vezes de uma forma totalmente arbitrária, constrangendo o aluno e classificando-o como incapaz de aprendizagem e, na pior das hipóteses, pode acontecer, até mesmo, a utilização desse poder para exercer um assédio sobre o aluno. Uma preocupação que aparece nos discursos de Maria e de Madalena é a falta de critérios que dá acesso fácil e coloca um mau professor em sala de aula, deixando pessoas que ainda estão em formação à sua mercê.

Os professores se envaidecem quando conseguem criar estratégias que possam promover aprendizagem, nem que, para isso seja necessário fazer um pouco o jogo dos alunos.

A racionalização dos motivos, das razões das escolhas e das atitudes que são tomadas é algo constante na vida dos professores, que têm sempre uma justificativa para as suas atitudes dóceis ou ríspidas, para o seu sucesso ou insucesso na sala de aula. A culpa é o elemento que acompanha sempre os professores. Seja porque foram injustos num castigo, porque exageraram no nível das questões, porque os alunos foram mal nas provas, porque eles não têm tempo de investir na melhoria da suas performances, porque os alunos não gostam deles, porque não mantêm a disciplina, porque os alunos não prestam atenção, porque os alunos não aprendem, e assim por diante. Os professores sentem-se culpados por qualquer coisa que aconteça com os alunos enquanto são os responsáveis. Essa impotência na resolução de algumas situações coloca em cheque o senso de justiça dos professores, que, para serem justos novamente, vão tentar resolver o problema de todas as maneiras possíveis, mesmo que apenas no discurso.

Se considerarmos os elementos que nos chamaram atenção até o momento, podemos dizer que os professores podem acreditar que estão investidos de poder para resolver as situações mais diversas em sala de aula, mas se seus poderes não surtirem efeito, se culparão pelos maus resultados, o que ocasiona uma nova racionalização dos fatos, ou seja, a construção de uma história coerente que fala da impossibilidade de seus sucessos. Verificamos que esse foi um elemento muito reincidente nos discursos, na História de Vida ou nas entrevistas. $\mathrm{O}$ que chama muito a atenção porque a culpa nos parece estar sempre presente 
na relação do professor com o aluno. Se pensarmos que, sempre que nos culpamos, buscamos um jeito consciente ou inconsciente de fazer essa expiação e que, como nunca estamos satisfeitos com os castigos que nos impomos, estaremos presos a esta tentativa perpetuamente.

Os professores também estão falando das dívidas que contraíram com seus pais, seus professores e, até mesmo, com as pessoas que os ajudaram no caminho da profissão. Os modelos utilizados podem ter sido os mais diversos, mas, em relação ao conhecimento científico, seus modelos foram seus próprios professores. Percebemos isso quando eles explicitam essa influência ou em sutilezas que aparecem nos seus relatos como, por exemplo: ser encantado pelos seus professores e agora desejar repetir o encanto como os seus alunos; o seu professor falar o tempo todo e agora ele evitar cometer o mesmo erro com seus alunos; utilizar muitas aulas práticas, porque foi o aspecto que seus professores mais utilizavam e que parece tê-los conquistado para o conhecimento científico.

Querem ser aceitos e reconhecidos pela sua competência, não só pelos pais, instituição e alunos, mas principalmente pelos seus pares. Para obter esse reconhecimento, lançam mão de estratégias em busca de amor, seja facilitando de maneira quase que maternal a administração de conteúdos; seja tirando fotos; seja sendo convidado como paraninfo; seja sendo reconhecidos como competentes pelos seus pares ou pela instituição. A garantia do amor dos alunos pode passar por uma identificação com a disciplina e, até mesmo, com os gostos pessoais do professor.

Percebemos, nessa análise, que, na realidade, esse poder que os professores acreditam ter, dizem respeito à necessidade de cuidar do aluno e de fazer com que a aprendizagem surta efeito. Esse cuidado pode parecer ruim quando os professores dizem se o aluno deve ficar de exame, tirar nota baixa ou até mesmo repetir o ano. Mas, para os professores, o poder de tomar essas decisões nos parece configurar uma maneira de cuidar do aluno e de dar a ele a chance de poder rever situações, mesmo que isso implique em repetência, para se apropriar do conhecimento, ou seja, o sofrimento vai ser bom para o aluno mudar de posição.

Levando em conta que a culpa geralmente surge após o uso de algum tipo de poder pelo professor, podemos fazer algumas inferências no sentido de que, apesar do discurso externado implicar em expiação de algum mal causado ao aluno, esse mesmo discurso pode estar camuflando o fato do próprio professor estar se sentindo, ou se colocando na posição de vilão. E essa posição de vilão, essa posição de poder que o professor administra, também encerra um gozo, e esse gozo pode estar ligado não só à culpa, mas a algum tipo de prazer de causar desconforto ao aluno, simplesmente porque esse desconforto pode lhe causar algum tipo de mal que se converterá em bem, assim que o aluno se deslocar da posição de quem 
resiste. E a culpa aparece, talvez, porque o professor não saiba usar o poder que lhe é conferido na medida certa em que possa auxiliar ao aluno ou, até mesmo, por utilizá-lo muitas vezes sem nenhum critério racional, apenas o poder pelo poder.

\subsection{INTERPRETANDO OS DADOS}

Levando em conta nossa questão de pesquisa e, principalmente, os elementos já interpretados das Histórias de Vida, nas quais encontramos a ocorrência de demandas feitas pelos professores a várias instâncias em busca de garantia para a sua performance, buscamos com as entrevistas obter uma ampliação dessa compreensão. Nas entrevistas encontramos, apesar do diferente contexto de coleta, praticamente uma reafirmação dos elementos já obtidos. Resolvemos, então, tomar essa repetição como uma necessidade inconsciente do professor em deixar marcadas determinadas situações, ou pessoas, na sua história. A necessidade, ou seja, essa insistência em se repetir, de alguma forma, pode estar revelando o que é importante nessa tentativa subjetiva de nos contar sobre a sua entrada e permanência na docência. Portanto, agora mais fortemente do que antes, estamos inclinados a inferir que alguns destes elementos que ressurgiram possam estar garantindo a permanência do professor na profissão.

Começamos interpretando, categorizando e assinalando o primeiro elemento como aquele que diz respeito às influências dos seus próprios professores e pais, como àqueles que, de certa forma, apostaram na sua possível aquisição e sucesso com o conhecimento. $\mathrm{O}$ segundo elemento diz respeito à necessidade de reconhecimento por parte do aluno, por parte dos pais, pela instituição e pelos seus pares, já que o sucesso desses relacionamentos parece aumentar a confiança em lidar com as situações que estão postas pela escola e pela sala de aula. O professor quer ser aceito e reconhecido principalmente pelos seus pares, porque garantem a sua voz nos conselhos de classe, nas considerações sobre o comportamento e aprendizagem do aluno. O amor e o reconhecimento do aluno parecem, muitas vezes, traduzir-se no interesse pela disciplina, ou até mesmo em beijos, abraços, fotos, etc.

O terceiro elemento diz respeito a algum tipo de controle que o professor acredita que precisa ter sobre o comportamento e aprendizagem do aluno porque, aparentemente, necessita de situações ideais de atuação. Buscar a situação ideal na sala de aula parece tapar os olhos para a frustração em relação à indisciplina que é recorrente, então, ele centra seus esforços na 
crença de controle absoluto dos conteúdos, ensino e aprendizagem. O conhecimento, que acredita ter sobre o aluno, se configura numa forma de controle sobre como ele aprende ou deve aprender, deliberando sobre a vida dele, tecendo juízos sobre seu comportamento, fazendo diagnósticos, aprovando ou reprovando, atribuindo notas e ditando as regras de funcionamento da sua sala de aula.

O quarto elemento diz respeito a um desejo, talvez inconsciente, do professor que é o de deixar marcas, as quais podem ser pessoais, quando deseja influenciar o aluno em suas decisões ou profissionais, quando quer que os alunos sejam representantes de sua área de conhecimento no futuro, ou seja, deseja transferir as marcas que ele tem com o conhecimento científico.

O quinto elemento diz respeito à culpa por tudo que não dá certo, fazendo-o racionalizar os sucessos ou insucessos, mostrando qual a razão da impossibilidade de obtenção de êxito. Podemos dizer ainda que ele se culpa porque as questões eram muito difíceis na prova e os alunos foram mal, porque ele não consegue cumprir o planejamento, porque não consegue manter a disciplina, porque não tem tempo de fazer cursos de aprimoramento profissional, etc. Ou seja, desfia longa justificativa por tudo que dá errado na sala de aula. Não está numa situação confortável porque se sente injusto quando dá um castigo, quando perde a paciência, quando não dá atenção, etc. O professor investe na busca de solução para os impasses e, quando o resultado não é o esperado, ou a situação foge de controle, ele racionaliza descrevendo minuciosamente o evento e criando uma história coerente que justifique o fracasso, mas, mesmo assim, sempre se culpa pelo mau resultado.

A tentativa do professor nos parece ser a de encontrar algum tipo de controle sobre essas variáveis de natureza reconhecidamente subjetivas, como as demandas em ser reconhecido e amado; pagar a dívida para com os que acreditaram nele; controlar o ensino e a aprendizagem e os impasses da sala de aula; marcar o aluno na sua vida e em relação ao conhecimento científico e, ainda, se culpar e se justificar encontrando álibis para a sua atuação. $\mathrm{O}$ controle de algumas dessas demandas deveria colocar o professor numa situação de conforto e até de um certo poder, já que ele se acredita capaz de cuidar, entender e suprir as necessidades do aluno na medida certa, sem sofrimento, ou com sofrimento, se ele assim achar necessário. Mas, na realidade, não é o que acontece porque ele é abalado nas suas certezas a cada dúvida do aluno, a cada falta de atenção, a cada nota baixa e a cada falta de comunicação entre ele e o aluno. O que faz com que busque incessantemente álibis para o seu sucesso ou o insucesso. 
Podemos inferir, complementando a análise até aqui empreendida, que um professor se mantém na profissão quando consegue criar uma situação imaginária em que existe a criação de uma espécie de núcleo firme ${ }^{18}$, que utilizamos aqui observando semelhança com a idéia proposta por Lakatos ${ }^{19}$ (1979).

Esse núcleo firme, podemos imaginar que seria formado por grande parte das demandas que o professor se impõe quando está prestando contas a vários outros. Essas demandas foram reincidentes nas duas tomadas de dados que empreendemos e nos ajudaram a inferir que o professor vive procurando situações ideais para atuar e, dentro dessas manobras inconscientes, está sempre buscando imaginariamente criar uma otimização simultânea desses elementos, isto é, criando condições mínimas de sucesso. As demandas que, nesse modelo de compreensão, estariam no núcleo firme seriam a tentativa de resgatar a dívida; desejar ser reconhecido e amado, respeitado e ouvido por todos os envolvidos no ensino; crença num controle e conhecimento sobre o aluno; crença que faz marcas porque deseja fazer do aluno também porta voz do conhecimento científico.

O cinturão protetor ${ }^{20}$, utilizando o modelo de Lakatos, teria a função de manter a integridade dessa situação no núcleo firme. Podemos sugerir que, em torno do núcleo, deveria existir algo que permitisse que os eventos da sala de aula pudessem ter a chance de ocorrer com relativo sucesso e, assim, fazer valer a pena estar na situação de docência. $O$ cinturão protetor teria essa função e diria respeito às justificativas que o professor faz toda vez que algum elemento que está no núcleo firme o coloca em situação de ser questionado, isto é, quer saber sobre a dívida, o reconhecimento, as marcas do conhecimento científico e o controle. Responder a essas questões coloca o professor numa situação de infinitas justificativas e mesmo achando que respondeu satisfatoriamente ao problema, não se convence e, entra numa cadeia de considerações sem fim. O que nos parece é que o fato de fazer justificações, sobre inúmeras situações e eventos que podem comprometer o núcleo firme, coloca o professor em relativa segurança, já que essas justificativas propiciam a criação de condições para que ele não fraqueje diante dos desafios que lhe são colocados, que exista um tempo para a busca de soluções. Na realidade devemos observar que estamos utilizando do modelo de Lakatos, apenas a imagem do núcleo e do cinturão protetor e, a idéia de que o cinturão protege o núcleo.

\footnotetext{
18 núcleo firme - conjunto de hipóteses ou teoria, considerado como irrefutável pelos cientistas (LAKATOS, I. - metodologia dos programas de pesquisa.)

${ }^{19}$ LAKATOS, I. O falseamento e a metodologia dos programas de pesquisa científica. In: LAKATOS, I. e MUSGRAVE, A. (org.) A crítica e o desenvolvimento do conhecimento. São Paulo: Cultrix, 1979.

${ }^{20}$ cinturão protetor - conjunto de hipóteses auxiliares, de modo a adequar o programa aos fatos.
} 
Como pudemos observar na análise com o nosso modelo, esses elementos são subjetivos, ou seja, a natureza desse compromisso é subjetiva e marcada pelas demandas que o professor faz inconscientemente na tentativa da criação, e manutenção, de uma aura protetora que envolva as condições mínimas imaginárias para o sucesso de sua atuação. Esse lugar pôde ganhar uma primeira configuração com nosso modelo de análise.

Reunindo elementos que nos falassem sobre a sustentação da docência, encontramos demandas que nos parecem dizer respeito a aspectos que o professor inconscientemente se preocupa em manter funcionando. Essas demandas são elementos que, acreditamos, fazem parte das condições mínimas imaginárias que o professor precisa para se manter na docência e que estão localizadas em nosso modelo no núcleo firme, porque precisam ser protegidas. As considerações estabelecidas até aqui nos mostraram que, apesar da analogia com o modelo de Lakatos, que nos proporcionou uma certa materialidade para visualizar a situação, um referencial aponta como promissor e que, talvez, possa proporcionar um efetivo avanço nessas interpretações, o psicanalítico.

$\mathrm{Na}$ justificativa pela utilização desse referencial, podemos considerar que até agora temos uma composição de informações entre a História de Vida e as entrevistas que insistem em reaparecer nos discursos e, para obter um aprofundamento, ou seja, entender e captar as argumentações da vida do pesquisado, precisávamos de um referencial que nos desse algum estofo para mergulharmos em algumas questões de natureza estritamente subjetivas.

Bleger (1991) e Mannoni (1981) consideram a entrevista, que é parte do material que nos debruçamos para essa análise, para quem usa o referencial psicanalítico, uma relação intersubjetiva entre dois sujeitos, o entrevistador e o entrevistado, com suas Histórias de Vida e que o inconsciente se faz presente na forma de desejos durante a realização da entrevista. $\mathrm{O}$ que mais nos anima nessa nova interpretação, que usaremos de agora em diante, diz respeito à tentativa de melhor explicitação dos conteúdos latente e manifesto e, assim, fazer novas considerações sobre a manutenção do professor na docência. 


\section{UM NOVO REFERENCIAL DE ANÁLISE}

A análise realizada no capítulo anterior mostrou o impasse em que esta se colocou, no que diz respeito à necessidade de obtenção de mais dados e a utilização de um novo referencial capaz de promover um avanço na sua interpretação. Segundo Villani et al (2006), a exploração de um referencial teórico não é simples porque "requer certa ressonância entre os tipos de dados que podem ser utilizados [...] e os tipos de conceitos que podem amarrar esses dados em um conjunto satisfatório do ponto de vista explicativo". Por esse motivo realizamos entrevistas semi-estruturadas com os pesquisados dos quais já tínhamos obtido as Histórias de Vida, com o objetivo de nos aprofundarmos nesses dados e assim estabelecer o referencial mais promissor para a compreensão da permanência dos sujeitos na docência.

\subsection{O REFERENCIAL PSICANALÍTICO}

Pensando em buscar o que estaria por trás dos discursos dos professores que investigamos, olhamos primeiramente para a própria situação manifesta descrita pelo pesquisado, na sua História de Vida e na entrevista, na tentativa de constituir um caminho para obtenção do que poderia estar latente nos seus discursos.

Utilizar o referencial psicanalítico, nas pesquisas sobre ensino, significa tomar seus conceitos de empréstimo na tentativa de entender a dinâmica da relação simbólica do indivíduo com o conhecimento, portanto a interpretação dos dados assume um lugar de muita importância. Segundo Mendes (2002)

Essa interpretação é uma forma de duvidar do que está posto. É necessário um exercício sistemático da dúvida para entender o significado do fenômeno, os motivos do pesquisador e do pesquisado para emitir esta ou aquela fala, resposta e/ou indícios, sendo a construção de uma rede de significados originada numa variedade de dados, o ponto de partida para entender a dinâmica....(ibid., p. 90).

Finalmente, a interpretação como essência da pesquisa com o referencial psicanalítico, não deve ser submetida a regras, encontra-se a sua maior força na sua especificidade em relação a um conjunto de dados. O dado pode falar e revelar o não desejado, o latente, o inconsciente, sendo na busca deste dito não-dito que o conhecimento pode ser construído, avançando no que ainda não foi revelado pelas pesquisas realizadas até o momento...(ibid., p. 92). 
Embora a Psicanálise não tenha feito parte de nossa formação inicial, temos utilizado vários conceitos do campo psicanalítico em nossa produção acadêmica. $\mathrm{O}$ fato de essa produção vir se mostrando bastante promissora nos permite acreditar em seu potencial de análise e, na sua contribuição para compreender e dar significado aos eventos de sala de aula.

A produção dessa área, com a qual estivemos em contato durante os últimos anos, tem como um dos aspectos principais a tentativa de relacionar o processo de aprendizagem com a linguagem e as condições subjetivas dos atores implicados no processo. Essa necessidade se faz presente devido às dificuldades de se ter acesso às intenções efetivas dos alunos e dos professores, por causa do descompasso entre as falas dos envolvidos na sala de aula e seus desejos implícitos ou até inconscientes. Esta dificuldade sugeriu o deslocamento para referenciais que pudessem de alguma forma ajudar a contorná-la, como por exemplo, a Psicanálise (VILLANI; CABRAL, 1997). Nesse sentido, e ainda investigando o funcionamento de grupos nas salas de aulas, temos os trabalhos de Villani e Barolli (2000), Villani (1999), Villani et al (2000), Barros et al (2005), Barolli (1998), Barolli e Villani (1998), Arruda (2001) e outros.

Iniciamos, então, a apresentação da constituição do sujeito e dos três registros Lacanianos. Depois, explicitamos mais detalhadamente os elementos sobre os quais orientamos a nossa tentativa de interpretação, pois, a opção que fizemos na análise foi de utilizar apenas as idéias e conceitos da Psicanálise com as quais tínhamos alguma familiaridade.

\subsubsection{A Constituição do Sujeito}

Para entender a constituição do sujeito, em Psicanálise, buscamos as enunciações de Lacan (1998), em que formula que, na pré-história do sujeito, existe um lugar que foi destinado ao futuro bebê pelos pais e que se manifesta na escolha do nome, nas fantasias dos pais e, principalmente, no discurso que se cria em torno do bebê. Esta é a cadeia significante ${ }^{21}$ familiar que, mesmo o bebê ainda não estando presente, estará em ação construindo tudo o

\footnotetext{
${ }^{21}$ Significante - conceito retirado da lingüística, de Saussure, nos diz que o signo lingüístico é composto por duas partes: o significante (S) e o significado (s). A palavra "árvore", por exemplo, é um signo por ter um significado - o conceito - e um significante - a "imagem acústica" árvore. SAUSSURE, F - Curso de Lingüística General. Buenos Aires, Ed. Losada, 1970. Lacan na leitura de Freud, recolhe a idéia de significante e significado no "funcionamento mental".O que difere radicalmente - o uso dos dois conceitos em Lacan é que este nos diz da primazia do significante sobre o significado - $S / s$. MILLER, Jacques-Alain. Percurso de Lacan - uma introdução. 3.ed. Trad. Ari Roitman. Rio de Janeiro: Jorge Zahar Editor, 1987.
} 
que se dirá sobre a criança que está por vir ao mundo. Quando o bebê nasce não significa que também nasceu o sujeito porque, logo após o nascimento, o bebê ainda é um corpo, coisa, o real de uma constituição orgânica que age por reflexos arcaicos e automatismos fisiológicos.

Segundo Rodulfo (1990):

A questão do que é uma criança, em que consiste uma criança, conduz à préhistória, tomando-a não apenas no sentido que lhe outorga Freud (primeiros anos de vida, que logo sucumbem à amnésia), mas à pré-história em direção às gerações anteriores (pais, avós, etc.), a história dessa família, seu folclore. [...] A história da criança deixa de ser um inventário de tudo o que pode fantasiar ou não, o que conduz, por si só, a toda a problemática da préhistória, isto é, o que o precede, os modos e declives do ocorrido, determinantes para essa criança, antes que propriamente exista (RODULFO, 1990, p. 17).

A história de uma criança começa, então, muito antes do seu nascimento e tem relação com o lugar que ocupa no imaginário dos pais. Para a Psicanálise, as fases de desenvolvimento que a criança atravessa, e que começam com o seu nascimento, são de outra natureza, diferente da estabelecida pela Psicologia, pois, em determinado momento, haverá uma ruptura na relação diádica do bebê com a mãe, que será intermediada pelo pai e que se tornará a questão central do complexo de Édipo. Lacan, segundo Bleichmar (1992), nos diz que o que importa, nessas primeiras fases da vida da criança, não são realmente os pais da criança, mas as funções materna ou paterna, que eles, ou quem os substitua, desempenhem. Lacan (2002) propõe que a família deve ser compreendida pelas relações sociais que estabelece, porque desempenha um papel fundamental na transmissão cultural e no processo do desenvolvimento psíquico do sujeito.

O estádio do espelho postulado por Lacan (1998), nos diz que a criança, no início de sua vida, experimenta o seu corpo como esfacelado, sem unidade e a identificação primordial com a imagem do espelho é uma antecipação da conquista corporal que a criança deverá fazer. O estádio do espelho se organiza em três tempos:

No primeiro tempo, o bebê com um ego ainda fragmentado a partir da indicação da mãe, vê a sua imagem unificada em um espelho e esta imagem passará a servir de referência organizadora da integração desse ego. Segundo Nasio (1995), a conquista de uma imagem corporal demora, já que a criança inicialmente confunde a si e o outro, e é nesse outro que ela se orienta para criar a imagem do seu próprio corpo. O que está acontecendo é um assujeitamento ao registro do imaginário e a imagem apreendida é tida pela criança como a de um outro real - esse outro se escreve com a letra 'o' minúsculo e diz respeito a identifícação narcísica com a imagem do semelhante, do pequeno outro. No segundo tempo, aos poucos, começa fazer uma discriminação da imagem e a perceber que o outro no espelho não é um outro real, mas 
uma imagem, até que, finalmente, no terceiro tempo, a criança, além de conseguir diferenciar a imagem, reconhece que aquela é a imagem do seu próprio corpo, que aquela é a sua imagem, o que permite que ela se reconheça e recupere a dispersão do corpo esfacelado. E é a partir desse primeiro jogo de identificação, que o sujeito tem uma referência imaginária do seu próprio corpo e que vai ser capaz de orientá-lo em relação às identificações futuras. Vivenciar o estádio do espelho não é suficiente para a criança tomar posse do seu corpo, que só vai se constituir como tal quando for capaz de simbolizar, ou seja, quando passar pelo complexo de Édipo.

O complexo de Édipo se organiza também em três tempos: o estágio do espelho; a identificação do bebê com o desejo da mãe; a identificação simbólica com a lei do pai.

No primeiro tempo, o olhar da mãe exerce a mesma função de espelho já que reconhece a criança e permite que a criança se reconheça como distinta dela: é a função materna. A criança, nessa fase, é mais assujeitada do que sujeito e, para agradar a mãe e ser tudo que ela deseja, quer se colocar no lugar do falo ${ }^{22}$. Ela está alienada no desejo da mãe e a relação se dá pela identificação fálica da criança como objeto de desejo da mãe. Ela se encontra confundida com o desejo da mãe e, fundida com ela, sente-se como um prolongamento da própria mãe, o que a coloca no registro do imaginário.

O segundo tempo introduz o elemento simbólico no psiquismo através da interdição edípica $^{23}$, ou seja, a simbolização da lei. Nesse momento surge a intervenção do pai que vai privar a mãe do seu objeto fálico e o filho do seu objeto do desejo. Através da inclusão efetiva da figura paterna no cenário, a criança é inserida no registro da castração e são interditados seus impulsos. O pai interdita a mãe, pois sua mediação intervém sob a forma de privação. Ele aparece como um terceiro na relação mãe-criança e apresenta-se como objeto do desejo da mãe, imaginariamente, como aquele que é o falo. A função paterna no complexo de Édipo fará a substituição de um significante por outro significante. Então, o significante originário do desejo da mãe será recalcado e, como conseqüência, o significante nome-do-pai pode ser introduzido, dando acesso à ordem simbólica. Portanto, o significante nome-do-pai é produto de uma metáfora porque, como significante, substitui outro significante, o desejo da mãe, e esse recalcamento faz com que o desejo persista e insista em se representar. A linguagem, como mediadora, poderá se impor ao desejo, que precisa ser traduzido em palavras e, desse modo, se traduzirá numa demanda, o que fará com que o desejo permaneça sempre insatisfeito. $\mathrm{O}$ fato de aceitar a interdição faz com que a criança finalmente se inclua no espaço das regras sociais: é a função paterna. A

\footnotetext{
22 Falo - em Psicanálise, o uso desse termo sublinha a função simbólica desempenhada pelo pênis na dialética intra e intersubjetiva, enquanto o termo pênis é, sobretudo, reservado para designar o órgão na sua realidade anatômica. LAPLANCHE, J. et PONTALIS, J. B. Vocabulário da Psicanálise. 4ed. São Paulo: Livraria Martins Fontes Editora ltda, 2004. p.166.

${ }^{23} \mathrm{Na}$ interdição edípica, a criança é levada a abdicar de sua fixação na relação diádica com um dos progenitores.
} 
metáfora paterna dá acesso ao sujeito, ao simbólico, estrutura o sujeito e lhe coloca na situação de desejante. Essa situação também faz com que haja a alienação do desejo na estrutura da linguagem, o que nos torna sujeitos alienados na demanda. O Outro ${ }^{24}$, quando estabelece as leis da linguagem que nos estruturam e das relações de parentesco que vivemos, também dita as regras a que se subordinarão nossos desejos e, conseqüentemente, nossas demandas.

No terceiro tempo há um declínio do complexo de Édipo. Começa a findar a rivalidade fálica com o pai. $\mathrm{O}$ aspecto marcante dessa fase é a simbolização da lei. $\mathrm{O}$ menino renuncia a ser falo e se empenha no sentido de vir a possuí-lo.Isto acontece porque a instância paterna deixa seu lugar no imaginário para o lugar de Pai simbólico, no qual será investido como aquele que tem o falo. A dialética do ser e ter põe em jogo as identificações e o menino passa a identificar-se com o pai que, supostamente, tem o falo. Como conseqüência, a criança se torna sujeito, não apenas da linguagem, mas do desejo, já que não é mais apenas objeto do desejo da mãe ou do pai. Aparece, então, a possibilidade da criança vivenciar a si mesma como completa e como objeto do desejo do outro, ela identifica a si mesma como um, ou seja, ela é colocada na ordem simbólica.

$\mathrm{Na}$ constituição do sujeito, a relação com o Outro, mãe é permeada pelos conceitos de necessidade, demanda e desejo ${ }^{25}$. As necessidades são imperativas e essenciais para a vida como a alimentação, o ar, o calor, a água, não podem ser substituídas. Quem atende essas necessidades é sempre alguém que cuida do bebê, habitualmente a mãe, e que logo significa os gritos do bebê. A mãe os reconhece como constituindo uma demanda, mas ela os interpreta no nível do desejo da criança em tê-la próxima, de que ela lhe dê algo, ou qualquer outra coisa. E é pelo modo como a criança responde que o Outro vai dar a dimensão do desejo para o grito de necessidade, e este desejo, com que a criança foi investida, é inicialmente resultado de uma interpretação subjetiva dada pela mãe, de sua própria fantasia. A criança procura ser o objeto que satisfaz o desejo da mãe e isso acontece de tal maneira que podemos falar de uma identificação do desejo da criança com o desejo da mãe. Esta identificação, necessariamente, tem lugar no nível do inconsciente, como parte do processo pelo qual o inconsciente é

\footnotetext{
${ }^{24}$ Outro (Grande Outro) - Para Lacan a linguagem e a fala, através do social, tecem o Outro de cada cultura, o chamado Outro social ou Outro simbólico. O outro dos sujeitos é um produto da incorporação da cadeia de significantes familiar do sujeito....Do ponto de vista estrutural, o Outro não é fixo, transformando-se continuamente.Ele sofre influências tanto da sociedade quanto da estrutura familiar do sujeito. Daí, Lacan revelar que o Outro não é senão um semblante, um parceiro com o qual o sujeito interage. Um Outro que vai sendo internalizado pelo sujeito até se tornar o seu parceiro mais íntimo. .( MRECH, L. M. Psicanálise e educação: novos operadores de leitura. São Paulo: Pioneira, 1999.p. 129-140)

${ }^{25}$ Desejo - Para Lacan, o desejo é altamente transformador e questionador. No início, o sujeito se constitui de uma forma alienada através da assumpção do desejo do Outro. No entanto, aos poucos o sujeito precisa se descolar deste processo, o que é plenamente alcançado através da análise clínica, quando o sujeito passa a ir em busca do seu desejo.O desejo não remete a posições confortáveis, fáceis de serem vividas, mas àquilo que leva o sujeito a se implicar na vida.Quando o sujeito se torna desejante entra em um processo de grande mobilidade libidinal. ( MRECH, L. M. Psicanálise e educação: novos operadores de leitura. São Paulo: Pioneira, 1999.p. 129-140)
} 
estruturado e só pode ser quebrada pela intervenção de um terceiro que, para Lacan (2005), é a presença, na vida da mãe, de elementos sócio culturais que delimitam o papel da criança em sua vida e pela presença do pai simbólico, que lança os limites para a totalização do desejo, já que nomeia a criança como ocupante de um lugar particular no sistema de parentesco.

\subsubsection{Os Três Registros Psicanalíticos: o imaginário, o real e o simbólico.}

Lacan (2005), teorizando a função paterna, nos fala do Nome-do-Pai que é o significante que está em jogo no complexo de Édipo e que faz laço entre os registros psíquicos para que se estabeleça uma ligação entre eles. Ele amarra os três registros utilizando a topologia dos nós borromeanos, que é a estrutura pela qual as leis do inconsciente determinam o sujeito.

O imaginário é o registro psíquico que corresponde ao ego, ao eu do sujeito, cujo investimento libidinal foi denominado por Freud como Narcisismo. Lacan (1998) nos diz que o imaginário é a fonte de alienação do sujeito, ou seja, ele age no sentido de ficarmos presos na imagem do espelho e não na escuta do sujeito ou do objeto.

No seu texto sobre o estádio do espelho, Lacan (1998) tratou exatamente dessa constituição da função do eu, em que utilizou um esquema ótico que fosse capaz de introduzir, além da constituição do eu, também a função do sujeito na relação especular. Este é o estágio em que o bebê se mostra muito interessado em sua imagem no espelho, ele se reconhece e se identifica com ela e, segundo Lacan (1998), esta alienação é imaginária porque ocorre uma identificação com a imagem do outro. "É um desenvolvimento no qual o imaginário está inscrito, e não um puro e simples desenvolvimento fisiológico". (MILLER, 1987, p. 16).

Estamos sempre desejando uma completude que não pode jamais ser alcançada, porque qualquer identificação é sempre imaginária. Identificar é dissolver as fronteiras entre o sujeito e o objeto da identificação. Segundo Ogilvie (1991):

O espelho, isto é, este momento da primeira relação consigo mesmo que é irremediavelmente, e para sempre, uma relação com o Outro, só representa uma fase privilegiada na medida em que tem um valor exemplar para toda a seqüência de um desenvolvimento; não é um estádio destinado a ser superado, mas uma configuração insuperável. 'Estágio do espelho, bem mal nomeado, onde afinal se trata muito pouco de espelho e de estágio'. (ibid., p.112). 
A experiência do espelho faz com que a criança perceba o seu corpo como uma unidade porque a experiência que tem sobre seu próprio corpo é de despedaçamento, de uma falta total de coordenação. Por isso, apesar do estranhamento, o bebê já é capaz de reconhecer como sua aquela imagem. O imaginário é a categoria psicanalítica da demanda de amor, da completude com o Outro materno. A demanda de amor depende da linguagem, ela está alienada na linguagem, não há possibilidade de existir demanda sem linguagem e ela se expressa através da cadeia de significantes.

O registro do simbólico é o lugar do código fundamental da linguagem. Ele é a lei, estrutura regulada sem a qual não haveria cultura, a quem Lacan chama de grande Outro. $\mathrm{O}$ Outro, escrito em maiúscula, foi adotado para mostrar que a relação entre o sujeito e o grande Outro é diferente da relação com o outro recíproco e simétrico ao eu imaginário. O simbólico é o registro do desejo, da articulação significante em forma de saber.

Miller (1987), no trecho a seguir, consegue nos fornecer uma apresentação bastante clara do simbólico.

O outro é o grande Outro da linguagem, que está sempre já aí. É o outro do discurso universal, de tudo o que foi dito, na medida em que é pensável. [...] É também o Outro da verdade, esse Outro que é um terceiro em relação a todo diálogo, porque no diálogo de um com outro sempre está o que funciona como referência tanto do acordo quanto do desacordo, o Outro do pacto quanto o Outro da controvérsia. Todo mundo sabe que se deve estar de acordo para poder realizar uma controvérsia, e isso é o que faz com que os diálogos sejam tão difíceis. Deve-se estar de acordo em alguns pontos fundamentais para poder-se escutar mutuamente. ... É o Outro da palavra que é o alocutário fundamental, a direção do discurso mais além daquele a quem se dirige. A quem falo agora? Falo aos que estão aqui e falo também à coerência que tento manter. (ibid., p. 22)

$\mathrm{O}$ real $^{26}$ é o registro psíquico que não deve ser confundido com a noção comum de realidade. Para Lacan (1998) o real é da ordem do impossível, é aquilo que não pode ser simbolizado e que permanece impenetrável ao sujeito do desejo. Real é o que falta na ordem simbólica, são os restos do imaginário que não podem ser eliminados em toda articulação do significante, é aquilo que só pode ser aproximado, jamais capturado.

\footnotetext{
${ }^{26}$ Real-.O registro do real para Lacan se distingue da chamada realidade concreta. O real não é apreendido diretamente. O registro do real, apreendido através dos semblantes, não pode ser confundido com a predominância do que ocorre na nossa cultura através dos simulacros. Estes são apenas cópias, produtos materiais, produtos culturais, surgidos através da intensificação da produção da sociedade de massa, em função do aumento na distribuição e no consumo. Para nos acercamos do registro do real, é preciso que nós nos direcionemos para o real do inconsciente. Algo que não pode ser acessado diretamente através de simulacros, mas dos semblantes. Os semblantes são construções, elaborações que possibilitam o sujeito se localizar de alguma forma frente à realidade.(MRECH, L. M. Psicanálise e educação: novos operadores de leitura. São Paulo: Pioneira, 1999.p. 129-140)
} 
Lacan (1998) nos diz que não existe uma adequação na relação entre o objeto e sua imagem, entre as partes do corpo e a imagem que se tem dele. O registro do real é aquilo que vez por outra encontramos horrorizados, como sendo aquilo que não tem nome e que surge como, por exemplo, a catástrofe repentina ou a morte. $\mathrm{O}$ real é aquilo que resta quando as imagens e os símbolos recortam os objetos da experiência como algo que não pode ser simbolizado ou imaginado. O real é a categoria da pulsão, da morte e da putrefação.

As três categorias estão sempre onipresentes, pois o real e o simbólico devem também aparecer no registro do imaginário, o real e o imaginário aparecem no registro do simbólico e o imaginário e simbólico devem estar presentes no registro do real. Pois, como no nó borromeano, ao desatar um dos cordões, os demais ficam soltos, portanto, existe uma solidariedade constitutiva entre todos os registros.

\subsubsection{Os elementos Psicanalíticos utilizados}

Nesse momento retomamos os conceitos já desenvolvidos sobre o processo da Constituição do Sujeito, aliado aos conceitos de imaginário, simbólico e real com os quais ampliamos a nossa compreensão teórica, com o objetivo de explicitar melhor os quatro elementos que utilizamos na nossa análise, que são: demanda de amor, reedição da situação parental, gozo e dívida simbólica. 


\subsubsection{Demanda de amor}

Em sua obra A Dinâmica da Transferência, Freud (1996) determina que a característica da transferência é a superposição do passado ao presente e apresenta dois componentes em sua construção amorosa: uma consciente, porque uma parte da libido está disponível à consciência e, outra, inconsciente, vítima de recalcamento e que vai provocar o fenômeno da transferência. Para Lacan (1961), a transferência acontece quando, durante o processo de análise ${ }^{27}$, surge uma situação imaginária, que teve sua origem no que ele conceitua como fase do espelho. Nessa fase a criança, buscando manter o amor da mãe, identifica-se com o desejo dela, o qual, pela teoria freudiana, vem a ser o desejo do pênis. A criança, para manter essa relação estável com a mãe, imagina-se como o pênis que a mãe quer ter. Ao se imaginar como desejo da mãe, a criança passa a vivenciar o desejo do desejo, uma relação que Lacan (1999) chama de imaginária e, na qual, tanto objeto como sujeito são, basicamente, iguais e diz que o desejo do próprio Outro é o que se visa na demanda, portanto, toda demanda é uma demanda de amor.

Na demanda de amor o desejo vem do Outro, no caso, a mãe que espera que o filho seja o falo, ou seja, a mãe o deseja (o falo) no filho. E é nessa relação com o Outro que o próprio sujeito se constitui. Esse Outro, como lugar da linguagem, é o lugar pelo qual deve passar necessariamente a demanda do sujeito e o que ele demanda, através da linguagem, está muito além dela, mas que só pode ser vislumbrado através dela. Lacan (1999) nos diz que:

[...] Daí o caráter problemático e ambíguo do lugar onde se situa o desejo. Esse lugar está sempre para além da demanda, considerando que a demanda almeja a satisfação da necessidade, e no aquém da demanda, na medida em que esta, por ser articulada em termos simbólicos, vai além de todas as satisfações para as quais apela, é demanda de amor que visa ao ser do Outro, que almeja obter do Outro uma presentificação essencial - que o Outro dê o que está além de qualquer satisfação possível, seu próprio ser, que é justamente o que é visado no amor. (LACAN, 1999, p. 418).

A demanda de amor referencia, em nossa análise, a demanda por reconhecimento. Portanto, seguindo o nosso modelo empírico, a demanda de amor está colocada no núcleo firme. Exemplificamos essa demanda no discurso de nossos pesquisados e, a seguir, vamos verificar em que medida essa demanda foi solicitada por cada um.

\footnotetext{
${ }^{27}$ Processo de análise - em psicanálise a matéria é o "desejo do analisando e que é idêntica ao desejo do operador" (p. 8).Os meios técnicos nascem no interior do processo analítico, no interior da sessão. O estado particular em que deve permanecer o psicanalista é um estado de expectativa, "de uma expectativa escolhida, de uma disposição orientada, polarizada na realização de uma experiência singular" (p. 9). Nasio conceitua quatro diferentes fases do tratamento: retificação subjetiva, sugestão, neurose de transferência e interpretação. NASIO, J.D. Como trabalha um psicanalista? Rio de Janeiro: Jorge Zahar Editor, 1999, $170 \mathrm{p}$.
} 


\subsection{Madalena}

Madalena mostra sua demanda de amor, quando nos conta que apesar de seus alunos terem muitos problemas de relacionamento porque estão na fase da adolescência, e ao mesmo tempo nos diz que 'se você e o aluno se entendem, vocês estabelecem uma relação de simbiose, de interesse' a relação está funcionando. Fala ainda sobre outras situações em que esse tipo de interação ocorre, ou seja, situações em que ela, como se fosse uma mãe, mantém o aluno preso na relação que está se desenvolvendo. Espera que o aluno a reconheça e retribua a dedicação com que ela atua; é então que ela consegue obter a retribuição do amor que ela coloca na relação da sala de aula.

[...] é o dia que você dá sua aulinha e os caras estão com você, você conversa com eles, eles fazem perguntas, você pergunta para eles, eles tem respostas sejam lá quais forem, existe um tipo de interação,... mas quando você fala alguma coisa e o cara fala- puxa legal isso, é muito gostoso a gente ouvir isso, puxa eu nunca tinha pensado nisso, nossa vou usar isso na sala de aula, vou usar isso em casa. Isto é se sentir útil né!

[...] eu comecei a dar aulas e comecei a ter relacionamento com alunos que tem todos problemas de relacionamento humano, mas você esta lidando com pessoas é... e se você e o aluno se entendem, vocês estabelecem uma relação de simbiose, de interesse

[...] É o sorriso do cara, é o dia em que eu estou dando uma aulinha e eu estou legal e os caras estão legais comigo e a gente está num ambiente gostoso [...] o que me mantém é essa relação humana é esse aluno que de alguma forma me devolve muita coisa, é o abraço dele, é o sorriso dele, é ele querer tirar foto comigo.

No fragmento abaixo vemos Madalena fazendo um discurso em que, praticamente, mostra a função, quase materna, que ela desempenha, ao cuidar do aluno mostrando-lhe os melhores caminhos e opções para caminhar pelas próprias pernas. “[...] você está fazendo um trabalho, você não veio ao mundo exclusivamente pra ganhar seu dinheirinho, às vezes eu falo isso pros meus alunos eu não estou aqui pra ganhar um dinheirinho, eu estou aqui pra vocês atingirem os objetivos de vocês [...]”.

Outro fator que aparece muito no discurso dela é a necessidade de que, além desses reconhecimentos, haja contato físico. Nos parece que para ela o contato físico representa a possibilidade de fortalecimento da relação afetiva, ou seja, é criada uma cumplicidade e uma certeza de amor irrestrito. "Na sala de aula eu adoro... eu não sei te explicar... se uma aluna tem uma dúvida eu vou lá, se ela tem cabelo comprido, as meninas normalmente tem, então eu vou explicando e mexendo no cabelo dela assim,... parece que são todos minhas crianças..." Quer ser reconhecida pelos professores do cursinho onde trabalha e, como não consegue por ser mulher atuando na área de exatas, esse reconhecimento é feito, então, através dos alunos, que validam a sua presença com uma aceitação coletiva, ou seja, 
conseguem mantê-la na instituição por uma aceitação explícita, o Ibope. Com esses

professores a relação se encontra comprometida, mas ela não desiste, porque ser aceita por bem ou por mal, também pode ser considerado como uma forma de reconhecimento e possível amor.

Eu peguei um cursinho para dar aulas, que é um meio profundamente preconceituoso com a mulher principalmente da área de exatas, então você tem sempre que estar mostrando capacidade entendeu? Meu ibope, que lá tem essa coisa de ibope, sempre foi alto e sempre se achou uma desculpa para o meu ibope ser alto, é porque eu tinha um bom relacionamento com o dono ou porque eu usava saia e os alunos gostavam de ver minha perna, eu ouvi muito dessas coisas assim [...].

Madalena quer marcar o aluno para o conhecimento, mostrando a possibilidade da química ser utilizada de forma ética por eles, pensando num mundo melhor. Vislumbra a retribuição desse amor no dia em que os seus alunos se tornarem mais éticos e generosos, talvez influenciados pelo amor que ela lhes dedica. Durante a justificativa, ela narcísicamente fala sobre a sua competência e como acredita na sua capacidade, mas quer ser melhor ainda, para conseguir atingir mais os alunos, ou talvez para garantir cada vez mais esse reconhecimento.

[...] eu tenho que acreditar que tem jeito, então eu me agarro a isto, a questão do conhecimento que produza um mundo melhor [...] e vejo se eu consigo gerar algum pouco de respeito e conhecimento. [...] Ah...eu só gostaria de atingir mais...eu não acho que eu estou no caminho errado não, eu gosto do que eu tenho construído, entendeu? Só que eu acho que sempre tem um jeitinho melhor, entendeu? [...] essa causa ambiental, eu acho que ela faz com que a química passe a ter um interesse maior sabe? Então talvez eu...eu esteja estudando tanto para me aprofundar e também para estar produzindo e distribuindo esse conhecimento [...] e se essa química atingir esses caras de tal forma que eles se tornem mais éticos, mais cidadãos, mais responsáveis, mais generosos. É esse professor que eu gostaria de ser, eu diria é aí mesmo que eu quero chegar. Eu não sou uma má professora, entendeu? [...] Não só misturar ácido com base que vai dar sal e água, mas... porque misturar acido com base e o que eu vou fazer com esse sal e água? Que utilidade isso vai ter pro mundo? Pra vida dessas pessoas? Quanto mais eu colaborar para uma vida melhor mais eu vou me sentir uma boa professora, entendeu?

\subsection{Maria}

Maria nos fala da sua demanda de amor nos contando sobre a sua contribuição para a formação dos seus alunos adolescentes, situação em que ela pode ter acesso ao emocional e, portanto, ao amor e ao ódio desses alunos.

[...] (o professor) trabalha intimamente com pessoas que no meu caso tão em formação, eu acho que forma muito caráter nesta época, muito de personalidade, então eu acho que é muito importante ter esta noção, não sei se eu to dando demais importância, mas é como eu sinto (retomada de fôlego). E... então é alguma coisa meio que privilegiada. Além de mexer com o conhecimento, que é o saber, a bagagem mesmo cognitiva desta pessoa tem 
o emocional, que é muito envolvido, porque o adolescente ele, ele é tudo...Tudo é sentimento ele odeia, ele ama com muito ardor [...].

Ela mostra aqui o poder que tem de conduzir o aluno, quase que hipnoticamente, nas suas explicações sobre o conteúdo fazendo com que ainda ocorra na aula uma interação satisfatória. Acredita que influencia os alunos, porque muitos deles seguem carreiras ligadas à Química, sendo capaz de fazer com que haja uma identificação do desejo do aluno com o seu, pois ele a atende e vai estudar Química. Acredita estar marcando o aluno, transferindo as boas marcas que existiram na sua vida, mesmo que seja através do conteúdo.

[...] é toda vez que eu consigo alcançar os meus alunos. [...] E aí quando eu consigo mostrar pra eles, ou ir desenvolvendo algum assunto com eles e que eles vão se interessando, ou porque a gente contextualiza, ou porque eles vão perguntando e vão aprendendo, esses momentos foram muito bons. (Retomada de fôlego). Muito bom momento foi ter alunos que vieram falar pra mim que vão fazer Química, Engenharia Química, Bioquímica... Que... graças a Deus, isso acontece até hoje. Quer dizer, você de certa forma acaba influenciando positivamente esses meninos. [...] bons momentos são quando o pessoal pede mais aula né? Esse ano aconteceu muito, falar "Ah! Muito pouca aula. Eu quero mais! É muito bom! Muito gostoso! Com essa introdução que eu to dando a Física e Química.

Maria quer também o amor dos outros professores e da instituição. Na situação descrita, quer trabalhar junto com os professores para ser reconhecida, talvez mostrar a sua competência e conseguir ainda o reconhecimento da instituição, que, nessas condições, não vai lhe fechar as portas.

Eu acho que eles gostam de mim (os outros professores). Parece... porque eu tenho um relacionamento social muito bom. Eu crio amigos nos lugares que eu vou. [...] Na escola que eu to que é nova, né? Algumas pessoas vieram (me procurar) pra gente trabalhar assuntos [...] interdisciplinarmente. [...] eu achei que foi muito legal. Eu não era nada conhecida. Então eu sinto que pelo menos parece que não tem nenhuma porta assim me fechando.

Deseja fazer marcas no aluno em relação ao conhecimento, mas quer que elas sejam percebidas, para que lhe angarie um reconhecimento eterno. Esse amor é quase narcísico já que, segundo ela, lhe alimenta o ego.

[...] muitas vezes é a questão minha de idealismo, me orgulho de... Acho que é uma coisa bem besta que todo mundo deve achar. Vou te falar [...] Quando eu encontro um menino ou uma menina que fala assim: "Cê foi minha professora, quanto tempo". Lembrar e saber que eu dei uma contribuidinha... Esse orgulho me faz bem! Isso aí faz bem pro meu ego. 


\subsection{Deise}

Deise fala das dificuldades que enfrentou no seu primeiro dia de aula, mas que foi capaz de gerar um saber quase intuitivo sobre a relação e, que deu certo, conseguindo reconhecimento. Podemos dizer que essa situação é praticamente uma retribuição amorosa na medida em que, apesar de existirem outras opções, os alunos não foram embora, mas preferiam ficar e assistir as aulas.

[...] uma turma pesada de escola pública noturno, muitos viciados fedendo maconha e eu muito novinha, então tiravam sarro dizendo...escuta senta pra ter aula a professora já vai chegar...aí eu consegui meio que entrar na deles falando um pouco de música, de rock, coisa que eu nem curto, mas eu falei a gente ta aqui pra estudar [...] a gente vai ficar até a hora de acabar e aí eles falavam, vamos então professora e aí ficavam pra aprender, não pra brincar e isso foi muito legal.

\subsection{João}

João, talvez pela história da sua vida familiar, dá muito valor ao fato de ser amado. No seu relato percebemos o amor dedicado por seus professores, e que implicitamente aparece, em forma de bons prognósticos sobre os eu futuro. Como exemplo, temos as professoras primárias que diziam que ele teria um lugar no mundo. A escola, em que fez o curso duas vezes, podemos considerar como o lugar em que, na segunda vez, encontrou todo o amor e reconhecimento que procurava receber dos professores, que o tratavam como igual. Hoje, que já é professor, faz perceber, no seu discurso, sua definição de amor, que é o de ser motor de mudanças, fazendo com que as pessoas confiem em buscar seus objetivos. Fala da falta de amor que vê e viu em alguns professores e não quer que o seu amor pelo trabalho acabe. Percebemos no seu discurso como o amor que buscou, e encontrou na escola, marcou-o, pois acredita que esse amor disponível para a profissão e pela escola é dever do professor.

Indo contra as nossas considerações acima, João declara que não teve amor de seus professores, o que é contraditório porque os seus vínculos mais importantes foram criados na escola e, entretanto, o amor de que ele foi alvo parece não ser reconhecido. Nos parece que ele se coloca na profissão em continuação a essa busca, ao mesmo tempo em que quer evitar o sofrimento da falta de amor aos seus alunos. Provavelmente, embora não reconheça, a escola se coloca no lugar da família, pois é lá que encontra a promessa de um lugar no mundo. Resolveu refazer o ensino profissionalizante porque talvez precisasse re-atualizar essas 
promessas, pois percebeu que seu lugar no mundo não estava ainda disponível. Foi nessa repetição que conseguiu ganhar confiança para voltar a buscar esse lugar. Apesar de fazer críticas aos professores que não tem amor pelos seus alunos, e que esse amor também lhe fez falta, percebemos que ele teve acesso e foi incluído pelo amor de seus professores. Entretanto, ele não parece reconhecer que isso tenha acontecido e, muito provavelmente, nunca venha admitir essa inclusão amorosa feita por vários professores em vários momentos de sua vida e que foi o elemento capaz de lançá-lo em busca da promessa de um lugar no mundo.

[...] A entrada no programa de pós-graduação da universidade tem muito a ver com este amor, mas também tem a ver com a falta de amor que tenho observado em alguns professores. O amor faz as pessoas acreditarem em um objetivo e lutarem por ele com mais garra. Eu faço Mestrado em ensino de Física porque acredito que posso dar a minha contribuição, pelo menos, onde trabalho. Por isso, faço o impossível para que o meu amor pelo trabalho que eu faço não se acabe.

Ressente-se da sua mãe e dos professores do ensino básico que lhe negaram amor, mas lhe deram palmadas e castigos.

[...] Até hoje eu tento ser o professor que eu nunca tive nos anos básicos da escola, até completar o ensino médio.[...] lembro de ter levado duas pancadas de palmatórias na mão: uma por causa da Matemática e outra por causa de um beijo que eu dei em uma menina [...]. Apanhei de novo da minha avó, pelo mesmo motivo.[...] Na nova escola, conheci outra professora carrasca [...]. Ela com a minha mãe faziam um par perfeito: eu apanhava da professora na escola e da minha mãe em casa.

Dá o amor necessário para que os alunos acreditem que são capazes de procurar também, um lugar no mundo. “[...] Hoje sou um professor de Física que acredita nos meus alunos e não deixo que nenhum deles caia na besteira de não acreditar que são capazes de fazer um curso [...] em qualquer faculdade pública”.

A demanda de amor de João também passa pelo reconhecimento dos seus pares. A história que nos conta diz respeito ao preconceito que alega ter em relação a professores que não são criativos como ele. Como prefere os que são criativos, acaba se afastando dos outros professores da escola e reconhece que isso é, de sua parte, meio preconceituoso. Precisa do reconhecimento dos professores, que prefere para trabalhar junto, e que denomina criativos. Mas, muito provavelmente, quer que sua criatividade seja reconhecida também pelos professores que não o são.

Eu acho que eu tenho, isto daí é uma coisa minha, que acho que é até um preconceito, porque e... eu tenho colegas que são criativissimos. Assim, de um alfinete o cara ensina ótica [...] pelo brilho do alfinete o cara ensina ótica. [...] Mas tem gente que não tem criatividade nenhuma. E eu acabo escolhendo os colegas professores que vão do meu lado, que são aqueles colegas que tem criatividade, aqueles colegas que tem idéias legais. Que pensam em metodologias legais. [...] E aquele pessoal que fica fazendo sempre a mesma coisa. Sempre aquela coisa velha, ensinando coisas como da década de 60, como 
na década de 50 se ensinava... eu acabo até afastando de mim. Então é um negócio meio de preconceito mesmo. [...]

$\mathrm{Na}$ segunda incursão no ensino médio profissionalizante, quando começou adquirir maior confiança com o conhecimento devido ao grupo de estudo, nos traz uma situação em que consegue o reconhecimento dos colegas, por sua ajuda num determinado conteúdo e principalmente de um professor, que colocou à prova sua capacidade de efetuar essa ajuda e que foi obrigado a reconhecer a sua competência. No seu discurso, percebemos a necessidade de nos mostrar o reconhecimento que ele obteve, dos colegas e do seu próprio professor, além de que esse reconhecimento o ajudou a tomar a sua decisão em relação à docência.

[...] dar aula? Eu já tinha experimentado algumas vezes [...] com este negócio do grupo de estudo. A gente sempre acaba adquirindo um conhecimento maior de algumas coisas do que os próprios colegas da classe. Então eu ajudava muita gente dentro da sala. E teve uma certa vez que um professor de química lá, ia ter uma prova tal, não sei o quê. Eu achei que o que o professor tinha passado na lousa uma coisa. Nossa, uma coisa ridícula. E o povo com uma dificuldade doida. Aí eu falei pro pessoal: Se vocês falarem com o professor da aula anterior que era o professor de geografia. Eu explico para vocês como é que faz. O pessoal falou com ele e ele falou tudo bem, mas perguntou: quem que é vai vir, um professor vai vir aqui? Eles falaram não o João vai explicar um negócio para a gente. Aí ele falou: isto eu quero ver. E o professor foi quem fez mais perguntas (risos). Aquele professor fazia tanta pergunta, mas tanta pergunta que teve um aluno da sala que virou para ele e falou: Pô professor, fica quieto. A gente é que quer aprender o negócio, não é você que quer aprender o negócio. Ele falou já que eu estou aqui eu quero aprender. E aí este professor chegou para mim e falou, puxa legal o jeito que você explicou. Os meninos entenderam. Aí eu gostei da coisa. Entendeu? Eu acho que o que me levou a fazer um curso para ser professor.

6.1.3.2 A reedição da situação parental.

A Psicanálise nos diz que o processo transferencial está presente em todas as relações humanas, o que significa uma reedição dos vínculos parentais estabelecidos por nós primitivamente, e que nos dominam quando enfrentamos nossas novas relações (LAPLANCHE; PONTALIS, 2004). Como temos muito pouca consciência da ocorrência destes processos, não temos como prever as conseqüências e, até mesmo, os efeitos de nossos fantasmas em nossas práticas educacionais.

O conceito de transferência nos possibilita entender como estes atuais professores e antigos alunos foram marcados pelos seus próprios mestres na escolha e nas atitudes que empreenderam na sua atuação profissional. A transferência pode ser localizada nas influências sofridas pelos professores por seus antigos mestres, ocasionando a repetição, ou não, dos bons e dos maus exemplos. Se pensarmos na instituição escolar, podemos dizer que, quando a 
criança chega à escola, encontra relações de poder semelhantes àquelas que vivenciou até então no grupo familiar. A escola é um lugar em que esta lógica se repete, em que acreditamos que o professor é fonte de saber e que o aluno entra vazio de experiência e de conhecimento. E é nesta situação que acontece a repetição de uma relação infantil, primitiva, que faz com que o aluno coloque o professor como detentor de um suposto saber, e o toma como modelo a ser idealizado e imitado.

Almeida (1999) nos diz que:

As questões inconscientes que permeiam a relação triangular professor/aluno/objeto de conhecimento remetem ao campo transferencial, que se instaura tendo como base a relação emocional primitiva da criança com os pais. É por efeito da transferência que o aluno se identifica ao professor, fator fundamental para que haja aprendizagem. Entretanto, a paixão transferencial pelo professor deve ceder lugar, em um segundo momento, à paixão pelo conhecimento. Os entraves dessa passagem, no entanto, existem, pois o aluno pode ficar aprisionado pelo viés transferencial, privilegiando sua paixão ambivalente pelo professor e relegando a um segundo plano o interesse pelo conhecimento. Assim, a forma pela qual o professor responderá a esse laço transferencial será de extrema importância para que o aluno consiga realizar essa passagem e liberar seus investimentos libidinais para o trabalho de aprender. (ALMEIDA, 1999, p. 73).

Em muitas situações descritas pelos nossos pesquisados, podemos inferir a possibilidade da reedição da situação parental, a qual corresponde, em nossa análise, em termos de demandas, à crença num controle e conhecimento sobre tudo o que acontece com o aluno, seja na sala de aula, na administração dos conteúdos e, até mesmo, em relação ao seu futuro. Seguindo o nosso modelo empírico já estabelecido no seguimento anterior, podemos dizer que a reedição parental é uma demanda que se localiza no núcleo firme. Na realidade a repetição de cuidados com o aluno, e o saber sobre esse aluno, é semelhante àquele saber e cuidados que a mãe tem com o bebê. O reconhecimento que a mãe espera do bebê também é esperado pelo professor, o vínculo dual parece desejar ser repetido com cada aluno em particular. Essa reedição pode acontecer pela repetição dos cuidados de que foi alvo no inicio de sua vida ou, até mesmo, pela ausência desses cuidados, criando o desejo de que eles tivessem existido. Nos fragmentos a seguir percebemos os professores cuidando dos seus alunos, transferindo e atualizando situações vividas. 


\subsection{Madalena}

Madalena reedita as situações de cuidado com os alunos quando nos fala dos problemas de relacionamento que os adolescentes têm, e sinaliza com um entendimento dual, simbiótico, que parece acenar para um certo jeito de cuidar e ajudar o aluno. "[...] e se você e o aluno se entendem, vocês estabelecem uma relação de simbiose de interesse". Esse cuidado ganha mais sentido quando ela nos conta sobre a adaptação de conteúdos que elabora para conseguir facilitar a vida do aluno, para que ele não sofra para adquirir o conhecimento e que ainda tenha sucesso no futuro. Considerações muito semelhantes a que faz uma mãe.

[...] no cursinho esse conhecimento químico tem uma função muito clara que é para o vestibular, então eu passei a adaptar esse conhecimento, [...] como é que eu poderia distribuí-lo da forma mais eficiente possível para atingir o objetivo daquele ser humano que era chegar ao vestibular e entrar na faculdade. Aí eu descobri os caminhos e (pude) ser clara o suficiente pra fazer ele se dar bem na prova de química e fazer a profissão que ele quisesse.

\subsection{Maria}

Maria conta a sua preocupação em saber se os alunos estavam acompanhando e assimilando, ou não, os conteúdos. Para diminuir essa ansiedade corrigia rapidamente as avaliações que eles faziam para ter controle sobre este fator. "[...] Não conseguia nem dormir sem corrigir prova. Se eu desse prova de noite pra eles, eu tinha que chegar e corrigir, pra ver como eles tinham ido se tinham ido bem se tinham ido mal se tinham entendido o que não tinha".

\subsection{Deise}

Deise nos relata as dificuldades que vivenciou na infância. Mas essas dificuldades tiveram um efeito contrário nas suas atitudes, porque ela não quer que seja reeditada na vida do aluno as dificuldades de que ela foi alvo na sua. Não quer que o aluno sofra e gostaria de ver pelo brilho do olhar dele o seu envolvimento com o conhecimento, como não consegue sente-se culpada. Gostaria de ter um controle semelhante ao de uma mãe, que aparentemente consegue enxergar no semblante do filho o que o aflige. 
[...] se os amigos não estavam entendendo eu ia lá, era coisa minha de querer meio que ajudar o outro no conhecimento, então eu vivi dando aula gratuitamente (risos) para muitas amigas, muitas vizinhas, é uma coisa que sempre me preocupou, sempre procurei lugares para estagiar onde eu tinha que ensinar alguma coisa, então...acho que a vontade de ajudar, de fazer o outro entender e ampliar o conhecimento...[...] como eu sempre gostei disso porque eu sempre fui privada de algumas coisas, já que aprendi a ler com jornal de açougue, não tinha livrinho não tinha nada, então eu queria que os outros, algum dia, conseguissem chegar onde eu cheguei. [...] eu acho (que) essa coisa de ver o brilho nos olhos de alguns...alguns já não são todos mais,...que eu via antes.(É) que eu acho que eu era mais empolgada, né. [...]

Deise também está reeditando a situação parental quando nos conta uma situação difícil, quando estava pela primeira vez na sala de aula "[...] uma turma pesada de escola pública noturno, muitos viciados fedendo maconha $[\ldots]$ " e consegue manter o domínio da situação, porque procura fazer alguma ligação, ou seja, cede um pouco em relação ao que eles querem, para depois manter o controle da situação "[...] aí eu consegui meio que entrar na deles falando um pouco de música, de rock, coisa que eu nem curto [...]”. Isso nos remete, de certo modo, às estratégias que os pais utilizam quando precisam ter controle da relação com o filho, quando sempre têm que ceder em algumas coisas para conseguir adesão do filho a outros compromissos.

\subsection{Jõ̃o}

João faz uma reedição parental quando nos diz que já tem conhecimento sobre como funciona o aluno, como cuidar dele, pois teve uma experiência que deu certo e, ao mesmo tempo, se identifica com as dificuldades financeiras dos alunos já que todos, professor e alunos, vivem na periferia.

[...] pra mim não foi tão difícil porque [...] eu já tinha trabalhado na estação ciência [...] não era professor, mas era monitor [...] eu já tinha desenvoltura na época, então não foi tão pesado [...] e por outro motivo também, eles moravam na Brotolândia e eu também [...] eles moravam no Jardim Soares e eu Morava no Jardim Maria Emília que era outro lugar da Brotolândia e que também era boca quente.

João reedita, na relação com seus alunos, a situação em que se viu obrigado a cuidar da irmã recém nascida, devido ao novo abandono da mãe. No seu relato percebemos o cuidado e responsabilidade que ele teve que ter para com ela. Desiste de esperar pela mãe e encarna todas as atitudes adultas necessárias à situação.

[...] tinha 14 anos, uma irmã de um ano de idade, a qual eu cuidei desde os três meses, quando minha mãe a deixou em casa e sumiu. Ninguém sabia onde ela estava e eu decidi não esperar mais por ela. Levava minha irmã na creche de manhã, ia para a escola, da 
escola ia trabalhar à tarde e ficava no trabalho até as 22:00 h. Morava com minha avó e com meus tios $[\ldots]$.

Estabelece a mesma situação de cuidados com os seus alunos na medida em que se preocupa em fornecer o necessário para que eles sejam letrados cientificamente. Ao mesmo tempo, faz uma critica aos professores que utilizam apenas giz, lousa e saliva e que, mesmo utilizando alguns recursos mais modernos para ensinar, ainda estão, no seu conceito, ultrapassados. Nos descreve como ele age idealmente para conseguir a adesão do aluno para o conhecimento que ele representa. Temos então uma reedição da situação parental porque João está escolhendo o melhor caminho e meios para que a aprendizagem do aluno possa acontecer de uma maneira eficiente. Acredita que os bons resultados dependem dos bons professores criativos que têm diferentes estratégias de ensino, como se os bons pais criassem sempre bons filhos.

[...] Talvez signifique estar com a vida de muitas pessoas em suas mãos. Se você for um bom professor, seus alunos podem estar sendo encaminhados para um lado que poderá deixá-lo em boas condições.[...] acho que é a paciência que ele tem de ter, acho que é a criatividade que ele tem de ter, acho que o conhecimento que ele tem de ter, não só da matéria dela, mas com relação ao que o aluno aprende, o que o aluno não aprende. O que é importante para o aluno aprender [...] Olha, eu to ensinando! Eu dou aula do conteúdo $[\ldots]$ que eles tem que desenvolver. [...] para ser considerado letrado cientificamente $[\ldots]$

\subsubsection{Gozo}

Foi a partir de observações clínicas que Freud (1976) voltou sua atenção ao fenômeno da repetição e, em 1914, ao se deter sobre os fenômenos da transferência na clínica, ele dá à noção de repetição o estatuto de um conceito, porque identifica a compulsão à repetição, como um modo de recordar que surge durante o tratamento analítico. É em 1920, em Além do princípio do prazer, que Freud (1976) nos fala sobre o fenômeno da compulsão à repetição como uma força que sobrepuja o princípio do prazer, e o conceito de repetição passa a ser considerado como constitutivo do próprio conceito de inconsciente, na medida em que revela o movimento da pulsão ${ }^{28}$. Estão intimamente ligados os elementos repetição, inconsciente ${ }^{29} \mathrm{e}$

\footnotetext{
${ }^{28}$ Pulsão é uma atividade que sempre se satisfaz no real. O sujeito está sempre no âmbito da pulsão. A pulsão é uma satisfação acéfala, onde o sujeito não se percebe se satisfazendo de uma determinada forma. A base da pulsão é o gozo, a apalavra, onde o sujeito goza através do blá-blá-blá. É da ordem da pulsão falar, falar, falar; mas não fazer nada para mudar. ( Mrech -1999-p 129-140).

${ }^{29}$ Inconsciente - A noção de inconsciente elaborada por Lacan, em seu primeiro período, apresenta algumas características básicas que são as seguintes: O inconsciente é da ordem da estrutura. Da estrutura estabelecida através da linguagem. O que faz com que seus elementos acabem formando um sistema; $\mathrm{O}$ inconsciente é linguagem e os elementos que ele apresenta são os mesmos da linguagem; $\mathrm{O}$ inconsciente é estruturado como uma linguagem, onde se distingue o significante do significado
} 
pulsão que, juntamente com o conceito de transferência, são considerados por Lacan (1979) os quatro conceitos fundamentais da Psicanálise. A repetição é o que fundamentalmente faz a pulsão de morte, ou seja, relança sempre algo não assimilável, da ordem do real. É este algo não assimilável à cadeia simbólica, traumático, que determina o movimento do desejo, que é sempre desejo de uma outra coisa.

No início das suas pesquisas, Freud (1976) acreditava que os seres humanos fossem governados apenas pelo princípio do prazer, ou seja, que procurassem as situações que fossem ideais; entretanto, foi percebendo que eles poderiam buscar as piores alternativas e, até mesmo, se destruir. A repetição, para Freud, é o gozo ${ }^{30}$ e Mrech (1999) nos diz que não gozamos apenas fazendo sexo, mas com símbolos, fantasias, idéias e que o modo como gozamos instaura uma maneira de funcionamento do sujeito.

Lacan (1985) no seminário XX nos diz que o gozo é uma outra satisfação à qual ficamos atados, uma satisfação que não serve para nada. Segundo Nasio (1993), o gozo é a energia gerada quando o inconsciente trabalha. É o gozo que rege o fluxo da energia psíquica do sujeito, pois há uma determinada forma que os sujeitos repetem sempre para gozar. Existem modalidades de gozo mais positivas e construtivas e outras mais negativas e destrutivas. A característica do gozo é que não temos controle sobre ele e um exemplo disso é aquele sujeito que reclama sempre das mesmas coisas, mas não toma nenhuma atitude para mudá-las.

Em Mrech (1999) encontramos referência ao gozo como uma satisfação pulsional, que leva o sujeito a manter um modo de vida em que não haja mudança, em que não seja feito nenhum investimento energético, em que haja apenas um dia-a-dia que continuamente se repete, em que ele se alegra e se queixa sempre das mesmas coisas, de uma forma alienada. $\mathrm{Na}$ sala de aula, o professor, nessa situação, tenta, de certa forma, não se culpar, mas, ao mesmo tempo, vai se culpando dos eventos que não consegue controlar. Como se culpa, está sempre pronto a racionalizar e contar uma história coerente. Vira um peso insuportável empreender qualquer ação, estabelecer qualquer relação, fazer qualquer trabalho. É o momento em que o professor atua por inércia. Ele está em sala de aula, mas, muitas vezes, não sabe o que está acontecendo.

\footnotetext{
${ }^{30}$ Gozo - Modalidade de funcionamento do sujeito. O gozo no sentido lacaniano não é o gozo do prazer que obtém através do orgasmo ( sentido tradicional da cultura). É o gozo obtido através da linguagem e da palavra. O gozo é uma outra satisfação. Uma satisfação obtida através do inconsciente, através da linguagem e da fala, frente a algo onde o sujeito não deveria estar sentindo prazer. É por isto que Lacan fala de uma outra satisfação. Uma satisfação que não serve para nada, mas que mantém o sujeito atado às suas cadeias. Onde o sujeito goza, goza sem parar. Um prazer inconsciente que emerge da manutenção da inércia. Um prazer inconsciente que se encontra vinculado à libido fixada, fazendo com que o sujeito repita sempre os mesmos contextos, as coisas da mesma forma. (Mrech, L. M. Psicanálise e educação: novos operadores de leitura. São Paulo: Pioneira, 1999.p. 129-140).
} 
Segundo Scotti (2003)

A culpa aparece, então, como corolário estrutural que se mostra como signo de um gozo, que se mantém na oscilação mesma entre ser o falo para o Outro e o desaparecimento do sujeito como sujeito do desejo, o que é evitado por medidas restauradoras que buscam recolocar o Outro em seu devido lugar através de expedientes defensivos como a denegação, a anulação, o isolamento.(ibid., p. 219).

Para uma melhor observação das situações de gozo no discurso dos professores, ou seja, para que seja possível verificar a linha de raciocínio que se repete na fala do sujeito, utilizaremos trechos maiores, que possibilitam perceber melhor o desencadeamento das idéias.

$\mathrm{Na}$ análise dos eventos já classificados no capítulo anterior, a demanda que nos parece ter referência no elemento psicanalítico gozo, é a culpa. E segundo nosso modelo empírico, essa culpa estaria no cinturão protetor, que diz respeito às justificativas que o professor faz na tentativa de explicar a sua falta de controle sobre as situações de ensino, sobre o aluno e, principalmente, em busca de proteger as demandas do núcleo firme.

\subsection{Madalena}

Madalena se justifica muitas vezes no seu discurso, mas principalmente em duas situações muito marcantes e conflituosas. Na primeira, seu discurso de autoridade não foi respeitado e a frustração chegou a gerar até sintomas físicos. Na segunda, os alunos querem fazer o mínimo esforço e solicitam respostas das questões que deveriam pesquisar para a avaliação. Com a pressão dos alunos sobre a coordenação do curso, ela se demite, mas, como tem que continuar até o final do semestre, usa o fato de não ter mais vínculo em seu favor para obter dos alunos auto-suficiência em relação aos estudos. Faz muitas considerações sobre as duas situações, sente-se culpada e rejeitada, mas tenta relativizar a culpa, tecendo uma série de justificativas sobre o fato de terem sido experiências sem sucesso. Se culpa ainda porque existe a possibilidade de que não consiga abordar os conteúdos de maneira eficiente para prender o interesse do aluno. Quer ter uma eficiência sem limites, quer ter o poder de controlar todas as variáveis da aprendizagem, quer salvar o mundo; a impossibilidade a faz sempre se culpar pelo que crê que poderia e deveria ter sido feito.

[...] uns dois maus momentos, o primeiro foi assim [...] tinha a turma que assistia aula $\mathrm{e}$ tinha a turma da sexta feira do bar [...] eles estavam meio que obrigados ali [...] um aluno ficou bravo [...] disse que eu estava dando muito conteúdo [...] Ai eu falei pra ele, olha 
bicho, é que cursinho é assim[...] ele me deu uma resposta grosseira[...]você é vagabunda[...] eu disse companheiro você sai, ele disse eu não vou sair [...] pegou a carteira e jogou no tablado, aí veio o dono da escola, mas eu nunca tinha vivido aquilo.[...] eu me comprometi a continuar [...] e eu vomitava antes de entrar nessa turma [...] Acabou tudo se ajeitando, mas eu acabei me demitindo de lá porque achava que eu não estava sabendo lidar com esse descaso.

[...] E outro momento ruim [...] a escola estava muito preocupada porque [...] estavam perdendo alunos para essa outra universidade [...] a gente sofria uma pressão muito grande e os alunos obviamente percebiam isso [...] quando chegou na primeira prova [...] eles se indignaram, [...] como é que ela tinha dado uma prova daquele tipo [...] eu fui intransigente com relação ao meu conteúdo. [...] eu pedi demissão (mas) fiquei até o final do semestre [...] eu sou demissionária, mas vocês vão ter que me agüentar [...] e dei todo o conteúdo ao qual eu tinha me proposto.

Optamos, agora, por repetir integralmente as considerações que Madalena fez para que

o próprio texto fale por si sobre as cadeias que vão se mostrando, e que a aprisionam, nessa preocupação em atender o aluno de maneira ilimitada e perfeita:

[...] Agora (o que aconteceu) tanto no primeiro quanto no segundo caso a minha preocupação era com o conteúdo, né, de que eu não estava ali novamente pra ganhar um dinheirinho, eu tinha uma função ali, no caso do pré-vestibular era transmitir aquele conhecimento de Química para que os alunos fossem aprovados e no caso do bacharelado que eu achava que era muito mais sério, se eles não sabiam cálculos estequiométricos eu ensinava eu não tinha essa intolerância, só que se eu ensinava eles tinham que me dar provas de que houve um aprendizado e tal, e na verdade o que estava acontecendo com a faculdade é que ela estava abrindo mão da avaliação. [...] embora você encontre várias justificativas para aquela situação ruim ter acontecido no fundo você se sente de alguma forma culpado e no fundo você se sente de alguma forma profundamente rejeitado e isso incomoda, só que dessa vez (na faculdade) eu consegui trabalhar isso de uma maneira muito suave fui até o fim do ano, não tive ulcera não passei mal e acabei dando o curso, né? Só que também nessa turma não era tão unânime como foi na outra a rejeição, né, essa era assim tinha uns focos eram os lideres que conseguiram carregar alguns, mas_a maioria ficou comigo, lá não, foi exatamente ao contrário eu fiquei com a minoria no cursinho, né! e a maioria ficou na rua, talvez tenha sido mais traumático né, são os momentos ruins. Agora são dois momentos ruins contra um montão. Eu me vejo assim, uma pessoa extremamente responsável, preocupadíssima com o que eu estou falando, se o que eu estou falando está certo mesmo, né, preocupada se ele está aprendendo, eu me culpo demais, é muito difícil eu achar que a classe é uma porcaria, né, eu posso até falar isso mas quando eu vou voltando pra casa, eu falo: onde é que eu estou errando? Eu sou muito preocupada com o conteúdo e sou muito preocupada com assimilação, né? Eu acho que eu sou muito séria, às vezes até intransigente com algumas coisas, porque sou muito perfeccionista com a minha função, entendeu? Parece que eu salvo ou não salvo o mundo. Sabe assim... Exagerado. Eu sou muito ética, né! Isso é assim é norma de vida minha, assim se eu tenho que estar fazendo alguma coisa, eu tenho que saber se vai prejudicar alguém, eu tenho que saber qual é o peso dessa palavra, eu sou incapaz de fazer uma piada racista, eu não tolero piada racista, né! Eu preciso ser a melhor professora eu preciso transmitir tudo eu não fico conformada com o mais ou menos e eu acho que essa aí sou eu, é como eu me vejo. 


\subsection{Maria}

No discurso de Maria encontramos muitas situações em que ela se coloca aparentemente vivendo em culpa. O que significa que existe uma necessidade de se justificar, um gozo que se faz presente em torno da sua relação com a sala de aula, com a escola e com a sua vida pessoal. Isto se configura numa situação de gozo, pois é um discurso recorrente e não aparece uma solução, só um desenrolar de considerações sem fim. Em relação à escola, culpase porque tem que impor limites aos alunos, mas, ao mesmo tempo, se justifica porque não quer estar judiando deles; na seqüência vem a culpa que lhe é imputada pela escola por não conseguir o envolvimento deles. Sente-se culpada, também, por não dar conta de todos os conteúdos e, na tentativa de suavizar esta culpa, justifica dizendo da sua competência e honestidade na sua relação com os alunos, já que gostaria de cumprir todos eles. Maria se culpa também por não ser mais tão jovem e não conseguir dar conta de todos os desafios que lhes são colocados. Agora se sente mais cansada e sabe que a escola quer vitalidade e não experiência. Justifica que sua energia não deve ser gasta com passeios, que ela considera não educativos, mas com os Estudos do Meio. Justifica-se dos motivos pelos quais desistiu de dar aulas na rede Estadual e no movimento de explicações que se desencadeiam, percebemos que se culpa por ter desistido do Estado; e racionaliza os motivos que a fizeram desistir dos alunos das escolas públicas, que, provavelmente, são os mais órfãos de bons professores. Existe ainda, permeando todas as considerações que já fizemos, uma justificação em relação ao fato de estar em época de obter a aposentadoria e de ter resolvido fazer um Mestrado.

Eu me preocupo com o que eles aprendem [...] ele passou pela minha mão e não ficou melhor do que ele era antes[...] Eu não quero judiar, eu quero formar. [...] Se não pegam o caderno é culpa minha, eu que não influencio, [...] Se por acaso não dá tempo de eu ver alguma coisa [...] aquilo me incomoda extremamente [...] eu me responsabilizo pela sala [...] Pode ser a última vez na vida deles que eles tenham Química [...] com a experiência que eu tenho hoje, mais nova. [...] E eu acho que uns cinco seis anos atrás eu era melhor [...] tenho medo de não apostar numa sala novinha como essa, entendeu [...] gostaria de ter mais vitalidade[...] Quer que eu vá pra um Hopi Hari [...] Eu faço estudo do meio! Estudo do meio, não é passeio [...] eu sinto que to ficando inflexível em algumas questões da escola [...] tudo nas costas do professor [...] eu também larguei o Estado, porque o Estado também não tava sério [...] Os meninos não sabiam o que significavam as palavras [...] foi esse o ano que eu pedi minha exoneração.[...] Hoje, os alunos formam-se e, praticamente de imediato, já ingressam no Mestrado. Claro que analiso isso com aspectos positivos e negativos, pois quando se tem mais experiência eu acredito que se valoriza mais o que se faz [...] me dediquei [...] em adquirir experiência, fazer cursos de atualização como professora, [...]. Tenho um grande amigo [...], que costuma dizer que eu procurei tanto me especializar em como dar aulas, que esqueci de mim mesma, do crescimento de minha carreira [...] Gostaria de me aposentar como professora de Ensino Médio e ingressar em uma boa faculdade. 


\subsection{Deise}

Acompanhando as argumentações de Deise percebemos que se culpa por não controlar a indisciplina em sala de aula. Isto faz com que entre numa cadeia de gozo, de justificações e de aparente busca de soluções para o problema. Vai fazendo uma relação com as modificações que seriam necessárias que fossem feitas nela e em sua prática, para conseguir bons resultados, mas, ao mesmo tempo, argumenta as dificuldades de empreender essa mudança. Culpa-se porque não estuda mais, o que poderia, talvez, melhorar sua argumentação em sala; se pune porque não encontra mais brilho nos olhos dos alunos e isso ela acredita que acontece porque ela mudou, porque não é mais tão empolgada como no início da docência. Culpa-se também por não conseguir cumprir os projetos que pareceram possíveis nos primeiros dias de aula e que poderiam ter gerado um maior envolvimento dos alunos e uma nova relação com a sala. Olhando a descrição de Deise observamos essa recorrência de argumentações sobre a necessidade de estudar mais, fazer mais projetos. Ela acredita que esses elementos podem ajudá-la a conseguir maior controle sobre a indisciplina e, assim, quem sabe, recuperar o brilho dos olhos dos alunos. Gostaria de ser aceita por ela mesma, ou seja, que os alunos gostassem dela o suficiente para evitarem serem indisciplinados e que não fosse necessário se impor de nenhuma forma.

Sua pulsão é viver em busca de meios para resolver o problema da indisciplina, se mantém numa situação de gozo porque quer acreditar que a possibilidade de conseguir êxito com a indisciplina depende apenas de que ela estude, cumpra o planejamento e seja mais rígida. Ou seja, acredita que esses elementos sejam capazes de resolver o que mais a incomoda em sala de aula, a sua crença de que não tem controle sobre a disciplina dos alunos. Sonha com uma situação ideal em que não precise sofrer tanto, se culpar, e que seja aceita como ela é.

[...] agora o problema da indisciplina é um problema meu que me atrapalha e com as novas gerações parece que está sendo pior, e quando eu não consigo fazer com que a classe fique envolvida [...] (quando) eu vejo que não tão muito aí [...] eu fico muito frustrada, eu não consegui resolver isso [...] eu acho (que) essa coisa de ver o brilho nos olhos de alguns...alguns já não são todos mais [...]eu era mais empolgada, né [...] ando lendo menos eu acho que eu devia ler mais porque eu aí (ia) ter argumentos melhores para discutir com os alunos [...] Engraçada ....as vezes chata e ..não tão rígida como deveria ser . [...] Mais rígida, mas não rígida só pelo ...mas ter um respeito maior pelo que eu sou [...] aceitação só pela minha pessoa ..que fosse suficiente, mas ai eu tento contornar isso lendo estudando [...] pra conseguir trabalhar com os alunos [...]mais atividades mais projetos , mas o tempo vai passando e agente vai deixando a coisa 


\subsection{João}

O gozo de João é estar em dívida com o conhecimento científico. Desde o primeiro relato, na sua História de Vida, indica como necessidade básica para o professor, além do amor, conseguir transmitir o conhecimento científico desde que ele tenha capacitação para isso.

[...] me lembro é que um dos meus professores de Física não era capacitado para lecionar Física. Tanto que ele não sabia me tirar nenhuma dúvida de qualquer parte da Física que não tinha a ver com o que ele tinha dado. Digo isso porque eu já havia tentado tirar dúvidas com ele.

Fala sobre sua necessidade de ajudar o aluno na aquisição do conhecimento científico e esse gozo é percebido, principalmente, no fato de que o seu trabalho do Mestrado tem como tema o letramento científico. Podemos imaginar o quanto essa preocupação aparece nos seus discursos endereçados aos alunos, aos seus pares, à instituição e para a pesquisadora.

[...] Olha, eu to ensinando ! Eu dou aula do conteúdo. Eh, eu tento fazer com que os alunos desenvolvam as competências que eles tem que desenvolver. As habilidades que eles tem que desenvolver. Pra eles serem considerados...depois ter um conhecimento básico para ser considerado letrado cientificamente (que é o negócio da minha dissertação) mas que eu acredito nisto. Eu geralmente tô fazendo isto porque eu acredito que o aluno ele pode ser, ele pode ser letrado cientificamente. Ele pode ter conhecimentos básicos para entender coisas básicas, fenômenos básicos da vida dele, que envolvem ele. $[\ldots]$

Critica os professores que apesar, do conhecimento cientifico, não sabem utilizá-lo de maneira criativa, como ele e alguns professores conseguem fazer. Coloca-se como preconceituoso em relação a esses professores que não sabem, ou não usam, as metodologias de ensino mais modernas, para a transmissão eficiente desse conhecimento. O seu gozo está em se colocar numa condição especial, preconceituosa, em que determina quem estará com ele na disseminação eficiente utilizando as modernas tecnologias.

[...] isto daí é uma coisa minha, que acho que é até um preconceito, porque e... eu tenho colegas que são criativíssimos. Assim, de um alfinete o cara ensina ótica [...] pelo brilho do alfinete o cara ensina ótica. [...] Mas tem gente que não tem criatividade nenhuma. $\mathrm{E}$ eu acabo escolhendo os colegas professores que vão do meu lado.

[...] Por exemplo, o modo de apresentar a ciência, seja de uma forma tradicionalíssima: giz, lousa e saliva...Seja de uma forma um pouco menos tradicional, mas ainda tradicional, que é você colocar no... colocar na transparência, e projetar na lousa, e tal. Botar num data show, sei lá, e colocar lá. [...] Tem uma coisinha mais, ou uma coisinha a menos, que é uma animação, uma coisa diferente e tal, mas é o modo de você apresentar. Então é assim. Mas, o simples fato de você não estar escrevendo com o giz na lousa faz com que o aluno veja em você um professor diferente, porque todos os professores que eles viram até agora fizeram isto. Entendeu? São poucos os professores que utilizam meio multimídia, que utilizam outras coisas assim. Principalmente quando você vai e faz uma experiência com eles. Você demonstra uma experiência para eles. [...] 
João mostra que seu gozo está em tentar incluir os outros professores da escola em atividades do conhecimento científico. Ele se empenha em mostrar a validade e eficiência dessa situação de ensino, sobre o conhecimento físico, chegando a ponto de profetizar que esse tipo de atividade de aprendizagem pode levar os alunos a escreverem, e até a fazerem contas, melhor. Para João, o conhecimento científico parece estar suprindo todas as suas faltas, e a imagem que fica é de que tudo é possível, levando-se em conta esse conhecimento.

[...] Eu disse (para as professoras) que eles podem fazer aquelas experiências de Ciências que está no site da Faculdade de Educação da USP. Eu passei aquelas filmagens (das atividades de conhecimento físico ${ }^{31}$ ) para umas quatro professores da primeira até da terceira série. As professoras olharam aquilo e ficaram maravilhadas. Disseram-Puxa vida que legal! [...] -Mas isso aí é uma coisa que não dá para fazer dentro da sala de aula. Eu disse -Mas como é que não dá para fazer dentro da sala de aula? Se eles fizeram dentro da sala de aula da periferia do Rio Pequeno, do Butantã. Puxa vida! Claro que dá, lógico que dá! - Elas disseram- Mas não tem o material e tal. Então eu disse -A gente produz o material, é simples pra caramba. E outra coisa, vocês querem o material? O material que ela usou? Eu fui lá na Faculdade de Educação, catei o material, coloquei dentro do carro levamos para as professoras de lá. As professoras fizeram, e disseram que eles fizeram uma molhadeira dentro da sala [...]a molecada ficou pintando os desenhinhos. Eu falei Gente. Olha só para os trabalhinhos que essa molecada faz. Porque esses professores em vez de ficar gritando com essa molecada, não dá um negócio desse pra essa molecada se divertir. Vai dar problema para você limpar a sala depois, mas, claro que vai. Mas, puxa vida, é uma coisa tão construtiva. A molecada aprende tanto e a gente vai ter tão pouco problema quando essa molecada chegar no ensino fundamental. Porque eles chegam com um olhar diferente. Eles conseguem escrever de uma forma diferente, consegue até fazer conta de uma forma diferente.

No trecho seguinte, extraído da História de Vida, João nos mostra como o conhecimento científico foi importante na sua vida, como a sua visão de mundo sofreu modificações a partir dele, portanto, existe um gozo em ter essa dívida simbólica.

No curso de Física, aprendi a pensar mais longe. A analisar coisas de diversos pontos de vista e a conviver com o aprendizado a toda hora e a qualquer minuto, em todos os meus atos e na análise dos atos das pessoas, principalmente dos meus alunos.

\subsubsection{Dívida Simbólica}

Por que um adulto, seja pai ou professor, é levado a ocupar uma posição educativa? Essa é pergunta feita por Lajonquière (1999) e que nos é respondida dizendo: que é para saldar uma dívida, pois o professor ensina por dever e o aluno é movido por amor na sua tarefa. "Ensinase por dever, aprende-se por amor". Lajonquière (1999, p. 173).

\footnotetext{
${ }^{31}$ Inserção explicativa feita pelo pesquisador
} 
Além das pequenas escusas da nossa vida cotidiana, os adultos se endereçam às crianças na esperança de vir a saldar uma dívida simbólica que, outrora na sua infância, contraíram com aqueles adultos significativos para eles. Como sabemos, todos deixamos na vida alguma conta pendente no cartório das expectativas parentais. Independentemente de nosso esforço, da magnitude das dívidas e da teimosia cobradora, sempre se decanta a experiência subjetiva de que estamos em dívida para com eles. (LAJONQUIÈRE, 1999, p.173)

Esta dívida foi contraída na infância, nas nossas primeiras relações parentais, fomos, de certa forma, seduzidos por outro adulto nas origens e temos agora à nossa frente um aluno que também se tornará devedor. A Educação submete o aluno a outro que encarna a autoridade. Lajonquière (1999) caracteriza a educação como uma sedução que envolve ao mesmo tempo domínio, poder, e iniciação. Diz que temos uma dívida com as expectativas que os pais tinham em relação ao nosso futuro e, independente, do nosso esforço em saldá-la, sempre haverá uma sobra a ser paga. A Educação é um dos meios que se utiliza na tentativa de vir a repor algumas dessas pendências, isto quer dizer, educa-se em nome da dívida que se recebeu de um outro, que também tinha uma dívida de mesma natureza.

O que toda educação tenta repor é experimentado como falta, que é creditada como um fracasso educativo, porque quando um pai educa um filho transmite uma dívida existencial, então, ele deve a seus próprios pais, porque eles deixaram a desejar em relação à educação que receberam, e essa educação se revelou fracassada porque não conseguiu dar ao seu avô o sucesso imaginário. $\mathrm{O}$ que acontece é que cada um está educando do lugar da dívida do seu pai, imaginando como seu próprio pai teria pretendido educar.

Segundo Birman (1994), o sujeito não tem como negar essa dívida simbólica, que contraiu como resultado de sua constituição como sujeito, ou seja, a dívida desde sempre contraída por nossa condição humana de falantes a partir do Outro. Essa dívida simbólica possibilita a constituição de um pacto simbólico entre os diferentes sujeitos, dando chance ao surgimento dos laços sociais.

Essa dívida simbólica também é elemento que aparece muito nas narrativas dos nossos pesquisados. Como já discorremos em inúmeras passagens do texto, sobre o nosso modelo, essa dívida se localiza no núcleo firme, e diz respeito às apostas que a família fez no nosso sucesso futuro. Vamos observar, agora, como os nossos pesquisados fazem referência a essa dívida simbólica. 


\subsection{Madalena}

Madalena tem uma dívida simbólica com os pais, que sempre lhe mostraram a importância do estudo, mesmo sendo eles apenas alfabetizados. Apoiaram suas escolhas e abdicaram de desejos pessoais para que ela pudesse só estudar em tempo integral. Diz que escolheu Química “[...] porque a professora de Química do ensino médio era excepcional_[...] tinha uma capacidade de nos encantar com a Química”. Mas percebemos que esta dívida, por ser encantada pela professora com o conhecimento científico, ela tenta pagar, pois, no seu discurso, aparece uma preocupação reincidente de também encantar os seus alunos com a Química. "[...] O que mais me encanta na minha profissão é a generosidade impregnada nela, pois se aprende para se poder transmitir, estuda-se para aprender coisas novas e devolvê-las aos alunos de uma forma que os encante [...]".

Para o professor uma demanda importante é tentar pagar essa dívida simbólica com os adultos que apostaram nele. Uma tentativa dessa quitação é o fato de os professores ensinarem os conteúdos do conhecimento que eles representam. Segundo Kupfer (2000), a relação com o conhecimento faz com que o sujeito tente suprir a sua falta transferindo esse conhecimento e deixando herdeiros. Portanto, ser professor significa poder fazer a renovação de votos com o conteúdo, com o conhecimento científico, o que lhe proporciona um certo gozo e isso acontece no espaço da sala de aula.

\subsubsection{2- Maria}

Maria, no seu texto, descreve a impagável dívida que tem para com seu pai, porque desde a sua infância ele a incentiva com leituras. "[...] sempre fui muito estimulada à leitura, a ter tido sempre um acompanhamento muito próximo principalmente de meu pai, que foi e tem sido um orientador em meu percurso". Esses livros eram disponibilizados e era questionada sobre a sua interação com eles. "[...] Desde pequena, livros e pequenas coleções acompanharam minha vida, conversas sobre o que eu havia lido, o que eu havia gostado mais (Coleções como Tesouro da Juventude, Monteiro Lobato, depois Shakespeare fazem parte dessas lembranças)".

O pai era um modelo, mesmo em aspectos negativos. 
[...] Antes de entrar na escola, eu brincava que era professora, [...] tinha a idéia de que professor era muito bravo, talvez por meu pai ser muito severo nos limites que nos colocava, então, além de pedir giz à minha mãe, eu tinha também uma régua para bater na cabeça das crianças que me desobedecessem. Que coisa louca, não é?

Tinha sempre a ajuda do pai nos estudos. Apenas no colegial, quando ele não consegue acompanhá-la, ela passa a estudar como os colegas. "[...] Não me lembro de estudar freqüentemente em grupo, meu pai costumava me ajudar nas minhas dúvidas, apenas no colegial comecei a estudar Física com alguns colegas, já que a esta altura, meu pai já não se lembrava de Física para me ensinar”.

Maria é tão ligada na figura do pai que só consegue fazer sua escolha profissional definitiva após receber o seu aval. Percebemos no fragmento do primeiro parágrafo, em que ela se refere ao pai como orientador de seu percurso, que ela volta a repetir essa idéia de orientador quando se refere ao professor de Química. Por isso, nos parece que a dívida simbólica que ela tem com o seu pai está tentando pagar demonstrando gratidão pelos professores, nos quais ela via, aparentemente, o modelo do pai. Possivelmente também por essa razão, tenham conseguido torná-la devedora em relação ao conhecimento científico. Essa divida com o conhecimento ela tenta pagar ensinado Química e influenciando seus alunos a se tornarem devedores escolhendo profissões ligadas à Química.

[...] em Química, tive professores extremamente exigentes, mas [...] nos quais eu conseguia ver uma razão para tanta exigência. Um dos meus professores [...] nos fazia mostrar as mãos depois das aulas de laboratório, se estivessem manchadas, éramos descontados, tínhamos que trabalhar com método e cuidado e isso me ajudava a acompanhar melhor as experiências, entender o que ele queria que víssemos ou verificássemos[...] Fui fazer Química porque eu era apaixonada pelos professores de Química que eu tive, eu acho[...]Foi muito marcante um professor de Biologia, que eu tive[...] muito bravo ele era,mas ele orientava, orientava mais do que tudo.[...] [...] minhas tias [...] eram todas professoras [...] me diziam assim: - [...] isso é uma armadilha, no começo é bom[...] cê nunca vai ganhar o que cê acha que ce merece[...]. E o meu pai falou para mim, faz o que você quiser. Aí foi quando eu fiquei [...]

[...] Muito bons momentos foi ter alunos que vieram falar pra mim que vão fazer Química, Engenharia Química, Bioquímica... Que... Graças a Deus isso acontece até hoje. Quer dizer, você de certa forma acaba influenciando positivamente esses meninos.[...].

\subsection{Deise}

O fato de ter sofrido privações, mas ter conseguido acesso ao conhecimento, a coloca em situação de pagamento simbólico dessa dívida. Muito cedo ela tenta fazer esse pagamento, quando é incentivada pela mãe a ajudar crianças carentes a ler e a escrever. Essa dívida faz com que ela esteja sempre desejando facilitar o caminho para os seus alunos. A primeira 
conquista que o conhecimento científico fez sobre ela, nos parece dizer respeito a situação que contou em sua história sobre a chegada do homem à lua. Mas a conquista definitiva aconteceu numa feira de ciências, quando, aparentemente, começou a perceber as possibilidades que o conhecimento científico oferecia para uma ampliação da sua visão de mundo.

[...] Eu, desde pequena gostava de... compartilhar aquilo que eu aprendia [...] para muitas amigas, muitas vizinhas[...]sempre procurei lugares para estagiar onde eu tinha que ensinar alguma coisa[...] vontade de ajudar, de fazer o outro entender e ampliar o conhecimento[...] porque eu sempre fui privada de algumas coisas[...] aprendi a ler com jornal de açougue, não tinha livrinho não tinha nada, então eu queria que os outros algum dia conseguissem chegar aonde eu cheguei.

[...] sou Química e poderia dar aulas de Física, eu já dei aulas de Física no começo de minha carreira, mas eu acho que não seria bom eu dar aulas de Física porque precisa conhecer mais a fundo a disciplina, não é só ir lá e jogar as formulinhas.[...] muito marcante uma feira de ciências no Anhembi ,quando eu estava no ensino fundamental na 6.a ou 7.a serie [...] quando eu falei eu quero fazer ciência eu quero trabalhar [...] na área de ciência, porque eu via que a coisa do conhecimento, de conhecer mais coisas eu via o mundo maior do que eu estava acostumada na escola [...] isso foi marcante o professor pegando seus alunos enfiando num carro e levando no Anhembi, nunca fui em feira nenhuma.

\subsection{Jõ̃o}

João tem uma divida simbólica, que se inicia com as suas professoras primárias; a professora que fez com que ele perdesse o medo da Matemática; e, depois, com os seus bons professores. Esses professores, em que ele se espelha, que acreditaram nele e lhe proporcionaram a oportunidade de estudar em uma universidade pública. Agora ele, como devedor, quer fazer o mesmo pelos seus alunos, na tentativa de saldar essa dívida. Também deve o amor que, de certa forma, conseguiu dessas pessoas e que se traduziu pela confiança de que ele poderia ter um futuro.

No seu relato, essa dívida está traduzida na expressão em que diz que não quer de modo algum que algum aluno caia na besteira de achar que não consegue entrar numa universidade pública. João segue os seus modelos, literalmente, já que hoje em dia trabalha na mesma instituição que eles, e procura fazer pós-graduação porque esses professores, na sua maioria, já a fizeram. João demonstrou, em várias ocasiões no seu relato, a importância que o conhecimento científico específico tem para ele, quando critica os professores que não sabiam transmitir o conhecimento por não serem formados para aquela disciplina específica. Como conseguiu adquirir o conhecimento científico necessário para assumir a profissão, e estar ao lado dos seus modelos, ele tem dívida. Essa dívida ele tenta pagar ensinando Física e fazendo 
com que seus alunos sejam letrados cientificamente, o que, inclusive, é o tema que ele desenvolve nos seu trabalho de Mestrado.

[...] minhas professoras do pré acreditaram que eu tinha um papel muito importante na sociedade [...] Meu medo de Matemática acabou [...] professora Rosa foi quem [...] me ensinou Matemática de uma forma muito mais prazerosa [...] Hoje sinto um prazer enorme em trabalhar com ela na mesma escola.

(A) [...] pessoa que me ajudou na escolha desta profissão foi uma professora de Educação Artística [...] a professora Eliana. [...] Era a professora que cuidava de seus alunos como se fossem seus próprios filhos [...] quando eu entrei na Universidade, ela foi a única pessoa dessa época que me cumprimentou, dizendo que já sabia que eu me daria bem em qualquer coisa que eu escolhesse na vida.[...] Foi aí onde eu conheci os cinco professores que mais me apoiaram na empreitada de prestar um vestibular [...] e fazer um grupo de estudos aos sábados, para que algumas pessoas pudessem entrar na Universidade.

[...] O amor faz as pessoas acreditarem em um objetivo e lutarem por ele [...] Minha formação foi um misto de espelho dos meus antigos professores e agora amigos [...] sou um professor de Física que acredita nos meus alunos e não deixo que nenhum deles caia na besteira de não acreditar que são capazes de fazer um curso na USP ou em qualquer faculdade pública. É muito provável que uma das minhas alunas de suplência preste vestibular, pois eu e outros professores estamos incentivando e ajudando muito esta menina.

[...] Nenhum dos meus professores soube ser convincente naquilo que fazia. Sem contar que depois eu fiquei sabendo que alguns destes professores estavam lecionando a matéria que eles não tinham formação.[...] Este foi o caso de um professor de estatística básica que tive neste curso. Só depois que eu soube que ele era mestre em Biologia pela USP. Me perguntei: "o que ele está tentando fazer ao dar aula de estatística?[...] O Luis também tinha o seu diferencial, apesar de eu não conseguir entender nada de Física que ele me ensinava. Não é à toa que eu prestei para química na primeira vez.[...] Neste ano, o Luis que era tecnólogo na sua formação, entrou na USP para fazer um curso de Licenciatura. Segundo alunos amigos meus que estavam tendo aula com ele, ele estava melhorando muito seu método de ensino. Por isso eu me empolguei mais ainda para fazer um curso de licenciatura na USP e estudei bastante para isso.[...]

Um dos professores do grupo de estudo, com quem ele tem maior dívida, é o de História, porque esse professor chegou a pagar as suas inscrições nos vestibulares para que ele experimentasse o que era fazer o exame. $\mathrm{O}$ objetivo era de que ele perdesse o preconceito, o medo e passasse a acreditar na sua possibilidade de ingresso. O professor acabou reforçando a dívida simbólica e o fez determinar-se a saldá-la. Nos conta, em seu relato, que, a partir daí, o seu destino estava selado, ou melhor, foi selado por seus professores. E ele, como bom pagador de dívida, começou a tentar pagá-la.

[...] este cara (o professor de História) chegou para mim e falou, meu, vai, presta e vê [...] Eu falei, mas cara, não tenho dinheiro, não to trabalhando, to desempregado, vou fazer como ? O cara foi e pagou a minha inscrição. Pagou o manual de duas universidades. Pagou o da PUC e o da USP para eu fazer. Aí eu falei:-agora que você pagou eu vou fazer é ? Não era para você fazer isto. Aí o cara falou : Não mas agora eu já fiz. Vai lá e faz. Então eu vim e fiz. Quando eu percebi que num era bicho de sete cabeças entrar na Universidade de São Paulo. Aí eu coloquei na minha cabeça que eu ia entrar. Eu falei:-eu vou entrar.

Então acho que vou ser professor porque acho que professor é uma coisa legal. Eu tracei esta meta porque..., na verdade quem traçou este caminho para mim não fui eu. Quem 
traçou este caminho para mim foram professores meus. E eu acabei gostando do caminho. Eu olhei assim e falei: Puxa é legal, vou fazer um negócio deste mesmo. Gostei da idéia. Tanto que quando eu prestei (em 97) de tanto os caras ficarem martelando na minha cabeça para eu entrar numa universidade pública, eu entrei em cinco. Eu entrei aqui, na Unicamp, na Unesp, na Fatec e na Federal de São Carlos, na Federal de Santa Catarina. Nas cinco.

Mostra no fragmento a seguir que uma outra maneira de tentar pagar a sua dívida simbólica, incluiu ser modelo e incentivo para os demais membros da família. Quer mostrar as possibilidades que estudar proporciona e, ao mesmo tempo, também colocá-los como devedores em relação ao conhecimento.

Então acho que assim: a minha família, minha mãe, eu acho que eles gostam de ter uma pessoa da família que é professor, que fez faculdade e agora está fazendo Mestrado e provavelmente mais para frente vai fazer Doutorado, né. Então, uma pessoa que é letrada na família. Eles me chamam de catedrático.(risos).

Então, por ser o sobrinho mais velho, o neto mais velho, $[\ldots]$ sou arrimo da família. O povo se apóia, até os tios se apóiam em mim. Eu tenho esta tia que voltou a estudar. Tenho uma outra tia que eu estou enchendo o saco dela para voltar a estudar. E ela é inteligente pra caramba, tem muito conhecimento. Fez curso de enfermagem, fez um monte de coisas. É uma pessoa que evolui.[...] minha família gosta de ter um professor na família. Principalmente para ajudar os primos (risos). 


\subsection{CONSIDERAÇÕES SOBRE A UTILIZAÇÃO DO REFERENCIAL PSICANALÍTICO.}

Organizando e atualizando o modelo com o qual viemos trabalhando até aqui, introduzindo os elementos da Psicanálise, podemos considerar que, no núcleo firme, encontramos elementos que se configuram como demandas, que foram estabelecidos a partir das imagens iniciais criadas com as Histórias de Vida e com as entrevistas. As demandas que diziam respeito a ser reconhecido e amado e, principalmente, em ser um competente porta voz do conhecimento científico, se traduziram, na nossa interpretação, pelo elemento psicanalítico demanda de amor. As demandas que diziam respeito a pagar a dívida para com os que apostaram nele, e também com o conhecimento científico, corresponderam ao elemento psicanalítico dívida simbólica. Para pagar essa dívida, o professor quer tornar o aluno também um devedor porque tenciona deixar herdeiros do conhecimento, assim como foi herdeiro de seus pais e professores. Quando as demandas diziam respeito a controlar o ensino, a aprendizagem e os impasses da sala de aula, a relação que estabelecemos foi referenciada com a reedição da situação parental, a qual diz respeito a uma espécie de repetição das regras que estavam postas desde que nasceram e que os controlaram, e continuam controlando, durante toda a sua vida. E, finalmente, quando a demanda dizia respeito a se culpar e justificar, encontrando álibis para a sua atuação, a nossa referência se apóia no elemento psicanalítico chamado gozo, pois o professor está em situação de gozo quando se propõe a achar justificativas e tecer longas considerações sobre o que acontece em sala de aula.

O que nos parece possível inferir, até o momento, integrando os elementos psicanalíticos ao nosso modelo, é que esses quatro elementos correspondem a demandas que o sujeito busca atender de todas as formas. Então, no núcleo firme, ou seja, nessa instância imaginária que o professor se põe e que parece garantir a sua permanência na docência, estão colocados os elementos psicanalíticos: demandas de amor, reedição da situação parental e dívida simbólica. Esses três elementos se constituíram como demandas a serem atendidas através do conhecimento científico, que colocou o professor na posição de sujeito de suposto saber. Diante de sentimentos de insegurança que surgem devido à falta ou incompletude de qualquer dessas demandas, ele entra em cadeias de gozo, em que emite considerações sem fim e em que não consegue promover, aparentemente, nenhum movimento de mudança. As infinitas justificativas que são criadas, com o objetivo de proteger as demandas do núcleo firme, paralisam o sujeito em situações de gozo até que ele consiga se deslocar desse gozo 
para outro. O que parece estar buscando, quando faz emergir do seu discurso essas demandas, é a obtenção de uma situação de plenitude capaz de suprir todas as suas faltas.

Se perguntarmos novamente qual a natureza desse compromisso e o que poderia estar subjacente a ele na escolha profissional, poderíamos responder, agora, que esse compromisso é subjetivo e caracterizado por demandas que foram referenciadas nesses quatro conceitos da

Psicanálise, devendo, portanto, estar relacionadas à possibilidade de reedição, de pagar a dívida, de ter amor, reconhecimento, e de obter um gozo. Então, subjacentes a esse compromisso estão as demandas subjetivas do sujeito que datam da sua própria constituição.

Acreditamos que a Psicanálise ampliou a nossa possibilidade de compreensão, pois coloca as situações e os conceitos num plano em que o sujeito não tem acesso, ou seja, não adianta o sujeito perceber o que lhe falta, onde erra, ou exagera para fazer algum reparo. Simplesmente não pode considerar que sabe o que realmente deve ser feito para mudar e conseguir bons resultados, pois não dá para mudar o núcleo firme. Principalmente porque o sujeito não tem acesso ao que ele mesmo colocou inconscientemente nessa instância imaginária. Se fosse permitido ao sujeito fazer uma opção racional, ele teria a chance de fazer mudanças a qualquer momento. Mas, como para o sujeito perceber sozinho as cadeias que o prendem é quase impossível, ele não muda.

Então, utilizando a imagem do modelo de Lakatos, conseguimos estabelecer uma relação entre as demandas subjetivas e inconscientes do sujeito, que estão no núcleo firme e o cinturão protetor, onde estão as justificativas sem fim, que protegem o que está no núcleo de ser atacado.

\subsubsection{Ampliação dos resultados da análise.}

Estamos a um passo de estabelecer as conclusões que se tornaram possíveis a partir dos dados que selecionamos. Entretanto, nesse momento, resolvemos retomar alguns fragmentos das análises que tínhamos empreendido sobre Histórias de Vida de professores da educação infantil e do ensino fundamental. Apesar desses dados terem sido descartados logo no inicio do trabalho, percebemos que eles são relevantes no que diz respeito ao atendimento das demandas e aos elementos que utilizamos da Psicanálise. Faremos, brevemente, algumas considerações sobre esses fragmentos da entrevista de pelo menos um desses professores, no caso Julieta, 23 anos, professora de educação infantil. 
[...] Acho que a maioria das pessoas que são professoras, são professoras por isso! Minha mãe é professora, e eu fui alfabetizada muito cedo, eu tinha quatro anos, eu lia, escrevia, então eu gostava muito de brincar na lousa e brincar de ser professora. Mas eu nunca achei que eu fosse ser professora por isso. E aí, na verdade eu me tornei professora porque eu fui praticamente obrigada pela minha mãe a fazer magistério, porque ela achava que era uma profissão onde eu trabalharia meio período, então era uma coisa legal, né! Trabalhar meio período, se eu tivesse filhos eu teria mais tempo para os meus filhos, e tal.

As demandas que fizeram sentido nas histórias dos professores que trabalhamos até aqui, também fazem sentido na história dessa professora. Julieta fala sobre a dívida simbólica que adquiriu para com a mãe que, praticamente, a obrigou a entrar nessa profissão. Percebemos a aposta que a mãe fez na filha, alfabetizando-a aos 4 anos e depois argumentando sobre os benefícios da profissão para uma mulher que, mais cedo ou mais tarde, tivesse que trabalhar meio período, se casasse e tivesse filhos. A mãe acreditava que o que foi bom para ela deveria ser bom para filha também. A filha, como boa pagadora, faz Magistério, vai para a sala de aula e ainda volta a estudar para conseguir o diploma de Pedagogia.

[...] Eu não sei, mas as crianças gostam muito de mim, sabe? São muito apegadas comigo, embora eu seja um pouco rígida com eles, seja até brava, eles gostam muito de mim [...] Aonde eu vou eles vão, eu sento eles brigam pra sentar perto, aquela coisa [...] eu acho legal trabalhar com criança, porque as vezes você não tá legal, você vai trabalhar, você não tá muito legal, mas a criança vem te dá um beijo, te dá um abraço, te elogia.[...] Pela minha diretora eu sou tida como uma boa professora. Inclusive ela sempre me dá aquelas classes bombas né? Aquelas coisas. Porque acho que por eu ter essa postura aí de de de colocar limites. Então ela...Os diretores tem uma outra visão né? Eles preferem que esteja tudo bem. Que não haja bagunça tal tal tal. Mas eu acho que... Eu acredito que eu sou vista como uma boa professora. Eu acredito que possa melhorar. Mas eu acredito que eu sou vista como uma boa professora

Conta como as crianças gostam dela, mesmo sendo um pouco 'brava'. Que querem estar sempre perto dela dando abraços e beijos e, ainda, conseguindo influenciar seu humor, pois o carinho e amor que eles lhe dedicam conseguem animá-la. Ela também tem o reconhecimento dos diretores da instituição em que trabalha, justamente por esse seu lado, meio repressor, de colocar limites nos alunos. Com certeza a demanda de amor que faz, e que parece estar sendo atendida pelos alunos, direção e provavelmente pelos pais, lhe proporciona uma grande satisfação, uma sensação de completude.

[...] você também tem que compreender que a criança tem tudo ao seu tempo, né? [...] E todo o dia você vê a criança evoluindo, aos pouquinhos, às vezes aquela criança que não saí do lugar, de repente ela dá um salto gigante. Isso é muito gratificante né? [...] Que todo dia você vê uma coisa que você acha que você contribuiu praquela criança [...] Às vezes você começa a trabalhar com a criança no começo do ano e ela não consegue escrever o nome. Aí você vai, você ajuda tal tal tal, dias depois você vê que ela ta 
escrevendo, que ela ta escrevendo sozinha, a criança nota que aquilo é positivo pra ela né? Então essas conquistas diárias que eu acho que ainda me mantém professora [...]

Aqui aparece a reedição da situação parental porque a professora se preocupa em tentar entender a criança, da mesma maneira que faria uma mãe. Considera que a criança tem um tempo, só dela, para fazer alguma aprendizagem. Maravilha-se ao ver as mudanças 'milagrosas' que acontecem quando um aluno que não sabia escrever, começa de repente a escrever o seu nome. Nesse caso, ela está novamente tentando pagar a dívida simbólica, porque está iniciando essas crianças na linguagem e, portanto, tornando-as devedoras.

[...] Então eu tento sempre melhorar. Ser autocrítica, perceber o que que eu tô errando, o que eu não to e mudar minha postura [...] eu gostaria, até de ser menos brava com as minhas crianças sabe? Gostaria de poder dar mais liberdade pra eles e tal. Mas ao mesmo tempo eu penso que é difícil, porque as crianças também abusam né? Se você dá muita liberdade pra eles, eles... eles abusam.[...] Então eu gostaria disso. E como postura é isso, de... de ser mais leve com as crianças, sabe? Ás vezes eu acho que eu pego pesado com eles né? Afinal eles são crianças né? Então é isso.[...] Que eu acho que atualmente a escola faz até o papel que a família não faz, né? Então acho que eu sou educadora, porque você educa a criança pra várias coisas né? (...) A gente ajuda a criança a construir conhecimento e construir valores e tal, né? [...] Então você [...] nunca pode desistir daquilo, né? É uma coisa, é uma conquista diária, é uma coisa que você tem que conquistar diariamente $[\ldots]$

No fragmento acima aparecem situações de gozo que permeiam a relação da professora com os seus alunos. Nelas, ela se culpa porque acredita que precisa melhorar, saber quais os erros que está cometendo, ser mais paciente, dar mais liberdade, pegar menos pesado porque são crianças. Mas, ao mesmo tempo, sabe que precisa ter pulso firme para que elas não abusem. Essa preocupação com os limites existe porque acredita que a família não está mais fazendo o seu papel, então ela tem ajudar a criança com o conhecimento e com a "construção de valores". Enfatiza, no seu discurso, a impossibilidade de desistir das crianças, que na realidade considera como suas; da sua responsabilidade em educar; de dar amor; de às vezes cuidar um pouco mais do que a própria família “[...] eu gostaria, até de ser menos brava com as minhas crianças sabe?". Ela vive esse dilema, mais ou menos parecido com aquele que as mães vivem por temerem serem rígidas em demasia e, por vezes, deixarem os filhos muito soltos. Essa culpa é recorrente no seu discurso, porque aparentemente não quer perder o amor que lhe dedicam, nem tão pouco o reconhecimento institucional pelo seu pulso firme com eles.

O que podemos inferir dessa análise é que, em maior ou menor grau, os professores, sejam eles devedores de qualquer conhecimento, estão sempre, inconscientemente, em busca de satisfazer essas demandas. Consideramos, então, que a generalização dessas demandas pode ser possível para todos os professores que se encontram atuando. 


\section{CONSIDERAÇÕES FINAIS}

As nossas considerações finais, ao mesmo tempo em que mostram a trajetória da pesquisa que nos possibilitou chegar a algumas conclusões sobre a manutenção do professor na situação docente, também levantam hipóteses; corroboram a escolha dos dados quando confrontados com a própria História de Vida da pesquisadora; tecem diálogo com outros trabalhos que respondem questões similares, como o de Arruda e Ueno (2003); e exploram, ao máximo, analogias feitas a partir dos Programas de Pesquisa de Lakatos. Aliás, em relação a esse modelo, a analogia foi feita, inicialmente, com a imagem do cinturão e do núcleo, levando em conta a proteção que o cinturão deve exercer sobre o núcleo, exatamente porque as demandas dos sujeitos deixavam transparecer a necessidade de proteção de alguns elementos fundamentais para a profissão.

Após a entrada dos elementos psicanalíticos nas análises, houve uma ampliação da analogia com o modelo, utilizando as relações que Lakatos estabeleceu entre cinturão e núcleo. Tentamos, agora, nas conclusões, fazer um estreitamento dessa analogia definindo até onde essa interpretação pode avançar.

$\mathrm{Na}$ primeira parte deste trabalho, acompanhamos a trajetória de vida de quatro professores. Nesse caminho, buscamos apreender o cenário de vida que cada um quis nos mostrar, bem como as imagens que se preocuparam em destacar sobre a sua profissão. As Histórias de Vida dos pesquisados nos revelaram alguns passos marcantes dessa trajetória, pois, apesar de ser particular o que foi revelado de cada sujeito, alguns elementos se repetiram nas diferentes histórias. Durante essa verificação, nos prendemos nos deslizes de linguagem, nos movimentos, nas descontinuidades e nas repetições.

Organizamos as Histórias de Vida utilizando e estruturando a Análise do Discurso em cenografias, ethos pré-discursivo e ethos discursivo, conforme Maingueneau (2005). Observamos, principalmente nos ethos discursivos, elementos que, de certa forma, aparecem marcados em todas essas histórias, e os interpretamos em termos de demandas que os professores apresentam para o atendimento a instâncias mais subjetivas. Para obter uma segurança maior na interpretação, realizamos uma segunda tomada de dados, com os mesmos sujeitos em entrevistas semi-estruturadas. Essas entrevistas vieram a fortalecer as categorias empíricas que tínhamos criado. Olhando para as demandas que o sujeito fez ao contar sua história, seja na História de Vida ou nas entrevistas, percebemos o quanto foi frutífero referenciar tais demandas de natureza subjetiva nos elementos psicanalíticos, que se 
constituíram num espaço teórico capaz de ampliar o entendimento dessas imagens que insistiam em se fazer presentes.

Posteriormente, devido à interpretação que ganhava força sobre o fato de existirem elementos fundamentais que deveriam ser protegidos, foi possível elaborarmos um modelo interpretativo criado em analogia ao de Lakatos.

Os quatro elementos que a Psicanálise nos emprestou - dívida simbólica, reedição parental, gozo e demanda de amor - nos ajudaram a entender alguns dos indícios que nos chamaram a atenção sobre as razões pelas quais o professor permanece na profissão, e quais os mecanismos que podem estar agindo inconscientemente para que isso ocorra. Pudemos inferir, com o auxílio desse referencial, utilizando o primeiro elemento, que professores estão na profissão, e nela se mantêm, provavelmente, para pagar a dívida simbólica que foi contraída no inicio da suas histórias como sujeitos. Dívida que foi estabelecida pela família, desde quando estavam sendo gerados e que lhes possibilitou a entrada no mundo de relações e de conhecimento, para que viessem a ocupar o lugar que lhes destinaram. Foram colocados como devedores, e continuarão sendo devedores durante toda a vida, apesar de estarem sempre tentando fazer a quitação. Uma tentativa de pagamento é deixar os alunos como herdeiros do seu conhecimento e, portanto, dessa dívida, assim como eles próprios são herdeiros dos seus pais e dos seus professores. O segundo elemento destacado foi a reedição parental, que diz respeito à situação de repetição de cuidados que receberam, ou não, desde a relação parental. Querem, assim, fazer com os alunos uma repetição desses cuidados e, ao mesmo tempo, dos limites que a família lhes colocou.

Essa situação transparece, também, na preocupação que o professor tem em manipular os conteúdos para que o aluno aprenda sem sofrimento. Não desistem de tentar a efetivação da aprendizagem, pois acreditam que sempre vai existir uma saída, mesmo que o discurso oficial que profiram seja outro. Têm paciência em esperar resultados, ainda que criando condições imaginárias para obter sucesso no ensino, o que pode ser traduzido por uma esperança sem limites. O terceiro elemento foi o gozo, que tem a função reparadora de aliviar um pouco da tensão para que o professor possa fazer um novo investimento no problema e que se revela nos sentimentos de culpa, na repetição das mesmas queixas e dos mesmos esquemas de fuga. $\mathrm{O}$ quarto elemento foi a demanda de amor, que diz respeito à necessidade de reconhecimento irrestrito por todos os envolvidos no processo educativo.

Ao estabelecer essa relação com os conceitos psicanalíticos, conforme já havíamos anunciado anteriormente, retomaremos alguns aspectos de nossa própria História de Vida (Anexo 2). Ela foi escrita com o objetivo de se tornar algum tipo de parâmetro ao qual a 
pesquisadora pudesse se remeter, caso necessário. Observamos que nossa história também respondeu às categorias empíricas e aos elementos utilizados da Psicanálise e que os motivos que aparecem de maneira explícita, ou velada, nas histórias de outros professores também nos remetem à nossa permanência na docência. Portanto, de alguma forma, a nossa história corrobora e dá sentido à incursão que fizemos nas histórias de outros sujeitos.

\subsection{MAIS UMA HISTÓRIA DE VIDA}

A pesquisadora foi criada em uma família desestruturada em muitos aspectos e, talvez, pelos mesmos motivos de João, tenha uma necessidade acima da média de aceitação e reconhecimento. Portanto, uma grande demanda de amor. Na infância, sentia falta do amor de seus pais e de seus professores. Só vai conseguir as primeiras retribuições dos seus professores no final do primário, quando descobre que tem algo que pode ser valorizado: a sua desinibição. O episódio da formatura, relatado abaixo trouxe à tona sua fragilidade em não suportar dividir o amor dos alunos. Mostra, também, o descontrole que essa situação pôde gerar, quando foi pega de surpresa, o que acabou ocasionando uma exposição excessiva e desnecessária diante dos alunos.

A minha mãe era totalmente impulsiva, sem nenhuma razão aparente, pegava uma vara de bambu e ia nos batendo, quem fez e quem não fez apanhava, nós implorávamos para ela parar, mas como boa italiana, nem pensar.[...] Acho que fomos criados por dois insanos. O castigo era o único contato físico que tínhamos. Não ganhávamos beijos nem abraços, nem nos davam a mão para andar na rua, ou melhor, nunca saíamos com eles e as mãos deles, no caso, estavam sempre ocupadas em carregar o bebê mais novo. Andávamos em bando e sozinhos. Fazíamos coisas erradas, é claro, mas morríamos de medo das conseqüências, isto eu posso dizer em relação ao meu pai, porque, em relação à minha mãe, o que dá para perceber é que ela não tinha nenhuma lógica nas surras que nos dava. [...] Nessa escola eu não me sentia privilegiada, eu não tinha visibilidade, e sabia perfeitamente que as queridinhas dos professores eram a Eva (uma menina alemã) a Graziela (uma italiana) e a Ester (uma portuguesa), portanto não tinha espaço pra mim.

[...] Foi nessa época que eu descobri que isso podia mudar. Tão logo apareceu o primeiro evento cívico, eu fui a única a me oferecer para declamar e, a partir daí, nunca mais eu fiquei, até acabar o científico ${ }^{32}$, sem falar, declamar, plantar uma árvore ou hastear a bandeira num evento cívico. Não preciso dizer que eu li o discurso de formatura do primário e que eu nunca vou me esquecer, quando a professora pediu para que eu lesse o discurso para os outros professores da escola, para mostrar como eu tinha jeito com as palavras. Não esqueço dela dizendo: - Prestem atenção como ela diz essa parte... (Me senti muito especial).

[...] Depois de tanto tempo em sala de aula (como professora), uma certeza que eu tenho é o fato de querer e, precisar do amor e do reconhecimento de meus alunos.[...]

\footnotetext{
${ }^{32}$ Científico- os três anos finais de escolarização antes do ingresso no terceiro grau. Atualmente corresponde ao colegial.
} 
principalmente no momento em que surge o incômodo da falta ou da dúvida da existência desse amor.[...] Fui escolhida como paraninfa [...] Esse clima de amor eterno estava indo muito bem até que [...] descobri, naquele instante, que eu não seria a única paraninfa. Aquilo me pegou tão de surpresa que a minha primeira reação foi de uma infantilidade [...] Eu disse:- Gente, eu não estou entendendo. Vocês passaram o ano se queixando do Carlos, dizendo que não entendem o que ele fala, que ele não gosta de responder perguntas, que ele é um 'grosso'. Acho que vocês precisam saber escolher as pessoas que realmente estão preocupadas com vocês e....depois de uns cinco, digamos dez, talvez mais, minutos de descontrole e desabafo eu pude finalmente enxergar a 'cara' que eles estavam me olhando. Evidentemente eu tentei, sem cortar o discurso, salvar a situação dizendo que não custava nada eles terem me dito isto antes, afinal de contas, eu gostava muito do Carlos, mas eu podia não gostar e aí.......desatei a falar de várias outras situações que me vieram a mente. [...] Depois de eu (acho) ter mostrado para eles que eles também podem ser egoístas, fiquei mais calma. Não me senti mais tão 'malvada'. Não me conformo até hoje dessa minha reação absurda. Tudo porque eu não tinha dúvidas de que eu era a única, aquela que tinha o reconhecimento sob forma de todo o amor que eles poderiam me dedicar.

A pesquisadora reedita a situação parental porque vive tentando cuidar dos seus alunos, apesar de ter vivido essa situação às avessas, já que não acredita que algum dia tivesse sido cuidada ou tivesse recebido amor dos seus pais. Ao mesmo tempo revela que gosta de cuidar e ensinar, porque cuidou de seus irmãos quando eram pequenos e sempre os auxiliou na escola. Reedita também a crença que tem no futuro dos alunos, na capacidade de mudança de posição em relação ao conhecimento porque, em sua vida, sempre encontrou pessoas que apostaram nela.

[...] não me lembro de ter sido cuidada. O que me lembro é de ver a minha mãe sempre cuidando de um bebê e dos cascudos que eu levava para me afastar deles, quando eu era muito pequena, porque depois, quando eu cresci um pouquinho, passou a ser uma das minhas obrigações cuidar deles. Não me lembro de meus pais terem sido carinhosos comigo, parece mentira, mas não me lembro. [...].Era muito estranho para mim, quando eu estava no primário e tinha que entregar o cartãozinho do dia dos pais ou das mães. $\mathrm{O}$ que acontecia é que eu ficava o tempo todo ensaiando como eu ia entregar, já que não tinha nenhuma intimidade ou afeto por eles, eu acho. Eu não me lembro de ter sido cuidada, amada ou acariciada.

[...] Não preciso dizer que sempre estudei com os meus irmãos, que todos sempre confiaram que eu podia ajudá-los com o conhecimento e tenho certeza que até hoje é assim.

[...] Os professores, na sua maioria, (não consigo me lembrar de nenhum que não tenha feito) faziam ótimos prognósticos sobre o meu futuro. [...]

[...] Hoje estou sempre marcando as situações que são importantes, criando um 'caminho' para que a aprendizagem aconteça e acredito estar sendo seguida pelos alunos.[...]

Acreditamos que o gozo da pesquisadora está em ter controle sobre como ela ensina, quando, e o que o aluno deve aprender. Quando fala da sua sala de aula está sempre buscando demonstrar que, de alguma forma, exerce esse suposto controle e, para isso, utiliza um discurso com os alunos buscando conquistá-los para que se coloquem, mesmo que temporariamente, disponíveis para a aprendizagem. Às vezes reconhece que, mesmo fugindo 
ao seu controle, algumas situações têm sucesso. Apesar disso, sua crença na idéia de que exerce um papel imprescindível para seus alunos permanece. Não se sente segura em dar tempo ao aluno para ele investir na busca de suas próprias respostas, porque não quer que ele sofra, ou desista, de forma alguma.

[...] Estou sempre marcando as situações que são importantes, criando um 'caminho' para que a aprendizagem aconteça e acredito estar sendo seguida pelos alunos. Essa crença vem do fato de que eu sempre estou atrás deles perguntando alguma coisa, olhando o que estão fazendo, mantendo contato, querendo saber das opiniões sobre as dificuldades com o conteúdo, comprometendo-os a ajudarem uns aos outros, ou seja, fazendo uma marcação cerrada para ter o máximo de controle sobre o que está acontecendo. Agora, eu quero 'morrer', quando no dia da avaliação eu percebo que eles não conseguem resolver situações que foram exaustivamente tratadas em sala de aula, ou que não se lembram dos detalhes que eu deixei bem marcados para se pensar o problema. Primeiro surge a sensação de frustração porque não tenho todo o controle que acho que tenho, depois me culpo por não ter esse controle. Continuo me culpando porque eu queria poupá-los de uma decepção com a nota e com a Física; depois finalmente me culpo por ter que atribuir notas baixas, porque na realidade não tenho segurança de qual é a minha parcela de culpa ou não sobre o que aconteceu. Depois disso começo uma nova empreitada em busca de bons resultados com os alunos, para aliviar essa culpa.

A pesquisadora tem dívida simbólica com a professora primária, que mostrou que ela tinha valor por saber ler muito bem e ser desinibida; com as professoras do ginásio, que lhe proporcionaram uma situação de ensino muito marcante e que confiaram em sua capacidade de dar conta de uma experiência como professora; e, principalmente, dívida com os bons prognósticos feitos em relação ao seu futuro como, por exemplo, os de seus professores e do Sr. Atílio. Foi obrigada a admitir, inclusive, durante a análise de sua história, que até seu pai fez apostas no seu futuro e, portanto, tem dívida para com ele também.

[...] nunca vou me esquecer [...] para mostrar como eu tinha jeito com as palavras [...] Prestem atenção como ela diz essa parte... (Me senti muito especial).

[...] Foi nessa época que aconteceu algo muito marcante e que acredito definiu o meu caminho como professora. As minhas professoras; de literatura, dona Darcy e; de desenho geométrico, dona Zulma, da terceira série ginasial (7.a série hoje) se preocupavam que, devido às circunstâncias, eu como filha mais velha, dos oito filhos, talvez tivesse que começar a trabalhar e estudar à noite. Ainda no ginásio, resolveram então me indicar com 13 anos de idade, como professora, para os filhos de famílias ricas da cidade para dar aulas particulares de todas as disciplinas e, esse foi o meu trabalho até os 15 anos. É claro que a partir daí sempre estava dando aulas de reforço para alguém, apesar de nessa época (15 anos) eu ter começado, porque não tinha jeito, a trabalhar num depósito de ração para animais, como auxiliar de escritório.

[...] bons prognósticos pelos meus professores ou pelo Sr. Atílio, os quais eu acreditava piamente que se concretizariam. Sou obrigada a admitir que até meu pai via um futuro brilhante para $\operatorname{mim}[\ldots]$

Em relação ao conhecimento científico, visto como uma dívida simbólica, demonstra ser uma ótima representante, porque consegue fazer com que não tenham medo da Física, que encarem esse conhecimento sem traumas e que, mesmo sabendo que muitos deles não serão 
Físicos, sente um imenso prazer em mostrar como os conceitos dessa disciplina podem ser utilizados em cursos que eles jamais teriam imaginado.

[...] Uma situação que me enche de orgulho é quando meus alunos declaram que desejam serem Físicos, ou quando querem saber o que pode haver de conteúdos de Física em medicina ou direito. Principalmente porque essas questões, que eles me fazem, não têm nada a ver com o fato de não gostarem da disciplina, mas com a possibilidade de que no futuro, nessa profissão poderão aprender mais sobre o assunto. Gosto de ver a tranqüilidade com que eles lidam com o conhecimento sobre Física. Não tomam esse conhecimento como um 'bicho de sete cabeças', não se colocam na posição de acreditar que é impossível aprender os seus conteúdos. Acho que o que eu mais gosto em mim, como professora, é o meu jeito de ser porta voz desse conhecimento, de conseguir tornálo palatável e acessível.[...]

Olhando para os elementos psicanalíticos revisitados na História de Vida da pesquisadora, nos colocamos também como parte dos dados, já que toda escolha e interpretação, subjetivamente, foram definidas a partir do nosso olhar. Portanto, assim como os pesquisados, também estamos em busca de pagar a dívida com os que acreditaram em nosso sucesso; de reeditar situações de cuidado e regras que foram estabelecidas na convivência dentro da família; de necessitar de amor e reconhecimento de todos na escola; e de utilizar esquemas inconscientes de gozo para não desistir das demandas, até que elas sejam imaginariamente atendidas.

\subsection{ANALOGIA COM ARRUDA E UENO (2003)}

Com vistas à verificação do potencial explicativo das nossas conclusões, estabelecemos relações e analogias com o trabalho de Arruda e Ueno (2003) com o objetivo de fazer uma reflexão sobre as razões subjetivas da desistência e da permanência dos alunos num curso de Licenciatura em Física. Nesse artigo, realizam um estudo de caso com um aluno do primeiro ano e utilizam, também, várias entrevistas com alunos ingressantes e de outros anos do mesmo curso.

Como um entre os resultados iniciais apontados pelos autores, surge a necessidade no discurso do aluno de ser reconhecido, por ter feito a opção de cursar Física, como algo que foi considerado pelos colegas "com um valor a mais [...]" (grifo nosso). Segundo análise empreendida, concluíram que "o conhecimento e/ou o reconhecimento pelo outro, de alguma forma preenche a falta do sujeito (ou momentaneamente o distrai de sua falta), que ele se satisfaz com o ato de estudar, aprender ou ensinar". (grifo nosso) 
Na nossa interpretação, essa necessidade de reconhecimento pode ser lida como uma demanda de amor e o conhecimento científico que o aluno anseia em obter - estudando, aprendendo - se constitui numa tentativa de preencher a sua falta.

Quando fazem referência a uma distração momentânea que parece uma distração da falta, no nosso caso, interpretamos como situações de gozo que paralisam temporariamente o sujeito até que ele busque uma nova situação, também de gozo. Há grande coerência, nesse aspecto, com o que analisamos no nosso trabalho, pois inferimos que o conhecimento científico perpassa todas as demandas subjetivas do sujeito. Assim, esse conhecimento se constitui numa possibilidade do sujeito obter reconhecimento, ou seja, atender sua demanda de amor.

Extraímos do texto situações em que verificamos a necessidade de reconhecimento, a necessidade de cuidar e de ser cuidado, ou amparado por um amigo, como numa reedição da situação parental e, ao mesmo tempo, atender sua demanda de amor e ainda pagar uma dívida simbólica com os familiares que apostaram que ele teria condições de adquirir um status social com o conhecimento científico. Apesar de, muitas vezes, esse não ser o conhecimento desejado e planejado pelos pais, o aluno não consegue fugir dos seus desígnios e vai em busca dele.

[...] quando eu entrei, eu conheci um amigo meu que, nossa! A gente fez uma amizade assim, muito diferente das amizades que eu tinha tido antes, uma amizade de lealdade, de confiança assim, sabe.[...] É uma coisa muito boa, quando ele está desanimado do curso, eu vou lá, e o animo, e aí quando eu estou desanimado ele vem e me anima. [...] Então eu penso: se eu desistir do curso, assim, que eu vou me afastar também dele, e ele pensa a mesma coisa, aí eu penso: será que se eu fizer um curso, será que eu ia encontrar outra pessoa? Então ele me ajuda a ficar no curso, e ao mesmo tempo eu o ajudo. [...] na casa dele [do amigo] ninguém quer que ele faça o curso. O pai dele é médico e ele fala assim: "é, você vai ser pobre", sabe, fica falando assim. Queria que ele fizesse medicina e há uma pressão na casa dele também muito forte, sabe. "Eu construí tudo isso pra você, e você só vai decair" e aí ele tem medo de fazer a Física, e abaixar o padrão de vida dele.[...] É, no começo a minha mãe, ela não queria, preferia que eu tivesse escolhido outra coisa, só que ela também não fala. [...] ela não queria que eu fosse professor, só que, ela não se intromete no curso.

Esse reconhecimento e amor que o aluno deseja, em que seja visto como competente, não diz respeito somente à relação com os colegas, mas também com o professor. No relato abaixo verificamos o sofrimento em que ele se coloca na busca do atendimento a essas demandas.

O professor B1 tinha mania de fazer pergunta na sala, né, durante a aula, ah, eu vou fazer uma perguntinha e aponta. Ele começou a pegar no meu pé. Quando estava chegando na aula dele, eu já começava a ficar nervoso, tenho gastrite. Meu estômago começava a queimar. Durante a aula, eu não conseguia mais prestar atenção, porque eu ficava com medo da hora em que ele fosse me fazer pergunta, porque por mais que eu soubesse a 
matéria, eu não conseguia responder mais. [...]. A análise dele, se o pessoal está indo bem ou não, é durante as perguntinhas. Se ele vê você respondendo certo, você está indo bem, você está estudando. Se não, você não sabe nada. É mais ou menos isso. Eu ficava com medo de não conseguir responder, e aí, ele achar que eu não sabia nada. [...].Quando estava chegando o horário da aula dele, eu ficava com a mão gelada, começava a me dar dor de estômago. Na hora que começava a aula, eu ficava de um jeito assim, eles falavam comigo, eu não escutava nada, nem a matéria dele, não conseguia prestar atenção, de tão nervoso que eu ficava.[...] O jeito com que o professor trata você é um dos fatores, que faz você desistir. Eu vi tanta gente da minha sala, que eu vi que era bom, que tinha futuro, desistir por causa dele. Por causa do jeito dele.

Observando, ainda, as justificativas do aluno A1, que foi o do estudo de caso, pudemos perceber no seu discurso a mesma linha de queixa, quando ele relata sobre as dificuldades que lhe foram mostradas, por inúmeras pessoas, por escolher física. Apesar do aspecto "conseguir a admiração dos colegas pela escolha desse conhecimento" existe uma justificativa exacerbada sobre o desafio que tem que vencer. Existem muitas previsões apostando na sua desistência do curso. Quando ele se coloca justificando isso muitas e muitas vezes, se configura uma situação de gozo. Para exemplificar essa situação utilizaremos o discurso que aparece no texto do aluno A1.

[...] pra desistir do curso de Física, pra mim, tem que ter mais coragem do que pra continuar o curso. Porque se eu desistir, eu tenho que fazer outro curso, eu vou ter que enfrentar outro vestibular, sentar naquela cadeirinha [...] além de eu gostar (da Física, o curso), tornou-se um desafio, porque todo mundo fala: você não vai conseguir se formar, é muito difícil. A minha professora, eu tive a mesma professora nos três anos de $2^{\circ}$ grau, e ela falava "não faz", sempre que eu ia conversar com ela, "é muito difícil, se formam pouquíssimos alunos, você não vai conseguir". [...] Então, além de eu gostar do curso, queria fazer porque eu gostava, eu queria aceitar como um desafio. Por que eu não vou conseguir? [...] quando a gente tem uma força de vontade, como eu assim, eu entrei, eu quero fazer Física e vou fazer, tem aquele monte de gente assim: "você não vai conseguir, você não vai conseguir, não vai conseguir", então eu fico assim, não, mas se eu desistir agora, todo mundo vai ficar: "eu não falei que você não ia conseguir, você perdeu tempo, não falei?" Então eu falo: eu vou conseguir e vou para frente. [...] Ah, se eu desistir, eu vou dar razão para o que eles estavam falando. É lógico, se eu desistir, se eu quiser mesmo desistir, eu não vou falar que eu vou desistir por causa do que eles falavam, só que é uma das coisas que junto com tudo aquilo.[...]

Na nossa interpretação, esse gozo é o que mantém o sujeito nessa situação de busca de conhecimento, enquanto ele tiver álibis e considerações a fazer sobre o porquê não pode desistir, isso não vai acontecer. Todas as situações cruciais que coloquem em questão as demandas serão amenizadas com a pulsão de gozo.

Os autores concluem o trabalho tecendo considerações sobre o desejo de ser professor, que aparece implícito no desejo desse aluno.

[...] em relação ao desejo de ser professor, ele parece remeter à relação do sujeito com o outro, ou talvez mais exatamente, com o desejo de ser reconhecido pelo outro. Assim, o que eu quero é ser reconhecido como 
"melhor", com um valor a mais, pelos meus colegas. [...] para a psicanálise, o desejo vai além desse plano imaginário e aponta para uma falta fundamental: o desejo do sujeito é o desejo do Outro (Lacan). Ou seja, o desejo teria a ver com uma escolha inconsciente, envolvendo uma satisfação também inconsciente e da qual resulta a persistência, o esforço, o investimento pessoal nas atividades do aprendizado em uma disciplina.(ARRUDA; UENO, 2003)

Nesse ponto, as análises do nosso trabalho e a dos autores ganham o mesmo sentido, porque, conforme nossa interpretação, os professores estão atendendo às demandas imaginárias que os remetem à relação com o outro. Se levarmos em conta o desejo do sujeito, temos que considerar que ele é o desejo do Outro, portanto as escolhas e as satisfações são inconscientes. O professor, quando deseja a situação de completude, ou seja, busca atender e proteger as demandas imaginárias, está fazendo escolhas e obtendo satisfações inconscientes.

O que podemos considerar, paralelamente ao nosso trabalho, é que o aluno também está colocado numa situação similar à do professor, já que as demandas que o sustentam em busca do conhecimento são de mesma natureza. Possivelmente esse aluno, após ganhar o status que o conhecimento científico lhe proporciona, de professor, entrará pela primeira vez em sala de aula e em contato com uma situação muito promissora. Situação essa capaz de dar atendimento às suas demandas subjetivas e que, para ser preservada, também vai colocar em ação os seus esquemas de gozo.

Estabelecendo relações sobre os motivos pelos quais os alunos desistem do curso de licenciatura, com aqueles que levam o professor a desistir da sala de aula, podemos estabelecer as considerações descritas a seguir.

O aluno desiste do curso, segundo os autores, porque, inicialmente, tinha algumas expectativas como suprir a sua curiosidade, gostar de resolver problemas, fazer cálculos matemáticos e, ainda, o desejo de ser reconhecido pelos colegas e pelo professor. Consideram o “desejo do aluno em relação ao conhecimento físico, que poderíamos denominar de desejo de saber Física, que parece vir articulado com o desejo de ser professor, no caso da opção pela licenciatura. De fato, o desejo de ser professor parece vir articulado a um desejo relacionado ao conteúdo [...]" (grifo nosso). Podemos dizer que o excesso de tarefas, a dificuldade com o próprio conhecimento da física, a intransigência de alguns professores, as notas baixas que validam uma situação de não obtenção de reconhecimento da sua competência pelo professor e pelos amigos, a sofisticação dos cálculos, as difículdades de estudar sozinho, a dificuldade de se colocar como aquele que não sabe, a pressão da família, etc., são elementos que colocam o aluno numa situação em que o conhecimento científico, que deveria ser a garantia para ser professor, parece estar escapando de suas mãos. Como lutar 
pelo conhecimento em condições tão pouco promissoras? Como lutar, se o aluno não tem mais reconhecimento, amor, quando não vai buscar ajuda? Que álibis ele poderia estabelecer para conseguir tirar o excesso de tensão e ainda encontrar uma saída para superar estas dificuldades aparentemente instransponíveis?

É possível que a perda do controle sobre o atendimento das demandas na busca da aquisição do conhecimento científico possa realmente fazer com que esse aluno desista de ser professor, principalmente se esse desejo de conhecer Física estiver vinculado ao desejo de ser professor de Física, no caso dos cursos de licenciatura. Acreditamos nessa possibilidade de vinculação, já que, nesse caso, se o aluno desiste do seu desejo de conhecer Física, se ele não suporta o que vem junto com a possibilidade de obtenção de conhecimento, evidentemente seu desejo de ser professor dessa disciplina parece morrer também.

A possibilidade de satisfação descrita na história do aluno, não está sob controle, já que, nesse caso, há a rejeição da família pelo conhecimento que ele deseja; as dificuldades que lhe foram postas sobre a impossibilidade de vencer e se tornar professor de Física; a falta de amor de alguns professores que têm os seus alunos prediletos; e o medo que percebemos no seu discurso de perder o amigo com quem ele se identifica. Parece-nos que ele ainda está preso no curso pelo amor que tem por esse amigo e pelo desafio de vencer as más predições. O que ele espera é que, ao final de todo esse sofrimento, haja algum tipo de reconhecimento, conseqüentemente amor e, portanto, a chance de começar a pagar a dívida simbólica com o conhecimento, atuando como professor.

Entretanto, no nosso trabalho, o movimento é outro, já que o professor é detentor do conhecimento científico e se coloca na posição daquele que tudo sabe. Evidentemente que uma desistência também poderá ocorrer, mas a dificuldade será muito maior, pois o sujeito, segundo a nossa análise, entrará em contato com uma situação ideal que possibilita o atendimento de suas demandas mais subjetivas. Quanto à possibilidade de o professor desistir da profissão poderemos, e é o que faremos nessas considerações finais, estabelecer várias hipóteses. 


\subsection{ANALOGIA COM O MODELO DE LAKATOS}

A organização dos dados, utilizando o referencial psicanalítico, articulado à imagem do modelo de Lakatos, permitiu a elaboração de um novo modelo interpretativo em que aparecem as demandas imaginárias que o professor fez questão que estivessem presentes no seu discurso. Nesse modelo, os elementos que em nossa inferência justificam a manutenção da docência - demanda de amor, dívida simbólica e reedição da situação parental constituem o núcleo firme, protegido por um cinturão formado por hipóteses, recursos e estratégias que se articulam em justificações irrestritas, situações de gozo, que o sujeito cria para evitar que qualquer elemento externo possa atingir o núcleo.

Utilizando esse modelo, pudemos considerar que essas demandas imaginárias encontraram uma possibilidade de satisfação a partir da premissa de que há uma dívida do sujeito com o conhecimento científico. O professor acredita que, ao deter esse conhecimento, está legitimado a se colocar na posição de um sujeito de suposto saber, um lugar que lhe promete completude. Assim, as demandas estão atravessadas pelo conhecimento científico, porque quando falamos em dívida simbólica, falamos também em dívida com o conhecimento científico, a tentativa de deixar herdeiros deste; em reedição da situação parental, falamos também dos cuidados que se deve ter com o aluno e com a adequação que deve ser feita na administração do conhecimento científico para deixarmos herdeiros desse conhecimento; em demanda de amor, falamos também do reconhecimento amoroso que o domínio do conhecimento científico pode proporcionar quando nos mostramos competentes e com domínio sobre ele; em gozo, podemos exemplificar com situações da sala de aula que possibilita ao professor novas formas de gozo, quando é solicitado a explicar de inúmeras maneiras e inúmeras vezes os mesmos conteúdos científicos.

Então, quando o professor não consegue atingir ou satisfazer as condições impostas pelo núcleo firme, que são as demandas que ele faz aos outros, ele lança mão do cinturão protetor, com todas as metodologias, recursos e estratégias didáticas, considerações e justificativas que conseguir racionalizar, com o intuito de proteger o núcleo firme. A proteção ao núcleo firme, aparentemente, faz com que o professor se mantenha firme em suas crenças fundamentais. Porque, para o professor renunciar ao que, imaginariamente, está no núcleo firme, nos parece significar o mesmo que desistir da profissão. Portanto, ele não pode renunciar às suas demandas, nem à sala de aula e tampouco ao aluno, porque aí, no cenário sala de aula e alunos está a configuração ideal para vislumbrar uma promessa de completude. 
As explicações ad hoc ${ }^{33}$ são as que tentam manter a integridade do núcleo e, nelas, encontramos vários elementos responsáveis pela impossibilidade de sucesso do professor como o tempo, o dinheiro, o aluno, as exigências da instituição, a violência na escola, a repetência, a evasão escolar, etc..

Mesmo assim, com todos os problemas para os quais já chamamos a atenção na introdução desse trabalho, o professor mostra uma fé fundamental no paradigma que é o núcleo firme. A fé fundamental é de que o gozo vai ajudar a resolver as ameaças aos elementos do núcleo, ou seja, se houver algum problema que o coloque em risco, surgirão tentativas de ajustes com as explicações ad hoc, para poder contorná-lo.

\subsection{ALGUMAS HIPÓTESES}

Baseados nas conclusões a que demos voz até aqui, nos propusemos a pensar em outros desdobramentos que a nossa análise e referencial pudessem permitir. Para isso reunimos quatro situações hipotéticas, sobre a permanência na situação docente e as analisamos.

Uma primeira situação interessante que poderia ocorrer seria quando o núcleo firme fosse atacado realmente em alguns dos seus elementos: demanda de amor, divida simbólica e reedição da situação parental. O que poderia acontecer?

O professor passaria a viver uma situação conflituosa que o desestabilizaria e que aparentemente o paralisaria, fazendo com que não conseguisse dar conta satisfatoriamente das suas funções e se perdesse em justificativas. Na realidade essa não-ação, essa paralisação, nos parece um mecanismo de sobrevivência da profissão, que age temporariamente até que o professor se dê conta de que ainda existem, no núcleo firme, elementos que têm uma promessa de completude e, portanto, devem ser protegidos, o que faz com que o professor volte a se mobilizar.

O professor faz essas demandas para cada aluno em particular, portanto sempre haverão outros alunos na sala de aula que estarão dando a ele a possibilidade de retomar o

\footnotetext{
33 Ad hoc- Hipótese ad hoc ocorre na ciência quando aparece alguma anomalia que conflita com a teoria já estabelecida, que não possui um mecanismo explicativo essencial. Propõe-se uma hipótese ad hoc (somente para dar conta da anomalia) para explicar o que a teoria não consegue explicar.
} 
ilusório controle da situação, ou seja, o atendimento ideal de todas as demandas, a completude.

Entretanto se a rejeição dos alunos pelo professor for unânime, a situação poderia ficar, aparentemente, sem controle e uma possibilidade de reversão poderia acontecer somente se houvesse apoio da instituição de ensino, ou seja, se a instituição reafirmasse, para os pais e para o professor, a crença no sucesso de seu método de trabalho. Fazendo isso, a instituição estaria dizendo para o professor 'nós confiamos nos seu conhecimento científico e nós podemos suprir parte da sua demanda de amor', o que poderia possibilitar a permanência do professor.

Uma segunda situação a ser considerada seria quando um aluno, por circunstâncias diversas, não consegue causar no educador um desejo de investimento, não consegue fazer o professor ver nele a possibilidade de obtenção de satisfação das demandas. Sabemos que essa satisfação, apesar de inconsciente, é vital porque são essas demandas que possibilitam ao professor a crença imaginária de que se tornará pleno. Portanto, quando o aluno não responde desse lugar ideal, lugar onde o aluno é tomado como perfeito, como se o professor tivesse sido esse ideal de aluno no passado, está respondendo de um outro lugar que acaba remetendo o professor às experiências de gozo, fazendo surgir queixas, muito comuns hoje em dia nas instituições de ensino, que são dirigidas aos alunos, pais, pares e instituição.

Uma terceira situação hipotética diz respeito ao fato de o professor colocar o conhecimento científico que está relacionado com o pagamento da dívida simbólica, e que o habilita a exercer a sua profissão, acima de todas as outras demandas, ou seja, acredita que só a proteção do conhecimento científico satisfaz a sua falta. Sabemos que ele encontrará problemas, porque o não investimento na demanda de amor, e na reedição parental, pode fazer com que seja um professor que distancia cada vez mais os conteúdos científicos do aluno, na medida em que não tem interesse em cuidar para que os conteúdos sejam acessíveis, ou moldáveis, para que o aluno possa alcançá-los; logo, não faz reedição e acredita que vai ser amado apenas pelo conhecimento que detém. Entretanto, apesar dos problemas, ele tem chance de permanecer em sala de aula porque estará pagando a dívida simbólica, enquanto permanece em situação de gozo em relação às outras demandas.

Finalmente, uma quarta situação hipotética poderia ser quando o gozo da queixa toma conta da profissão, ou seja, torna-se autônomo e não protege a crença na plenitude. Nesse caso o professor abandonou sua profissão, desistiu, mesmo que, de fato, continue dando aula. Essa situação é aquela em que, segundo Mrech (1999), o professor atua por inércia, está em 
sala de aula, mas está ausente dela. Não investe mais na relação com o aluno mesmo que ocorram mudanças na situação que, até então, estava instalada em sala de aula.

Nesse caso, de gozo autônomo, o professor poderia ficar preso nessa situação e continuar em sala de aula apesar de não investir na proteção das demandas. Poderiam acontecer alguns movimentos: em algum momento, um elemento novo poderia mobilizá-lo a fazer um reinvestimento na proteção das demandas; ou poderia se deslocar para uma nova situação em outra sala de aula, provavelmente, em outra instituição, onde pudesse renovar a sua crença de proteção no núcleo; a desistência, possivelmente, ocorreria quando todas as tentativas fossem frustradas e o colocassem em situação de abandonar a docência e investir em uma nova profisssão.

Exemplificando essa hipótese em particular, nos valemos de trechos de uma situação real, vivida em sala de aula, que constituem o caso da $5^{\mathrm{a}} \mathrm{w}$, uma turma de aceleração ${ }^{34}$, que foram extraídos e adaptados da dissertação de mestrado de Batista (2002)

A $5^{\text {a }} \mathrm{W}$ é uma das turmas de ensino fundamental de uma escola pública da periferia da cidade de São Paulo. De acordo com depoimentos dos professores e da direção dessa escola a grande maioria dos alunos dessa turma representava o que pode existir de pior em uma escola. Eles foram retratados como indisciplinados, desinteressados, burros, preguiçosos, faltosos e envolvidos com más companhias do bairro. Alguns professores tinham uma relação muito tensa com a sala e já tinham perdido totalmente o controle da situação. A professora de português disse numa ocasião: "Eu não vou passar vídeo, pois essa é uma sala de cavalos e a diretora proibiu. Nenhum aluno vai ser dispensado antes do dia 17 e alguns não irão passar de ano". (grifo nosso)

Alguns professores encaravam dar aula naquela sala como um pesadelo; temiam por sua integridade moral e física, tinham dificuldades em transmitir o que queriam e estabelecer uma rotina de trabalho. Muitos pareciam derrotados pelos alunos e pela sua capacidade em controlar o espaço e o tempo escolar. A situação só parecia melhorar com a ausência dos jovens considerados problemáticos. Quando eles faltavam ou ficavam temporadas sem aparecer, tudo parecia ficar mais calmo. E era essa aparente calma que explicava porque muitos professores não faziam nada para evitar a falta dos alunos. Mas, assim que esses alunos resolviam retomar à cena, tomavam-se senhores da situação. Para esses alunos, a escola parecia cumprir a função de um palco, onde eles representavam um papel.[...] Assim, todo trabalho foi definido a priori como inútil, como parece demonstrar o depoimento da professora de Inglês: "Não adianta nada. Você tenta, tenta, mas eles não querem aprender. Não entendem que poderia ser útil aprender inglês. Eles não pensam no futuro. Também muitos vão ser bandidos ou vão trabalhar na feira". (grifo nosso) [...] Os professores, no entanto, parecem não ter desenvolvido nenhum trabalho especial na $5^{\mathrm{a}} \mathrm{W}$. Os únicos que sempre lembraram que aquela era uma sala de aceleração foram os alunos, principalmente, as meninas. Alguns nutriam esperanças de poder avançar no percurso escolar e assim colocar um fim na vergonha que sentiam de ainda

\footnotetext{
${ }^{34}$ Turma de aceleração - iniciativa para proporcionar aos alunos repetentes a possibilidade de recuperar os anos perdidos. O programa consiste em unir, numa mesma sala, estudantes reprovados mais de uma vez.
} 
estarem na $5^{\circ}$ série, como ilustra o depoimento de uma das alunas."Eu tenho vergonha de tá na $5^{a}$ série, sou muito grande já. Eu queria era tá na $8 \mathrm{a}$. Eu não conto prá ninguém não que eu ainda tô na $5^{\text {a'”. (grifo nosso) }}$

[...] "O que meu filho mais gostava na escola era fazer o professor de bobo, sempre chegava em casa contando o que tinha feito e quem tinha enrolado. Ele gostava de brincar, era moleque". (mãe de um ex-aluno).(grifo nosso)

[...] Tudo começava e terminava nos próprios alunos e não cabia aos professores modificar essa situação. As condições estavam dadas, só lhes restava suportar e torcer para que o tempo passasse o mais rápido possível. "Ter que subir, ficar agüentando aluno... Não estou com a mínima vontade. Bem que o tempo poderia passar bem rapidinho. (professora do período vespertino)".(grifo nosso)

Aula de Português - [...] Kadu empresta a sua caneta para o colega. A caneta estoura e ele diz que vai espancar o colega caso não ganhe uma caneta nova. Joelma dá uma de suas canetas para Kadu para colocar um ponto final na questão. A professora entrega folhas para que os alunos façam uma redação com o tema: "Oração do Filho". Enquanto isso, sorrateiramente, Renan sai da sala. Alcides pede para fazer a redação em casa. Renan fica na porta espiando a professora. Joelma permanece alheia, parece que seus pensamentos estão longe. Kadu diz que vai para a favela de Diadema porque lá ele vai aprender alguma coisa: roubar. Um aluno de outra sala entra e fica andando pela classe. Alguns meninos brigam, parece não existir uma diferenciação nítida entre comportamento de rua e comportamento de escola. O sinal bate e os alunos vão embora correndo! A pesquisadora passa pela mesa da professora e percebe que ela estava lendo uma revista." (transcrição do caderno de campo, 08 de setembro de 1999).Muitos dos alunos apresentavam sérias dificuldades de escrita. Os exemplos abaixo, retirados dos cadernos de alguns alunos, ilustram essa afirmação:

Era um grande adirta, não sor interpretava mais também tançava muito bem. Chegou, soriu, inte tanto não roer disse nada. A tarte está boa para um paseio, poriço já estou mer dispidindo. A mãe preocupada colocol a mão na cabeça do filho e axo fill. (Caderno do aluno Fernando, ditado do dia 27 de agosto). (grifo nosso)

A manhã acondeçara a festa no Pacaibuns. comcuzão -apretizagem acomboiamento (Caderno do aluno Alexandre, ditado do dia 27 de agosto) (grifo nosso)

Este fragmento do trabalho de Batista exemplifica, muito bem, a desistência do professor da sua profissão ou, ao menos, os impasses que ocorrem na desistência da proteção do núcleo firme. Não sabemos se essa desistência foi local e temporária ou se os impasses permaneceram de forma definitiva na vida desses professores. De qualquer forma, na situação descrita, os professores desistiram de sua profissão, não tinham nenhum controle sobre os alunos e nem sobre o ensino e se justificavam dizendo que eles eram indisciplinados, burros, preguiçosos, etc. Percebemos que o professor, apesar do conhecimento científico, nesse caso, desistiu de deixar herdeiros desse conhecimento, não queria pagar a dívida e não queria amor desses alunos. Estava preso em considerações de gozo que eram reforçadas por todos os pares. E nessa situação de gozo, não havia nenhuma argumentação que possibilitasse algum movimento. Não partiam em busca daqueles alunos que poderiam lhes fornecer os primeiros 
movimentos de alguma aposta de satisfação imaginária como, por exemplo, aquela aluna que se sentia envergonhada e não queria que os outros soubessem que ela ainda estava na quinta série. Em vez disso, todos concordavam, inclusive a diretora, que os alunos eram uns 'cavalos' e a punição vinha em forma de ameaças como: não passar vídeo ou ser reprovado. Os professores se sentiam reféns da situação porque se intimidavam e não conseguiam estabelecer laço com os alunos-problema, nem com os outros. A maior prova de desistência foi a atitude da professora de Português, que demonstrava um alheamento total sobre o que acontecia na sua sala de aula: apenas passava a tarefa, se isolava do entorno e começava a ler uma revista. Será que, em algum momento, esses professores fizeram alguma aposta nesses alunos? Será que eles insistiram o suficiente? Porque desistiram? Cada um tem uma experiência pessoal que gerou a desistência, ou foram na 'onda' das informações dos outros pares? Como poderíamos interpretar a situação em que se colocam, de estarem agüentando aluno, sendo que, sem os alunos, não estariam habilitados a ser professores?

No caso citado, a proteção das demandas não se efetivava porque, no cinturão, estavam milhares de justificativas, mas que não se sofisticaram no sentido de atacar os problemas, de responder às situações difíceis, de procurar uma elaboração dentro das variáveis intelectuais, morais e até materiais que ali estavam. Os professores pareciam incapazes de promover uma aposta na obtenção de satisfação de alguma demanda. Além de o impasse envolver os professores, os alunos e a direção da escola, também os pais não pareciam interessados em exigir mudanças; não viam como problema as atitudes dos filhos em dificultar o trabalho dos professores. Acreditamos que, nesse caso, somente uma mudança de escola, ou de instituição em que lecionam, poderia se tornar o ponto de partida para reavivar as esperanças de completude de alguns dos professores e impedir que seu abandono da profissão se torne definitivo.

\subsection{AMPLIAÇÃO DA ANALOGIA COM O MODELO DE LAKATOS: A METODOLOGIA DOS PROGRAMAS DE PESQUISA CIENTÍFICA E O MODELO DE PRODUÇÃO E SUSTENTAÇÃO DA DOCÊNCIA.}

Durante a organização dos dados, a estrutura explicativa que tínhamos estabelecido nos remeteu a uma estrutura utilizada em outro campo, a da História e Filosofia da Ciência. Então, justamente para estabelecer os limites do modelo de Lakatos (1979), do qual até agora tínhamos utilizado apenas a imagem na explicitação da manutenção dos professores na sua 
profissão, fizemos uma analogia mais detalhada dessas possibilidades, utilizando também as relações teóricas estabelecidas por ele. (Veja os diagramas B. Modelo de Lakatos da produção do conhecimento científico; e C. Modelo da produção e sustentação docente).

Nesse estabelecimento, nos pautamos no trabalho de Silveira (1996), que, utilizando a teoria de Lakatos, nos diz que "A avaliação objetiva do crescimento do conhecimento científico deve ser realizada em termos de mudanças, progressivas ou regressivas, para séries de teorias científicas dentro de um 'programa de pesquisa'”.

O nosso primeiro contato com esse modelo ocorreu numa disciplina de Filosofia da Ciência, o que possibilitou que ele estivesse disponível ao nosso raciocínio, quando os dados começaram a apontar para elementos que nos pareceram se constituir como o cerne da ligação do professor com sua profissão. Elementos que, aparentemente, necessitavam manter-se íntegros, já que a proteção deles parecia vital para a permanência na profissão. Então, quase que naturalmente, devido à sua própria configuração, o modelo de Lakatos nos ajudou a organizar os dados e levantar hipóteses sobre a validade dessa organização.

Silveira (1996) reitera que "um programa de pesquisa pode ser caracterizado por seu 'núcleo firme ${ }^{35}$ ': teoria ou conjunção de hipóteses contra a qual não é aplicada a 'retransmissão da falsidade"'.

Levando-se em conta o modelo, na produção do conhecimento científico, podemos considerar que estão no núcleo firme as diretrizes, que são, convencionalmente, aceitas pela ciência e que deverão ser protegidas. Agora, pensando na produção e sustentação da profissão docente, podemos considerar que, no núcleo firme, estão as diretrizes que se constituem nas demandas que organizam a profissão, na medida em que são requisitos que podemos considerar subjetivamente aceitos e, portanto irrefutáveis, por aqueles que estão na profissão. Permanecem nela, segundo a análise que já estabelecemos, porque querem amor, reconhecimento, deixar herdeiros e que o outro contraia a mesma dívida simbólica, entre outras coisas. Esses elementos são irrefutáveis porque dizem respeito a demandas que têm origem na sua própria constituição como sujeito.

\footnotetext{
${ }^{35}$ Núcleo firme-"O núcleo firme é 'convencionalmente' aceito (e, portanto, 'irrefutável' por decisão provisória)" (Lakatos, 1983; p. 116).
} 


\section{B. Modelo de Lakatos da produção do conhecimento científico}

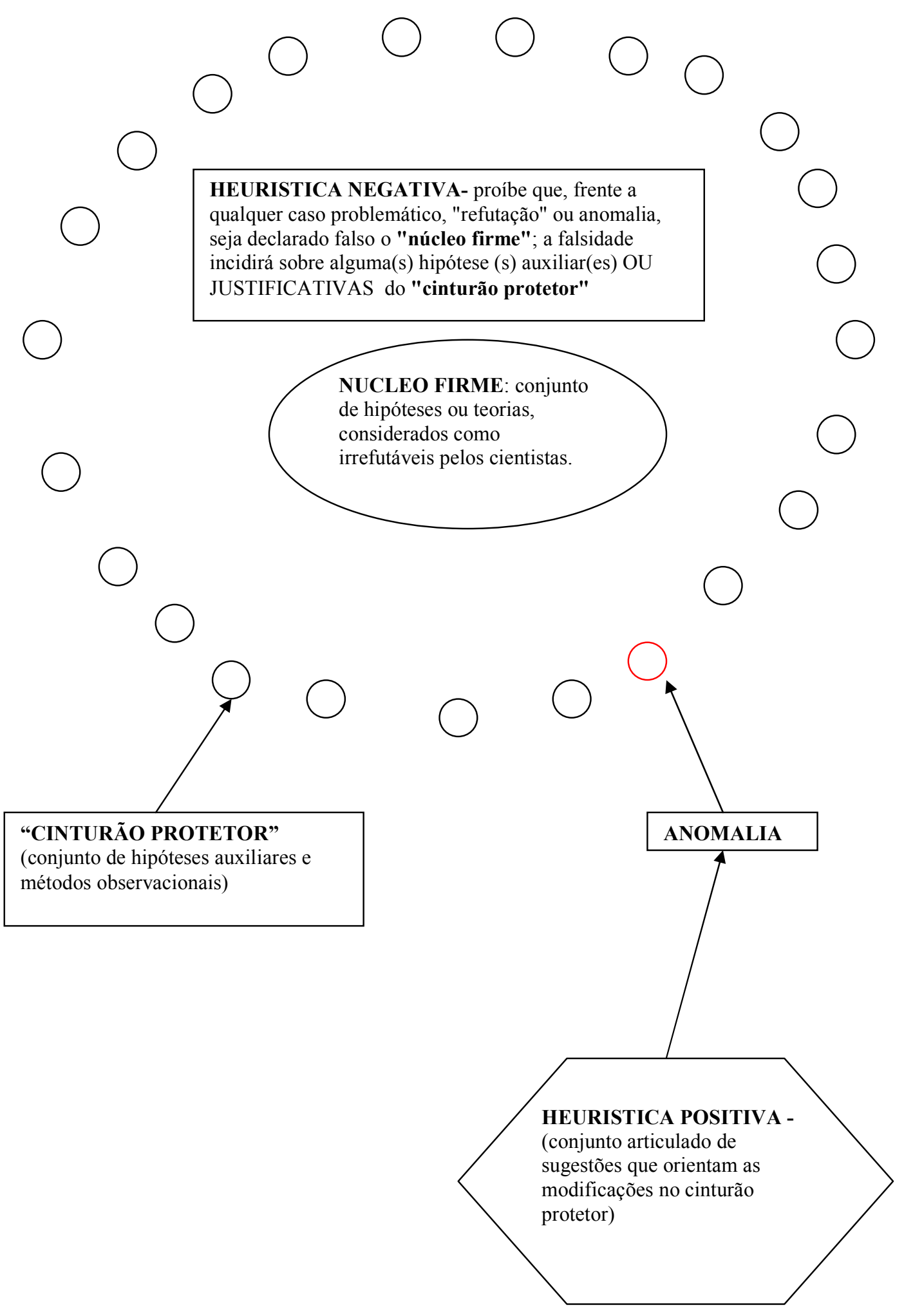




\section{Modelo da produção e sustentação docente}

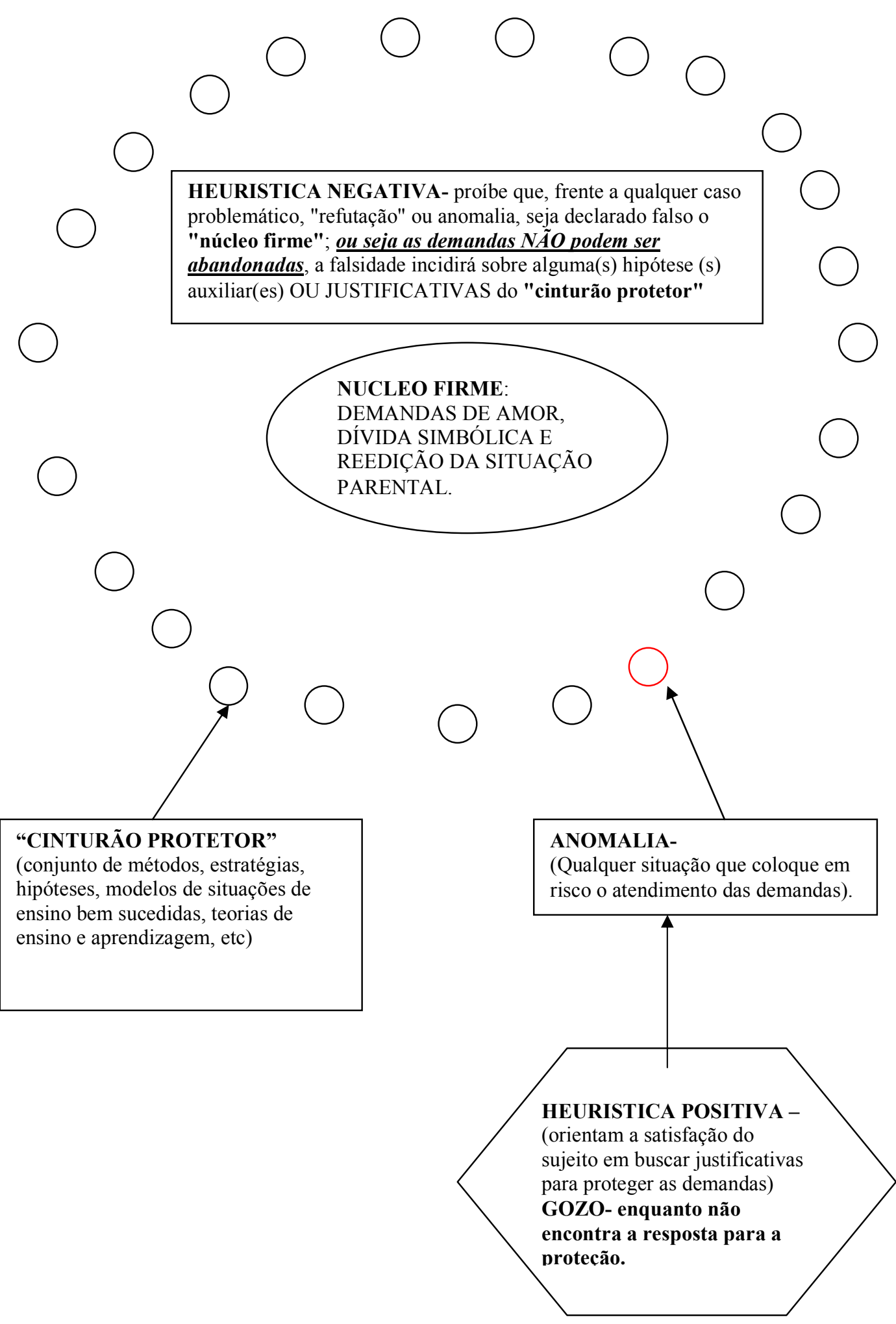


Na produção do conhecimento cientifico:

"o "cinturão protetor" é constituído por hipóteses e teorias auxiliares "sobre cuja base se estabelecem as condições iniciais" (LAKATOS, 1989; p.230) - e também pelos métodos observacionais. Ele protege o "núcleo firme", sendo constantemente modificado, expandido, complicado". (SILVEIRA, 1996)

$\mathrm{Na}$ produção e sustentação da profissão docente consideramos que o conjunto de hipóteses e teorias, que são dadas a partir das condições iniciais, ou seja, a partir da necessidade de proteção dos elementos que estão no núcleo firme, pertence ao cinturão protetor sendo que podem ser, e são, constantemente modificadas e sofisticadas.

Como se constituiu, então, esse cinturão protetor no nosso modelo?

Para manter as demandas protegidas, encontramos, no cinturão, uma infinidade de teorias que lançam a possibilidade imaginária de que a sala de aula tenha sucesso e, assim possibilite a obtenção de reconhecimento. Temos, então, à disposição, constituindo o cinturão: metodologias, recursos e estratégias, hipóteses, modelos de situações de ensino bem sucedidas, teorias de aprendizagem, teorias psicológicas, etc.

Por que optamos aqui pela denominação produção e sustentação docente?

Porque consideramos que o modelo possibilita o entendimento de que a dinâmica das relações que se estabelecem para proteção do núcleo firme, os ajustes que devem ser feitos, as hipóteses sobre os eventos passados e a possibilidade dessas considerações e justificações, fortalecem a situação da docência a ponto de o professor sentir-se seguro para prever ou criar novas situações que possam alcançar bons resultados de aprendizagem. Inferimos que, com esse exercício, além de estar se produzindo como professor, ainda está garantindo a sua permanência, porque há o aumento de possibilidades de proteção das suas demandas.

O que Lakatos afirma é que a "heurística negativa" do programa proíbe que, frente a qualquer caso problemático, "refutação" ou anomalia, seja declarado falso o "núcleo firme"; a falsidade incidirá sobre alguma(s) hipótese (s) auxiliar(es) do "cinturão protetor".(SILVEIRA, 1996)

A heurística ${ }^{36}$ negativa aplicada à produção e sustentação da profissão proíbe, da mesma forma, que o conteúdo do núcleo firme seja questionado ou desestabilizado; que é constituído de demandas, que são primordiais para a manutenção na docência e que não devem sofrer nenhum abalo. Esses abalos, ou falsidades, deverão ser amortecidos e justificados no cinturão protetor por hipóteses que lá estejam, ou por uma sofisticação, ou

\footnotetext{
${ }^{36}$ Heurística- diz-se da hipótese de trabalho que, mesmo não se sabendo da sua veracidade, adotamos provisoriamente como diretriz para investigação dos fatos. É uma regra que limita a busca por soluções em domínios que são difíceis e pouco compreendidos. Quando não se conhece o melhor caminho para resolver um problema, podemos definir uma função heurística que pode levar a essa solução. É a dinâmica, como você tem que se conduzir (RUSSEL, S. NORVIG, P. Inteligência Artificial: Um enfoque moderno, São Paulo, Campus, 2004).
} 
criação de uma nova hipótese, que possa ser mais eficaz na proteção das demandas que constituem o núcleo firme.

Na produção de conhecimento científico.

Quando os cientistas se deparam com algum fato incompatível com as previsões teóricas - uma "refutação" ou anomalia - a "heurística positiva" orienta, parcialmente, as modificações que devem ser feitas no "cinturão protetor" para as superar."A heurística positiva consiste num conjunto parcialmente articulado de sugestões ou palpites sobre como mudar e desenvolver as 'variantes refutáveis 'do programa de pesquisa, e sobre como modificar e sofisticar o cinto de proteção ' refutável ' " (Lakatos,1979; p. 165).Como os programas de pesquisa têm desde o início um "oceano de anomalias", a "heurística positiva" impede que os cientistas se confundam, indicando caminhos que poderão, lentamente, explicá-las e transformá-las em corroborações".(SILVEIRA, 1996).

Pensando na produção e sustentação da profíssão docente, a heurística positiva, na nossa interpretação, tem relação com o gozo, porque ela orienta a satisfação do sujeito em buscar infinitas justificativas, criando um discurso articulado que seja capaz de modificar e sofisticar o cinturão de proteção. Ou seja, quando tudo o que está disponível no cinturão protetor e que tem na base o atendimento das demandas, quando uma dessas situações que deveriam se mostrar bem sucedidas falham nessa proteção, há o aparecimento de uma 'anomalia', a qual permite o surgimento de situações de gozo, que têm funcionamento similar ao da heurística positiva e, portanto, não permite ataque às demandas, criando teorias, hipóteses, articulando elementos do cinturão, sofisticando-os de tal forma que possam explicar os fatos ocorridos, fazer previsões para proteção de situações de risco e, assim, digerindo as anomalias.

A avaliação dos programas de pesquisa envolve regras que os caracterizam como "progressivos" ou "regressivos". Um programa é "teoricamente progressivo" quando cada modificação no "cinturão protetor" leva a novas e inesperadas predições ou retrodições ${ }^{37}$. [...] Sempre é possível, através de convenientes ajustes no "cinturão protetor", explicar qualquer anomalia. Estes ajustes são "ad-hoc" e o programa está "regredindo" ou "degenerando" quando eles apenas explicam os fatos que os motivaram, não prevendo nenhum fato novo, ou, se prevendo fatos novos, nenhum é corroborado. Um programa está "regredindo" ou "degenerando" se "seu crescimento teórico se atrasa com relação ao seu crescimento empírico; isto é, se somente oferece explicações post-hoc de descobertas casuais ou de fatos antecipados e descobertos por um programa rival" (Lakatos, 1983; p. 117). (SILVEIRA, 1996)

\footnotetext{
${ }^{37}$ Uma retrodição é a explicação de um fato já conhecido. Uma predição é a antecipação de um fato ainda não observado. SILVEIRA, F. L. A metodologia dos programas de pesquisa: Caderno Catarinense de Ensino de Física, v.13, n.3, dezembro 1996, p. 219-230.
} 
A produção da profissão docente ganha status de progressiva, se todas as justificativas que são elaboradas no cinturão protetor tornam-se capazes de explicar situações que já ocorreram em sala, e ainda são frutíferas, no sentido de dar ao professor a segurança ilusória de que tem poder de resolver qualquer conflito e, ainda, atender as demandas. Quanto mais confiança na elaboração de explicações, para fatos já ocorridos e nas previsões sobre a manutenção e proteção das demandas, ou seja, quando mais ele sofistica o cinturão sem recorrer aos ajustes ad hoc para explicar as anomalias, mais o professor se produz ou se constitui como tal e, portanto, existe maior chance de sua manutenção na docência.

Entretanto, quando o professor apenas consegue justificar os desajustes que estão ocorrendo, procurando álibis para a sua atuação, mas não tem segurança para fazer ajustes na sua atuação, sua condição torna-se regressiva. Ou seja, não consegue a partir da explicação das anomalias, ganhar forças para empreender hipóteses mais sofisticadas e previsões de resultados da sua relação com a profissão, precisando recorrer muito mais vezes a hipóteses ad hoc. Nessa situação de insegurança e de falta da possibilidade de proteção das demandas, a profissão docente é colocada em situação de degeneração, na medida em que o professor não encontra chão seguro para avançar em relação à sua crença de atendimento das suas demandas. E, nessa situação, o cinturão estará inflado com hipóteses ad hoc em excesso que não conseguem proteger o núcleo, ou seja, a heurística negativa será maior que a positiva.

Resumindo e organizando melhor as idéias, segundo Lakatos (1979), as teorias estão protegidas em um núcleo firme, constituído pelas proposições fundamentais do programa, que dão origem a inúmeros problemas e são consideradas irrefutáveis. A heurística positiva do programa proporciona meios para resolver esses problemas e seu cinturão protetor de hipóteses auxiliares protege o núcleo firme. Quando as modificações teóricas que ocorrem no cinturão conduzem a previsões bem sucedidas de fatos novos, o programa é progressivo, mas, se essas modificações forem apenas manobras ad hoc, então, o programa torna-se degenerativo. A ciência procura aumentar sempre o conteúdo empírico e preditivo de suas teorias, mas o aumento desse conteúdo não deve ser apenas ad hoc.

As hipóteses ad hoc surgem quando não há condições de explicar os fatos com o que está disponível no cinturão protetor. Através da heurística positiva, as justificativas para explicar a teoria que está apresentando problemas são acomodadas no cinturão protetor, ou seja, todas as novas hipóteses e justificativas que forem geradas a partir daí, estarão disponíveis no cinturão podendo surgir neste contexto, do cinturão, novas hipóteses. 
A seguir reunimos, em um quadro explicativo, as principais idéias dos programas de pesquisa, para ilustrar com maior clareza as relações do modelo de Lakatos (quadro D. Programas de Pesquisa (PP) Lakatos).

\begin{tabular}{|l}
\hline \multicolumn{1}{|c||}{ D. Programas de Pesquisa (PP) Lakatos } \\
Mecanismo de proteção \\
Manter a todo custo o núcleo firme \\
Usar de hipóteses auxiliares para absorver "ataques" ao núcleo firme. \\
Mecanismo de adaptação \\
Desviar ataques para as hipóteses auxiliares, se for necessário elas devem ser alteradas. \\
PP progressivo \\
Mudanças “explicam” refutações e/ou geram novas predições \\
PP degenerativo \\
Caso contrário, as mudanças são ad hoc.
\end{tabular}




\subsection{RELACIONANDO O MODELO DA PRODUÇÃO E SUSTENTAÇÃO DOCENTE COM O REAL, SIMBÓLICO E IMAGINÁRIO.}

Utilizando os três registros psicanalíticos: real, simbólico e imaginário, e o modelo dos nós borromeanos, que, segundo Lacan (1972), estão entrelaçados de tal forma que, rompendo um deles, os outros dois também se separam, tentamos fazer uma adaptação ao modelo de Lakatos e tecemos algumas considerações sobre como cada registro aparece ligado aos outros dois. (ver diagrama E. o real, o simbólico e o imaginário).

Considerando a reedição da situação parental, destacamos que, em nossa interpretação, ela pode ser imaginária se pensarmos nos cuidados que os pais tiveram conosco e, por vezes, simbólica, já que aprendemos a reproduzir estes cuidados - ir à missa, comer corretamente, tomar banho, etc. Pensando na situação da sala de aula, o aluno devolve, ou pode devolver para o professor, algo da ordem do real porque a figura do professor, assim como a dos pais, é colocada como continente, que recebe, por parte do aluno, todas as necessidades, expectativas e angústias em relação ao conhecimento e, às vezes, em relação à sua própria pessoa. $\mathrm{O}$ que significa que, na reedição parental, encontramos os três registros, pois existe uma solidariedade constitutiva entre eles.

Portanto, enquanto o gozo da queixa serve para aliviar a tensão sobre os problemas, existe também o gozo de ser continente, de o aluno depositar, no professor, os desejos, angústias, amor, etc. Então, existe o gozo dentro e o gozo fora. O gozo dentro, que estaria no núcleo firme e fortaleceria a relação do amor, que incluiria também fazer reedição de situações vividas; e o gozo fora, que teria relação com o real e que, devido à heurística positiva, reajustaria o cinturão protetor. Portanto, o gozo fora tem relação com o cinturão protetor quando está sofrendo reajustes. O que ocorre é que esses registros: real, simbólico e imaginário, estão ligados, mas, em determinados momentos, um prevalece sobre os outros.

Fizemos uma tentativa de situar esses registros prevalentes, no modelo que estamos utilizando, relacionando-os com a demanda de amor, dívida simbólica, reedição parental e gozo. Como pudemos observar, no núcleo firme estão a dívida simbólica, que está no registro do simbólico; a demanda de amor que pertence ao registro do imaginário e a reedição parental, que optamos por situar, nesse esquema no registro do imaginário, embora já tenhamos tecido considerações sobre o fato de que cada um desses elementos pode vir a ocupar qualquer um dos três registros. Finalmente, situamos o gozo no cinturão protetor, já que as anomalias, podem ser vistas ou pensadas como da ordem do real devido à situação de desamparo que o professor é colocado quando vê em risco suas demandas fundamentais. 
E. o real, o simbólico e o imaginário.

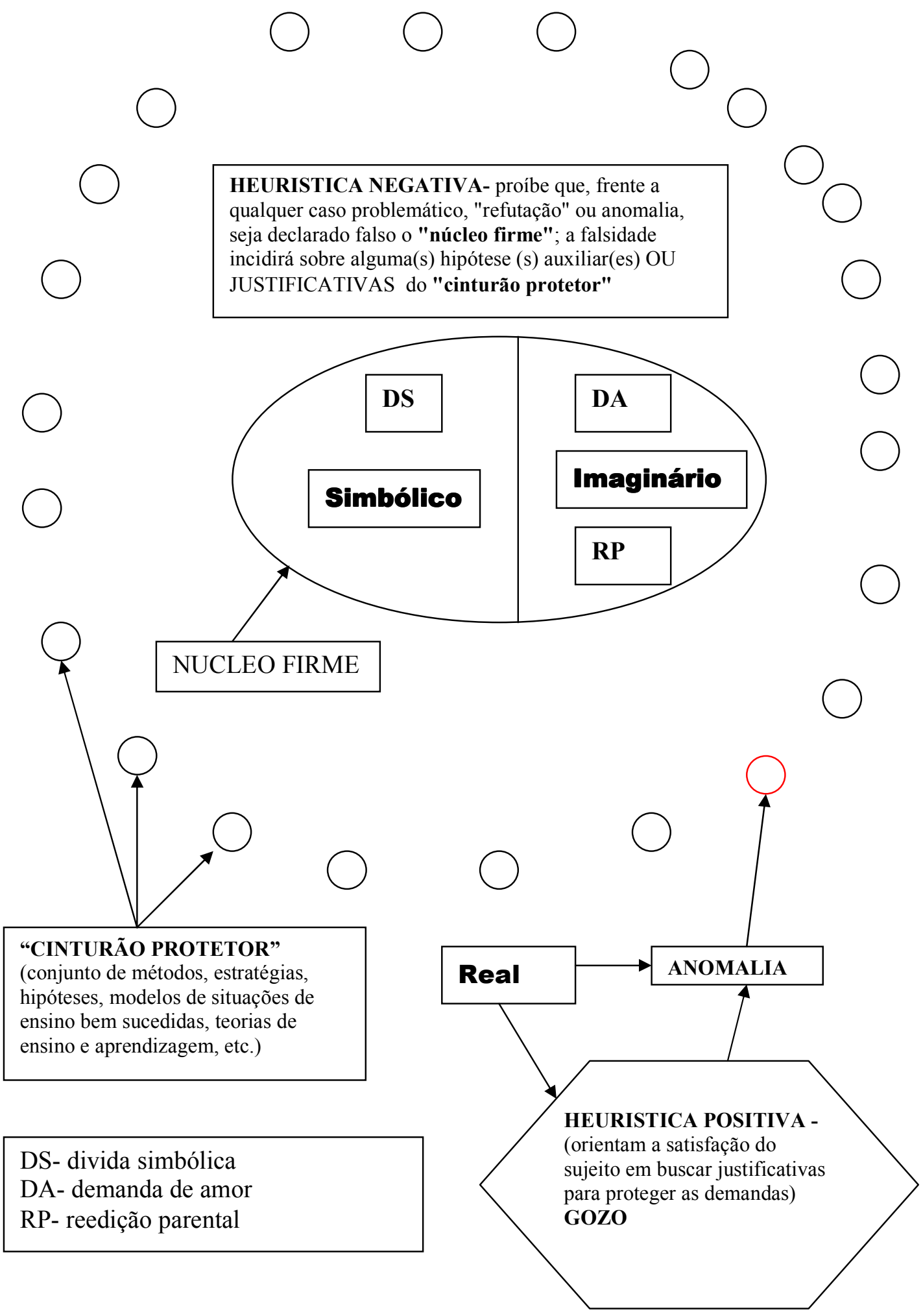




\subsection{ORGANIZAÇÃO DO MODELO NUMA SITUAÇÃO DE ENSINO}

Podemos observar melhor o movimento da constituição e manutenção docente, utilizando o modelo de produção e sustentação da profissão, que elaboramos, aplicado numa situação genérica de ensino. (ver F. Diagrama - aplicação na situação de ensino).

F. Diagrama - aplicação na situação de ensino

\section{SITUAÇÃO DE ENSINO}

\section{CINTURÃO PROTETOR}

Metodologias, recursos, estratégias ensino, teorias de aprendizagem, situações bem sucedidas, etc.

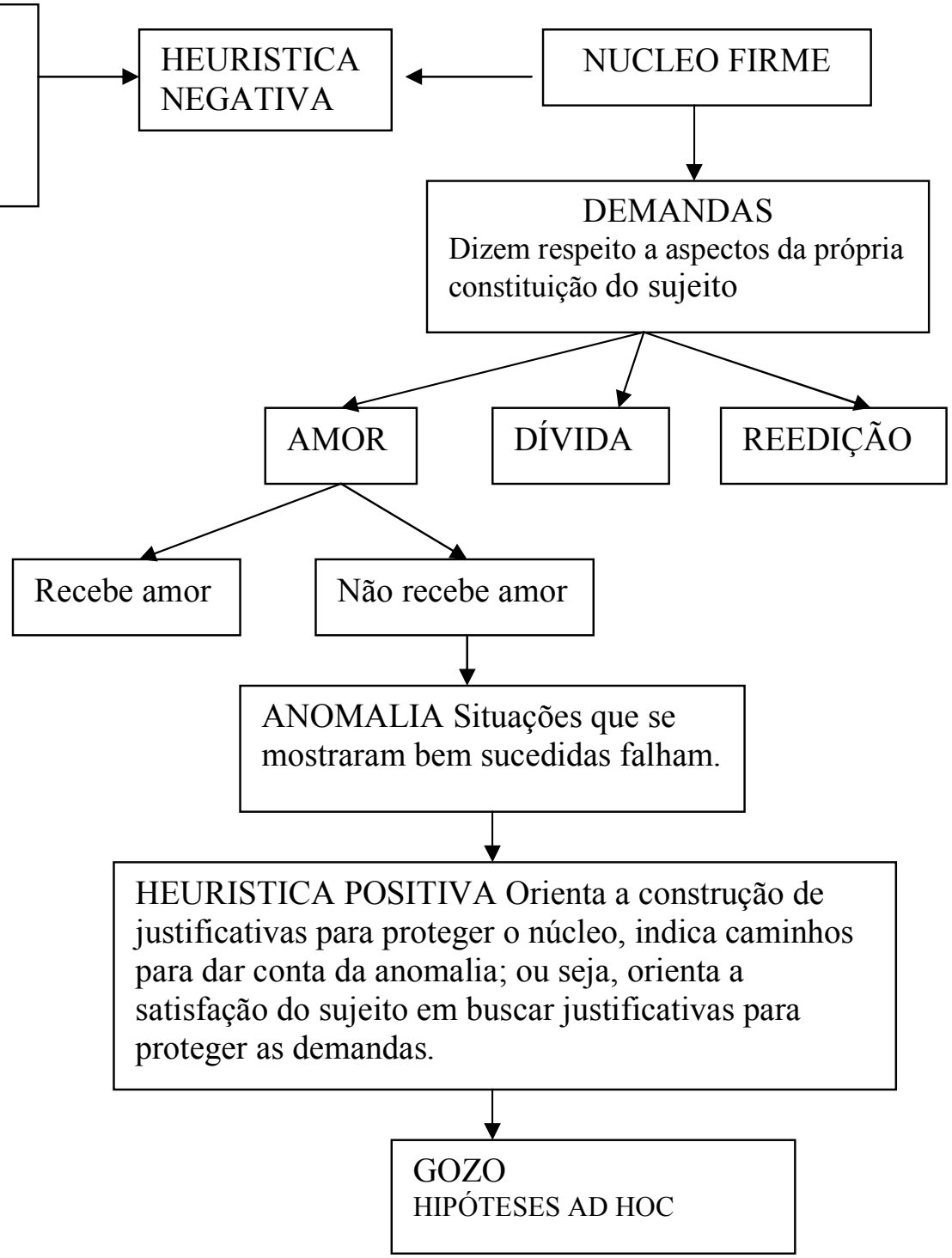


Chamamos a atenção para o fato de que essa analogia com o modelo de Lakatos na sua íntegra, possibilitou um avanço no entendimento da situação. Esse avanço diz respeito ao fato de que, após o estabelecimento da analogia, percebemos que o cinturão protetor não se traduz pelo gozo, como pensávamos inicialmente. O cinturão é formado pelas hipóteses auxiliares, metodologias, recursos materiais, estratégias, teorias de ensino, etc., que se encontram à disposição do professor quando vai promover uma situação de ensino. Esse material, que se encontra no cinturão, sempre que o professor se sentir ameaçado na obtenção de satisfação das demandas, poderá sofrer ajustes e sofisticar suas hipóteses e explicações para conseguir absorver essas anomalias. Nesse caso, estarão constituindo a heurística positiva que orienta a busca de solução e, nessa busca, institui situações de gozo. As hipóteses ad hoc também surgem com o mesmo objetivo de proteção do núcleo firme, mas o seu uso excessivo acaba ocasionando uma degeneração do núcleo.

A partir desse avanço, estabelecemos que, entre as demandas do professor, que estão no núcleo firme, por exemplo, está a de receber amor. Receber amor diz respeito à heurística negativa porque faz parte de um núcleo, que não apresenta confirmação empírica direta e que, portanto, é irrefutável, mas que se torna um referencial para as hipóteses auxiliares, que têm a função de confirmar a satisfação, ou não, da demanda de amor. Se a demanda de amor é atendida, o professor permanece na profissão. Caso contrário, as hipóteses auxiliares, constituídas por metodologias, recursos, estratégias, teorias de ensino, intuições, indícios, etc., estarão se articulando para dar mais solidez ao cinturão protetor. Essa articulação vai desde uma reorganização dos elementos disponíveis para o professor na sala de aula, até a introdução de novas tecnologias, novas teorias, novas idéias, intuições, bom senso, etc., tudo que o professor possa fazer na tentativa de não colocar em risco a proteção das demandas, ou seja, do recebimento de amor.

O significado dessa articulação seria uma modificação, no cinturão do modelo que iria se ajustando e modificando a fim de suportar o impacto dos testes que tentariam negar o que está no núcleo firme, nesse caso, a possibilidade de recebimento de amor.

Então, se o teste se refere a situações que colocam em risco o recebimento de amor pelo professor, a heurística positiva, que diz respeito à articulação dos elementos do cinturão de proteção, começa a elaboração de sugestões e palpites articulados, promovendo mudanças e sofisticações no cinto de proteção 'refutável'. Quando esse cinturão protetor se modifica, pela heurística positiva, inferimos que essa reconfiguração se constitui num gozo, porque ele vai se reajustando e se modificando para otimizar a proteção das demandas do núcleo. Isto significa que, enquanto o professor fica como que paralisado, mesmo que, por muito pouco 
tempo, na busca de soluções para a falta de amor que ele sente como uma ameaça, estará reorganizando tudo que tem disponível no cinturão para promover um ensino eficiente e ainda utilizando novos elementos físicos, emocionais, materiais e teóricos que a sua criatividade permita, para que surjam novas possibilidades de reinvestimento na obtenção de amor.

Nesse processo, há a justificativa de eventos do passado e motivação para criação de novas hipóteses que possam corroborar ou proteger o núcleo em outras situações futuras. $\mathrm{O}$ que quer dizer que fazer esse exercício de proteção das demandas, nesse caso da obtenção de amor, possibilita ao professor uma ampliação de sua rede de saberes, já que ele estabelece maior domínio não só sobre o que está disponível materialmente, mas sofistica sua atuação no sentido de que, cada vez mais, ele cria, ou tem à sua disposição, situações de ensino bem sucedidas que ele próprio vivenciou. $\mathrm{O}$ aumento desse material empírico, recriado com sua intervenção pessoal, envolvendo aspectos criativos, emocionais e até intuitivos, pode ser frutífero se garantir uma segurança em relação às ameaças anteriores e, ainda, de segurança para que ele não tema as ameaças futuras.

Entretanto, se o professor, na busca desse amor, contar apenas com o que está disponível no cinturão; utilizar, sem nenhuma criatividade, esses elementos; e não avançar nessa busca de saídas; estará colocando em risco o atendimento e proteção dessa demanda e, portanto, o conteúdo do núcleo firme. Esse risco pode gerar uma insegurança no professor, que fica mais suscetível, já que há um risco de não conseguir a completude. O núcleo começa a não atender plenamente as suas demandas imaginárias, mantendo a parte correspondente da demanda de amor em situações de gozo, que, se não forem sofisticadas, acabarão comprometendo a proteção das demandas.

Portanto, sempre que o professor consegue proteger o núcleo firme, onde estão as demandas, criando articulações e justificações no cinturão protetor que se estabelece como um gozo e, se essas articulações e justificações forem capazes de criar situações explicativas que se sofistiquem e ampliem as possibilidades de proteção futura do núcleo firme, ele estará paulatinamente se produzindo na profissão. Isto, no sentido de que ele consegue, cada vez mais, segurança e a sensação de ser o dono da situação, acreditando que consegue proteger suas demandas imaginárias das ameaças passadas e das futuras. Caso contrário, se o professor apenas consegue se justificar, não sofistica essas justificações e, ainda, não se sente seguro para criar explicações que possam promover uma proteção futura do núcleo; a produção da profissão entra em degeneração, o que poderá provocar uma desistência da profissão. O que acontece aqui é que a heurística negativa está prevalecendo em relação à heurística positiva e, portanto, o cinturão está perdendo sua força de proteção e o núcleo entrando em degeneração. 


\subsection{MAIS ALGUMAS QUESTÕES}

Se nossa hipótese estiver correta, ou seja, se a analogia apresentada for um instrumento proveitoso para compreender e lidar com a profissionalização docente, uma conseqüência imediata referente aos cursos de formação inicial e continuada pode ser vislumbrada: não é suficiente preparar o professor para enfrentar defensivamente os problemas que ele encontrará ou está encontrando no exercício da profissão, pois isso, na melhor das possibilidades, simplesmente deslocará o momento da crise em relação à profissão docente. Parece necessário que a formação deva ajudar o professor a elaborar instrumentos que o ajudem a avançar na satisfação das demandas: um projeto docente capaz de reverter, globalmente ou localmente, na sua Instituição, ou, ao menos, na sua prática individual, a tendência à desistência da profissão docente. Provavelmente, uma maneira de avançar na satisfação das demandas, seja promover situações em que haja deslocamento das situações de gozo, nem que seja temporariamente, até que se busque uma saída. Mesmo que o professor novamente entre em situação de gozo, por uma nova questão, houve um avanço e o nível de busca de soluções agora é outro.

Partindo da idéia de que os elementos capazes de proteger as demandas do professor estão no cinturão e que a sofisticação desses elementos, ou seja, o avanço que se pode fazer, em termos de hipóteses para resolução de problemas, faz com que a eficiência dessa proteção aumente, nos perguntamos: $\mathrm{O}$ que poderia ser feito para se sofisticar o cinturão protetor? $\mathrm{O}$ que poderia ser colocado no cinturão e que fosse capaz de responder, de forma eficiente, aos problemas e às situações práticas ou imaginárias da sala de aula? O que poderia significar fazer isso em termos práticos?

Já discutimos, no modelo de Lakatos, que o professor tem à disposição, para proteção de suas demandas: a sala de aula, os alunos, os recursos materiais, o seu corpo, a sua voz, as suas hipóteses auxiliares, as teorias de ensino, as estratégias de abordagem de conteúdos, a sua fluência no conhecimento científico, os seus discursos e dramas, suas chantagens, seu poder de decisão, etc. Esse elenco de possibilidades está disponível para absorver as anomalias. Caso isso não seja suficiente, esse elenco pode ser reconfigurado, reajustado, criando e sofisticando novas hipóteses. Mas, em termos práticos, essa sofisticação, ou reforço do cinturão, tem que ser feita de forma a conseguir que o professor aja quase como uma mãe, que nunca desiste do seu filho, ou seja, que nenhuma ameaça o distraia do seu objetivo de 
proteção. Então, como poderíamos conseguir um reforço de tal ordem, que mantivesse o professor sempre direcionado para o atendimento dessas demandas?

Estar na sala de aula garante ao professor a otimização da situação ideal de atendimento, ao mesmo tempo em que consegue colocar em movimento as hipóteses auxiliares que estão sendo reeditadas e reajustadas para ampliação dessa possibilidade de proteção. Portanto, o dito bom professor, aquele que dá certo, pode ser aquele que consiga de alguma forma, escolher dos elementos disponíveis do cinturão, aqueles que articulam melhor o conhecimento prático que tem da sala de aula e que acabam dispondo, quase como curingas, na resolução de determinadas séries e tipos de situações problema. Pode ser também aquele que, diante de um aluno indisciplinado, consegue encontrar no cinturão algo que o ajude, como ameaçar mandá-lo para a direção; chamar a sua atenção e em seguida ignorá-lo; parar a aula e fazer um sermão pequeno falando sobre a sua não colaboração; falar com ele mais tarde fora da sala; falar com os amigos dele e com um draminha pedir ajuda; etc. Evidentemente estes são elementos que já estão meio sofisticados em algum cinturão protetor, de um professor que, aparentemente, pode estar sempre reorganizando as possibilidades de obter sucesso.

Quanto ao professor em formação, alguns obstáculos se fazem presente já que não está em sala de aula e não se sente habilitado, ainda, pelo conhecimento, a assumir a profissão. $\mathrm{O}$ que poderia então propiciar esse escudo protetor? O professor em formação deveria estrear em sala de aula com o melhor cinturão protetor possível. E apesar de muitos dos elementos mais básicos estarem presentes, a articulação entre eles, as inserções de novos elementos ainda não são de domínio desse professor, principalmente, porque a checagem, o desafio das respostas, o funcionamento dos esquemas criados, só podem ser validados, quanto à sua eficiência, quando estiver atuando em sala de aula.

Entretanto, outra possibilidade que poderia resultar como frutífera e que, talvez, fosse capaz de ajudar o bom professor, o novo professor e o professor normal, possa ser o exercício de revelar a própria prática, as suas angústias, aos seus pares. Acreditamos que, quando o professor reunido com seus pares, tem a oportunidade de falar sobre as suas impressões, sobre o que dá certo ou não em sala de aula, abre o precedente para ser consolado e questionado em muitos desses pontos. Responder ou não a esses questionamentos no grupo, não implica em uma desistência do professor dessa compreensão, já que, mesmo não querendo revelar, inconscientemente, trabalha em busca dessa resposta. Com isso, o professor pode estar melhorando o conhecimento de sua prática e também dos motivos inconscientes que o 
conduzem a tais situações. O olhar do outro sobre a atuação do professor pode ser frutífero, porque pode não ser difícil falar para aquele que compactua com o seu sofrimento.

Esse exercício de justificativas e de possibilidades, muito provavelmente, ajuda na sofisticação do cinturão protetor o que, de certa forma, garante a permanência do professor em sala de aula, já que, dá à sua atuação, mais segurança. Dificilmente o professor muda a sua prática porque verifica que um outro professor, usando outra estratégia, se saiu melhor na mesma situação, mas saber da existência dessas possibilidades de atuação, pode representar um reforço positivo para a manutenção do exercício da docência. Acreditamos, entretanto, que existam situações em que o abandono do núcleo não dá para ser revertido, mesmo na interação com seus pares, sendo que o professor permanecerá numa situação de gozo. Como já desistiu, só espera que surjam oportunidades para mudar de contexto - seja uma outra profissão ou, até mesmo, uma outra escola. Um excelente exemplo desse momento já foi dado no caso da $5^{\mathrm{a}} \mathrm{W}$, em que os professores em grupo, incluindo a direção da escola, desistiram de qualquer ação para ajudar os alunos. O discurso comum, do grupo de professores, é que não dá para mudar a situação; que não vale a pena investir esforços; que esses alunos não têm condições de atender às demandas deles. Estão paralisados nesse tipo de gozo e pode ser que não exista nada que os desloque dessa posição.

Se os professores formassem um grupo operativo ${ }^{38}$, existiria a possibilidade de o grupo funcionar de modo a criar intermediários que os deslocassem dessa situação paralisante. Intermediários que os fizessem reconsiderar os eventos e modificar o seu modo de atuação e reinvestir na proteção das demandas. O sentido que utilizamos intermediário aqui é o mesmo proposto por Kaës (1997), que é uma instância de comunicação que une dois termos que estão separados por suas naturezas distintas e, ao mesmo tempo, mantém a separação - no nosso modelo, seriam o cinturão e o núcleo. O intermediário seria a instância que articularia essa diferença produzindo uma simbolização, o que provocaria modificações na realidade. Seria um mecanismo que operaria, segundo Carreteiro (2003), criando um distanciamento das situações em que o professor se sente paralisado e humilhado, não os reforçaria, mas, ao mesmo tempo, trabalharia com os afetos recalcados que estão na base das defesas coletivas.

\footnotetext{
${ }^{38}$ Grupo operativo- "Pichon Riviére desde 1945, que definiu grupo operativo como "um conjunto de pessoas com um objetivo em comum". Os grupos operativos trabalham na dialética do ensinar-aprender; o trabalho em grupo proporciona uma interação entre as pessoas, onde elas tanto aprendem como também são sujeitos do saber, mesmo que seja apenas pelo fato da sua experiência de vida; dessa forma, ao mesmo tempo que aprendem, ensinam também”. DIAS, R. B; CASTRO, F. M. Grupos Operativos. Grupo de Estudos em Saúde da Família. AMMFC: Belo Horizonte, 2006. Disponível em http://www.smmfc.org.br/gesf/goperativo.htm [acesso em 12/01/2008]
} 
Pensando nas transformações que acontecem no grupo, Kaës (1994) diz que o conceito de intermediário funciona nos momentos das descontinuidades, crises ou rupturas do grupo, sendo o mecanismo de passagem entre duas situações conflitantes.

Villani e Valadares (2004), refletindo sobre o conceito de intermediário ponderam:

A noção de crise implica acontecimentos produtores de uma mudança qualitativa de uma situação pré-existente. É considerada uma experiência de ruptura no transcurso das experiências vividas, uma quebra ou modificação imprevista de laços intersubjetivos, e refletem nas atividades didáticas. A noção de crise vincula-se à desorganização, angústia, incerteza, e possíveis ameaças ao projeto educativo. Os intermediários, nesse sentido, funcionam como conector nesses momentos, podendo tanto desencadear movimentos de criação, transformando o grupo, quanto situações de paralisia - quando ocorre uma falha na sua construção -, bloqueando o grupo na consecução de seus objetivos.

Percebemos que o conceito pode nos ajudar a pensar sobre o que poderia ser feito para tirar o professor dessa situação paralisante, de gozo, em que ele pode se encontrar quando não investe mais na sofisticação das hipóteses para proteção das demandas. A crise, aqui, não é a que o professor vivencia e o paralisa, mas a que é capaz de gerar possibilidade de mudanças, ou seja, uma mudança imprevista nos laços intersubjetivos que pode ter reflexo na sua prática. Se há reflexos na prática do professor, conseqüentemente, pode existir a possibilidade de reinvestimento nas demandas.

Estudar as situações grupais de professores nas instituições nos parece promissor, já que existe maior possibilidade de criarem-se intermediários capazes de fazer o sujeito sair de uma situação de inércia, de um gozo que não promove mudança, ou seja, de fazer com que a heurística positiva aja no sentido da busca de soluções para a proteção das demandas. Como os grupos são singulares, de certa forma, as soluções dos problemas envolvem o grupo de professores, os alunos, a instituição e a comunidade, que poderão conjugar suas forças na busca de soluções para provocar um novo investimento que o professor, sozinho, já não conseguia mais fazer.

Como uma última possível saída, proposta nesse trabalho, para a busca de situações de fortalecimento do cinturão, seria uma repetição do que fizemos até aqui. Ouvir as histórias do professor sobre as suas experiências em sala de aula, as suas queixas e, a partir delas, montar o modelo de sustentação da profíssão docente, que elaboramos e que, subjetivamente, cada professor já carrega.

Lembrando que os dados desta pesquisa foram colhidos numa situação ideal, em que foram obtidas informações de professores que corroboraram a sua permanência na docência, podemos, agora, depois de estabelecido o nosso modelo da permanência na profissão, fazer, a 
partir dele, um estudo com os modelos dos outros professores atuantes e estabelecer novas questões: Qual modelo esse professor está usando? O que ele coloca em cada lugar do modelo? O que falta, ou sobra no seu modelo?

Montando essa situação, e lidando com o modelo pessoal de cada professor, talvez possamos perceber e estabelecer os efeitos do recalque ${ }^{39}$ que cada um vivencia e, assim, talvez, ajudá-lo a enxergar saídas que possam promover o fortalecimento da situação na docência, ou seja, é necessário que ele, de certa forma, tome conhecimento de que sua subjetividade está também em sala de aula e que nessa situação estará em busca, mais do que qualquer coisa, do atendimento das suas demandas.

\section{9 ÚLTIMAS CONSIDERAÇÕES}

Diante de todas as considerações que estabelecemos, inferimos que o professor não desiste de sua profissão, enquanto tiver a esperança de satisfazer as demandas subjetivas que dizem respeito à sua própria constituição de sujeito. Essas demandas se re-atualizam e se inscrevem por toda a vida do sujeito, apesar de ele não ter acesso à origem dessas marcas elementares. Quando, inconscientemente, o professor percebe que estar em sala de aula cria uma condição de atendimento às suas demandas originais, ele não abandona a profíssão. $\mathrm{E}$ mesmo que argumentemos sobre a possibilidade de os sujeitos, em outras profissões, estarem vinculados a demandas semelhantes, podemos, a partir de nossas considerações, dizer que o fato de o indivíduo ser professor se constitui numa forma específica de satisfação desses elementos, ou seja, a docência permite que, de alguma forma, essa busca seja feita dentro de uma situação privilegiada que é a sala de aula.

A estrutura explicativa obtida nos sugeriu uma analogia com o modelo dos Programas de Pesquisas de Lakatos (1979). O que, em nossa interpretação, permitiu sugerir que as condições que caracterizam o progresso ou abandono de um paradigma têm a mesma estrutura das que se referem ao progresso ou abandono da carreira docente. Desenvolvendo essa analogia, algumas demandas fundamentais: divida simbólica, reedição parental e demanda de

\footnotetext{
${ }^{39}$ Recalque - no sentido próprio - Operação pela qual o sujeito procura repelir ou manter no inconsciente representações (pensamentos, imagens, recordações) ligadas a uma pulsão. O recalque produz-se nos casos em que a satisfação de uma pulsão- suscetível de proporcionar prazer por si mesma- ameaçaria provocar desprazer relativamente a outras exigências. Extraído de LAPLANCHE, J., PONTALIS, J. B. Vocabulário de Psicanálise. São Paulo: Editora Martins Fontes, $4^{\mathrm{a}}$ edição, 2004.
} 
amor, devem ser protegidas e, portanto, colocadas no núcleo firme. Já no cinturão protetor está o gozo, que possibilita um alívio na tensão quando os elementos do núcleo se vêem ameaçados e o professor entra numa cadeia de justificativas sem fim. A heurística positiva seria aquilo capaz de promover saídas para o deslocamento de uma situação de gozo.

O professor permanece em sala de aula, em nossa interpretação, porque a docência é o lugar que ainda permite renovar, re-atualizar, suas buscas e, quem sabe, conseguir atingir suas crenças imaginárias de completude. Em outras palavras, nossos professores continuam, efetivamente, professores quando conseguem inconscientemente o atendimento das demandas fundamentais e descarregar as queixas sobre a situação atual para o cinturão protetor, com o gozo correspondente.

Se o gozo não possibilitar uma reabilitação do investimento na proteção das demandas, significa que não há busca de novas possibilidades de absorção das anomalias. O gozo fica preso sempre nas mesmas argumentações, não se desloca e, nesse caso, sabemos que o professor começa a desistir de sua profissão. O conteúdo de hipóteses ad hoc pode ter sido ampliado em demasia e por falta de investimento do professor na busca de melhores soluções. A profissão está degenerando porque explica qualquer problema utilizando os mesmos raciocínios e esquemas. Se considerarmos ser professor como um paradigma, o sujeito tem chances de mudar de paradigma e desistir da profissão. Para isso ele deve apostar que essas demandas possam ser satisfeitas pelo novo paradigma, que poderia ser uma nova profissão. Entretanto, se a heurística negativa for maior que a heurística positiva, ou seja, se as hipóteses ad hoc, que deveriam assimilar as anomalias, forem excessivas e não conseguirem ser sofisticadas, a profisssão docente entrará em degeneração.

Para o professor saber que o aluno e ele entram em sala de aula com demandas a serem atendidas, a natureza dessas demandas e a impossibilidade de ter controle sobre como essa busca se processa, talvez seja um elemento que dê certa consciência, ajudando-o a entender e repensar muitas das suas atitudes. Isso pode melhorar a sua performance em sala de aula e, conseqüentemente, a sua relação com o aluno. Com esse novo olhar para a sua situação docente, o professor pode conseguir maior alcance na proteção de suas demandas, podendo se colocar como uma pessoa mais disposta a encontrar intermediários para que a proteção se viabilize e, assim, com essa satisfação, vir a se manter na profissão.

Ressaltamos, ainda, a importância de condições institucionais que ajudem na proteção das demandas e que podem constituir fator vital para a permanência na docência, na medida em que também podem ajudar na criação de intermediários para essa manutenção na profissão. Outro fator seria a mobilização do próprio professor, que precisa ter em vista que 
uma mobilização no sentido de entender seu processo profissional, assim como seu funcionamento pessoal e, até mesmo, seus fantasmas, depende dele mesmo. Essa mobilização poderia ser feita individualmente, ou dentro de um contexto coletivo.

O professor está no lugar que lhe fornece a promessa de um atendimento otimizado de suas demandas subjetivas, portanto, quaisquer que sejam as adversidades que ele encontre em relação à sua profissão, parecerão irrisórias diante dessa promessa. Esse lugar de possibilidades só tem seu potencial reconhecido se ele estiver, de alguma forma, habilitado pelo conhecimento científico a ocupá-lo.

Pode ser que o professor não invista em sustentar esse lugar e mude de paradigma, desistindo da profissão. Mas o que nós esperamos é que a sustentação da docência continue acontecendo e, para isso, precisamos deixar cada vez mais claro o que realmente pode funcionar para fortalecer esse cinturão protetor, sendo este o tipo de questão que tentamos encaminhar para alguma direção neste trabalho.

O professor, então, entra em sala de aula com sua própria História de Vida, com todos esses elementos inconscientes, que dizem respeito à sua constituição como sujeito e, como se não bastasse, também com os fantasmas de seus primeiros professores e orientadores. E são todos eles que, de certa forma, estarão conduzindo suas decisões, reações e, ainda, balizando as situações emocionais que permeiam a sua relação na sala de aula. Os modelos que o influenciaram estão dentro desse arcabouço que o constituiu nessa profissão e ele não tem como ter controle sobre esses eventos e, tampouco, escapar dos seus efeitos. 


\section{REFERÊNCIAS BIBLIOGRÁFICAS}

ALMEIDA, S. F. C. O adolescente e a educação: a função (im) possível dos ideais educativos. In: Escola Lacaniana de Psicanálise do Rio de Janeiro (Org.). O adolescente e a modernidade. Congresso Internacional de Psicanálise e suas Conexões. Rio de Janeiro: Companhia de Freud, 1999. p. $69-78$.

AMADO, J.; FERREIRA, M. M. Usos e abusos da história oral. 4. ed. Rio de Janeiro: FGV, 2001.

AMOSSY, R. Da noção retórica de ethos à análise do discurso. In: AMOSSY, R. (Org) Imagens de si no discurso: a construção do ethos. São Paulo: Contexto, 2005.

ARISTÓTELES. Retórica. Lisboa: Imprensa Nacional, Casa da Moeda, 1998.

ARRUDA, S. M.; UENO, M. H. Sobre o ingresso, desistência e permanência no curso de Física da Universidade Estadual de Londrina: algumas reflexões. Ciência e Educação, Bauru, v. 9, n. 2, 2003. p. 159-175.

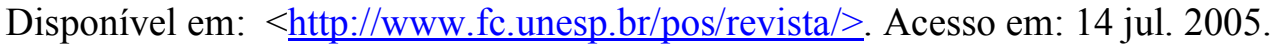

ARRUDA, S. M.; VILLANI, A. Formação em serviço de professores de Ciências no Brasil: contribuições da psicanálise In: III Encontro Nacional de pesquisa em Ensino de Ciências, 2001. Atibaia: Atas do III ENPEC. Porto Alegre: ABRAPEC, 2001. 17 p. 1 CDROM.

AZANHA, J.M.P. Uma idéia de pesquisa educacional. 1990. 201 p. Tese (Livre-docência) Faculdade de Educação, Universidade de São Paulo, São Paulo, 1990.

BAROLLI, E. - Reflexões sobre o Trabalho dos Estudantes no Laboratório Didático. 1998. 228p. Tese de Doutorado - Faculdade de Educação, Universidade de São Paulo, São Paulo, 1998.

BAROLLI, E; VILLANI, A. Laboratório didático e Subjetividade. Investigações em Ensino de Ciências: Universidade Federal do Rio Grande do Sul, Instituto de Física, Porto Alegre, v. 3, n. 3, 1998, p. 145-164.

BARROS, M.; VILLANI, A.; COSTA, Z. F B; BAROLLI, E. Analisando a Dinâmica de um grupo de Aprendizagem de Ciências no Ensino fundamental. In: VII Congreso Internacional sobre Investigación en la Didáctica de las Ciencias, 2005, Granada-Espanha. 
Acta VII CIIDC CD-Rom. Barcelona : Ensenanza de Las ciencias, 2005. v. único. p. 518-522.

BATISTA, L. P. Os jovens de periferia e a escola pública: um estudo de caso. 2002, 200p. Dissertação de Mestrado - Faculdade de Educação, Universidade de São Paulo, São Paulo, 2002.

BENS-PERETZ, M. Episódios do passado evocados por professores aposentados. In: Vidas de Professores. Porto Portugal: Porto, 1995.

BAKHTIN, M. M. Marxismo e filosofia da linguagem. São Paulo: Hucitec, 1986.

BIRMAN. J. Psicanálise, ciência e cultura. Rio de Janeiro: Jorge Zahar, 1994,

BLEGER, J. Temas de psicologia: entrevistas e grupos. São Paulo: Martins Fontes, 1991.

BLEICHMAR, N. M.; BLEICHMAR, C. L. Narcisismo. Papel do outro(a) na constituição do sujeito. In: A psicanálise depois de Freud. Porto Alegre: Artes Médicas, 1992. p. 143-147.

BRANDÃO, H. M. Introdução à análise do discurso. 3. ed. Campinas: UNICAMP, 1994.

BUENO, B. O. Autobiografias e formação de professores: um estudo sobre representações de alunas de um curso de magistério. 1996. 229 p. Tese de Livre docência - Faculdade de Educação, Universidade de São Paulo, São Paulo, 1996.

CARRETEIRO, T. C. Social suffering in debate. Psicol. USP, São Paulo, v. 14, n. 3, 2003. Disponível em: $<$ http://www.scielo.br/scielo.php?script $=$ sci arttext\&pid=S010365642003000300006>. Acesso em: 04 Jan 2008.

CARVALHO, I. C. M. Biografia, identidade e narrativa: elementos para uma análise hermenêutica. Horiz. antropol., Porto Alegre, v. 9, n. 19, 2003. Disponível em: $<$ http://www.scielo.br/scielo.php?script=sci_arttext\&pid=S010471832003000100012\&lng=pt \&nrm=iso>. Acesso em: 25 Fev 2007.

CHARAUDEAU, P; MAINGUENEAU, D. Dicionário de análise do discurso. São Paulo: Contexto, 2004. 
CONTRERAS DOMIngo, J. La Autonomia Del Profesorado. Madrid: Ediciones Morata, 2001.

COUTO, C. G. Professor: O início da prática Profissional. 1998. 713p. Tese de Doutoramento, Universidade de Lisboa, Lisboa: Associação de Professores de Matemática, 1998.

CUNHA, M. I. O professor universitário na transição de paradigmas. Araraquara: JM Editora, 1998.

DIAS, M. C. M. Saberes essenciais ao educador da primeira infância: uma reflexão na perspectiva dos seus protagonistas. 1977. 292 p. Tese de Doutorado - Faculdade de Educação, Universidade de São Paulo, São Paulo, 1997.

DIAS, R. B.; CASTRO, F. M. Grupos Operativos. Grupo de Estudos em Saúde da Família. AMMFC: Belo Horizonte, 2006. Disponível em http://www.smmfc.org.br/gesf/goperativo.htm [acesso em 12/01/2008]

DOBBECK, V. L. A. C. O professor e a categoria profissional: a construção da consciência política. 2000. 237 p. Dissertação de Mestrado - Faculdade de Educação, Universidade de São Paulo, São Paulo, 2000.

FERREIRA, D. B. Revisitando a sala de aula: uma reflexão sobre prática e ações na formação de professores para o ensino de física. 2001. 118p. Dissertação de Mestrado Instituto de Física, Universidade de São Paulo, São Paulo, 2001.

FERREIRA, M. Glossário de termos do discurso. Porto Alegre: Instituto de Letras UFRGS, 2001.

FRANCO, M. A. R. S. Nas trilhas e tramas de uma escola pública: abordagem fenomenológica de um relato de experiência. 1996. 294 p. Dissertação de Mestrado Pontifícia Universidade Católica, São Paulo, 1996.

FREITAS, M.T.A. Narrativas de professoras: pesquisando leitura e escrita numa perspectiva sócio-histórica. Rio de Janeiro: Ravil, 1998.

FREITAS, D; VILLANI, A. Formação de professores de ciências: um desafio sem limites In: I Encuentro Iberoamericano sobre investigación básica en Educación en Ciencias, 2002, Burgos - Espanha, 2002. 
FREUD, S. Além do princípio do prazer. Obras Psicológicas Completas. Edição Standard Brasileira, Rio de Janeiro: Imago, 1976.

. A Dinâmica da Transferência. In: Edição Standard das obras Completas de Sigmund Freud, Vol. XII. Rio de Janeiro: Imago, 1996. p. 109- 111.

GARDNER, H. Inteligências Múltiplas: A Teoria na Prática. Porto Alegre: Artes Médicas, 1995.

JOSSO, M.C. História de vida e projeto: a história de vida como projeto e as "histórias de vida" a serviço de projetos. Educação e Pesquisa, São Paulo, v. 25, n. 2, jul./dez. 1999.

KAËS, R. O grupo e o sujeito do grupo: elementos para uma teoria psicanalítica do grupo. Tradução José de Souza e Mello Werneck. São Paulo: Casa do Psicólogo, 1977.

KUPFER, M. C. Educação para o Futuro. Psicanálise e Educação. São Paulo: Escuta, 2000.

LACAN, J. O Seminário, livro VIII. A Transferência. Rio de Janeiro: Jorge Zahar Editor, 1961.

. O Seminário, livro XI. Os quatro conceitos fundamentais da psicanálise. Rio de Janeiro: Jorge Zahar Editor, 1979.

. O Seminário, Livro XX. Mais Ainda. Rio de Janeiro: Jorge Zahar Editor, 1985.

. O estádio do espelho como formador da função do eu. In: Escritos. Rio de Janeiro: Jorge Zahar Editor, 1998, p. 96-103. Editor, 1999.

O Seminário, livro V. As formações do inconsciente. Rio deJaneiro: Jorge Zahar

. Os complexos familiares na formação do indivíduo: ensaio de análise de uma função em psicologia. Rio de Janeiro: Jorge Zahar Editor, 2002.

. LACAN, J. Nomes-do-Pai. Rio de Janeiro: Jorge Zahar Editor, 2005. 
LAJONQUIÉRE, L. Infância e ilusão (psico)pedagógica: escritos de psicanálise e educação. 2. ed. Petrópolis: Vozes, 1999.

LAKATOS, I. O falseamento e a metodologia dos programas de pesquisa científica. In: LAKATOS, I. e MUSGRAVE, A. (orgs.). A crítica e o desenvolvimento do conhecimento. São Paulo: Cultrix, 1979. p. 102-243.

LAPLANCHE, J. : PONTALIS, J. B. Vocabulário da Psicanálise. 4. ed. São Paulo: Livraria Martins Fontes Editora Ltda, 2004.

LARROSA, J. Tecnologias do eu e educação. In: SILVA, T. T. (Org.). O sujeito da educação estudos foucaultianos. Petrópolis:Vozes, 1994. p. 35-86. 1999. p. 22.

Pedagogia profana: Danças, piruetas e mascaradas. Belo Horizonte: Autêntica,

LÜDKE, M. A socialização profissional de professores, em meio a interdependências e indeterminações. In.: BICUDO, M. A. V. e SILVA, C. A. da (Orgs.). Formação do professor. v. 1. São Paulo: UNESP, 1996a, p. 81-89.

. Formação inicial e construção da identidade profissional de professores do $1^{0}$ grau. In: SCHEIB, L. et al. (Org.) Anais do VIII ENDIPE. Florianópolis - SC: UFSC, 1996b, p. $311-321$.

. A socialização profissional de professores - III etapa: As instituições formadoras. Rio de Janeiro: PUC-Rio, 1998.

MAINGUENEAU, D. Ethos, cenografia e incorporação. In AMOSSY, R. Imagens de Si no discurso. Trad. Dilson F. da Cruz; Fabiana Komesu e Sírio Possenti. São Paulo: Contexto, 2005, p. 69-92.

MANNONI, M. A primeira entrevista em psicanálise. São Paulo: Campos, 1981.

MELO, C. Cartas à redação: uma abordagem discursiva. 1999. Tese de doutorado em lingüística - Instituto de Estudos da Linguagem, Universidade de Campinas, Campinas, 1999. 
MENDES, A. M. B. . Algumas contribuições teóricas do referencial psicanalítico para as pesquisas sobre organizações. Estudos de Psicologia: Universidade de Brasília, 2002. 7

(Número Especial), p. 89-96.

Disponível em: $<$ http://www.scielo.br/scielo.php?pid=S1413-

294X2002000300010\&script=sci abstract\&tlng=pt $>$. Acesso em: 29 Jan 2008

MILLER, J. A. Percurso de Lacan: Uma introdução. Trad. A. Roitman. Rio de Janeiro: Jorge Zahar Editor, 1987.

MOITA, M. C. Percursos de Formação e de Transformação, in: NÓVOA, A. Vidas de Professores. Portugal: Porto, 1995.

MRECH, L. M. Saber e gozo. In: Psicanálise e educação: novos operadores de leitura. São Paulo: Pioneira, 1999. p. 87-103.

MUSSALIM, F.; BENTES, A. C. (Orgs.). Introdução à lingüística: domínio e fronteira. v. 2. São Paulo: Cortez, 2001.

NASIO, J. Cinco Lições Sobre a Teoria de Jacques Lacan. Rio de Janeiro: Jorge Zahar Editor, 1993.

1995.

Os 7 Conceitos Cruciais da Psicanálise. Rio de Janeiro: Jorge Zahar Editor, Como trabalha um psicanalista? Rio de Janeiro: Jorge Zahar Editor, 1999

NÓVOA, A. et al. Profissão professor. Coleção ciências da educação. 2 ed. Porto/Portugal: Editora Porto, 1995.

OGILVIE, B. Lacan a formação do conceito de sujeito. Rio de Janeiro: Jorge. Zahar Editor, 1991.

ORLANDI, E. P. Destruição e construção do Sentido. In: O histórico e o Discursivo. Uberaba: FIUB, 1986.

. As formas do silêncio. Campinas: Editora da UNICAMP, 1993.

PÊCHEUX, M. O discurso: estrutura ou acontecimento. Campinas: Pontes, 1990. 
Pontes, 1999.

Papel da memória. In: Achard, P. et al. Trad. e Intr. Nunes, J.H. Campinas:

PIMENTA, S. G; GHEDIN, E. (Orgs). Professor reflexivo no Brasil: gênese e crítica de um conceito. São Paulo: Cortez, 2002.

PIMENTA, S. G. (Org.) Saberes Pedagógicos e Atividade Docente. São Paulo: Cortez, 1999.

PLEBE, A; EMANUELE, P. Manual de Retórica. São Paulo: Martins Fontes, 1992.

POLLAK, M. Memória, esquecimento e silêncio. In: Estudos Históricos. Rio de Janeiro: CPDOC/FGV/ Edições Vértice, Vol. 2, n. 3, 1989. p. 3-15.

http://www.cpdoc.fgv.br/revista/arq/43.pdf

PORTELLI, A. Tentando aprender um pouquinho: algumas reflexões sobre ética na história oral. In: PERELMUTTER, D; ANTONACCI, M. A. Projeto história: revista do programa de estudos pós-graduados em história e do departamento de história da PUC-SP. Ética e história Oral. São Paulo: PUC-SP, 1997, n. 15, p. 1-293. Abril/1997.

RICOEUR, P. Tempo e narrativa. v. 3. São Paulo: Papirus, 1997. p. 425-428.

RODULFO, R. O Brincar e o Significante: um Estudo Psicanalítico Sobre a Constituição Precoce. Porto Alegre: Artes Médicas, 1990.

RUSSEL, S.; NORVIG, P. Inteligência Artificial: Um enfoque moderno, São Paulo: Campus, 2004.

SANTI, M. C. Crônicas de uma professora. 1993. 142 p. Tese de Doutorado -Faculdade de Educação da Universidade de São Paulo, São Paulo, 1993.

SANTOS, M. E. Mudança conceptual na sala de aula: um desafio pedagógico. Lisboa: Livros Horizonte Ltda, 1991.

SCOTTI, S. Culpa e Gozo, Psicanálise e Literatura. Psicologia: Reflexão e Crítica. Porto Alegre, vol. 16, n. 1, 2003, p. 217-221. 
SHÖN D. Educando o profissional reflexivo: um novo design para o ensino e a aprendizagem. Porto Alegre: Artes Médicas Sul, 2000.

SILVEIRA, F. L. A metodologia dos programas de pesquisa: Caderno Catarinense de Ensino de Física. Florianópolis, vol. 13, n. 3, dezembro 1996, p. 219-230.

SOUZA, L. L; VASCONCELOS, M. S. Organizing models of thinking: a research about moral reasoning with transgressor adolescents. Psicol. estud., Maringá, vol. 8, n. 2, 2003. Disponível em: $<$ http://www.scielo.br/scielo.php?script=sci arttext\&pid=S1413$\underline{73722003000200006}$ >. Acesso em: 20 Agosto 2007

SOUZA, M. C. C. C. et al. Memória, Docência e Gênero: estudos alternativos sobre a formação de professores. Revista de Psicologia da USP. Número Temático sobre Memória. São Paulo (IV), n. 3-4, 1993 (publicado em outubro de 1994).

SOUZA, M. C. C. C. A Escola e a Memória. São Paulo: EDUSF, 2000.

TAVARES, M. A. Inference então as mark of subjectivity construction and meaning actualization in sociolinguistics interviews. DELTA, São Paulo, vol. 20, n. 1, 2004. Disponível em: $<\underline{\mathrm{http}}: / / \mathrm{www}$. scielo.br/scielo.php?script=sci isoref\&pid=S010244502004000100004\&lng=en> acesso em: 01 Fev. 2007.

VILLANI, A; CABRAL, T.C.B. Mudança Conceitual, Subjetividade e Psicanálise. Investigações em Ensino de Ciências, vol. 2, n. 1. março, 1997.

Disponível no site: $<$ http://www.if.ufrgs.br/public/ensino/revista.htm $>$ acesso em: 11 nov. 2007.

VILLANI, A. O professor de ciências é como um analista? Belo Horizonte: Ensaio. Pesquisa em Ensino de Ciências, vol. 1, n. 1, p. 5-28, 1999.

VILLANI, A; BAROLLI, E. Interpretando a Aprendizagem nas salas de Aula de Ciências. In: XXIII Reunião Anual da ANPED, 2000, Caxambu - MG. ATAS XXIII ANPED -CD-ROM. GT04. Didática. Rio de Janeiro: ANPED, 2000.

VILLANI, A; PACCA, J. L. A; FREITAS, D. Formação do Professor de Ciências no Brasil: Tarefa Impossível. Atas do VIII Encontro de Pesquisa em Ensino de Física, Águas de Lindóia. São Paulo, 2000. 
VILLANI, A. VALADARES, J.M. Crise, mudança e o intermediário: o papel do professor de ciências na constituição de relações intersubjetivas . Revista Ensaio. Pesquisa em

Educação e Ciências v. 6. n. 1. Belo Horizonte: FAE/CECIMIG/UFMG, Julho-dezembro de 2004.

Arquivo disponível: $<$ http://www.cecimig.fae.ufmg.br/wp-

content/uploads/2007/12/megalaco.pdf.> acesso em: 12 dez 2007

VILLANI, A.BAROLLI, E. ARRUDA, S. M. FRANZONI, M. VALADARES, J.M. GURIDI, V. FERREIRA, D.B. Contribuições da Psicanálise para uma metodologia de pesquisa em educação em ciências. In: SANTOS, F. M. T.e GRECA, I. M. R. (Orgs.). A Pesquisa em Ensino de Ciências no Brasil e suas Metodologias. Ijuí: Ed. Unijui, 2006. p. 323390. 


\section{ANEXOS}

ANEXO 1 Roteiro para entrevista

\section{ROTEIRO PARA A ENTREVISTA}

a- nome, idade, tempo de profissão, séries em que trabalhou

1. Você se considera um professor? Por quê?

2. Qualquer pessoa pode ser professor? Por quê?

3. Que atributos distinguem a profissão docente das demais?

4. Você consegue tecer uma linha lógica, falando sobre os motivos que te levaram a ser professor?

5. Você conhece algum professor que não deveria ser professor?

6. O que seus pais acharam de ter um filho professor?

7. Quais a lembranças mais marcantes do período da escola, como aluno?

8. Como foi o seu primeiro dia de aula, como professor?

9. Relate bons e maus momentos ocorridos em sua sala de aula. Como foi sua atuação nessas situações?

10. O que o torna professor?

11. O que você acha que o mantém como professor?

\section{Fale livremente sobre cada item abaixo}

O professor que eu sou.

O professor que dizem que eu sou.

O professor que eu gostaria de ser. 
ANEXO 2: História de Vida da pesquisadora

\section{Minha história \\ Dentro de nós há uma coisa que não tem nome, essa coisa é o que somos. (SARAMAGO, 1995, p. 262 $2^{40}$ )}

Nasci numa cidade a noroeste do Estado de São Paulo, chamada Avanhandava, e lá vivi até os dois anos de idade. Depois, devido à profissão do meu pai que era militar, mudamos para diversas cidades do interior como Bilac, Itu, Jundiaí, Mogi Mirim, Mogi Guaçu e finalmente Itapira.

Até o final da minha história seremos oito filhos, cinco meninas e três meninos, nascidos de uma auxiliar de enfermagem e de um carcereiro, que por incrível que possa parecer, tinham ambos sangue tipo $\mathrm{O}$ com $\mathrm{Rh}$ negativo ${ }^{41}$. Não é impressionante como certas conjunções parecem inicialmente fadadas ao sucesso, mas ao final se revelam de um sofrimento incrível? Duas pessoas que nem sei porque estavam juntas, já que declaravam sistematicamente essa incompatibilidade em discussões, ameaças e dramas interpretados, todos eles, na frente dos filhos. Pois é... Conseguiram conceber oito filhos e arrastá-los por esse emaranhado de neuroses e histerias que é impossível descrever aqui. Acho que está dando para perceber o clima no qual nós oito nos estruturamos.

Este tem se revelado, com certeza, o momento mais difícil desse trabalho, pois tenho protelado diariamente entrar nessa seara pessoal. Muito embora uma grande parte desse exercício já tenha sido feito, por solicitação de professores nas mais diferentes disciplinas, que cursei na pós-graduação, ainda me sinto desconfortável em tornar essa exposição, digamos assim, mais pública.

De posse dos retalhos já escancarados de minha vida, comecei uma nova costura, uma nova ressignificação das situações, um outro cozimento de sentido que pudesse me contar, assim como muitos professores me contaram nesse trabalho de pesquisa, sobre a relação da minha história de vida com a profissão docente.

Os primeiros relatos que fiz foram por solicitação de uma disciplina na qual éramos convocados a contar histórias mostrando alguma relação, desde a mais tenra idade, com o conhecimento e com algum tipo de lógica científica e que provavelmente pudessem ser capazes de nos tornar as pessoas que somos hoje.

Pensando na possibilidade dessa relação com o conhecimento estar de alguma forma envolvida com o meu desejo futuro em ser professora, selecionei dois destes episódios, que receberam novos sentidos, já que agora se tornaram justificativas da minha escolha profissional futura.

Episódio 1. Aos três anos, fiz uma 'descoberta', quando olhei para o meu 'peniquinho' reconheci um grão de feijão. Não sei qual foi a lógica que se estabeleceu no meu cérebro, mas acreditei naturalmente que tudo que eu comia podia ser visto depois do 'processo'. O 'enigma' estava no fato do motivo porque junto com o que eu conhecia vinham coisas não decifráveis. O certo é que, a partir daí, esta constatação me levou diariamente à máquina de costura da minha mãe para pegar pedaços de linha colorida e ingerir. No dia seguinte no quintal de casa 'escondida' eu podia ver o meu 'experimento' e com um pauzinho procurar a comprovação da minha 'hipótese'. Não fui propriamente descoberta, mas fui pega obrigando os meus irmãos menores a engolir linhas coloridas.

Episódio 2. Bem, tínhamos em casa um pato e aos três anos eu achava natural que eles deveriam nadar (talvez pelas estórias que me contavam). Como cumprir os desígnios da natureza para aquele pobre ser que só vivia no quintal e entre a terra e a grama?

Bem, tínhamos também um poço...

O momento exato da ajuda que eu dei à natureza me fugiu. Ficou ofuscado pelo barulho das sirenes, as roupas vermelhas dos bombeiros e a figura congelada do pato saindo do poço.

Não sei exatamente porque fiz isto. Mas durante longo tempo acreditei que o pato adooooooooooooorou!!!!!!!!!!!!!!!”

Esses dois episódios ocorreram entre os 3 e 4 anos e antes que levantem a hipótese de que a minha memória é prodigiosa, pensem antes na surra que devo ter tomado por causa desses eventos. Não me

\footnotetext{
${ }^{40}$ SARAMAGO, J. Ensaio sobre a cegueira. Lisboa. Editorial Caminho, 1995, p. 262.

${ }^{41}$ A incompatibilidade de Rh ocorre quando o tipo de sangue da mãe é Rh negativo e o tipo de sangue de seu filho é Rh positivo. Um nome alternativo é doença do $\mathrm{Rh}$. Se a mãe e o pai do bebê forem Rh negativo, não há razão para se preocupar com incompatibilidade de Rh. Rh é uma abreviação para Rhesus.
} 
lembro dessa surra especificamente, mas, algumas das que lembro, devem se encaixar perfeitamente no perfil desses meus feitos.

Continuando a história....

Como éramos oito filhos e a diferença da idade entre eu o Renato e a Lídia era menos de um ano, não me lembro de ter sido cuidada. O que me lembro é de ver a minha mãe sempre cuidando de um bebê e dos cascudos que eu levava para me afastar deles, quando eu era muito pequena, porque depois, quando eu cresci um pouquinho, passou a ser uma das minhas obrigações cuidar deles. Não me lembro de meus pais terem sido carinhosos comigo, parece mentira, mas não me lembro. Como já disse meu pai era carcereiro, tinha quase 1,90 metros de altura e eu tinha muito medo dele, não porque ele nos batesse muito, mas porque eu achava que ele era muito cruel, já que nos tratava como se estivéssemos no exército. A minha mãe era totalmente impulsiva, sem nenhuma razão aparente, pegava uma vara de bambu e ia nos batendo, quem fez e quem não fez apanhava, nós implorávamos para ela parar, mas como boa italiana, nem pensar. Meu pai era mais cruel (ele só batia com a mão, mas batia muito na cabeça) e o pior eram os sermões quilométricos que duravam vários dias, ele voltava toda hora na mesma tecla com a mesma energia. Acho que fomos criados por dois insanos. O castigo era o único contato físico que tínhamos. Não ganhávamos beijos nem abraços, nem nos davam a mão para andar na rua, ou melhor, nunca saíamos com eles e as mãos deles, no caso, estavam sempre ocupadas em carregar o bebê mais novo. Andávamos em bando e sozinhos. Fazíamos coisas erradas, é claro, mas morríamos de medo das conseqüências, isto eu posso dizer em relação ao meu pai, porque, em relação a minha mãe, o que dá para perceber é que ela não tinha nenhuma lógica nas surras que nos dava. Era muito estranho para mim, quando eu estava no primário e tinha que entregar o cartãozinho do dia dos pais ou das mães. O que acontecia é que eu ficava o tempo todo ensaiando como eu ia entregar, já que não tinha nenhuma intimidade ou afeto por eles, eu acho. Eu não me lembro de ter sido cuidada, amada ou acariciada.

Não é fácil falar sobre isso, mas sempre foi muito dificil ver como existiam crianças que eram queridas e cuidadas. Essas situações que eu vivenciei, podem ser uma das razões pelas quais eu consigo, hoje em dia, uma excelente relação com os meus alunos. O que acontece hoje pode ser algo como uma volta às avessas dessa situação, ou seja, pelo desejo dos cuidados que eu não tive, ou que acho que não tive durante a minha infância. Talvez pela responsabilidade de cuidar dos meus irmãos, de ajudá-los nas tarefas escolares, que sempre me disponibilizo a cuidar, a montar a melhor estratégia para ensinar, a dar conselhos, a descobrir tudo sobre o aluno, etc.

Quando nos mudamos para Jundiaí, eu tinha uns quatro anos, então tão logo nasceram a Beatriz e a Judite. Fomos os cinco, colocados num parque infantil que ficava no lugar em que se localiza atualmente a rodoviária de Jundiaí. Nesse parque infantil fiquei até os dez anos de idade. Evidentemente aos sete anos entrei no primário, mas como éramos muitos e pobres o parque infantil abriu uma exceção, e todos nós podíamos, juntamente com os pequenos, freqüentá-lo no período contrário das aulas do primário ${ }^{42}$, porque além das atividades do parquinho também recebíamos alimentação. Não tenho a menor idéia do porque isso aconteceu, ou como foi que isso foi conseguido, só sei que foi assim... Nós nos sentíamos privilegiados, porque todos saiam do parque infantil aos seis anos e nós pudemos ficar.

Entrei no primário no Sesi (Serviço Social da Indústria) que funcionava dentro da Vila da Vigorelli, uma fábrica de máquinas de costuras, também em Jundiaí. O Sesi atendia basicamente os filhos dos italianos, portugueses e alemães que eram funcionários de alto escalão e que estavam aqui a trabalho e filhos de operários da indústria. Demorou alguns anos, depois que terminei o primário, para eu entender que vivia uma situação diferente, já que estava em contato com uma grande diversidade cultural, muito diferente das outras crianças que viviam nessa época essa fase de escolarização. Quando entrávamos em sala de aula, cantávamos musicas italianas, porque a minha professora do primeiro ano era italiana. Nessa escola eu não me sentia privilegiada, eu não tinha visibilidade, e sabia perfeitamente que as queridinhas dos professores eram a Eva (uma menina alemã) a Graziela (uma italiana) e a Ester (uma portuguesa), portanto não tinha espaço pra mim.

Foi nessa época que eu descobri que isso podia mudar. Tão logo apareceu o primeiro evento cívico, eu fui a única a me oferecer para declamar e, a partir daí, nunca mais eu fiquei, até acabar o científico ${ }^{43}$,

\footnotetext{
${ }^{42}$ Primário: nessa época era denominado primário, os quatro anos iniciais da alfabetização e tinha uma certificação final.

${ }^{43}$ Científico- os três anos finais de escolarização antes do ingresso no terceiro grau. Atualmente corresponde ao colegial.
} 
sem falar, declamar, plantar uma árvore ou hastear a bandeira num evento cívico. Não preciso dizer que eu li o discurso de formatura do primário e que eu nunca vou me esquecer, quando a professora pediu para que eu lesse o discurso para os outros professores da escola, para mostrar como eu tinha jeito com as palavras. Não esqueço dela dizendo: - Prestem atenção como ela diz essa parte... (Me senti muito especial).

No final do primário, não sei bem qual foi a circunstância, mas lembro perfeitamente do meu pai em pé, alterado como sempre, me dizendo que eu seria médica e me casaria com um médico. Dá para imaginar porque eu não sou médica, não é mesmo? A partir daí resolvi que não seria médica, principalmente porque meu pai queria, mas engenheira, só para contrariá-lo. Em todo caso o fato de ter que desafiá-lo, me colocou numa situação de amor e vantagem para sempre em relação à matemática.

No ginásio ${ }^{44}$ comecei uma nova fase, porque agora além da desinibição, conseguia me sobressair nos estudos, ou seja, me tornei visível. Nessa fase já morávamos em Itapira e nessa altura já tinham nascido mais três irmãos o Vicente, o Gilbertinho e a Joaninha, portanto, agora, éramos oito. Meu pai e minha mãe estavam separados (finalmente) e ele estava morando em Taubaté.

Com 11 anos eu tinha uma amiga na minha sala que se chamava Luisa e que morava na minha rua. Eu ia ás vezes na sua casa e acabei conhecendo seu avô, o Sr Atílio, que devia ter uns 70 anos, que tinha uma barba branca, muito comprida, era magro e usava óculos grossos. Ficamos amigos, conversávamos sobre milhares de coisas, ele tinha uma coleção do Clube do Livro completa e ia me emprestando e discutindo comigo as leituras que eu fazia. Nessa época, nos dois ou três anos que fomos amigos até o seu falecimento, eu li a coleção quase toda, que incluía também literatura estrangeira e, conversávamos muito sobre as opções que poderia ter no futuro (não preciso dizer que a Luiza morria de ciúmes). Até hoje eu tenho um livro guardado em que na contracapa, e em sua presença, eu escrevi tudo o que eu queria ser quando crescesse e, algumas dessas coisas, eu fiz.

No ginásio eu era ótima aluna e muito querida pelos professores, a relação não era como as de hoje, mas sentia que era respeitada pelo nível de compromisso que eu tinha para a idade e pelas boas notas que eu conseguia. Os professores, na sua maioria, (não consigo me lembrar de nenhum que não tenha feito) faziam ótimos prognósticos sobre o meu futuro. Isso me dava confiança de que aquela situação na qual vivíamos no momento, os oito filhos e minha mãe, de morarmos num cortiço num bairro chamado 'Pito Aceso', era provisória, pois todos um dia veriam como eu era inteligente e especial. Foi nessa época que aconteceu algo muito marcante e que acredito definiu o meu caminho como professora. As minhas professoras; de literatura, dona Darcy e; de desenho geométrico, dona Zulma, da terceira série ginasial (7.a série hoje) se preocupavam que, devido as circunstâncias, eu como filha mais velha, talvez tivesse que começar a trabalhar e estudar à noite. Ainda no ginásio, resolveram então me indicar com 13 anos de idade, como professora, para os filhos de famílias ricas da cidade para dar aulas particulares e, esse foi o meu trabalho até os 15 anos. É claro que a partir daí eu sempre estava dando aulas de reforço para alguém, apesar de nessa época (15 anos) eu ter começado, porque não tinha jeito, a trabalhar num depósito de ração para animais, como auxiliar de escritório. Não preciso dizer que sempre estudei com os meus irmãos, que todos sempre confiaram que eu podia ajudá-los com o conhecimento e tenho certeza que até hoje é assim.

A confiança que adquiri, de que tudo ia dar certo, teve início com aquelas professoras do parque infantil que conseguiram nos manter dentro da escola. Depois o lugar que consegui no primário, ás custas de minha desenvoltura para falar e me expressar. Mais tarde as minhas professoras do ginásio, que me possibilitaram e confiaram que eu seria capaz de dar conta de uma experiência como professora. Acho que não dá para descrever como eu confiava na minha capacidade de explicar qualquer coisa, já que eu dava aulas também para pessoas adultas. O que chama atenção são os bons prognósticos que eram feitos quanto ao maravilhoso futuro que me aguardava, sejam pelos meus professores ou pelo Sr. Atilio, os quais eu acreditava piamente que se concretizariam. Sou obrigada a admitir que até meu pai via um futuro brilhante para mim.

Chegou o ano (1976) em que eu entrei no Instituto de Física na Universidade de São Paulo, posso dizer que foi uma fase muito difícil de superar porque fui obrigada a reconsiderar minha crença em todas as minhas aptidões naturais, pois tive muitas dificuldades com algumas disciplinas e, principalmente, em entrar nas 'panelinhas' (de meninos) de resolução de listas de exercícios, já que

\footnotetext{
${ }^{44}$ Ginásio- fase de 4 anos intermediária entre o primário e o científico. Hoje corresponde a 5.a,6.a,7.a, e 8.a séries do primeiro grau.
} 
naquele ano na minha sala só havia duas meninas: uma japonesa e eu. O laboratório de física ainda era na Poli ${ }^{45}$ aos sábados e os meninos não nos queriam no grupo deles de jeito nenhum.

Apesar de ter entrado na $\mathrm{USP}^{46}$ eu tinha que trabalhar para enviar dinheiro para Itapira. Consegui um emprego dentro do campus através do $\operatorname{COSEAS}^{47}$ e comecei a trabalhar na Fundação Projeto Rondon que cuidava de projetos na área de educação e que planejava, treinava e enviava universitários de um Estado a outro do país, para atuar nas comunidades carentes do interior desses Estados, com o objetivo de que tomassem contato com a realidade nacional.

Durante todo esse tempo, sempre dei aulas, sempre tive irmãos menores e sempre tinha pessoas indicadas por alguém, a quem eu ensinava o que quer que fosse, já que sempre confiei muito nessa minha capacidade de comunicação. Sabia, nessa altura, que talvez eu não fosse a pessoa mais brilhante, mas me sentia com poder de fazer com que as pessoas entendessem o que eu queria dizer.

Hoje...Eu acredito que tenho um conhecimento sobre como as coisas dentro da sala de aula acontecem. Tenho estratégias para manipular os conteúdos, de tal forma, que eles se apresentem ao aluno da maneira mais clara e de fácil assimilação possível. Estou sempre marcando as situações que são importantes, criando um 'caminho' para que a aprendizagem aconteça e acredito estar sendo seguida pelos alunos. Essa crença vem do fato de que eu sempre estou atrás deles perguntando alguma coisa, olhando o que estão fazendo, mantendo contato, querendo saber das opiniões sobre as dificuldades com o conteúdo, comprometendo-os a ajudarem uns aos outros, ou seja, fazendo uma marcação cerrada para ter o máximo de controle sobre o que está acontecendo. Agora, eu quero 'morrer', quando no dia da avaliação eu percebo que eles não conseguem resolver situações que foram exaustivamente tratadas em sala de aula, ou que não se lembram dos detalhes que eu deixei bem marcados para se pensar o problema. Primeiro surge a sensação de frustração porque não tenho todo o controle que acho que tenho, depois me culpo por não ter esse controle. Continuo me culpando porque eu queria poupálos de uma decepção com a nota e com a física; depois finalmente me culpo por ter que atribuir notas baixas, porque na realidade não tenho segurança de qual é a minha parcela de culpa ou não sobre o que aconteceu. Depois disso começo uma nova empreitada em busca de bons resultados com os alunos, para aliviar essa culpa.

Eu percebo nesse trecho que eu tenho uma necessidade 'doentia' de ter controle sobre os conteúdos, sobre os alunos e sobre as relações que se estabelecem em sala de aula. Do mesmo modo que todos os professores, como não poderia deixar de ser, eu também me culpo pelos maus resultados, pela decepção do aluno; pela falta de controle. Sempre acho que vou conseguir mais sucesso da próxima vez, ou detectar o que falhou, mas não tenho certeza de que realmente estou procurando outros caminhos. Acho que eu acredito tanto nesse meu jeito, que essa crença ultrapassa as minhas dúvidas, já que estou sempre, após alguns ajustes, tentando provar as mesmas teorias.

No meu discurso as justificativas se repetem após os 'insucessos' e percebo que a tentativa de controle que faço nunca implica em pensar realmente em uma nova estratégia, porque é muito forte a crença de que a minha estratégia não tem problemas. Por isso, provavelmente, eu não mude e procure explicações ad hoc ${ }^{48}$ para continuar insistindo nessa teoria. Talvez porque inconscientemente fique presa sempre no mesmo ponto em que me frustrei e não consiga deslocar dessa posição e, de verdade buscar outras saídas.

Uma situação que me enche de orgulho é quando meus alunos declaram que desejam ser físicos ou, quando querem saber quais seriam os conteúdos de física em medicina ou direito. Principalmente porque essas questões, que eles me fazem, não têm nada a ver com o fato de não gostarem da disciplina, mas com a possibilidade de que no futuro, nessa profissão poderão aprender mais sobre o assunto. Gosto de ver a tranqüilidade com que eles lidam com o conhecimento sobre física. Não tomam esse conhecimento como um 'bicho de sete cabeças', não se colocam na posição de acreditar que é impossível aprender os seus conteúdos.

Não tem preço saber que os meus alunos não têm medo de uma das disciplinas mais rejeitadas de que se tem notícia, porque na realidade sinto-me responsável por essa situação. Mesmo que no futuro eles não venham a serem físicos estarão sempre dispostos a retomar esse conhecimento em algum

\footnotetext{
45 Poli- Escola de Engenharia Politécnica da USP.

${ }^{46}$ USP- Universidade de São Paulo.

${ }^{47}$ COSEAS- Coordenadoria de Saúde e Assistência Social.

${ }^{48}$ Hipótese $\boldsymbol{a d}$ hoc ocorre na ciência quando é proposta uma nova teoria científica que conflita com uma teoria já estabelecida, e que não possui um mecanismo explicativo essencial. Propõe-se uma hipótese ad hoc para explicar o que a nova teoria não consegue explicar.
} 
momento de suas vidas. Acho que o que eu mais gosto em mim, como professora, é o meu jeito de ser porta voz desse conhecimento, de conseguir torná-lo palatável e acessível.

Com relação ao conhecimento, percebo o efeito que ele tem de convocar o aluno e colocá-lo numa relação de segurança, de torná-lo capaz de ousar em suas próprias teorias. Quando o aluno sente-se seguro com o conteúdo ele se aventura a fazer relações entre tudo que já viu e que acha tem a ver com o assunto. É claro que, na maioria das vezes, eu também não sei se tem relação mesmo e peço para que nós dois verifiquemos a possibilidade de trazer a resposta na próxima aula. Interessante observar que a relação que estabeleço com os meus alunos, nesse momento em que já temos uma interação pessoal bem estabelecida, faz com que, mesmo eu admitindo o meu não saber, a minha imagem de quem tem um conhecimento sobre o assunto não se modifique para eles.

É muito interessante ver os meus alunos, adultos e muito carentes de uma Faculdade particular que foram beneficiados com o Programa Bolsa Família ${ }^{49}$ e que oriundos de escola pública, apresentam muitas dificuldades em relação aos conhecimentos mais básicos. Pois bem, essa turma tem aulas de laboratório de física e por falta de materiais adequados fazem experimentos com materiais recicláveis. Num experimento de equilíbrio térmico, por exemplo, utilizamos caixas vazias de leite ou suco Tetra Pak ${ }^{50}$, como calorímetro. Evidentemente os erros mais prováveis ficarão, por esse motivo, mais amplificados o que tornará muito mais difícil uma aproximação com os valores tabelados ou calculados com as fórmulas teóricas. Para amenizar qualquer tipo de angústia com os resultados deixo claro para eles que o mais importante é pensarmos os fatores que podem estar fazendo o distanciamento do valor a ser obtido daquele que efetivamente eles obtiveram. Para que haja uma compreensão mínima do que esta ocorrendo eu tenho que retomar a teoria (que eles não tiveram, via de regra, no colégio), explicar o experimento e ainda fazer uma simulação dos dados para que recordem como se fazem os cálculos para a obtenção dos resultados (normalmente preciso recordar regra de sinais, propriedade distributiva, etc...). Bem, depois de todo o trabalho de recordação, não dá para negar o quanto é gratificante ver os grupos em torno do seu singelo material de laboratório, fazendo simulações sobre quais seriam os melhores valores e condições para obtenção de um resultado próximo do 'ideal'. Nesses momentos sinto-me plena, nada me falta, internamente me regozijo de conseguir otimizar, para eles, todo o conhecimento necessário para aquela situação e, ao mesmo tempo estimulá-los a que se lancem a tecer hipóteses sobre os possíveis resultados. Posso dizer até que eles também sentem-se seguros e recompensados pelo trabalho, principalmente quando eu concordo com as lógicas e hipóteses que trazem à tona.

Interessante pensar que mesmo o controle deixa espaço para a surpresa, pois controlar os conteúdos, a forma mais adequada, etc... pode ser capaz de gerar essa situação em que o aluno tem segurança para inovar. De modo geral os alunos reproduzem os meus raciocínios e esquemas, mas é claro que, sempre encontro resoluções e raciocínios que me surpreendem, me orgulham e fazem com que eu enxergue melhor aquele aluno, porque de certa forma eu quero saber como ele escapou dos meus esquemas. O que aconteceu de fato para que ele conseguisse obter essa independência de raciocínio, foi algo que eu fiz ou algo que é inerente a aquele aluno?

Depois de tanto tempo em sala de aula, uma certeza que eu tenho é o fato de querer e precisar do amor e do reconhecimento de meus alunos. Acho importante admitir isso, pois por mais que pareça narcisista da minha parte querer esse reconhecimento, ele se torna muito importante, e quase vital para o professor, principalmente no momento em que surge o incômodo da falta ou da dúvida da existência desse amor.

Vou exemplificar com uma situação que aconteceu, no final de um ano letivo, trazendo à tona essa fragilidade em relação ao amor e reconhecimento que eu preciso que me dediquem (de forma exclusiva, eu tenho quase certeza).

Fui escolhida como paraninfa do terceiro colegial, numa escola estadual, a uns anos atrás. Não que eu não tenha sido escolhida inúmeras vezes, mas sabem como é, cada vez é cada vez. Essa escolha aconteceu uns dois meses antes da data do evento e, um grupo de alunos que cuidavam da formatura me informaram da escolha e, é claro, fiquei surpresa e muito feliz. Esse clima de amor eterno estava indo muito bem até que, um mês antes da data, uma aluna me perguntou se eu já tinha escrito meu

\footnotetext{
${ }^{49}$ Programa Bolsa Escola da Família tem como objetivo maior, beneficiar os alunos egressos do ensino médio da rede estadual pública paulista, com menor poder aquisitivo e, portanto, maior dificuldade em custear seus estudos no ensino superior privado.

${ }_{50}^{50}$ Tetra Pak embalagens constituída de papel, que representa $75 \%$ da embalagem, ela ainda é composta por $20 \%$ de plástico polietileno e outros 5\% de alumínio.
} 
discurso porque eles queriam que eu fizesse nele algumas referencias a como eles eram como alunos ou até mesmo de algumas situações marcantes ocorridas durante o ano. Eu respondi que realmente eu tinha que pensar muito bem como eu faria essa adaptação porque como improvisadora eu sou péssima, pois fico repetindo sem parar a mesma fala e a mesma idéia. Então eu deveria trazer muito bem articulado o que deveria dizer sobre cada um. Aí sem mais nem menos, ela me disse: - Espero que o professor Carlos não improvise o seu discurso. Eu fiquei catatônica, pois descobri, naquele instante, que eu não seria a única paraninfa. Aquilo me pegou tão de surpresa que a minha primeira reação foi de uma infantilidade que revelo aqui sob pena de ser ridícula. Eu disse:- Gente, eu não estou entendendo. Vocês passaram o ano se queixando do Carlos, dizendo que não entendem o que ele fala, que ele não gosta de responder perguntas, que ele é um 'grosso'. Acho que vocês precisam saber escolher as pessoas que realmente estão preocupadas com vocês e....depois de uns cinco, digamos dez, talvez mais, minutos de descontrole e desabafo eu pude finalmente enxergar a 'cara' que eles estavam me olhando. Evidentemente eu tentei, sem cortar o discurso, salvar a situação dizendo que não custava nada eles terem me dito isto antes, afinal de contas, eu gostava muito do Carlos, mas eu podia não gostar e aí.......desatei a falar de várias outras situações que me vieram a mente. De quando eles tinham me contado que não gostavam de uma pessoa, mas que como estavam fazendo um passeio e tinham atividades em conjunto, tiveram que aturá-la. Depois de eu (acho) ter mostrado para eles que eles também podem ser egoístas, fiquei mais calma. Não me senti mais tão 'malvada'. Não me conformo até hoje dessa minha reação absurda. Tudo porque eu não tinha dúvidas de que eu era a única, aquela que tinha o reconhecimento sob forma de todo o amor que eles poderiam me dedicar.

Sobre esse fragmento da minha história, dá para perceber porque é difícil deixá-lo aqui, já que eu também quero deixar estampada aqui a minha melhor imagem, mas infelizmente ou felizmente deixo registrado aqui exatamente como tudo aconteceu. Esse desejo de receber amor e ser reconhecido como o que mais dá amor sempre frustra o professor, porque esse reconhecimento por mais que pareça ser algo impossivel, ele não se cansa de desejá-lo e esperá-lo. 


\section{Todos os nomes de pessoas, locais e instituições foram trocados para preservar a identidade do pesquisado.}

Profissão: Professora de Química no ensino médio e curso pré-vestibular; Professora de prática de ensino I e II e História da Química no curso de licenciatura em Química.

Formação: Bacharel e tecnóloga em química, mestre em química inorgânica, com linha de pesquisa em ensino de química.

Filha de emigrantes europeus, tive uma formação familiar que valorizava profundamente o estudo. Independentemente dos meus pais serem apenas alfabetizados, sempre ressaltaram a importância da escola. Meus pais não interferiram na escolha da minha profissão e a função que incorporaram, foi de me apoiar nas minhas escolhas profissionais de uma forma bastante generosa. Tenho certeza absoluta que abdicaram de desejos pessoais para permitir que me graduasse em um curso que era integral e que, portanto, me impedia de trabalhar.

Optei por química simplesmente porque a professora de química do ensino médio era excepcional, não era uma profissional afetuosa para com seus alunos, mas tinha uma capacidade de nos encantar com a química, de explicar de forma envolvente o conteúdo, que acabei optando por esse curso sem a mínima noção dos caminhos que tal profissão ofereceria.

Ingressei na Universidade no ano de 1979, comecei sofrendo muito com física I, pois como fiz meu ensino médio em escola pública no período noturno, trabalhava durante o dia, quase não tive professores de física, esse era o profissional mais escasso, especialmente para o curso noturno, portanto me faltava base. Os professores partiam do princípio que todos estávamos no mesmo nível. O que mais me agradava no curso era o laboratório, as aulas práticas, o que menos me encantava eram os curso de física e de físico química, ambos ministrados por professores estrangeiros, um peruano e um belga, e estes não apresentavam um bom domínio da língua portuguesa o que dificultava a assimilação em sala de aula. Não fui a pior aluna, mas certamente, não fui a melhor. Tive que correr atrás de tanta deficiência oriunda do ensino médio que me classifico como uma sobrevivente que conseguiu se graduar em 4 anos. No entanto, muito conteúdo se perdeu nessa luta pelo nivelamento com a maioria dos alunos que vinham de boas escolas e com boa formação.

Terminado o bacharelado vim para o campus de São Paulo onde fiz o curso de tecnologia, ou química industrial que me permitiu ingressar na Indústria.

Em 1983 terminei o curso de química industrial, participei de uma seleção e ingressei na Indústria de Cosméticos no departamento de análise de matéria prima e otimização de métodos, lá fiquei quase dois anos, porém a disputa política me irritava e me sentia presa a um sistema com relações humanas difíceis. Não me sentia construindo nada de interessante, apenas colaborando com o enriquecimento de uma empresa sem nenhuma preocupação social, onde qualquer funcionário era facilmente substituível. Diversas vezes presenciei grupos de pessoas, que trabalhavam na produção, sendo demitidos sob a alegação de corte de custos, quando na verdade o que se deseja era exercer uma pressão social e conseguir aumento no preço dos produtos comercializados pela empresa.

Engravidei, parei de trabalhar durante dois anos e meio. Passado esse período comecei a ministrar aulas de química no ensino médio em uma escola pública. No início o magistério era para mim um trabalho que me permitia cuidar da minha filha e ainda colaborar com o orçamento doméstico, acontece que me apaixonei, fiquei na escola pública durante, aproximadamente um ano, em seguida fui para a escola técnica Cristal, experiência extremamente interessante, pois ministrei cursos para químicos, lá fiquei por um ano letivo. Foi então que surgiu a proposta de trabalhar em curso prévestibular, onde mulheres não são bem vindas, principalmente na área de exatas. Consegui me manter no cargo, o salário era ótimo, a pressão era enorme, mas acredito que a experiência nesse tipo de escola foi bastante enriquecedora, pois deve-se ter uma eficiência na transmissão do conteúdo. Porém o professor de pré-vestibular, na minha opinião, é mais um adestrador do que um professor, e embora se tenha um contato humano muito grande, o profissional se perde no meio de suas simplificações e sínteses. Após dez anos atuando neste mercado, resolvi voltar a estudar, sentia que estava claramente perdendo os conceitos no meio da banalização necessária nesse tipo de curso.

Em 1999 iniciei mestrado em Química Inorgânica, com linha de pesquisa em ensino de química. Desenvolvi pesquisa sobre uma abordagem diferenciada para modelos atômicos e ligações químicas 
para o ensino médio. Foi um sonho voltar a estudar, retomar conceitos, comecei fazendo um curso de história da química com o Prof. Beija Flor, que me abriu horizontes para a pesquisa. Em junho de 2002 apresentei meu trabalho e fui aprovada, porém a linha de pesquisa em ensino de química não conseguiu se transformar em área e, o meu orientador não tinha mais interesse em dar continuidade a esse trabalho. Peguei meus pertences e vim para São Paulo a espera do doutorado em ensino de ciências.

O que mais me encanta na minha profissão é a generosidade impregnada nela, pois aprende-se para se poder transmitir, estuda-se para aprender coisas novas e devolvê-las aos alunos de uma forma que os encante, dessa forma sinto-me útil, sinto-me participando da vida dos alunos e colaborando com a melhora dessa vida. Adoro o contato humano com meus alunos, acho que a sala de aula é o local da troca de experiências. Já fui uma professora autoritária, mas isso me gerava muita angústia, ao ingressar no curso pré-vestibular descobri que meus alunos não eram meus inimigos mas sim pessoas que precisavam do meu conhecimento para atingir seus objetivos e eu precisava do contato com eles para me sentir útil nessa vida, fazendo algo além de receber um salário, não era um emprego mas sim um trabalho muito prazeroso. É assim até hoje, claro que alguns dias sinto-me uma péssima profissional, ou ainda, acho que estou ensinando para ninguém, mas passa logo.

Os alunos do ensino médio são jovens cheios de sonhos e esperanças, me alimento de seus sonhos e tento colaborar com a construção dos mesmos, por outro lado, eles fazem recuperar os meus sonhos perdidos em função da dureza que é viver. Os alunos da faculdade são mais maduros, mas também cheios de esperanças com relação ao mercado de trabalho, faço sempre o que considero ser o melhor, converso com eles perguntando se o curso está caminhando da forma desejada, aceito sugestões, e parece-me que estamos construindo um curso interessante.

Que professor sou eu? Acredito que a minha marca seja o bom humor, não encaro o aluno como um ser perdido, acho que são apenas crianças grandes, cheias de energia que algumas vezes é difícil de controlar tal energia durante 50 minutos, tenho meus momentos 'ordem no recinto', mas não consigo ser autoritária todo o tempo, apenas tempo suficiente para não perder o controle da sala. Valorizo demais as perguntas feitas pelos alunos, elas são o termômetro do envolvimento e compreensão do assunto discutido. Depois do mestrado sinto-me mais segura, mais completa e com mais informações não tão específicas, ou seja, sinto-me mais interdisciplinar, o que torna a aula mais envolvente.

Minha postura em sala de aula foi se transformando em função das exigências, ou ainda, da necessidade de sobrevivência no mercado sem que a minha saúde mental e física fosse afetada. $\mathrm{Na}$ escola pública o aluno era responsabilizado por problemas de aprendizagem, já no curso pré-vestibular e escola particular é responsabilidade total do professor a solução desses problemas. Sinto-me responsável pelos problemas de aprendizagem, do não envolvimento com o conteúdo. Minhas salas de aula têm em média 80 alunos, no cursinho uns 120 alunos, se a maioria tem dificuldade ou considera o conteúdo entediante, ou mesmo não gera participação, tento renovar minha aula, seja com novos exemplos, questionamentos ou experimentos. Estou, na maior parte do tempo, questionando sobre a melhor forma de apresentar determinado assunto. Atualmente encaro essa angústia não como uma incapacidade, mas uma necessidade que força a renovação. Percebo também que não precisaria ser necessariamente professora de química, o importante é ser professora, e a química foi uma questão de afinidade em função de uma boa profissional.

O que ser professora significa para você?

R.: Uma forma de garantir meu sustento de uma maneira agradável. E ainda, ser professora significa colaborar com meus alunos a atingir seus objetivos: no curso pré-vestibular entrar na faculdade, no ensino médio fazê-los explicar o mundo utilizando linguagem e pensamento científico e na faculdade colaborar na formação de um profissional ético e satisfeito. Sei que não consigo ajudar de maneira efetiva a todos meus alunos, mas fico feliz com os resultados positivos atingidos por alguns e estou sempre estudando e repensando meu trabalho para ser mais efetiva nas minhas tarefas.

Você estudava com amigos, ou ensinava seus amigos na época de escola?

R.: Não, sempre gostei de estudar sozinha, as vezes, quando questionada ajudava, mas era muito tímida e não me relacionava com muitas pessoas durante o período escolar, principalmente no ensino básico, depois, no ensino médio, trabalhava de dia e estudava a noite então pouco encontrava os colegas para estudar, cada um se defendia como podia.

Você não deu nenhuma informação sobre quando você era criança e sobre a sua entrada na escola 
Essa parte não me agrada muito relatar, traçarei linhas gerais, morava em uma cidade litorânea com escolas muito rudimentares e com professores muito mal preparados, o castigo fazia parte das aulas, reguadas, castigo no milho, puxões de orelha, humilhações... Esse período foi muito traumático e acredito que algumas das minhas dificuldades na escola, embora nunca tenha sido reprovada, deva-se a um medo imenso dos castigos. Essa fase assustadora durou 4 anos, depois meus pais me trouxeram para São Paulo, com escolas mais civilizadas, mas o estrago já estava feito, a escola não foi para mim um lugar de relacionamento e amizades, mas sim um lugar onde tinha uma obrigação a fazer, estudar, tirar o diploma e chegar a faculdade, meta que meus pais sempre valorizaram. Às vezes me questiono como consegui chegar onde cheguei com todos os medos que desenvolvi nesse período negro.

O tempo de escola

$\mathrm{O}$ curso de física foi muito prejudicado pela falta de profissionais da área na escola pública, não aprendi física no colégio, mas sim no curso pré-vestibular. As aulas de química eram teóricas, nunca tive laboratório, muitas listas de exercícios com avaliação oral. Nunca fui uma aluna excepcional, mas não ficava de exame e nem nunca fui reprovada, não me lembro especificamente quais eram as minhas notas, mas química era a matéria que eu ia melhor. As recordações que guardo da minha professora de química são: ela tinha a aparência de uma freira, pele muito pálida, nenhuma vaidade, não sorria muito, não era afetuosa, mas era muito dedicada nas explicações e no atendimento das dúvidas dos alunos.

Como você está na disciplina

Gosto do curso, do formato, das discussões, dos colegas, enfim está sendo muito produtivo.

Acho que sou um pouco tagarela e empolgada, preciso aprender a me controlar um pouco. Por outro lado, alguns colegas são mais tímidos, outros mais extrovertidos, mas sempre ocorre uma colaboração de todos no enriquecimento da aula. Acho um grupo interessado e participativo. 
ANEXO 4: História de Vida Maria

\section{Todos os nomes de pessoas, locais e instituições foram trocados para preservar a identidade do pesquisado.}

Bem, minha entrada no Mestrado aconteceu muito tempo depois de eu ter me formado na Faculdade, embora eu veja no ambiente de aulas que tenho freqüentado, como isso é diferente. Hoje, os alunos formam-se e, praticamente de imediato, já ingressam no Mestrado. Claro que analiso isso com aspectos positivos e negativos, pois quando se tem mais experiência eu acredito que se valoriza mais o que se faz, quando eu era mais nova, muito do que eu fiz, foi por sugestão dos meus pais, que sempre procuraram orientar os filhos no processo de crescimento e amadurecimento. Por outro lado, me dediquei tanto em adquirir experiência, fazer cursos de atualização como professora, que me distanciei demais do meio acadêmico, de minha própria formação, que eu tento, agora, retomar. Tenho um grande amigo, de muitos anos, que costuma dizer que eu procurei tanto me especializar em como dar aulas, que esqueci de mim mesma, do crescimento de minha carreira.

Quais são minhas expectativas com relação ao Mestrado? Bem, hoje, minha perspectiva e conseguir ser professora de uma boa faculdade, de preferência em um Curso de Química, que sempre foi minha paixão. Estou preparada para não parar no Mestrado, mas continuar até o Doutorado, pois só assim acho que conseguirei o que espero para minha carreira. Gostaria de me aposentar como professora de Ensino Médio e ingressar em uma boa faculdade, como a Taubaté. Quanto à escrever minha dissertação, percebi que o melhor, para mim, seria me basear em minha prática de professora e, a partir daí, escrever sobre a aplicação de estratégias de ensino e a aquisição aprendizagem significativa. Tenho um tempo para isso e vou fazer o possível para não estendê-lo, pois também faz parte do meu projeto. Um medo que eu tenho é o de não conseguir cumprir os prazos, segundo minhas expectativas, pois trabalho em Escolas que costumam exigir dedicação e atenção, e tenho sempre que me dividir, o que não tem sido fácil, além das relações de família, que me exigem um tempo muito bom, porém nem sempre fácil de ser conseguido.

Assim, quando retorno no tempo e relembro minha vida, no aspecto ensino - aprendizagem, a primeira coisa que me vem à mente é a forma como fui educada, no sentido de ter sido sempre muito estimulada à leitura, a ter tido sempre um acompanhamento muito próximo principalmente de meu pai, que foi e tem sido um orientador em meu percurso. E a sua mãe? Fale um pouco dela Minha mãe sempre apoiou meu pai em suas decisões, pelo menos perto de nós, mas nunca foi uma mulher de se sentar para ler um livro, gostava muito do trabalho de casa e de cozinhar. Além do que, cresci ouvindo que eu, para nascer, quase matei nós duas, que era muito grande, nasci depois da hora, fiquei roxa por quase 1 dia inteiro, e talvez por isso, nunca me dei muito bem com ela, só depois de moça, percebi que quem tinha de mudar era eu, se eu queria Ter um bom relacionamento com ela e foi o que aconteceu. Passei a não levar a sério seus comentários mais chatos, a compreendê-la melhor nas suas razões (quando ela estava grávida de mim, perdeu a mãe de forma inesperada, com um câncer que a levou em cerca de 40 dias, e sua mãe sempre foi uma espécie de ídolo para ela, por sua luta e força (meu avô não teve muito juízo, gostava de jogar, foi aventureiro e ela teve que criar as filhas praticamente sozinha, pois não agüentou aquele companheiro). Hoje, somos boas amigas, mas minha identificação para conversar sempre foi com meu pai. Desde pequena, livros e pequenas coleções acompanharam minha vida, conversas sobre o que eu havia lido, o que eu havia gostado mais (Coleções como Tesouro da Juventude, Monteiro Lobato, depois Shakespeare fazem parte dessas lembranças).

Entrei na escola aos sete nos, já na primeira série, com um medo tremendo de não corresponder às expectativas de meus pais, como filha mais velha, o "exemplo" constante aos irmãos mais novos! Para minha sorte, nunca tive grandes dificuldades, sempre gostei de estudar e a vida foi passando, até que cheguei ao Colegial, em uma escola nova, imensa (para mim), impessoal, onde tive grandes dificuldades (de relacionamentos, de acompanhamento do ritmo da escola, da falta de ser tratada como pessoa, e sim como "algo" a ser adestrado e aí, uma grande decepção com meu pai. Quando falei a ele como era essa escola, ele me respondeu: "A escola tem uma ótima fama, capricha no conteúdo e vai lhe dar base para fazer uma boa faculdade, é lá que você vai ficar até o final do colegial." E eu fiquei, embora não tivesse constituído vínculo algum com o Colégio ou com os padres. Claro que depois de algum tempo, eu tinha minha turma, era muito bom encontrar com o pessoal, estudar juntos, aprontar o 
que eu nunca havia feito antes (cabular aulas, ou tentar, fugir do colégio, pular a janela da sala, enfim a tentativa de ter uma disciplina dura, rígida, funcionava ao contrário para mim).

Na segunda metade do ano letivo, entrei em um cursinho, estudava de madrugada, mas não entrei na USP, o que eu ganhei foi uma gastrite, uma infecção intestinal, um esgotamento nervoso, tudo no final do ano. Voltei a fazer o cursinho durante o ano todo e prestei novamente o Vestibular. Entrei em Química, apenas, para surpresa dos professores, que também me conheciam, mas eu sempre fiquei muito nervosa em exames, e isso acabou me prejudicando muito.

Cursei e adorei, tanto que gostaria de voltar como professora, pois tive um curso sério, bom de qualidade, na minha opinião. Logo no último ano, procurei uma colocação em escolas, encontrei um Colégio Estadual e comecei a dar aulas à noite e acabar meu curso de manhã. Prestei o exame para me efetivar, passei ainda sem o diploma, me efetivei e fiquei na mesma escola por 15 anos de 1978 a 1992, quando pedi remoção para uma escola mais próxima de casa, e que tivesse o Ensino Médio à tarde. Não era uma escola tão séria quanto a que eu tinha saído, não havia aulas como na outra, eu comecei a me sentir enganando os alunos, pedi afastamento sem vencimentos e apostei somente na escola particular. Voltei apenas para pedir minha exoneração da Escola Estadual, embora sempre tenha pensado que o Ensino Oficial é que deve ser incentivado, não achando muito lógico o que aconteceu. Quanto às minhas experiências em sala de aula, mesmo no Colégio em que eu não tive identificação, sempre fui incentivada a praticar ciência, sempre tive aulas de laboratório, sendo que meus professores de Ciências Exatas tinham aulas mais interessantes do que os de Ciências Humanas, principalmente de História e Geografia, o professor de História era tão nervoso que a classe apostava quantos minutos iriam levar para ele chutar o apagador, e o de Geografia, que, quando ficava nervoso mandava todos os alunos para a Amazônia, não tinha paciência principalmente com minha deficiência em noção espacial, logo se irritava e muitas vezes me ridicularizou frente à sala.

Já os de Ciências, Química, Matemática, eram mais felizes, segundo me parecia, davam aulas com prazer, gostavam de nossas dúvidas, tentavam muitas vezes até nos orientar em nossas profissões. Me lembro que as aulas em que o professor falava sem parar, que eram de História e Geografia, me faziam ir longe nas minhas imaginações, eu saía da sala de aula a voava em pensamento, o que não acontecia nas outras aulas, principalmente nas Ciências, em que estávamos mais ocupados o tempo todo, apresentando idéias sobre problemas que os professores propunham a nós, discutindo com a sala toda e o professor sobre temas apresentados, eram professores que não detinham para si todo o tempo da aula, eles dividiam com os alunos, o que tornava o tempo mais bem distribuído e menos cansativo.

As aulas de Português também eram sensacionais, havia textos em que trabalhávamos, temas interessantes de redação (nunca esqueço de um que era: "Sonhei que era um Carneiro Assado", em que eu tirei dez, pois ficava feliz, na minha redação, em ser primeiramente admirada e depois saboreada com prazer!), trabalhos de apresentação que gostávamos de fazer, enfim, participávamos mais das aulas.

Já na Faculdade, encontrei pessoas que foram ótimas amigas (acho importante manter algumas amizades desde o tempo de colégio, faculdade, até hoje), tínhamos muitas aulas práticas, comecei a ver mais conscientemente a aplicação dos conceitos científicos e, embora tenha tido grandes dificuldades, gostei muito de ter a prendido os Cálculos I e II, foi como se tivessem dado um empurrão em minha capacidade de raciocínio. Participei de estágios sobre água, cimento, tintas, fui monitora do laboratório de Química Orgânica, enfim, me dediquei e gostei demais do curso que fiz.

Quando comecei a trabalhar, levei muito do que acreditava para a sala de aula, sempre procurei não falar a aula toda, tirar as idéias dos estudantes, fazer aulas práticas que se relacionassem com a teoria, e dessa forma, acabei sendo indicada em 1984 para fazer parte de um grupo de professores que começou a esboçar as mudanças no Currículo de Química do Ensino Médio. Foi muito bom ter ficado cerca de dois anos nesse grupo, até que a escola particular apareceu com mais força em minha vida e eu acabei não conseguindo tempo para tudo. Larguei o grupo e continuei a trabalhar mais intensamente em sala de aula.

À medida que o tempo foi passando, senti que já era momento de investir em minha carreira, no sentido de ir para uma faculdade, indo fazer o Lato Sensu em Química, e também adorei o curso. Achei os professores muito competentes e um curso bem elaborado. Na verdade, a idéia mais concreta para fazer o Mestrado aconteceu em conversa com minha professora de Físico-química, Prof ${ }^{a}$. Dra. Marcela, que contou sua história, como fez o Mestrado, com quarenta aulas semanais, e mais tarde o 
Doutorado, já mais tranqüila, com mais tempo e melhor qualidade de vida. Há ainda, professores que mantém contato conosco até hoje, o que também é muito bom, sendo um bom estímulo.

Tenho a sorte de ter uma família que apóia minha iniciativa de estudar, que me ensinou a ter um vínculo de valorização com o conhecimento, além de um companheiro que também estuda, dividindo comigo as dúvidas, a angústia, o cansaço que muitas vezes temos que superar para continuar com diversas funções e nem sempre sendo valorizados no aspecto profissional (infelizmente, a escola, para conseguir manter seu número de alunos, aceita e impõe condições de bastante sacrifício e pouca valorização do professor).

Tenho gostado muito das disciplinas que estou cursando no Mestrado, sendo que percebo o quanto têm me ajudado a entender e procurar novos caminhos na minha profissão, no meu dia-a-dia.

Assim, chego aos dias de hoje, fazendo uma análise do produto que eu represento, como professora, depois de tantos anos e de tantos modos diferentes de ensinar, sinto que há uma busca permanente em mim, por mais qualidade, mais conhecimento, mais realização do que eu acho fundamental para um professor: contribuir para formar um mundo melhor, mesmo diante de tantas adversidades que nos coloca o mundo atual, em que o estudo já não representa uma garantia de emprego, de futuro, como no passado.

Quanto ao aspecto do que me foi ensinado, como foi ensinado e como ensino hoje, considero que procuro manter o mesmo interesse pelas idéias dos alunos, por seus interesses, que os professores que mais admirei mostraram a mim.

Acredito que a postura de respeito, seriedade, transparência que sempre tentei mostrar a meus alunos, que minha paixão pela Química como ciência que ensina a ver o mundo sob uma óptica mais profunda, mais humana, mais explicada dos fenômenos com os quais nos deparamos, seja uma direção que sempre procurei manter, em qualquer que seja a escola em que eu estivesse, que isso_vai ficar na memória dos meus alunos e que eu considero mais importante do que memorizar simplesmente conceitos químicos.

Sei que erro muito, até por tentar alguns novos caminhos, por buscar uma qualidade e motivação maior dos estudantes, mas tenho tentado me fundamentar cada vez mais para depois testar novas experiências. E é nessa busca que pretendo desenvolver minha dissertação de Mestrado, que sei que não trará grandes respostas, mas abrirá novos estudos para um futuro Doutorado. É o que eu espero para mim e para a Educação Química.

O que ser professora significa para você?

Não sei se é uma idéia ingênua, hoje em dia falar dessa forma, mas acredito que, sendo professora, posso contribuir de alguma forma para o futuro do país em que vivo, para uma melhoria do futuro das novas gerações e trabalho nesse sentido. Procuro orientar meus alunos, sempre que possível a respeito da responsabilidade de se freqüentar uma escola, de ser, de alguma forma, diferenciado na sociedade e a responsabilidade que isso traz. Portanto, muitas vezes sei que a química e muitos conceitos vão se perder se meus alunos não continuarem a estudar essa ciência, mas o que fica do relacionamento e do vínculo que criamos permanece e espero ser importante para a vida deles.

Você estudava com amigos, ou ensinava seus amigos na época de escola?

Antes de entrar na escola, eu brincava que era professora, me lembro que eu tinha a idéia de que professor era muito bravo, talvez por meu pai ser muito severo nos limites que nos colocava, então, além de pedir giz à minha mãe, eu tinha também uma régua para bater na cabeça das crianças que me desobedecessem. Que coisa louca, não é? Não me lembro de estudar freqüentemente em grupo, meu pai costumava me ajudar nas minhas dúvidas, apenas no colegial comecei a estudar física com alguns colegas, no $2^{\circ}$ ano, pois o professor era um padre que não ensinava absolutamente nada, ele errava os exercícios, não conseguíamos acompanhar seu raciocínio, e procuramos um professor particular, em grupo, e estudávamos juntos, para ver se conseguíamos entender, já que a esta altura, meu pai já não se lembrava de física para ,e ensinar.

Quando fiz meio ano de cursinho, no $3^{\circ}$ ano, também estudava com um pequeno grupo, com três amigas, fazendo as revisões juntas, depois das aulas ( do colégio de manhã, e do cursinho à tarde).

Você não e nenhuma informação sobre quando você era criança e sobre a sua entrada na escola, e se você tiver tempo poderia ir completando o seu texto com informações mais detalhadas.

Quando entrei na escola, fui direto para o $1^{\circ}$ ano do Primário, estranhei pouco, acho que acompanhei bem, gostava muito da minha professora e de todas as que eu tive nesses 4 anos. Lembro de todas, inclusive de Dona Celina, do $4^{\circ}$ ano, ela queria melhorar minha letra, então eu acertava todas as 
atividades, mas ela me avaliava sempre em 60 , e não 100 , me pedindo para melhorar a letra. Sugeriu aos meus pais que eu voltasse a fazer caligrafia, fiz, consegui o 100 de nota e voltei para minha letra feia, acertando tudo e fazendo tudo rápido, sem me incomodar mais com o 60 ou 70, sabia que poderia melhorar a letra quando quisesse e que eu sabia tudo o que ela ensinava!

Na escola como era?

Física não me traz, no geral, traz lembranças bem variadas, meus professores foram um japonês muito engraçado, mas que não tinha facilidade de transmitir os conteúdos, então eu gostava de como ele brincava, mas não entendia muito. Não havia aulas de laboratório, era somente na lousa. Não havia pesquisas, enfim, era tudo muito igual.

Depois dele, veio o Padre Conde, que não sabia nada de física, acho que ele se prevaleceu de ser importante na escola, e aí percebemos que éramos felizes e não sabíamos!

$\mathrm{Na}$ Faculdade, a única matéria em que fiquei de DP foi Física I. Não gostava da aula, o Prof., que me parecia competente, era muito triste, estava sempre chateado, disseram que ele havia perdido recentemente a esposa e sua aula era realmente muito triste. Então, com uma liberdade que eu nunca havia tido, era preferível ficar fora da aula, conversando, estudando outras matérias, do que ficar na aula dele, foi o que eu fiz. E fiquei de DP.

Depois disso, percebi que tinha de me dedicar mais, mudei meu procedimento e aprendi a ficar nas aulas $\left(2^{\circ}\right.$ e $3^{\circ}$ anos) e passei normalmente, mas sempre sem a paixão pela disciplina.

Já em química, tive professores extremamente exigentes, mas muito capazes e nos quais eu conseguia ver uma razão para tanta exigência. Um dos meus professores, Prof. Antena, nos fazia mostrar as mãos depois das aulas de laboratório, se estivessem manchadas, éramos descontados, tínhamos que trabalhar com método e cuidado e isso me ajudava a acompanhar melhor as experiências, entender o que ele queria que víssemos ou verificássemos, já que as aulas práticas tinham esse cunho quando eu fui aluna do colegial.

$\mathrm{Na}$ faculdade, adorava as aulas de laboratório, sou do tempo da "baldoquímica", fazíamos experiências com béqueres enormes, era emocionante obter os produtos, acompanhar os comportamentos das substâncias, fazer os estágios que a escola oferecia, eu me realizava no laboratório. Tanto que, logo que comecei a ser professora, na escola estadual não havia laboratório, mas assim que eu pude, implantei um, lavei, arrumei, organizei e trabalhei como achei que deveria, acompanhando a teoria com a prática.

Voltando à comparação entre a física e a química, quando comecei a dar aula num colégio particular, que tinha um super salário em comparação com o estadual e precisei "pegar" aulas de física, sendo que esta foi a minha oportunidade de estudar e aprender um pouco mais. Eu era professora de química e física da mesma turma e sabe o que eu ouvia? Que eu era melhor professora de física do que de química, que eu explicava melhor física do que química! Compreendi que talvez fosse porque eu explicava física para mim, e química eu já compreendia, então não era tão detalhada.

Como era seu desempenho nas avaliações?

Nunca fui uma aluna de tirara 10,0 no colégio, somente na faculdade, nas químicas, aí me revelei realmente apaixonada e com grande facilidade para aprender os com conceitos da química.

Nas outras disciplinas, também fui regularmente bem, sendo que Português, Matemática, Inglês e as Ciências foram, para mim, mais fáceis de assimilar do que História e Geografia. Assim, nunca repeti de ano, mas nunca fui, principalmente no colégio uma aluna destacada pelas melhores notas da escola. Outra matéria da qual gostei muito foi Artes e também a Redação, adorava escrever histórias criativas sobre os temas apresentados.

Seu professor? Como ele era? Ele ensinava bem?

Você quer saber da química, então lá vai. Meu professor, como já relatei, era enérgico, bravo mesmo, mas explicava muito bem, eu acho que ele adorava a química, pois passava para nós todos um amor ao que ele ensinava que muitos de nós seguimos carreiras ligadas às ciências, com ênfase em química.

Você ensinava seus colegas de escola?

Não, eu estudava com alguns, fazia lição quando me pediam, explicava as dúvidas que eu conseguia tirar, mas nunca fui professora dos meus colegas.

Fale um pouco sobre a sua participação em sala e dos seus colegas de grupo.

Embora eu não seja a pessoa que mais falo nas discussões, acompanho muito e retiro o que para mim é fundamental, portanto gosto muito das discussões. Como vejo que algumas vezes as pessoas são tão repetitivas em falar a mesma coisa em dizer coisas que parecem óbvias, me policio para não fazer isso. 
Acho que é por isso que não gosto de falar à toa, além de ter sido formada por um método na escola em que era mais pensar do que falar.

Como está sendo a experiência de elaboração do seu esboço de projeto?

Difícil, além de tudo por um excesso de afazeres que não tem me permitido grande dedicação para escrever esse projeto. Não vejo a hora que chegue julho para poder escrever melhor as idéias que hoje estão tão mal organizadas ainda. O que eu acho muito bom é o tipo de inquietação que nos causa, como elaborar uma idéia de forma completa em relativo pouco tempo, com os questionamentos que temos. (Agora, 11/6, parece que estou me definindo melhor, escrevi um rascunho do qual gostei sobre minha experiência no estudo do meio)

Qual a ligação que você consegue ver na sua história que te trouxe até aqui?

Consigo, sim. Ingressei por Ter me encantado, quando iniciei. É como se o fato de eu poder ajudar algumas pessoas a se formarem, a crescerem em suas vidas, me causasse um sensação de extremo bem-estar. Isso durou um bom tempo, alguns 14 a 18 anos. À medida que o tempo foi passando, é como se o fato de estar lecionando não representasse mais a mesma coisa que era antes (não vejo mais a seriedade nos estudos, nas intenções de alunos para com professores e de escola para com professores). Se um aluno vai mal, é como se o professor tivesse que explicar o que houve com ele, os pais hoje parece que não conseguem mais se fazer respeitar, e isso está refletindo nitidamente na escola, principalmente na escola de ensino médio, em que os alunos não são mais crianças, mas também não são responsáveis por seus atos. Só que, para mim, o ensino e questão de levar meu trabalho a sério, é um desafio, preciso que dê certo, não estou para fazer experiências e sim para ajudar efetivamente a formar cidadãos, então fui para a pesquisa, tentando melhorar minha prática, torná-la mais coerente e consistente, em busca de ferramentas que me ajudem e aos que buscam como eu a grande saída para a sociedade na educação. 
ANEXO 5: História de Vida Deise

\section{Todos os nomes de pessoas, locais e instituições foram trocados para preservar a identidade do pesquisado.}

Nasci no interior de São Paulo e vim para São Paulo com 2 anos de idade. Minha família era composta por pai, mãe, um irmão dois anos mais velho e uma irmã 6 anos mais nova que eu). Estudei em escolas públicas na zona leste de São Paulo. O ensino fundamental I foi em escola estadual o de $5^{\mathrm{a}}$ a $8^{\mathrm{a}}$ foi numa escola da prefeitura, o ensino médio em um colégio que necessitava de vestibulinho para entrar e o curso de bacharel, licenciatura e mestrado em ensino de ciências.

Pai: filho de trabalhadores da roça, estudou até a $3^{a}$ série do ensino fundamental em Minas Gerais e, já casado e com filhos em São Paulo, estudou na indústria em que trabalhava, para terminar o ensino fundamental, fez supletivo ginasial e colegial e cursos de segurança. Ele adorava e adora até hoje contar estórias de quando era leiteiro, dos bailes na roça e das oportunidades que não pode aproveitar quando pequeno pois trabalhou desde cedo.

Lembranças da minha infância: Cantava músicas saudosas do interior e contava estórias e histórias e adorava testar os filhos com adivinhações ( $\mathrm{O}$ que é o que é...) e mostrar que fazia cálculos mentais mais rapidamente que os filhos, mesmo sem saber essa nova aritmética. Também gostava de ler (bíblia, jornal e o que aparecia em sua mão) e dizia que só com estudo podemos "crescer na vida".

Mãe: filha de portugueses que tinham um pequeno sítio no interior. Completou o ensino fundamental na infância (terminou o "grupo escolar"), era costureira tinha uma letra desenhada e era muito religiosa. Era mãe rígida mas doce, preocupada com a educação e formação dos filhos, caprichava em tudo o que fazia, ia quase todos os domingos à missa, participava de procissões e quermesses. Morreu jovem (39 anos) com câncer e sofreu por pelo menos 4 anos com essa doença, sem demonstrar desesperos, apenas preocupação com os filhos.

Lembranças da minha infância:_Ela ajudava os necessitados e me incumbia de alfabetizar algumas crianças carentes que eram pedintes na porta de casa e que não freqüentavam à escola (Eu desisti depois de perceber que não conseguia “ensiná-los a ler e escrever”)

Irmãos: Nenhum problema entre nós que não fosse normal entre irmãos. Com o falecimento da minha mãe, eu (13 anos) meu irmão (15 anos) e minha irmã (6 anos) ficamos morando em casa com meu pai e os laços familiares ficaram mais intensos. A união permanece até hoje. Todos os irmãos são dedicados no que fazem e perseverantes.

Pessoas que me influenciaram a ser professora.

Me lembro do meu pai dizendo que iria comprar uma máquina de costura para que eu fosse uma costureira como minha mãe. Isso me deixava muito irritada pois não queria ficar sentada em frente a uma máquina de costura como eu sempre a via. Dizia então que ia ser professora. Desde pequena gostava de ensinar os colegas que não entendiam a matéria.

Inicialmente a influência a ser professora foi da minha mãe, me pedindo para que ensinasse aos que não sabiam ler e escrever, a valorização ao estudo sempre enfatizada por meus pais e depois as professoras primárias que tinham uma dedicação intensa e me incentivavam.

Três professores tiveram grande influência:

Uma professora da $1^{\mathrm{a}}$ série que nos contou que o homem tinha chegado à Lua, da importância do conhecimento e que nós ainda iríamos visitar esse satélite da Terra em ônibus espaciais - Ao chegar em casa contei aos meus pais o grande feito e ouvi do meu pai que isso era mentira, que nenhum homem poderia sair da Terra e isso era invenção dos estrangeiros - foi um momento de frustração que me fez pensar pela primeira vez em contribuir para diminuir a ignorância das pessoas)

Uma professora primária que me premiou com um livro (Reinações de Narizinho de Monteiro Lobato) pela minha dedicação aos estudos - foi meu primeiro livro não didático pois até então eu só lia "Caminho Suave" e pedaços de jornal que vinham embrulhando a carne ou as bananas;

Um professor de matemática que devido a minha facilidade com essa disciplina, me colocava como sua assistente para ajudar os colegas que não compreendiam a matéria.

Não tenho dívidas para com essas pessoas, pois acredito que de uma forma ou de outra eles conseguiram me encaminhar no que acreditavam ser importante. O que ficou foi o reconhecimento pelo que fizeram 
Os meus alunos, na escola que hoje eu leciono, de um modo geral me tratam bem. Quando fazem perguntas de algo que não entenderam ou relacionado à disciplina de química e eu consigo responder ou mudar a estratégia para facilitar a compreensão, percebo que há reconhecimento do que faço através de expressões como:

Agora eu entendi!;

- Olha, a professora sabe!

- Por que você decidiu escolher química? Tem muita coisa pra saber.

Nas conversas com os alunos, quando sabem que minha opção foi a educação, inclusive no curso de pós-graduação, existem duas correntes de idéias: os que perguntam se vale a pena ? (eu digo que é o que eu gosto de fazer) e os que querem saber que tipo de pesquisa existe em educação.

$\mathrm{O}$ reconhecimento maior ocorre quando percebo que os alunos aplicam alguns conceitos aprendidos em situações cotidianas e eles me contam que conseguiram explicar (está ficando cada vez mais raro).

Gostaria de influenciar os alunos a serem curiosos, a valorizarem o conhecimento, seja ele qual for e a "ganharem tempo" estudando, sem esse pragmatismo (pra que serve isso?)

As Coisas que mais me chateiam na sala de aula: são a falta de respeito com colegas e com o professor, apatia, falta de empenho e frases do tipo: Em que isso vai ser importante na minha vida?

O que mais gosto na sala de aula: interesse, perguntas sobre o conteúdo que está sendo abordado e que vão além dele, tentativa de uns em ensinarem aos outros quando o conceito não foi entendido e sugestões de experimentos ou pedido de experimentos sobre o assunto que estamos estudando. Minha maior preocupação é com a falta de interesse dos alunos com o conhecimento, com a dificuldade cognitiva de alguns e com o uso de drogas em idades cada vez menores.

No conselho de classe, por mais democrática que seja a escola, sempre ocorre uma "forçada de barra" por coordenadores ou diretores, para aprovar ou reprovar determinado aluno. No entanto, nas escolas nas quais eu já trabalhei ou trabalho, nós professores apresentamos dados sobre o aluno e opinamos (enquanto disciplina e área) se o estudante tem condições de acompanhar a série seguinte ou não. As discussões podem levar até mais de 1 hora em um caso de provável reprovação (a escola é pequena).Ao final a decisão ocorre por votação.

Quando percebo que, nitidamente há uma argumentação em favor desse ou daquele aluno por motivos pessoais (amizade com a família ou para diminuir as polêmicas), me irrito muito. Tenho tido algumas surpresas com alunos nos quais eu votei contra a maioria para reprová-los ou promovê-los. Às vezes o aluno reprovado se empenha muito mais no ano seguinte e, às vezes era o que faltava para ele largar tudo. 
ANEXO 6: História de Vida João

\section{Todos os nomes de pessoas, locais e instituições foram trocados para preservar a identidade do pesquisado.}

A esta altura do campeonato, não procurei ainda me lembrar ou me preocupar com o que passei em minha vida, se isso foi e como foi essencial na escolha da minha profissão e no amor que tenho hoje por ela. A entrada no programa de pós-graduação da universidade tem muito a ver com este amor, mas também tem a ver com a falta de amor que tenho observado em alguns professores. Como o amor pode ser útil na aprendizagem?Resp- $\mathrm{O}$ amor faz as pessoas acreditarem em um objetivo e lutarem por ele com mais garra. Eu faço mestrado em ensino de Física porque acredito que posso dar a minha contribuição, pelo menos, onde trabalho. Por isso, faço o impossível para que o meu amor pelo trabalho que eu faço não se acabe. Isso desde que eu me dei conta do que eu estava fazendo na escola, de qual era o meu papel como aluno. Até hoje eu tento ser o professor que eu nunca tive nos anos básicos da escola, até completar o ensino médio. Tanto que minha vida ficou até um pouco vazia, e decidi voltar e fazer o ensino médio novamente. Esta volta ao passado me traz várias lembranças que, se fosse listar todas, não haveria tempo hábil o suficiente para tal. São muitos aspectos que levam em consideração problemas, mudanças e alterações na minha vida pessoal, os quais irei relatar alguns mais importantes e que são pertinentes a este memorial.

\section{A conturbada pré-escola e meu primeiro ciclo do ensino fundamental:}

Há coisas que ainda me lembro destas épocas, porém, muito vagas na memória. O que me lembro muito bem é das minhas professoras do pré: Elô e Dinah. Estas duas pessoas foram, sem sombra de dúvidas, as professoras que mais acreditaram que eu tinha um papel muito importante na sociedade. Isso elas falavam para todos os seus alunos, sem exceção, mas me pareceu que era diretamente pra mim que elas falavam.

Muitas vezes eu era chamado para recitar poemas e peças, onde eu tinha que decorar coisas, e eu o fazia muito bem, até que minha mãe apareceu na história. Até então eu não vivia com a minha mãe, mas sim com meus avós e tios. Minha mãe me deixara com três meses de idade e, mesmo a conhecendo, nunca se mostrou entusiasmada para morar comigo. Mesmo porque ela não tinha condições financeiras para tal.

No último ano do pré, eu tive muitas dificuldades em me sair bem na escola. Não tinha mais aquele entusiasmo pelo aprendizado, pois sabia que, mais cedo ou mais tarde, eu seria tirado do bairro em que eu havia crescido, dos meus amigos, dos meus familiares, etc.

Isso, não aconteceu, pelo menos nos dois anos seguintes. Fui para a primeira série com sete anos em uma escola pública, chamada Dona Sueli, na noroeste de São Paulo. Reencontrei ali vários colegas que haviam deixado a mesma escola que eu. Conheci a nova professora (ou deveria chamar repressora), a dona Laura.

Esta foi totalmente o oposto das primeiras, pois foi a primeira professora que eu tive que ensinava literalmente "na marra". Ela era extremamente severa, nós estávamos saindo da ditadura, mas ela ainda permanecia lá. Minha orelha queimava, pelo menos, duas vezes por semana por causa da minha letra (que nunca foi assim um primor) e da matemática. Me lembro de ter levado duas pancadas de palmatórias na mão: uma por causa da matemática e outra por causa de um beijo que eu dei em uma menina: Ariana. Apanhei de novo da minha avó, pelo mesmo motivo. Quando começou o segundo ano, pensei que havia acabado tudo, mas peguei a Dona Laura novamente como professora. Que lástima!!! Apanhei o ano inteiro novamente e não me lembro de ter aprendido nada que trouxe para cá. No ano seguinte aconteceu o que eu já não estava mais esperando: minha mãe me levou para morar com ela no Tatuapé. Nesta época houve uma briga feia dela com minha avó. Eu não entendia por que, mas, no entanto, fui com a minha mãe para lá. Na nova escola, conheci outra professora carrasca: Dona Aida. Ela com a minha mãe faziam um par perfeito: eu apanhava da professora na escola e da minha mãe em casa. Culpa de quem? Maldita matemática.

Aprendi a tabuada na pancada. Até hoje eu me lembro do 8 × $8=64$. Minha mão dizia que era um número graaaaaaannnnnnnde e cada vez que ela fazia isso, uma das mãos dela vinha em direção ao meu rosto. E ai de mim se eu desviasse: eram duas pancadas que eu levava. Assim foi passando minha terceira e quarta séries, havia ganhado novos e poucos amigos, mais muito sinceros. Amigos que eu 
não vi mais no ano seguinte, pois tive que me mudar novamente: a situação financeira não estava nada bem, voltando a vê-los em 1999, já na universidade.

\section{Segundo ciclo do ensino fundamental:}

Nova mudança de escola, nova adaptação. A essa altura eu já estava acostumado, mas desta vez, não teria mais que agüentar um professor só. Seriam 8 . O medo de ter professores iguais àqueles que tive me deixavam de cabelo em pé. Mas, daí, tudo se encaminhou muito bem até a oitava série.

Meu medo de matemática acabou, com a vinda de uma professora que foi diretamente essencial na minha formação. A professora Rosa foi quem realmente me ensinou matemática de uma forma muito mais prazerosa que as professoras que eu havia tido anteriormente. Ela era paciente, carinhosa, amável e tinha uma maneira de ensinar muito mais eficaz. Hoje sinto um prazer enorme em trabalhar com ela na mesma escola.

Vários outros professores vieram depois disso. Mas uma pessoa que me ajudou na escolha desta profissão foi uma professora de Educação Artística que tive, a professora Eliana. Esta era uma professora que realmente gostava daquilo que fazia. Era a professora que cuidava de seus alunos como se fossem seus próprios filhos, via a arte e nos fazia raciocinar com ela de uma forma que não encontrei em ninguém.

Mais tarde, quando eu entrei na Universidade, ela foi a única pessoa dessa época que me cumprimentou, dizendo que já sabia que eu me daria bem em qualquer coisa que eu escolhesse na vida.

Não me lembro de muitas coisas que aconteceram nesta época, mas alguns flashes me fazem recordar alguns professores em que suas aulas passavam muito depressa. Entre esses estão a professora de Ciências, , a primeira professora que me levou para um laboratório, a professora de História, Dona Batkombi (Não é a avó do Batman, embora o nome lembre algo parecido). Esta era uma professora de 70 anos, Russa erradicada no Brasil desde 1940, quando veio fugida da $2^{a}$ Guerra com a família. Estava aposentada, mas mesmo assim não parou de lecionar. Esta era uma aula que eu sempre queria que terminasse logo por dois motivos: ninguém a respeitava por causa de sua idade, a professora já estava até meio esclerosada, e o outro motivo é que a aula dela era sempre a mesma coisa: uma bateria de cerca de 100 questões que ela fazia e ela mesma respondia. Não aprendi nada de História.

E um dos professores dos quais me lembro era o professor Silvio, de Língua Portuguesa. Este, para chamar um pouco a atenção dos alunos subia até na mesa e até rebolava. Ele era divertido e ensinava bem. Suas aulas passavam muito rápido.

Esta parte da minha vida deu uma outra virada: tinha 14 anos, uma irmã de um ano de idade, a qual eu cuidei desde os três meses, quando minha mãe a deixou em casa e sumiu. Ninguém sabia onde ela estava e eu decidi não esperar mais por ela. Levava minha irmã na creche de manhã, ia para a escola, da escola ia trabalhar à tarde e ficava no trabalho até as 22:00 h. Morava com minha avó e com meus tios, que cuidavam também de minha irmã.

\section{Ensino médio I e II: minha destruicão e minha recriacão.}

Sei que este título parece uma coisa meio fúnebre e meio confusa, mas foi assim que eu me senti no ensino médio. Fiz duas vezes o ensino médio, dois cursos técnicos, um de administração de empresas, o qual terminei em 1993 e um de contabilidade básica, que terminei em 1997, quando entrei na Universidade.

De 1991 à 1993 fiz um curso de administração de empresas bem básico, onde a maioria dos meus professores não conseguiam nos fazer aprender muito bem. Minha formação não foi puxada para o lado do raciocínio (só fui aprender a raciocinar direito em 1995, quando voltei à escola para fazer novamente o ensino médio), portanto tinha muitas dificuldades em aprender.

Nesta época eu comecei a fazer um estágio em um banco. Este estágio durou dois anos e me rendeu um aprendizado muito maior do que o que tive na escola. Nenhum dos meus professores soube ser convincente naquilo que fazia. Sem contar que depois eu fiquei sabendo que alguns destes professores estavam lecionando a matéria que eles não tinham formação. Você acha que fazia diferença o fato de eles terem formação ou não?

Resp- Claro! Eu percebia que muitos deles não ficavam muito seguros daquilo que eles estavam passando. Não só eu, mas os meus colegas de classe também. Isso acabava desqualificando os professores.

Este foi o caso de um professor de estatística básica que tive neste curso. Só depois que eu soube que ele era mestre em Biologia. Me perguntei: "o que ele está tentando fazer ao dar aula de estatística?". 
Para mim aquilo era uma grande perda de tempo de uma pessoa que fez um mestrado, defendeu uma tese e estava dando aulas no Estado. Que ironia!!! Olha eu aqui na mesma situação...

Me formei em 1993 e, agora com um diploma nas mãos, o que seria da minha vida??? Minha mãe havia me deixado novamente; estava morando com meus tios, mas com a perspectiva de arrumar um emprego na área de administração.

Doce ilusão!!! Todas as empresas que eu visitava queriam pessoas que já tivessem pelo menos, um ano de experiência. Eu tinha dois, mas no estágio, mais nada. Veio a idade de me alistar no exército, o que esvaiu todas as esperança que tinha de arrumar um emprego na área.

Isso foi 1994, ano de eleição para governador do Estado de São Paulo. Então eu comecei a trabalhar para um partido político, colando cartazes nos postes à noite. Como foi a única coisa que eu tinha achado para mim, entrei de cabeça neste emprego.

Neste meio tempo, a biblioteca era um dos meus refúgios preferidos. Quando percebi que já tinha lido todos os livros pelos quais eu me interessava, tive uma idéia: voltar a estudar. Mas eu já tinha terminado o colegial, como eu poderia estudar novamente? Não tinha dinheiro para fazer um curso pago, tampouco para enfrentar uma faculdade. Então, resolvi enfrentar a outra opção de curso que tínhamos na escola que eu havia estudado: a contabilidade geral básica.

Em 1995 comecei a estudar novamente. Muitos professores que já haviam me dado aulas no curso de administração de empresas me falavam "O que você está fazendo aqui de novo? Isso não é mais pra você. Procure fazer outra coisa." Ou então "Enchendo o saco de novo aqui? Vai procurar sua turma!!!”.

Mas, o que estas pessoas não sabiam é que eu estava dando o passo mais decisivo da minha vida. Foi aí onde eu conheci os cinco professores que mais me apoiaram na empreita de prestar um vestibular, além dos colegas que me fizeram crescer como cidadão. Nesta época houve uma pessoa que estava pensando em montar um Grêmio estudantil.

Me juntei com essa pessoa, contactamos uma entidade estudantil e arrumamos uma grande e barulhenta briga com os diretores da escola. Estes eram severos e extremamente tradicionais no modo de dirigir. Eram verdadeiros ditadores e nós tivemos muitos problemas para fazer com que eles nos deixassem fazer algumas coisas, como arrumar a biblioteca da escola (que nós só conseguimos com a ajuda desses cinco professores), arrecadar livros para essa biblioteca e fazer um grupo de estudos aos sábados, para que algumas pessoas pudessem entrar na Universidade.

Com muito custo nós conseguimos que a direção da escola nos deixasse fazer o grupo de estudos aos sábados. Para isso, um destes cinco professores, Francisco de História, teve que se candidatar para o cargo de coordenador pedagógico e fazer um projeto, homologar este projeto na DE e mandar para a secretaria da Educação. Este projeto foi o maior responsável por eu ter entrado no Instituto de Física. Este professor foi o maior responsável por eu ter entrado em um curso universitário. Como qualquer aluno de escola pública eu não acreditava que poderia entrar em uma universidade. Mas este professor, juntamente com um professor de Física da escola, Luis, me convenceram que eu poderia tentar, pelo menos, entrar em uma universidade. Estes professores foram a minha maior inspiração para tentar, já que eu não tinha nenhum apoio da minha própria família.

Sempre admirei estes professores. Os dois hoje são mestres em ensino de Física. Hoje nós trabalhamos juntos na mesma escola que ele me deu aula. Estas foram as pessoas que me inspiraram a fazer um curso de licenciatura. Os dois lecionavam com muita dedicação. Eu acompanhei diversas vezes os dois preparando aulas e gostei do negócio.

Nunca gostei de história na minha vida. Tive diversos professores que eu achava ruins, não tive vontade de aprender com eles. Os outros professores eram muito bons, na medida em que a classe deixava, mas os de história deixavam a desejar. Mas o Francisco não. Este professor era diferente. Ele ensinava com gosto. Não era o gosto pela escola, mas sim pelos alunos e foi isso que me fez gostar do seu jeito de lecionar. Foi a primeira vez que eu aprendi história decentemente.

O Luis também tinha o seu diferencial, apesar de eu não conseguir entender nada de física que ele me ensinava. Não é à toa que eu prestei para química na primeira vez. Mas, depois do primeiro ano que eu prestei o vestibular (e não passei), fui me aproximando mais da Física. Por causa do grupo de estudos aos sábados, tinha que apresentar todo o sábado um assunto diferente, relacionado com a matéria do vestibular e gostei muito da parte de Física e de Biologia. Todas as vezes que eu tinha que apresentar um assunto no grupo, escolhia um desses assuntos para apresentar. 
Neste ano, o Luis que era tecnólogo na sua formação, entrou na universidade para fazer um curso de Licenciatura. Segundo alunos amigos meus que estavam tendo aula com ele, ele estava melhorando muito seu método de ensino. Por isso eu me empolguei mais ainda para fazer um curso de licenciatura e estudei bastante para isso.

Enquanto eu estudava, muitas outras pessoas entravam em universidades públicas e privadas por meio do grupo de estudos. Até eu passei em faculdades privadas, mas eu queria entrar na universidade pública. Não era meu sonho, mas era questão de honra fazer um curso em uma universidade pública, uma vez que eu não poderia pagar uma faculdade para mim.

Prestei ainda este ano mas não passei. Entrei na USP para fazer o curso de licenciatura em Física, mas o grupo de estudos deu frutos para mim. Neste ano que eu estava terminando o meu segundo curso de ensino médio técnico eu passei na UNICAMP para o curso de química, na UNESP para o curso de Biologia e na FATEC para o curso de Edificações. Escolhi na USP porque ela era mais perto da minha casa e estou aqui desde então.

Minha formação foi um misto de espelho dos meus antigos professores e agora amigos. Hoje sou um professor de Física que acredita nos meus alunos e não deixo que nenhum deles caia na besteira de não acreditar que são capazes de fazer um curso na USP ou em qualquer faculdade pública. É muito provável que uma das minhas alunas de suplência preste vestibular, pois eu e outros professores estamos incentivando e ajudando muito esta menina.

O que ser professor significa para você?

Pergunta muito difícil de responder. Talvez signifique estar com a vida de muitas pessoas em suas mãos, Se você for um bom professor, seus alunos podem estar sendo encaminhados para um lado que poderá deixa-lo em boas condições.

Fale sobre o seu curso universitário

Bem atribulado. Eu não morava em um lugar que me propiciasse a estudar. Todos os meus vizinhos tinham problemas com drogas e o ambiente da minha casa não era legal para estudar. Muito barulhento. Tïve que trabalhar logo no primeiro ano do curso. No segundo fui morar sozinho e no terceiro, me casei. Meu curso, que era para demorar quatro anos, demorou cinco e meio, porque muitas vezes eu tinha que deixar as disciplinas pela metade por não poder recusar algum trabalho e era reprovado. Mas com um pouco de esforço eu consegui. Afinal, como diz um amigo meu "a vida é dura pra quem é mole...".

Sobre as aulas de química/ fisica e biologia no seu tempo de aluno, quais as suaslembranças?

Quase nenhuma. Eu não tive muitos professores de química nem de física, porque fiz dois cursos profissionalizantes que não tinham nada a ver com ciência ou com educação. A única coisa que me lembro é que um dos meus professores de Física não era capacitado para lecionar Física. Tanto que ele não sabia me tirar nenhuma dúvida de qualquer parte da Física que não tinha a ver com o que ele tinha dado. Digo isso porque eu já havia tentado tirar dúvidas com ele.

Como era seu desempenho nas avaliações?

Bom, na medida do possível. Tinha uma auto-estima muito baixa naquela época, o que me fazia não estudar, levado pelo que a maioria dos meus colegas falavam: "estou muito cansado e não tenho pique para estudar quando chego em casa" (Mal sabia eu que dentro de uns quatro anos eu não iria dormir mais do que quatro horas por noite...)

Você ensinava seus colegas de escola?

Sim. Principalmente depois de estar estudando para o vestibular. Acho que foi por isso que eu escolhi ser professor.

Fale um pouco sobre a sua participação em sala e dos seus colegas de grupo.

Eu considero a minha atuação dentro da sala de aula boa, na medida do possível. Poderia ter sido

melhor, mas é que marcaram minhas reuniões pedagógicas para as terças-feiras e eu estou tendo que sair mais cedo. Por isso, acho que minha atuação poderia ser melhor. Meus colegas são maravilhosos. Cada um traz uma experiência de vida diferente, trabalham em lugares e em condições diferentes e, ainda assim, acham ânimo para tentar melhorar cada vez mais.

Como seus avós viam a sua escolarização? Eles te ajudavam? 
Minha avó teve um papel fundamental na minha criação, mas não na minha educação, a não ser pelas revistas de romance que ela lia e, não tendo nada pra fazer, eu lia também. O que me deixou um rapaz muito romântico até os 17 anos. Depois eu caí na real e vi que nada na vida (pelo menos na minha) era romântico. 
ANEXO 7: entrevista Madalena

Todos os nomes de pessoas, locais e instituições foram trocados para preservar a identidade do pesquisado.

\section{MADALENA 44 ANOS PROFESSORA DE QUÍMICA HÁ 20 ANOS 1.Você se considera uma professora? Por quê?}

Me considero. Porque eu acho que professor tem a função de transmitir conhecimento e fazer com que esse conhecimento seja apreendido, eu acho que alguns momentos eu consigo isso, eu não consigo $100 \%$, mas eu vejo que todos os professores dizem que não conseguem $100 \%$, né? Eu sou professora porque eu transmito um conhecimento que de alguma forma ele é apreendido é captado e ele colabora de alguma forma na vida daquele aluno. Então eu me considero professora.

\section{Qualquer pessoa pode ser professor? Por quê?}

Eu acho que não porque é assim, eu já vi pessoas que tem uma grande quantidade de conhecimentos para transmitir mas não tem tolerância com a ausência de conhecimento do outro, né. Tem professor que fala assim...cara burro, né, como ele não entende o que eu estou falando? Eu acho que tem pessoas que são assim, elas tem o conhecimento mas quando elas vão transmitir têm uma impaciência com a forma como essa pessoa assimila aquilo, ela acha que tem um caminho a ser seguido, então não tem muito jeito para explicar, explica daquele jeito, entendeu? Não entendeu? Então você é burro e não adianta e eu acho assim que o professor tem que ter paciência tolerância e tem que admitir de que nem todos aprendem pelo mesmo caminho, tem que ficar sempre procurando alternativas para ficar mais claro aquilo que você quer transmitir e que quanto mais você ensina mais você descobre que tem que ter um outro caminho ainda, cada ano que passa, você fala bom..talvez isso possa ser explicado dessa outra forma e atingir uma maior parte..mais pessoas, né porque as vezes agente não atinge aquilo que eu falei inicialmente, não atinge $100 \%$ então você esta sempre procurando caminhos em que você pode ensinar mais, e que a pessoa consiga captar aquilo e usar aquilo de alguma forma, então aquele cara que não é tolerante com a falta de conhecimento do outro ele é um cara que não pode ser professor.

\section{Que atributos distinguem a profissão docente das demais?}

O professor ele está preocupado com o ser humano, ele não, não esta preocupado em produzir alguma coisa como na industria que eu já trabalhei. Qual é sua função? Sua função é exercer uma tarefa e essa tarefa vai gerar...um produto alguma coisa assim..e ao ser professor você está preocupado com o ser humano, quer dizer ..esse conhecimento que utilidade vai ter para as pessoas com as quais eu estou falando? Esse conhecimento de que forma vai colaborar com o ser humano, o que vai colaborar com a vida dele, eu acho que a questão do humano, eu acho que o professor tem que ser generoso, generoso quer dizer dividir tudo aquilo que ele sabe, e isso não acontece por exemplo em outras áreas tradicionais . A história do partilhar o conhecimento, eu já trabalhei assim quando o conhecimento é a garantia que ele (professor) tem para a permanência num determinado lugar, num determinado posto, o professor ele estuda para ensinar e vai procurando sempre outros caminhos para passar aquele conhecimento, então eu acho que é aquela generosidade, né . Embora a gente as vezes encontra alguns professores que retém algum conhecimento, você já deve ter visto , professor que não cede a aula dele , né ..por algum receio aí tal. Mas acho que de um modo geral é essa diferença...é.. você está lidando com pessoas para construir alguma coisa que não é um bem material você está tentando colaborar para a construção de um ser humano, e o conteúdo no meu caso, químico é uma mera desculpa para você inserir algumas coisas, né, e..então eu acho que é isso, o caráter humano, o caráter generoso, você não retém a informação muito pelo contrário você quer que essa informação seja transmitida da forma mais clara possível e esta sempre procurando outras formas que sejam mais claras. Nas outras profissões nas outras, é exatamente o contrário essa generosidade não existe e o poder se estabelece em reter o conhecimento.

\section{Você consegue tecer uma linha lógica falando sobre os motivos que te levaram a ser} professora?

Eu acho que é assim... a priori eu fui influenciada ...não foi assim ó...eu trabalhei na industria não gostei né...embora em termos salariais era bastante interessante , mas eu não gostei exatamente da ausência do caráter humano né, então você descobre uma determinada coisa você tem que tomar muito 
cuidado porque as pessoas vão tentar de alguma forma te derrubar porque com esses conhecimentos você vai de alguma forma se sobressair e passar do cargo de chefia para gerência e tal é bem isso mesmo, na indústria a felicidade do outro é estourar champanhe na sua cara, né!.. eu não gostei desse ambiente porque você fica muito tempo preso produzindo exatamente aquilo pra alguém e...colaborando com uma exploração, é assim que eu me via, aí eu comecei a dar aulas e..comecei a ter relacionamento com alunos que tem todos problemas de relacionamento humano, mas você esta lidando com pessoas é... e se você e o aluno se entendem, vocês estabelecem uma relação de simbiose de interesse . Comecei a trabalhar na industria não gostei, comecei a trabalhar como professora, porque a priori eu tinha minha filha e eu queria cuidar dela e comecei a dar aula. E aí eu descobri que nessa profissão não seria como era na indústria , existia um caráter humano, existia um partilhar e eu achei isso muito legal, eu me sentia importante, me sentia gente, colaborando de alguma forma o que eu não sentia na indústria $\mathrm{Na}$ industria eu tava lá pra ganhar dinheiro e ajudar alguém a ganhar dinheiro também, na escola eu sentia que eu tinha importância e que eu estava fazendo alguma coisa por esse aluno. Aí eu comecei na escola pública, ai tinha o problema de demorar o salário pra chegar, não era por causa dos alunos não, a questão era de subsistência mesmo , aí eu comecei a dar a aula na escola técnica achei muito interessante porque tinha a ver com a minha área de conhecimento e aí você via o resultado do seu conhecimento muito claramente você estava formando um profissional, esse profissional ia usar esse conhecimento pra produzir lá a escolha que ele fizesse, pode até ser que ele fizesse escolha de ir para a industria, mas ele tinha um interesse muito grande pelo conhecimento químico. Aí depois eu acabei indo para o cursinho que era um desafio mesmo, era completamente diferente e no cursinho esse conhecimento químico tem uma função muito clara que é para o vestibular, então eu passei a adaptar esse conhecimento , o conhecimento como é que eu poderia distribuí-lo da forma mais eficiente possível para atingir o objetivo daquele ser humano que era chegar ao vestibular e entrar na faculdade. Aí eu descobri os caminhos e (pude) ser clara o suficiente pra fazer ele se dar bem na prova de química e fazer a profissão que ele quisesse. Depois acabei dando aulas na faculdade que eu gosto bastante. Eu acho eu é isso da indústria eu não gostava pela da falta de humanidade, fui dar aula por uma situação que era minha filha e percebi que na escola eu teria uma relação humana, né mais interessante mais produtiva pros meus anseios enquanto pessoa, o resto né eu acho que é só desafio você muda de setor né, você vai fazer o que com esse conhecimento você vai simplificar ele ao máximo e transformá-lo em algo digerível para qualquer caso, independente da profissão que ele (aluno) queira você vai transformá-lo muito purificado para um cara que está fazendo química mesmo, ou você vai trabalhar com o conhecimento mais generalizado usando a química como mera..isso não tem importância, né fiquei nisso ai e continuei nesse cainho em função do caráter humanizado.

\section{Você conhece algum professor que não deveria ser professor?}

Vários são os professores que normalmente assim.., ele quer completar a renda e aí ele tem essa intolerância que eu falei inicialmente, né, sempre o aluno é bobo, sempre o aluno é incompetente e a culpa não é dele ..é diz que é impossível dar aulas pra esses caras e você não vê o cara repensando sua própria postura, ele não deveria estar ali, mas ele está porque dá um troquinho a mais e ele completa a renda dele. Aquele cara não deveria ser professor porque ele está esquecendo que aquilo ali é um ser humano e que ele não está colaborando e de alguma forma passando a idéia de que essa profissão é só mesmo um quebra galho. Uma graninha a mais, ele esquece que tem gente envolvida nisso.

\section{O que seus pais acharam de ter um filho professor?}

Meu pai não teve oportunidade de presenciar isso, meu pai faleceu antes, mas a minha mãe achava que eu ia morrer de fome, ela achava que eu devia continuar na industria, minha mãe sempre foi muito materialista. Então ..até hoje ela tem vergonha de dizer que eu sou professora, o que ela fala então que ela é? Ela é engenheira química, ela é química, eu já expliquei pra ela $\mathrm{n}$ vezes, mas ela se constrange em dizer que eu sou professora como se fosse uma coisa menor.

\section{Quais as lembranças mais marcantes do seu período de escola?}

Então eu estudei no primeiro grau, no ensino fundamental e tinha professores que ás vezes davam castigos, castigos físicos tal, e essa é a lembrança que mais me incomoda. Embora eu não tenha sido castigada sempre tive medo de seré, o professor rasgou a orelha de um aluno, eles colocavam milho, colocavam atrás da lousa, davam réguada, essas coisas que parecem que não existem mais, mas que existe ,né. 
E acho que isso me retraiu muito enquanto pessoa na relação social entendeu? Você fica com muito medo, você vai pra escola, seu pai diz que você tem que ir pra escola, né, você não tem que quem socorra você porque na mentalidade deles a função do professor também é essa mesmo castigar, exercer castigo físico mesmo e aí você se sente muito solitária, né, você está a mercê de uma pessoa que hoje eu sei que é insana, quer dizer que bate que tortura, que existe uma tortura atrás disso essa é a imagem que eu tenho. É de uma solidão muito grande, né, porque assim eu passei a ficar cada vez mais retraída eu era uma menina típica de mato mesmo, né, fazia muito caminhada, pensava muito, sempre fiquei muito sozinha, sempre pensei muito e observar isso (as punições) fez com eu me mantivesse no meu lugar assim por medo de ser punida, de sofrer aquilo que eu via os outros sofrerem, né. Isso aconteceu no ensino fundamental, depois eu vim pra São Paulo e no meio do ano, então foi completamente diferente essas punições não existiam, mas eu não tinha amigos porque eu estava chegando, aí eu acho que eu acabei ficando na mesma escola da 5.a a 8.a aí no 1.o. (colegial) eu fiz numa escola de manhã ,agora o 2.o. e o 3.o. eu fiz à noite .Então é isso que eu vi na (escola) da minha filha e que eu achei fantástico, porque ela pegou uma escola do 1.o até 3.o. colegial com os mesmos amigos, e eu conheço os meninos desde pirralhinhos desde os 7 anos, né , e ela criou um circulo de amigos e tal e essas mutações essas mudanças que meu pai fazia muito procurando melhorar a vida eu não tive muito acesso (a amigos). Então eu começo numa escola muito repressora, depois eu vou para uma escola que eu não conheço ninguém, não sei se aquilo vai se repetir e quando vou me achar eu comecei a trabalhar, né ,eu nunca consegui estabelecer assim um grupo de amigos da escola, porque fiquei mudando muito de uma situação para outra.

\section{Como foi o seu primeiro dia de aula como professora?}

Foi na escola pública, a noite, né e estava super nervosa né, a gente sempre acha que é o conteúdo tem que estar muito afininadinho e tal né, mas eu peguei uma turma, acho que eu dei sorte, peguei uma turma legal e naquele dia eu descobri, eu abri o jogo é o meu primeiro dia de aula e eu disse: eu estou super nervosa , se eu falar alguma coisa que vocês não entendam por favor perguntem e tal , e aí eles foram muito solidários com o meu nervoso, sabe de um modo geral e a medida que a aula foi transcorrendo eu fui ficando calma e aí você o conteúdo vai fluindo mais, mas eu acho que é assim sempre as primeiras aulas que você dá, o primeiro ano, a sua essência a sua preocupação central é o conteúdo que na verdade você não domina né , e porque quando você dá aula no ensino médio você tem que ter mais ou menos uma visão geral, você começa a aprender de pedacinho aí você começa a fazer as pontes, né,. Agora se você dá aula por exemplo no $1^{\circ}, 2^{\circ}$ e. $.3^{\circ}$. colegiais naquele mesmo ano, só depois de um semestre é que você vai começando a ter uma visão da química como um todo, no primeiro ano você percebe que o babado não é o conteúdo não ,que o negócio é você olhar no olho do aluno , essa interação,né... que o conteúdo, claro você tem que ter um domínio, eu acho que esse período de um ano ele é interessante, mas você vai aprendendo também durante esse um ano que você precisa que o aluno esteja com você senão você se sente a lousa, né, não é essa intenção, não é por isso que eu fui trabalhar como professora, eu fui trabalhar como professora por causa do caráter humano, o caráter humano significa ter interação, se você vai lá escreve na lousa e o cara copia e você ao interagir com esse cara e não fica sabendo se ele entendeu se ele não entendeu se ele gostou se ele não gostou, você é um livro,né, por isso não precisa de você, então você dá um livro pro cara, fala o capítulo e vai embora, né.

Então acho que foi isso, assim... o marcante foi o fato de eu ter aberto o jogo com eles e dito gente é o meu primeiro dia, to nervosa, se eu falar alguma besteira pode reclamar abri meu coração mesmo, e essa postura foi interessante porque eu passei mais ou menos a adotar isso, né é quando eu to com medo, eu to com medo e eu aviso to insegura nuca dei aula nessa turma, né, faço uma brincadeirinha se eles dão um sorriso pra mim eu me sinto em casa e aí a coisa flui normal.

\section{Relate bons e maus momentos ocorridos em sua sala de aula. Como foi sua atuação nessas} situações?

Eu posso dizer que eu tive muito mais bons momentos do que maus, bons, eu acho assim que é o dia que você dá sua aulinha e os caras estão com você , você conversa com eles, eles fazem perguntas, você pergunta para eles, eles tem respostas sejam lá quais forem, existe um tipo de interação, né, um dia que é mais difícil é quando ta chegando perto de um feriado, ta chegando perto das férias e você começa a perceber eles mais agitados, mas quando você fala alguma coisa e o cara fala puxa fala legal isso, muito gostoso a gente ouvir isso, puxa eu nunca tinha pensado nisso, nossa vou usar isso na sala de aula, vou usar isso em casa, isto é se sentir útil né, você está fazendo um trabalho, você não veio ao 
mundo exclusivamente pra ganhar seu dinheirinho, as vezes eu falo isso pros meus alunos eu não estou aqui pra ganhar um dinheirinho, eu estou aqui pra vocês atingirem os objetivos de vocês porque dinheirinho a gente ganha em qualquer lugar e não é essa a proposta. Esses são os bons momentos. Eu acho uns dois maus momentos, o primeiro foi assim... eu estava dando aula num cursinho em Santos numa sexta a noite e os caras diziam que Santos é diferente de São Paulo mas eu nunca gostei de generalizações, então eu dizia que não... eu vou conseguir dar aula pros caras e... assim tinha a turma que assistia aula e tinha a turma da sexta feira do bar e que ficava chamando o restante e dizendo oi pessoal sai daí...não é nada disso... vamos embora... e eu dando aula... e aí aconteceu o seguinte, era uma turma que agente não tinha se entendido eles estavam meio que obrigados ali, muito bravos porque eu estava insistindo em dar aula pra eles, e era pré vestibular e ai...um dia eu fui lá dar aula e .estava na apostila tal e o pessoal não tinha apostila então eu falei não tem problema eu passo os exercícios na lousa pra vocês, aí começou sair aluno um a um e aí eu pensei tudo bem..., eles vão até a secretaria e a ordem que se tinha é que durante a aula não se distribuiria a apostila, mas aí se distribuiu e aí começaram a sair todos os alunos , né, e aí eu não lembro direito um aluno ficou bravo, eu não me lembro bem qual a razão pela qual ele ficou bravo, mas eu aprendi uma coisa da psicologia da fala, essa turma não dá, essa turma eu entrava ali atrasada eu não conseguia desbloquear essa turma, aí o menino falou onde se viu dar aula daquele jeito numa sexta feira disse que eu estava dando muito conteúdo ele reclamou da forma como eu vinha dando conteúdo. Ai eu falei pra ele olha bicho é que cursinho é assim você tem os módulos você tem que cumprir até pra você chegar na época da revisão e ter o que revisar e aí ele me deu uma resposta grosseira, né , você é vagabunda, eu não me lembro o que ele falou mas foi muito grosseiro, então eu disse companheiro você sai, ele disse eu não vou sair, eu disse você vai sair e sabe porque você vai sair? Eu não vou te tirar mas eu arranjo quem te tire e aí ele pegou a carteira e jogou no tablado, aí veio o dono da escola, mas eu nunca tinha vivido aquilo. $\mathrm{O}$ que aconteceu foi que o dono disse agora ele vai sair e quem compartilha da opinião dele vai sair também e aí metade da sala saiu e aí eu me comprometi a continuar, né, eu vou dar aula para outra metade, então a boca secou, né , e eu dei aula..e eu dei aula até o fim do ano assim.... e eu vomitava antes de entrar nessa turma,era só com essa turma, mas eu dei aula até o fim do ano. Porque eu sempre acreditei assim principalmente em cursinho, que se você se assusta e pára, você nuca mais volta então eu tinha que vencer aquilo, não importa se eu ia ser demitida, se eu ia dar aula pra dois, se eu ia dar aula pra um ou dar aula pra mim mesma, mas eu ia fazer o meu papel. Acabou tudo se ajeitando mas eu acabei me demitindo de lá porque achava que..eu não estava sabendo lidar com esse descaso. Então tem professor que dizia assim você tem que levar na flauta, você faz de conta que você dá um módulo mas não dá um módulo ,os caras não querem nada, então aquilo não era o meu pedaço . E outro momento ruim foi agora com a química inorgânica e eu acho que nos dois casos se eu errei eu acho que foi pelo excesso de ética porque foi a primeira turma de bacharelado em química que eu peguei e a escola estava muito preocupada porque existia uma escola concorrente tinha aberto um curso e estava perdendo alunos para essa outra universidade, então eles tinham um medo muito grande de perder os alunos do primeiro ano que eram 120 alunos e tal..., então a gente sofria uma pressão muito grande e os alunos obviamente percebiam isso e reclamavam. Então no curso estava indo tudo bem até a primeira prova, quando chegou na primeira prova que eu acabei não deixando colar e dando questões que procediam eles se indignaram, eles acharam que a professora que estava dando o curso que (até então)era simpática, leve..., porque isso a gente acaba transportando do próprio cursinho, como é que ela tinha dado uma prova daquele tipo e aí eu fui intransigente com a relação ao meu conteúdo. Então (devido as reclamações) eu pedi demissão (mas) fiquei até o final do semestre. Então eu disse para eles ...eu sou demissionária mas vocês vão ter que me agüentar até o fim, e dei todo o conteúdo ao qual eu tinha me proposto. Agora (o que aconteceu) tanto no primeiro quanto no segundo caso a minha preocupação era com o conteúdo, né, de que eu não estava ali novamente pra ganhar um dinheirinho, eu tinha uma função ali, no caso do pré-vestibular era transmitir aquele conhecimento de química para que os alunos fossem aprovados e no caso do bacharelado que eu achava que era muito mais sério, se eles não sabiam cálculos estequiométricos eu ensinava eu não tinha essa intolerância, só que se eu ensinava eles tinham que me dar provas de que houve um aprendizado e tal, e na verdade o que estava acontecendo com a faculdade é que ela estava abrindo mão da avaliação, faz de conta que você ensina e ele faz de conta que aprende e a gente faz de conta que forma bons químicos e todo mundo fica feliz, e nesse ponto eu não consigo. E essa intransigência eu percebo que eu acabei tendo né, talvez na licenciatura essa questão do conteúdo tenha que ser mais leve porque você ensina o cara a estudar a 
pesquisar, isso também foi uma das questões de combate ali, que eu queria que eles aprendessem e eu falava pra eles se você conseguirem aprender a ler um livro científico, os termos técnicos, vocês não precisam mais de mim vocês podem aprender qualquer coisa, polímeros, inorgânica, mas vocês precisam aprender essa linguagem. Uma das coisas que a gente se debateu foi que fiz um questionário e eles queriam que eu desse a resposta eles não se viam em condições de procurar porque a prova estava por chegar. Esse foi muito menos, muito menos traumático do que o outro porque nesse eu ainda consegui ter o humor de chegar assim para a turma e dizer assim: Vocês vão pedir pra me mandar embora? Não dá, eu já pedi demissão, né? Então vocês vão ter que aprender e não fiquei como eu fiquei com aquela turma (do cursinho) que era (meu Deus!) de vomitar, de passar mal antes de entrar em sala.. Rejeição também, né! eu acho que isso também tem a ver, embora você encontre várias justificativas para aquela situação ruim ter acontecido no fundo você se sente de alguma forma culpado e no fundo você se sente de alguma forma profundamente rejeitado, isso incomoda, só que dessa vez eu consegui trabalhar isso de uma maneira muito suave fui até o fim do ano, não tive ulcera não passei mal e acabei dando o curso, né? Só que também nessa turma não era tão unânime como foi na outra a rejeição, né, essa era assim tinha uns focos eram os lideres que conseguiram carregar alguns mas a maioria ficou comigo, lá não, foi exatamente ao contrário eu fiquei com a minoria no cursinho, né! e a maioria ficou na rua, talvez tenha sido mais traumático né, são os momentos ruins. Agora são dois contra um montão.

\section{O que te torna professora?}

Eu acho que a generosidade, a vontade de ser generosa e ser generosa não é uma questão de ser vista como generosa, porque isso que eu acho que é importante, é uma qualidade que eu quero cultivar em mim. Eu quero uma profissão que me permita ser generosa, porque eu acho que ser generoso é ser um ser humano melhor. As minhas maiores questões são de cunho interno. O que é que eu estou fazendo aqui? Pra que eu estou aqui e o que é que eu vou construir aqui? Então, ser professor pra mim o que me torna professor é porque eu posso praticar a generosidade e eu cultivo essa generosidade e eu acho que com isso me torno um ser humano melhor. Entendeu? Então eu aprendo para distribuir e é isso que me torna professora, é essa vontade de fazer o conhecimento circular e transformar em algo interessante pra quem quer que seja.

\section{O que te mantém professora?}

É essa relação com o aluno em que você aprende muito, né! É historias..., eu tive uma aluna que sofreu um acidente seríssimo, uma menina linda eu nunca vou esquecer isso, ela estava fazendo cursinho, aquelas meninas de fechar comércio, sofreu um acidente muito sério perdeu parte da voz, perdeu a locomoção de um dos lados do corpo e essa menina voltou com seqüelas sabe? Ela voltou e terminou o ano e foi para a faculdade é...conheci um outro que tinha uma doença muito grave, não me lembro exatamente ...ele tinha um vírus que estava acabando com o sistema central dele e mesmo assim o cara estava estudando para fazer uma segunda faculdade. É o sorriso do cara, é o dia em que eu estou dando uma aulinha e eu estou legal e os caras estão legais comigo e a gente está num ambiente gostoso, sabe? Eu não sou nenhuma autoridade e com adolescente eu aprendo com eles está alegria do viver essa super energia essa rapidez de raciocínio que eles tem para fazer uma graça, né. Eu vejo os caras da particular, a luta deles o que eles fazem pra conseguir um diploma e então o que me mantém é essa relação humana é esse aluno que de alguma forma me devolve muita coisa, é o abraço dele, é o sorriso dele, é ele quere tirar foto comigo, é....as vezes você está no metrô e o cara fala. Ô professora eu entrei na faculdade, obrigada. E você fala obrigada porque? Então você virou arquiteto o que eu tenho a ver com isso? Não, você me ajudou. Eu não estou aqui por nada, eu não estou aqui à toa, eu não estou aqui pra ficar enlouquecida eu estou aqui pra construir alguma coisa

O professor que eu sou - Olha! Como é que eu me vejo, né? Eu me vejo assim, uma pessoa extremamente responsável, preocupadíssima com o que eu estou falando, se o que eu estou falando está certo mesmo, né, preocupada se ele está aprendendo, eu me culpo demais, é muito difícil eu achar que a classe é uma porcaria, né, eu posso até falar isso mas quando eu vou voltando pra casa, eu falo: onde é que eu estou errando? Eu sou muito preocupada com o conteúdo e sou muito preocupada com assimilação, né? Eu acho que eu sou muito séria, às vezes até intransigente com algumas coisas, porque sou muito perfeccionista com a minha função, entendeu? Parece que eu salvo ou não salvo o mundo. Sabe assim... Exagerado. Eu preciso ser a melhor professora eu preciso transmitir tudo eu não fico conformada com o mais ou menos e eu acho que essa aí sou eu, é como eu me vejo. 
O professor que dizem que eu sou- Pois é eles me vêm exatamente como essa coisa light, porque sou muito brincalhona, né! Então eles dizem que ...Ah! que delícia a gente nem percebe o que é aprender ...porque eu invento musiquinha e eu estou sempre sorrindo e eu costumo dizer que quando eu vou dar aula parece que desce um santo, tem dia que eu falo assim...acho que hoje eu não vou conseguir dar aula, né, e quando eu vejo eu estou dando aula desse jeito assim, né. Então eles não vêm assim essa preocupação, essa super preocupação que eu tenho com o meu papel enquanto profissional, fica uma coisa assim.., tanto que eles acham que não me custa absolutamente nada dar aula, é tranqüilo dar aula né!, é muito comum isso eles me vêm como uma pessoa brincalhona, bem humorada, feliz . Eles vêem tudo isso em mim né. Eu não me vejo assim né, eu acho que eu sou bem introspectiva, muito séria, muito compenetrada, muito critica e eles me vêm exatamente o contrário.

Então eu não sou muito boa com a relação humana, engraçado que eu não sou muito boa com a relação entre os professores que trabalham comigo. Eu peguei um cursinho (para dar aulas) que é um meio profundamente preconceituoso com a mulher principalmente da área de exatas, então você tem sempre que estar mostrando capacidade entendeu?. Meu ibope, que lá tem essa coisa de ibope, sempre foi alto e sempre se achou uma desculpa para o meu ibope ser alto, é porque eu tinha um bom relacionamento com o dono ou porque eu usava saia e os alunos gostavam de ver minha perna, eu ouvi muito dessas coisas assim...então eu sou muito séria na sala dos professores, até porque quando eu entrei no cursinho eu fui muito expansiva e os homens...Eu achava assim.. num meio de professores que são pessoas educadas não existem generalizações e preconceitos e então eu poderia ser super assim .. eu era meio Ripoca sabe? Feliz da vida e tararara...aí um professor me interpretou mal e tomou uma atitude que eu não gostei, eu fui assediada por ele, eu reclamei com a escola e eu ouvi coisas do tipo a Maria é tão brincalhona como é que ela não tolerou esse tipo de brincadeira? Ah! Eu falei então tá....então agora eu vou ser diferente. E então como o meu universo é muito masculino porque eu estou na área de química e no cursinho só tem professor, basicamente homem que sobrevive nesse universo, então eu sou muito fechada com eles, então eles me acham muito séria, ninguém conta piada suja perto de mim, entendeu? Eu sou muito ética, né! Isso é assim ...é norma de vida minha, assim se eu tenho que estar fazendo alguma coisa, eu tenho que saber se vai prejudicar alguém, eu tenho que saber qual é o peso dessa palavra, eu sou incapaz de fazer uma piada racista, eu não tolero piada racista , né!., E no cursinho os homens são muito mulherengos, a grande maioria eu diria que $90 \%$ não são casados. Já foram casados, pela terceira, quarta vez e no momento estão sozinhos, então "pegam" menininhas de 18 anos e depois contam na sala dos professores que "comeu" uma menininha de 18 anos. E eu me indigno com isso, eu falo: quero ver você "comer" uma de sua idade cara, porque uma da tua idade não vai cair nessa "lábia safada sua", mas "pegar" uma menininha de 17 de 18 anos é muito fácil, né? Esse é o ambiente no qual eu vivo. No superior eu não tenho muito contato (com outros professores) porque eu dou aulas de sábado para licenciatura e a maioria é mulher, então a gente se dá super bem. A Nara que trabalha comigo aos sábados acha que eu sou super feliz, super bem humorada la..lara.lara. A Petra que é outra professora com quem eu estou trabalhando, acha que eu sou assim super alto astral né..mas acho que isso foi um caminho que eu descobri que é esse jeito bem humorado de passar o conteúdo que é o jeito que eu conseguia de ser eficiente, por isso que eu te falei que é como se baixa um santo, porque é como se quando eu vou dar aula eu me dispo das minhas preocupações interiores, dos questionamentos que me acompanham na vida inteira e eu ...faço não..agora vamos tranquilinho, vamos passar esse conteúdo, qual o melhor jeitinho de passar isso, eu sinto que eu to fazendo...embora as vezes é como se eu fosse uma atriz ..mas sabe...é que aquilo vai fluindo normalmente porque eu me sinto extremamente à vontade com os meus alunos, né, eu me sinto bem...Mas porque isso? Mas é uma incoerência porque na verdade eu não sou uma muito social, eu sou uma pessoa um pouco anti-social, [...] Na sala de aula eu adoro...eu não sei te explicar.. se uma aluna tem uma dúvida eu vou lá, se ela tem cabelo comprido, as meninas normalmente tem, então eu vou explicando e mexendo no cabelo dela assim,..parece que são todos minhas crianças... eu acho que essa é a diferença, entendeu? Então por isso que é tão gostoso...eu me sinto meio com eles, eu estou interagindo com eles e acho que é por isso acabo passando essa visão (de felicidade). E com a maioria dos professores eu não tenho por causa do ambiente que eu estou vivendo que é masculino, que é machista, que não é ético, que tem muita história de 'comi' fulana ..que isso me irrita profundamente, né, é muito baixaria né. Na faculdade onde esse ambiente é um pouco mais fora porque eu tenho pouco contato a não ser com a Nara que dá aulas de sábado comigo e que me acha super alto astral, né.. 
O professor que eu gostaria de ser. Ah..eu só gostaria de atingir mais..eu não acho que eu estou no caminho errado não, eu gosto do que eu tenho construído, entendeu? Só que eu acho que sempre tem um jeitinho melhor, entendeu? Então talvez essa causa ambiental, eu acho que ela faz com que a química passe a ter um interesse maior sabe? Então talvez eu eu..esteja estudando tanto para me aprofundar e também para estar produzindo e distribuindo esse conhecimento e que não está sendo gerado não só em relação ao conhecimento mas em relação ao mundo como um todo. $\underline{O}$ equilíbrio ecológico que aí envolve uma série de coisas e se eu conseguir transmitir o meu conhecimento, transmitir a química e essa química atingir esses caras de tal forma que eles se tornem mais éticos, mais cidadãos, mais responsáveis, mais generosos. É esse professor que eu gostaria de ser ..eu diria é aí mesmo que eu quero chegar. Eu não sou uma má professora, entendeu? Só que talvez eu precise adquirir novas técnicas para ser mais abrangente e produzir um conhecimento bom, generoso, equilibrado, entendeu? Não só misturar ácido com base que vai dar sal e água mas... porque misturar acido com base e o que eu vou fazer com esse sal e água? Que utilidade isso vai ter pro mundo? Pra vida dessas pessoas? Quanto mais eu colaborar para uma vida melhor ...mais eu vou me sentir uma boa professora, entendeu? 
ANEXO 8: entrevista Maria

\section{Todos os nomes de pessoas, locais e instituições foram trocados para preservar a identidade do} pesquisado.

É... Maria... Eu tenho 49 anos... E trabalho desde 1978... Eu não sei quanto tempo que faz isso já, quase 30 anos.( Suspiro). Eu sempre trabalhei com ensino médio, porem só nesse ( primeiro) ano que eu peguei sétima e oitava de resto a vida toda foi sempre ensino médio com ensino de química.

1.Você se considera uma professora? Por quê?

Rsrs... (Voz sorridente) Eu me considero uma professora! Eh... Professora no sentindo assim, olha, não sei se eu tô falando certo isso aí, mas eu penso assim. Eu me preocupo com o que eles aprendem... Com as dificuldades que eles apresentam... Com as atitudes, como é que...ãh... me preocupa pensar que é um aluno... Eu vou encontrar um dia e ele passou pela minha mão e não ficou melhor do que ele era antes. Isso me preocupa muito. Então eu acho que isso é ser professora. Não sei se era isso que vc queria saber, mas é isso que eu penso.

\section{Qualquer pessoa pode ser professor? Por quê?}

Não. Não, eu acho que não pode ser professor qualquer pessoa, assim como não pode ser medico qualquer pessoa , qual... qualquer pessoa, nem pode ser engenheiro... Num, cada um tem um dom maior, eu eu acredito. (Pausa) Tem que ter um idealismo, um alguma chama que não morre e que é um porquê na sua vida, eu acho que é uma busca, é uma coisa que dá sentido, é... Eu acho que cada um tem isso na sua... na sua profissão ou tem que ter .Eh isso que faz permanecer numa profissão, eu acho.

\section{Que atributos distinguem a profissão docente das demais?}

(Suspiro profundo). Primeira coisa que eu nunca tinha percebido mas alguém me falou é assim. $\underline{\mathrm{O}}$ professor ou professora vai ser sempre o professor ou professora, parece que perde o nome. Então, eu encontro na rua até hoje, (retomada de fôlego) encontrei a filha da Irma muitos anos que eu dei aula. Professora, professora, professora..... Eles me chamam de professora sempre. E então acho que isso tem alguma coisa diferente do que as outras profissões, porque trabalha intimamente com pessoas que no meu caso tão em formação, eu acho que forma muito caráter nesta época, muito de personalidade, então eu acho que é muito importante ter esta noção, não sei se eu to dando demais importância, mas é como eu sinto (retomada de fôlego). E... então é alguma coisa meio que privilegiada. Além de mexer com o conhecimento, que é o saber, a bagagem mesmo cognitiva desta pessoa tem o emocional, que é muito envolvido, porque o adolescente ele, ele é tudo ...Tudo é sentimento ele odeia ele ama com muito ardor, então eu tenho a impressão assim que é muito diferente do que qualquer outra profissão, por isso aí que eu penso.

4. Você consegue tecer uma linha lógica falando sobre os motivos que te levaram a ser professora?

Não. Rsrs... Eu não consigo. Porque quando eu era pequena eu gostava de brincar que eu era professora. Eu tinha até uma régua que eu achava que tinha que ser brava e eu brincava com as meninas, eu dava reguadas, toda a vez que não me atendia. A gente brincava muito de professora. Ai passou..., quando eu cresci aquilo lá passou por inteiro. Passou e eu fiquei me perguntando da minha profissão, eu tinha que trabalhar..... meu pai nunca foi um homem rico e tinha três filhas e eu sou a mais velha. Por mal dos pecados eu entrei numa faculdade paga. E... meus irmãos também. Minha irmã estudava também em colégio pago e eu tinha que trabalhar. E quando eu tava no meu penúltimo ano eu pensei, eu não posso mais continuar assim, não por pressão deles na verdade, mas era uma pressão muito interna minha. Fui fazer química porque eu era apaixonada pelos professores de química que eu tive, eu acho. Eu sempre tive muita facilidade. E aí eu fui procurar emprego. Mas o meu emprego que eu fui procurar, que eu trabalhei sempre, eu estudei sempre foi para ser bacharel! Eu fui em todas as firmas e laboratórios da Via Dutra praticamente. Eu fiz... Eu com uma amiga minha fizemos ficha onde deixaram, que na época tinha lugar que nem deixava a mulher fazer! E nós fizemos ficha, nós ãh tentamos fazer estágio, eu fiz de cimento, eu fiz de tinta. Embora eu tenha ido bem eu nunca fui chamada para trabalhar num lugar assim que era o meu sonho! E aí quando eu vinha vindo deste dia que eu tinha que achar emprego de qualquer jeito 
Numa das firmas lá na Vila Guilherme, uma amiga minha que trabalhava lá que a gente encontrou .Ela falou assim:

- Naquela escola (e mostrou o colégio onde dei aula durante 15 anos) tão precisando de professor de química a noite. Era tudo o que eu queria! Porque eu tinha que ter um emprego. Eu fui, eu pensei assim: eu dou um pouco de aula até me formar, e depois saio fora e continuo com a minha vida do que eu quero. Fui peguei o emprego. Comecei...E me apaixonei! Não conseguia nem dormir sem corrigir prova. Se eu desse prova de noite pra eles, eu tinha que chegar e corrigir, pra ver como eles tinham ido se tinham ido bem se tinham ido mal se tinham entendido o que não tinha. Eu...eu comecei a largar a faculdade por completo. Isso foi em 78. Em 80, eu me formei em 79, eu não tinha nem diploma,veio o exame do Estado e eu queria continuar, eu queria continuar pra ver um significado porque era muito legal trabalhar naquela época, foi muito bom. Inclusive minhas tias me ligaram todas, que elas eram todas professoras, acho que já vem um pouco de família né? Elas me ligavam e me diziam assim:

- Para! Sai daí! Sai daí porque você vai ver que isso é uma armadilha no começo é bom..... cê nunca vai subir na vida... cê nunca vai ganhar o que cê acha que ce merece, sai desta profissão! E eu não tinha coragem de sair. E o meu pai falou para mim faz o que você quiser. Aí foi quando eu fiquei quer dizer, eu não tive uma linha lógica, eu passei no exame muito bem e escolhi a mesma escola que eu estava e aí eu fiquei né? Eu não sei se me acomodei, mas eu fiquei. E ate 1996, 97 eu achei que foi muito bom depois eu acho que caiu muito, mas até então sempre foi muito bom.

5. Você conhece algum professor que não deveria ser professor? Conheço, conheço, conheço e conheci. Conheço ãh eu trabalhei em muitas escolas, em muitas regiões. Conheço professor que, ah por algum problema sei lá moral ...cantava os meninos, saia com os meninos, teve um problema grave num colégio que eu trabalhei, que eu acho que era só para se aproximar deles. Conheço muitos que a única coisa que eles conseguem fazer é transmitir um recado que isso todo mundo faz né? Não é uma aula. Que não conseguiu fazer outra coisa. Conheço muita gente que faz bico da nossa profissão. Isso eu acho uma coisa assim muito revoltante, mas eu conheço, então eu conheço.... as vezes eu acho muito fácil o acesso..

\section{O que seus pais acharam de ter um filho professor?}

É meu pai nunca foi contra nem a minha mãe. Nunca. Quer... Quem foi contra foi o restante da família. (carros passando). Que foram as irmãs do meu pai que eram todas professoras. Porque o meu pai sempre agiu assim, comigo e com os meus irmãos. Faz o que você quiser. Faz o que você gosta e que dê para você se sustentar. E... Nunca, nunca assim foram contra, nunca!

\section{Quais as lembranças mais marcantes do seu período de escola?}

Escola ....escola professora ou escola aluna? Escola aluna.

Escola aluna, lembrança marcante? Eu acho que a primeira coisa muito marcante que eu posso dizer foi ter um grupo que sempre continuou comigo que foi o grupo da $5^{\mathrm{a}}, 6^{\mathrm{a}}, 7^{\mathrm{a}}$ e $8^{\mathrm{a}} \cdot 1^{\mathrm{o}}, 2^{\mathrm{o}}$ e $3^{\mathrm{o}}$ que era o mesmo grupo de amigas que seguiu praticamente, que hoje encontro algumas, eu acho que isso foi muito marcante pra mim. (Suspiro) Muito marcante foi... uma dificuldade de geografia sempre, sempre desde novinha muito horrível, que eu fui super, eu fiz um mapa que não era para ter feito. $\mathrm{O}$ professor me ri...ridicularizou na sala inteira, isso eu nunca mais vou esquecer! (Tom jocoso) Ele deixou para o final e mostrou, falou:

- Olha uma aluna fez isso. Eu era a única aluna que faltava receber o mapa era eu. E ai então eu acho que isso foi uma coisa bem marcante.

Foi muito marcante um professor de biologia, que eu tive, sensacional! Um professor de uma amizade na época que não era comum. E ele tinha uma amizade assim, muito bravo ele era... mas ele orientava, orientava mais do que tudo.

Ãh...Professores. . Olha, do meu segundo ano do primário foi dona Diana que era uma mulher parecia uma mãe da gente. Meu professor de biologia, meu professor de química que eu odiei e depois amei pela... Pela exigência dele e depois pela preocupação que a gente soubesse mesmo, ai que a gente foi conhecendo mais e aí ...ia gostando cada vez mais dele. Muito marcante foi o meu professor Antonio de química que era uma pessoa que transmitia bondade e competência o tempo todinho dentro e fora da classe e aquilo lá era uma coisa que transpirava e para mim foi muito legal. É... A minha formatura de $8^{\mathrm{a}}$ serie que eu não liguei nem um pouco pra o meu pai e nem pra minha mãe e aí eles ficaram super chateados comigo. Eu só fui ver muito depois, porque eu não fiquei com eles nem um minuto. Daí detestei tanto aquilo, que nunca mais eu fiz formatura. Eu não quero mais... Se eu fico com um amigo 
fica chato. Se eu fico com eles era muito chato. Então eu não fiz formatura de mais nada, nem colégio, nem for... nem faculdade, nada. Acho que isso que é marcante assim na minha cabeça.

\section{Como foi o seu primeiro dia de aula como professora?}

Então... Eu passei o dia fora praticamente, né? Foi no dia sete de março de 1978. Hãh Eu passei,uhn, nós saímos da faculdade, né que eu tinha carro e nós fomos passear tudo que a gente podia pra procurar emprego em laboratório. Preocupadíssima que eu via que as coisas em casa estavam...preocupantes. A gente percebia pelo meu pai e pela minha mãe. Aí na volta, que eu acho que já falei pra você né? Encontrei com minha amiga que falou do colégio, e eu fui lá. E a diretora... fui lá e falei eu quero... sou professora de química, eu to me formando...né? Me apresentei toda, ela disse assim pra mim: Pode ficar, então as aulas são suas. Aí eu falei: Ah, então ta bom, e me aprontei pra ir embora, peguei minha bolsa. E falei, quando que é o horário. Ela fez assim, pra mim:

Já! São sete horas, sete e quinze cê tem que tar na sala.

Nunca mais eu vou esquecer disso! Eu olhei pra ela e fiz assim:

Eu não posso! Eu não preparei aula, eu nunca entrei numa sala. Eu num posso!

Ela arrancou umas folhas assim do caderno dela, me deu e fez assim:

Hoje você vai passar, e vai pegar o nome de cada um. Perguntar da onde eles vieram. O que eles querem fazer da vida deles. Hoje você vai conversar. E a aula vai passar. Hoje,.. você entra já, ou as aulas não são suas mais, você que sabe.

Eu peguei a folhinha, e tudo que eu podia... eu tremia, é a primeira sala de aula. Até eu lembro da menininha que tava na frente de óculos, bem miudinha. Eu não sabia nem o que dizer, né? Aquela sala imensa, a noite, e eles foram sensacionais, né? Aí eu fui, perguntei o nome de cada um, e num sei se era naquela época ou se eu que tinha muita ilusão, eles tinham muito sonho, de se formar, fazer uma faculdade, viver melhor, cada um queria ser uma coisa... Ah... Foi muito legal!Aí eu lembro...depois que foi o primeiro dia. Aí eu fui! Passou cinco aulas... E aí foi me deixando...feliz! Eu fui ficado feliz, feliz, feliz... E aí eu comecei, então esse primeiro dia não dá pra esquecer mesmo. Rsrsrs

9. Relate bons e maus momentos ocorridos em sua sala de aula. Como foi sua atuação nessas situações?

Olha! Bons momentos eu acho é quando eu consigo, e toda vez que eu consigo alcançar os meus alunos. Deles assim, deles estarem... Porque química é uma matéria antipática muitas vezes. E aí quando eu consigo mostrar pra eles, ou ir desenvolvendo algum assunto com eles e que eles vão se interessando, ou porque a gente contextualiza, ou porque eles vão perguntando e vão aprendendo, esses momentos foram muito bons. (Retomada de fôlego). Muito bons momentos foi ter alunos que vieram falar pra mim que vão fazer Química, Engenharia Química, Bioquímica... Que... Graças a Deus isso acontece até hoje. Quer dizer, você de certa forma acaba influenciando positivamente esses meninos.

Maus momentos, eu tenho... Ahn visto mais vezes agora ultimamente, é o desinteresse, a falta de perspectiva de estudar. Uma falta... acho que da própria escola de (impor) limites sobre esses meninos que seria muito interessante. Então você não pode marcar muito se não fez uma tarefa, você não pode ficar muito brava. Eu acho que o que eu tenho medo.. que as vezes eu penso, que tenho que me aposentar logo e, isso aí me dá um pouco de medo... É quando eu vejo que ... o que eu.. Eu não quero judiar, eu quero formar. Mas pra formar cê tem que ter alguns limites. Tem que ter alguma ... ah... algumas normas sociais na sala. E eu não tenho sentido isso nas escolas particulares que eu tenho ido mais vezes, certo? Então... Por um lado isso é uma coisa difícil isso. Eu espero que seja só esse ano talvez que. ..Porque em umas séries foi melhor, outras foi um pouco pior. E em algumas dá vontade de se ir embora porque eles não tem nenhum limite. Não pegam o caderno é culpa minha, eu que não influencio, ah... Aquela coisa... Tudo , tudo nas costas do professor. E a escola se redime. Então a orientação, coordenação, ninguém vai sujar seu nome e ninguém, e ninguém vai dar respaldo, porque é o cargo também da pessoa. É horrível sentir que você tem um cargo só a zelar, entendeu? Assim, numa escola eu acho que num..., num poderia acontecer isso. Isso eu sinto falta do Estado. Agora..eu também larguei o Estado, porque o Estado também não tava sério, tava.... Tanto faz. Eu dar aula ou não dar, eles iam passar do mesmo jeito. Eles não sabiam nem mais ler. Eu levava texto e ninguém conseguia ler. Isso foi horrível! Foi uma lem... uma experiência muito má. Eu peguei texto sobre agrotóxicos, que usava na particular, e levei pra gente discutir a noite, de química orgânica. Os meninos não sabiam o que significavam as palavras, eles não conseguiam fazer uma idéia, ao ler um 
parágrafo. E aí foi o ano que eu pedi minha exoneração, que eu pensei.” Ai, eu tô muito cansada disso tudo!”

E acabei indo procurar. Vou procurar todo ano, eu acho que acabo indo procurar alguma escola que me de um pouco mais de satisfação, em algum ponto! Então eu acho que... Bons momentos são esses, bons momentos são quando o pessoal pede mais aula né? Esse ano aconteceu muito, falar "Ah! Muito pouca aula. Eu quero mais! É muito bom! Muito gostoso! Com essa introdução que eu to dando a Física e Química E maus momentos, que maus... (suspiro) Não só pra mim! Mas porque eu acho que pra eles, tão formando pessoas sem garra nenhuma. Em muitos lugares. Porque ta muito paternalismo, e... Isso parece que é muito ruim pro professor, mas eu acho que é muito ruim pra eles. Esses são os piores momentos, eu acho.

9. O que a torna professora?

Acho que ainda é meu idealismo! Eu acho que o que mais me irrita, muitas vezes é a questão minha de idealismo, me orgulho de... Acho que é uma coisa bem besta que todo mundo deve achar. Vou te falar, é isso que eu penso. Quando eu encontro um menino ou uma menina que fala assim : "Cê foi minha professora, que tempo, lembrar e saber que eu dei uma contribuidinha... Esse orgulho, me faz bem! Isso aí me faz bem pro meu ego.

\section{O que te mantém professora}

Primeiro que é o que eu sei fazer. Eu acho que é o que eu consigo ainda... Trabalhar. Eu, eu eu acredito isso. Eu... O que você quiser... Vamos supor, em que sala você quiser. O que você quiser que eu dê aula, eu me sinto bem, porque eu consigo fazer, eu consigo.. eu sinto né? Eu não sei se eu to certa, mas também é minha visão. (Suspiro). Então, isso me mantém! Primeiro lugar! Eu acho que hoje eu num, num buscaria outra coisa. Quando' eu me aposentar, vou vender jóia. Mas aí é uma coisa pra... até pra poder só... brincar um pouco com a vida vai, vamos dizer. Mas o que me mantém professora, que faz eu estudar... Pq eu ainda acredito... que só pela educação que nós vamos chegar a alguma coisa... melhor, num futuro. Pro próprio mundo. E ou é... muito , com muita vaidade eu acho que eu to contribuindo quanto a isso. Eu acho que é isso aí...rsrsrsr (voz rindo)

\section{O professor que eu sou! Que professor você é?}

Eu? Eu sou uma professora... Que a primeira vista eu sou extremamente séria, então as primeiras aulas são muito difíceis nas classes, porque eu sou muito séria com eles... Eu... acho que para não perder a autoridade, não sei. Eu sou muito séria, depois eu sou uma pessoa que vou tentando me aproximar muito, e pelas próprias dificuldades que vão aparecendo eu vou me tornado uma pessoa muito... amiga. Isto eu espero sempre acontecer, porque senão acontece também, eu nunca forço. Tem sala que isso nunca acontece,mas eu gosto quando isso acontece. Suspiro. E eu sempre tento ser uma pessoa que tenta usar o máximo de competência e honestidade com eles. Se por acaso não dá tempo de eu ver alguma coisa, eu acho que não foi muito legal... aquilo me incomoda extremamente. Então eu acho que eu ainda sou uma pessoa que mantém uma seriedade... ah... eu me responsabilizo pela sala, e por mais que eu pense que eles vão um dia ver em outro contexto, eu sempre penso: Pode ser a última vez na vida deles que eles tenham química. Então, é assim que eu vejo. Eu sou uma pessoa que acho que é isso que me... que me caracteriza melhor, eu acho, que é o idealismo. Sempre eu acredito que vai mudar, que vai melhorar. E que vai ter que buscar. O dia que eu perder isso acho que eu não posso mais entrar na sala de aula.

O professor que dizem que você é. O professor que dizem que eu sou. Que dizem que você é. É, eu não sei o que dizem de mim.(os alunos) Vou falar pra você...infelizmente... porque as escolas fazem as avaliações e dificilmente passam pra gente. Eu to sabendo que esse ano fizeram lá no ensino médio, mas até hoje não chegou nada pra mim. E sei que sou uma pessoa no começo difícil de se aproximar, pela fala dos meninos e das meninas que tem uma idéia bem afastada de mim no começo. Porque eles falaram... Parece que você era tão distante. É estranho, então eu sei que no começo eu sou uma pessoa que num dou muita proximidade, eu acho. Num sei o que dizer mais de mim. Acho que só perguntando pra um aluno, aí fica um pouco difícil mesmo.

E os outros professores?

$\mathrm{Eu}$ acho que eles gostam de mim (os outros professores). Parece.. porque eu tenho um relacionamento social muito bom. Eu crio amigos nos lugares que eu vou. Normalmente agente cria amigos e acaba se visitando e trabalhando junto. Na escola que eu to que é nova, né? Algumas pessoas vieram (me procurar) pra gente trabalhar assuntos me oferecendo aquela coisa assim...trabalhar interdisciplinarmente. Que eu achei que foi muito legal. Eu não era nada conhecida. Então eu sinto que 
pelo menos parece que não tem nenhuma porta assim me fechando. Que eu consigo me relacionar. Agora que professora eu sou de verdade? Eu também as vezes queria saber melhor como as pessoas me vêem.

O professor que eu gostaria de ser-Eu gostaria de ser primeiro, com a experiência que eu tenho hoje, mais nova. Eu acho que com a idade você vai ficando mais.. ah... ranzinza, mais chata.. eu sinto que não dá certo. Na oitava tem hora que eu penso: $\mathrm{Ai}$, não é verdade que eu to aqui dentro. $\mathrm{E}$ eu acho que uns cinco seis anos atrás eu era melhor. Então eu sinto que eu não tenho mais... eu eu eu tenho medo de não apostar numa sala novinha como essa, entendeu? Que pra mim foi um super desafio. Então eu gostaria de ter mais vitalidade, subir e descer as escadas e não sentir dor nas pernas. Eu queria ter mais vitalidade. Eu sinto infelizmente que eu to tendo mais experiência, mas a escola não pede mais experiência pra mim. Ela pede mais vitalidade. Quer que eu vá pra um Hopi Hari. Mas eu não tenho essa disponibilidade, porque eu não gosto disso. Eu faço estudo do meio! Estudo do meio, não é passeio! É para ir visitar Angra, pra trabalhar, ver um trabalho, um projeto. Então eu sinto que to ficando inflexível em algumas questões da escola, que pra mim não tem razão de ser e eu acho certo até.... Mas isso é ruim porque eu acabo fechando alguma coisa. Ainda Graças a Deus não fechou mas, (toctoc toc na madeira) eu to esperando. Rsrs 
ANEXO 9: entrevista Deise

Todos os nomes de pessoas, locais e instituições foram trocados para preservar a identidade do pesquisado.

\section{Você se considera um professor?}

Me considero, é a profissão que eu escolhi que eu trabalho já há muitos anos porque eu quero não foi por falta de opção de outra coisa .. eu acho que estou na área da educação sou uma educadora porque eu me preocupo com o que os alunos aprendem como eles aprendem como fazer pra eles melhorarem a aprendizagem e também a relação com o mundo que o cerca .

2. Qualquer pessoa pode ser professor?

Eu acho que não ..tem gente que não tem...não só o conhecimento é importante para ser professor, ele é super importante, mas acho que tem que ter não sei se é dom a palavra mas tem o..é..um pouco sobre as metodologias, ai meu deus e agora..., sobre a prática de ensinar e tem que saber ensinar, porque nem todo mundo tem essa....habilidade.

3.Que atributos distinguem a profissão docente das demais?

Muita paciência, pesquisa o tempo todo, ta sempre procurando coisas novas, si.., pra poder trabalhar em sala de aula, pra poder conhecer ler um pouco sobre as teorias de aprendizagem, conhecer um pouco sobre isso , pra não ficar o que aprendeu a 20 anos atrás pra não achar que aquilo é sempre correto .é...i saber lidar com o adolescente é saber lidar com o outro .

Dedicação ao trabalho os professores tem que ter, os professores tem que ter conhecimento, lidar com o outro quase todas as profissões precisam ... saber interagir com o outro pensando na aprendizagem eu acho que não precisa ser só professor, mas eu acho que o professor é quem mais precisa disso. E ouvir o outro pra saber como ele está conseguindo absorver aquilo que você está tocando com ele, eu acho que só o professor...é intrínseco do professor

\section{Quais os motivos que te levaram a ser professor?}

$\mathrm{Eu}$, desde pequena gostava de... compartilhar aquilo que eu aprendia se os amigos não estavam entendendo eu ia lá , era coisa minha de querer ajudar meio que ajudar o outro no conhecimento, então eu vivi dando aula gratuitamente (risos) para muitas amigas muitas vizinhas , é uma coisa que sempre me preocupou, sempre procurei...lugares para estagiar onde eu tinha que ensinar alguma coisa, então...acho que a vontade de ajudar, de fazer o outro entender e ampliar o conhecimento..como eu sempre gostei disso porque eu sempre fui privada de algumas coisas aprendi a ler com jornal de açougue, não tinha livrinho não tinha nada então eu queria que os outros algum dia conseguissem chegar aonde eu cheguei

\section{Você conhece algum professor que não devia ser professor?}

Vários,ah.... por motivo de não ter conhecimento da área suficiente, que eu acho que, que eu poderia, ..sou química e poderia dar aulas de física , eu já dei aulas de física no começo de minha carreira, mas eu acho que não seria bom eu dar aulas de física porque precisa conhecer mais a fundo a disciplina , não é só ir lá e jogar as formulinhas, que mais, não saber lidar com o outro e não saber transmitir conhecimento, ele acha que ele ta certo que é aquilo lá e pronto ele não sabe interagir .

\section{Que seus pais acharam de ter um filho professor?}

No inicio acharam bonitinho uma filha ser professora, depois como eu fiz o curso de química que dava mais opções, mas depois viram que era a carreira que eu queria. Só acham que eu trabalho muito para ganhar pouco .

\section{Quais os eventos mais marcantes do período de escola?}

Mais marcantes?.. Um muito marcante uma feira de ciências no Anhembi ,quando eu estava no ensino fundamental na 6.a ou 7.a serie foi o fato mais marcante pra mim foi quando eu falei eu quero fazer ciência eu quero trabalhar pelo menos na área de ciência, porque eu via que a coisa do conhecimento di..de conhecer mais coisas eu vi o mundo maior do que eu estava acostumada na escola , isso foi marcante o professor pegando seus alunos enfiando num carro e levando no Anhembi, nunca fui em feira nenhuma e o livro que que eu ganhei na quarta serie Reinações de Narizinho a professora me deu por eu ser uma boa aluna..isso sim foi muito importante para mim ..eu nunca tinha ganhado um livro de leitura, então foi muito importante.

7. Como foi o seu primeiro dia de aula como professora? 
Tremi bastante a mão suou ...mas rapidamente eu consegui... interagir com os alunos era uma turma pesada de escola pública noturno, muitos viciados fedendo maconha e eu muito novinha tiravam sarro dizendo.. escuta senta pra ter aula a professora já vai chegar ..aí eu consegui meio que entrar na deles falando um pouco de música, de rock, coisa que eu nem curto mas eu falei a gente ta aqui pra estudar eu falei o seguinte agente vai aprender eu não vou enrolar ... e eu ganhei a turma com isso. Foi super legal foi uma experiência muito boa pra mim.

\section{Relate bons e maus momentos ocorridos em sua sala de aula ?}

Bons momentos é quando você consegue mostrar como é importante o conhecimento e falar ó vamos aprender, esses são os bons momentos, de eu conseguir fazer uma aula com a turma e manter por exemplo ficar até mais tarde numa escola que tudo mundo ia embora as 10 da noite quando a diretora ia embora e eu falava não a gente vai ficar até a hora de acabar e aí eles falavam vamos então professora e aí ficavam pra aprender não pra brincar e isso foi muito legal

Algumas escolas em que eu trabalhava de uma maneira cursos mais temáticos, dava química dos alimentos eram momentos muito bons em que a turma se envolvia, agora o problema da indisciplina é um problema meu que me atrapalha e com as novas gerações parece que está sendo pior, e quando eu não consigo fazer com que a classe fique.... envolvida com o conhecimento com aquilo que eu to querendo trabalhar com eles, ou com o que é desejo deles eu vejo que não tão muito aí são com coisas que vem deles que me pediram eu fico muito frustrada, eu não consegui resolver isso ainda o que fazer quando os alunos não estão nem aí.

\section{O que te torna professora?}

Eu não conseguiria fazer outra coisa é...acho que o que me dá prazer é ser professor , se fosse por outro motivo, por exemplo financeiro, eu acho que já teria arrumado outras opções é que eu gosto de poder passar pra alguém algo maior que essa pessoa não tem , é...eu acho que professor não é só na sala de aula, eu tenho parente e sempre eu to lá explicando alguma coisa, é pessoal eu acho.

\section{O que te mantém professora?}

Agora é minha profissão, preciso dela para sobreviver e ainda eu acho essa coisa de ver o brilho nos olhos de alguns..alguns já não são todos mais, que eu via antes que eu acho que eu era mais empolgada , né.. é essa coisa de dizer que legal então era isso? Essas coisas ainda me fazem...um pouquinho que acontece num dia ou outro, isso me ajuda a me manter como professora

O professor que eu sou- Preocupada... com o conhecimento menos pesquisadora do que antes não na parte pedagógica mas da parte do conteúdo ..da ciência, ando lendo menos eu acho que eu devia ler mais porque eu ai ter argumentos melhores para discutir com os alunos, é e me preocupando com a melhor maneira de fazer os alunos entenderem o mundo que os cerca.

O professor que dizem que eu sou-Engraçada ...as vezes chata e ..não tão rígida como deveria ser . O professor que eu gostaria de ser -Mais rígida, mas não rígida só pelo ...mas ter um respeito maior pelo que eu sou, não por algumas coisas que eu pudesse fazer que provocar, ter um pouco mais de aceitação só pela minha pessoa ..que fosse suficiente mas ai eu tento contornar isso e...lendo estudando pra ver se eu consigo melhorar esse lado, eu gostaria de ser um pouco mais saber mais principalmente estudar mais pra conseguir trabalhar com os alunos de uma forma mais ativa, mais atividades mais projetos, mas ..o tempo vai passando e agente vai deixando coisa . A gente sempre fica imaginando no começo do ano vou fazer tal coisa projeto tal ..projeto tal ..e nem sempre acontece o que a gente quer. 
ANEXO 10: entrevista João

\section{Todos os nomes de pessoas, locais e instituições foram trocados para preservar a identidade do pesquisado.}

1.Você se considera um professor? Por quê?

- Nossa que pergunta subjetiva a sua.

- Considerar um professor é um negócio meio complicado porque assim: Se a gente fosse pensar pelos moldes da educação que a gente vê hoje eu não me considero um professor. Eu acho que eu sou... um mediador entre o conhecimento e o aluno. Eu não sei !. Acho que eu..., é assim..., é difícil você falar que você ensina..., né ? Eu acho que você apresenta; dependendo do lugar onde você tá, você apresenta para o aluno o conhecimento. Então...é! você ensinar é uma coisa completamente subjetiva. É uma coisa psicológica do aluno. O aluno... Você ensinar é uma coisa, o aluno aprender...Eu posso falar que eu to ensinando ... Olha ,eu to ensinando ! Eu dou aula do conteúdo . Eh, eu tento fazer com que os alunos.... desenvolvam as competências que eles tem que desenvolver. As habilidades que eles tem que desenvolver... Pra eles serem considerados...depois ter um conhecimento básico para ser considerado letrado cientificamente (que é o negócio da minha dissertação) mas que eu acredito nisto. Eu geralmente tô fazendo isto porque eu acredito que o aluno ele pode ser, ele pode ser letrado cientificamente. Ele pode ter conhecimentos básicos para entender coisas básicas,fenômenos básicos da vida dele,que envolvem ele. Mas eu posso falar que eu estou ensinando... mas o problema entre ensinar e aprender são coisas completamente diferentes. Tem um abismo no meio. Né ? Então não dá. Eh! Eu acho que a visão de ser professor antigamente era uma visão de que: você vai, ensina o aluno e o aluno aprende. Se for pensar neste fato eu não sei se sou professor. Eu acho que eu não sou professor. Eu acho que eu apresento conhecimento para o aluno e eu tento criar condições para que o aluno, ele consiga apreender este conhecimento de alguma forma e utilizar este conhecimento para a vida dele. Agora, se isto é ser professor eu não sei. É isto o que eu faço.

2.Qualquer pessoa pode ser professor? Por quê?

Não. Não é qualquer pessoa que pode ser professor. Eu não acredito que qualquer pessoa que pode ser professor. Eh, eu acho que qualquer pessoa se tiver bom... assim ... Se gostar daquilo que está fazendo, se gostar do aluno, gostar de tratar com pessoas, tiver uma paciência enorme, porque a gente precisa ter uma paciência de Jó para tratar com estes alunos. O pior de tratar, não é nem tratar com os alunos. O pior é tratar com os próprios colegas, com os próprios professores. Isto é um negócio seríssimo! Então, eu acho que a pessoa pode aprender a fazer o que eu faço. Se ela tiver, eh, ... paciência. Se ela tiver perseverança. Se ela estudar bastante, se ela ler bastante. Se ela não for uma pessoa fechada. Se ela tiver uma mente mais aberta para entender algumas coisas que, ... com o que,... o cognitivo do aluno funciona, que é complicadíssimo de entender. Acho que ninguém entende, nem por completo nem por incompleto, como é que o cognitivo do aluno funciona. A gente tem modelos e a gente utiliza estes modelos de alguma forma e , as vezes dá certo e as vezes não dá. Eu acho...que nem todo mundo pode ser professor. Depende muito da situação de espírito da pessoa. Eh do que a pessoa gosta de fazer, se ela gosta de trabalhar com pessoas, se ela gosta de trabalhar com adolescentes, com jovens, com adultos... Sei lá ! Eh... Eh....A pessoa precisa gostar de trabalhar com pessoas e precisa gostar de estar inovando toda a hora. Ser uma pessoa criativa. E é isto que eu prezo bastante nos professores, nos colegas. Eu acho que eu tenho,isto daí é uma coisa minha, que acho que é até um preconceito, porque eh... eu tenho colegas que são criativissimos. Assim, de um alfinete o cara ensina ótica por alfinete, pelo brilho do alfinete o cara ensina ótica. Eu acho aquilo uma coisa maravilhosa, pois o cara usa aquilo como um espelho e o negócio é..., fica lindo. Mas tem gente que não tem criatividade nenhuma. E eu acabo escolhendo os colegas professores que vão do meu lado, que são aqueles colegas que tem criatividade, aqueles colegas que tem idéias legais. Que pensam em metodologias legais. $\mathrm{O}$ povo que tem uma boa vontade enorme de pensar em metodologia nova. Entendeu? E aquele pessoal que fica fazendo sempre a mesma coisa. Sempre aquela coisa velha, ensinando coisas como da década de 60, como da década de 50 se ensinava... eu acabo até afastando de mim. Então é um negócio meio de preconceito mesmo. Eu acho que tem pessoas que não tem dom para ser professor (se é que isto é um dom). Eu acho que elas não tem criatividade para ser professor. Então eu acho que não é qualquer pessoa que pode ser professor não.

Você acha que tem efeitos diferentes nos alunos o cara ser criativo, ou não ser? 
Tem. Tem efeito diferente nos alunos por conta de uma coisa só: Da motivação. Acho que você ser criativo, você incita a curiosidade dos alunos muito mais fácil. Né? Você levando uma coisa diferente, você falando de um modo diferente, você falando coisas diferentes, você colocando para eles...mesmo que seja para eles lerem, ou, para eles olharem algumas coisas. Por exemplo, o modo de apresentar a ciência, seja de uma forma tradicionalíssima: giz, lousa e saliva...Seja de uma forma um pouco menos tradicional, mas ainda tradicional, que é você colocar no... colocar na transparência, e projetar na lousa, e tal. Botar num datashow, sei lá, e colocar lá. De qualquer forma você está mudando o material que você está escrevendo, mas você está escrevendo. É giz, lousa e saliva . Não mudou as coisas né ? Tem uma coisinha mais, ou uma coisinha a menos, que é uma animação, uma coisa diferente e tal, mas é o modo de você apresentar. Então é assim. Mas, o simples fato de você não estar escrevendo com o giz na lousa faz com que o aluno veja em você um professor diferente, porque todos os professores que eles viram até agora fizeram isto. Entendeu? São poucos os professores que utilizam meio multimídia, que utilizam outras coisas assim. Principalmente quando você vai e faz uma experiência com eles. Você demonstra uma experiência para eles.

Que atributos distingue a profissão docente das demais profissões?

São estes que falei para você. A criatividade, o conhecimento que a pessoa tem. Que pode não ser um conhecimento tão grande, Também não vai ser um conhecimento muito pequeno. Entendeu? Acho que o conhecimento daquilo que ele vai ensinar, é um conhecimento que o professor tem que ter mesmo, não tem jeito. O cara fala: $\mathrm{Ah}$ ! O professor é muito conteudista. É conteudista mas aprendeu aquilo ... assim, desta forma. Né?. Com relação à pergunta anterior ainda acho que tem muitos professores que ensinam desta forma porque aprenderam desta forma. Né, e assim fica um negócio meio complicado, mas eu acho que o que distingue um profissional da área de educação de um profissional de uma outra área acho que é a paciência que ele tem de ter, acho que é a criatividade que ele tem de ter, acho que o conhecimento que ele tem de ter, não só da matéria dela mas, com relação ao que o aluno aprende, o que o aluno não aprende. O que é importante para o aluno aprender. Eu acho que ser professor é uma coisa que te dá a capacitação para você ser uma pessoa mais organizada com relação a algumas coisas. Eu não posso dizer muito isto porque sou desorganizado para dedéu ...Tenho uma desorganização enorme. Mas isto aí é uma coisa de criação. A gente é criado desordenadamente. Então eu acho que, mas acho que, pelo fato de eu ser professor e ter aquelas coisas ali, eu criei uma ordenação muito maior na minha vida hoje, uma organização muito maior na minha vida hoje do que quando eu era, sei lá, quando eu trabalhava na feira, por exemplo, ou de quando eu era outra coisa.

Você consegue tecer uma linha lógica falando sobre os motivos que te levaram a ser professor?

Hehe!. Eu não sei se consigo tecer uma linha lógica porque a minha vida não foi lógica. Hehe ! Eu fui tropicando no meio do caminho. ...Eu acho assim é...(suspiro)...Eu nunca pensei em ser professor. Nunca. Eu queria ser médico quando era moleque. Eu era louco para ser médico, louco para ser médico. E, só que depois eu vi aquela coisa e, eu tive um problema muito sério porque eu sempre fui muito pobre né? Fui criado pelos meus tios, criado pela minha avó. Né? E o meu tio, meu tio é militar. Então, eu passei um tempo da minha vida com ele. E o fato de ele de ganhar pouco e aquela coisa toda. E amar o Maluf de carteirinha, pra variar. Amar o Maluf de carteirinha, então ele achava que tudo que eu fosse fazer, ele chegava para mim e falava. Você é um moleque inteligente. Vai fazer alguma coisa que dá dinheiro. Né? Vai fazer engenharia. Eu olhei para a cara dele e falei: Onde você acha que engenharia dá dinheiro? Não sei, vai trabalhar com computação. Você gosta de computador. Como você sabe que gosto de computador se não tem computador em casa?

Essas coisas foram martelando um pouco na minha cabeça e eu sempre fiquei pensando junto com amigos e tal, e falando algumas coisas e falando: Pôxa vida! Vou fazer alguma coisa que eu goste. Eu fiz dois cursos técnicos: um curso de administração de empresas e um curso de contabilidade. Dois colegiais. Três anos os dois cursos, eu fiz seis anos de colegial. Da segunda vez que fui fazer o colegial, professores olhavam para minha cara assim, gente que já deu aula pra mim. Puta, mas o que você está fazendo aqui de novo? Vai para a faculdade fazer alguma coisa que preste. Ah! não sei o quê. Eu falei, não tenho dinheiro para ir para a faculdade. Ah! Presta a USP, presta não sei o quê. Eu falei: mas eu não tenho cabeça para entrar na USP cara! Olha só como é este negocio. O cara vai fazer o vestibular. O vestibular é concorridíssimo. As questões ...Eu não tive nada aqui. Não tive física, não tive biologia, não tive matemática direito, quer dizer, a minha matemática foi toda financeira desde $o$ primeiro ano até o terceiro. Eu não tive história direito. A história que eu tive história da psicologia, história de não sei quê , história de não sei quê ...eu nunca história, feudalismo, estas coisas normais eu 
nunca tive. Geografia eu nunca tive direito! Então eu nunca tive um ensino legal mesmo, legal mesmo no ensino eu nunca tive. Então como é que eu vou conseguir entrar numa universidade? Até que um cara que hoje é muito amigo meu e é diretor de uma faculdade. Ele, que foi meu professor de história. Ele chegou para mim e falou: João, vamos montar um grupo de estudos para a gente estudar para ver se a gente ... sei lá... consegue fazer um vestibular numa universidade pública e tal ? Na época eu fazia parte do grêmio da escola e a gente tava montando o a biblioteca. A gente montou a biblioteca, tudo e a gente acabou usando o espaço da biblioteca para fazer estes encontros. E montamos este grupo de estudos que ficou aí quatro anos. O primeiro deu certo porque teve uma menina que foi para a Unesp, teve um moleque que foi para a Fatec, dois entraram na USP.

E este cara chegou para mim e falou, meu, vai, presta e vê não sei o quê. Eu falei , mas cara não tenho dinheiro, não to trabalhando, to desempregado, vou fazer como ? O cara foi e pagou a minha inscrição. Pagou o manual de duas universidades. Pagou o da PUC e o da USP para eu fazer. Aí eu falei: agora que você pagou eu vou ter que fazer. Não era para você fazer isto. Aí o cara falou : Não mas agora eu já fiz. Vai lá e faz. Então eu vim e fiz. Quando eu percebi que num era bicho de sete cabeças entrar na Universidade de São Paulo. Aí eu coloquei na minha cabeça que eu ia entrar. Eu falei: eu vou entrar. Mas aí era um problema. Você vai prestar o que ? Naquela época não tinha treineiro para prestar. $\mathrm{Na}$ época tinha ... você escolhia uma das coisas... isto foi em 97 e 98 . Aí eu escolhi para química. Então este professor chegou e falou: cara porque você vai escolher para química ? Você vai fazer química e tem bacharelado ou licenciatura. Você pode trabalhar em empresas , industrias e tal ou pode dar aula. Aí eu falava: Puts, dar aula ? Eu já tinha experimentado algumas vezes no primeiro ano, no segundo ano com este negócio do grupo de estudo. A gente sempre acaba adquirindo um conhecimento maior de algumas coisas do que os próprios colegas da classe. Então eu ajudava muita gente dentro da sala. E teve uma certa vez que um professor de química lá, ia ter uma prova tal, não se o quê. Eu achei que o que o professor tinha passado na lousa uma coisa, nossa, uma coisa ridícula. E o povo com uma dificuldade doida. Aí eu falei pro pessoal: Se vocês falarem com o professor da aula anterior que era o professor de geografia. Eu explico para vocês como é que faz. O pessoal falou com ele e ele falou tudo bem, mas o quem que é vai vir um professor aqui ? Eles falaram não o João vai explicar um negócio para a gente. Aí ele falou: isto eu quero ver. E o desgraçado do professor foi quem fez mais perguntas (risos). Aquele desgraçado de professor fazia tanta pergunta, mas tanta pergunta que teve um aluno da sala que virou para ele e falou: Pô professor, fica quieto. A gente é que quer aprender o negócio, não é você que quer aprender o negócio. Ele falou já que eu estou aqui eu quero aprender. E aí este professor chegou para mim e falou, puxa legal o jeito que você explicou. Os meninos entenderam. Aí eu gostei da coisa. Entendeu ? Eu acho que o que me levou a fazer um curso para ser professor...

Então fiquei entre física, química e biologia. Tanto que quando eu prestei (em 97) de tanto os caras ficarem martelando na minha cabeça para eu entrar numa universidade pública, eu entrei em cinco. Eu entrei aqui , na Unicamp, na Unesp ,na Fatec e na Federal de São Carlos, na Federal de Santa Catarina. Nas cinco. E, aqui eu entrei para Física, na Unicamp para Química, na Unesp eu entrei para Biologia, cada uma em um curso diferente. Na Fatec eu entrei em Edificações e lá na Federal de São Carlos para física também. Tudo na área de ciências. Aí eu falei pros caras: vou fazer na USP mesmo porque é perto de casa, e outra...Então é assim...na pior das hipóteses eu vou ser professor. Olha a idéia ! Na pior das hipóteses eu vou ser professor. Olha a idéia que a gente tem de ser professor. Agüenta aqueles alunos falando um monte de baboseiras na sua cara. Mal criação de aluno. Tem que ficar gritando toda hora. É esta a idéia que a gente tem depois que sai do ensino médio, pois os professores fazem isto com a gente. Ganha mal. .... (fala das greves). Aí eu falei professor ganha mal para caramba, mas, olha ele pode ganhar mal, mas pelo menos ele está trabalhando. Acho que não dá para morrer de fome não. Então acho que vou ser professor porque acho que professor é uma coisa legal. Eu tracei esta meta porque, na verdade quem traçou este caminho para mim não fui eu. Quem traçou este caminho para mim foram professores meus. $E$ eu acabei gostando do caminho. Eu olhei assim e falei: Puxa é legal, vou fazer um negócio deste mesmo. Gostei da idéia.

Você conhece algum professor que não deveria ser professor?

Vários. Conheço vários e por dois motivos: Primeiro, um professor reclama, mas não reclama tanto. Algum coisa de bom tem que ter. Tem gente que reclama muito achando que nada está bom. E estes mesmos professores não gostam da escola....(Falou da boa prática do laboratório que ele utiliza) 
[...] Falei pra professoras precisamos esclarecer algumas coisas para a gente fazer experimentos simples com os alunos na sala. Eles fazem uma molhadeira, elas disseram. Eu disse que eles podem fazer aquelas experiências de Ciências que está no site da Faculdade de Educação. Eu passei aquelas filmagens para umas quatro professores da primeira até da terceira série. Os professores olharam aquilo e ficaram maravilhados. Disseram-Puxa vida que legal! Eu passei pra elas e elas disseram assim. -Mas isso aí é uma coisa que não dá para fazer dentro da sala de aula. -Mas como é que não dá para fazer dentro da sala de aula? Se eles fizeram dentro da sala de aula da periferia do Rio Pequeno, ali do Butantã. Puxa vida! Claro que dá, lógico que dá! -Mas não tem o material e tal. -A gente produz o material, é simples pra caramba. E outra coisa, vocês querem o material? O material que ela usou? Eu fui lá na Faculdade, catei o material, coloquei dentro do carro levamos para as professoras de lá. As professoras fizeram, e disseram que eles fizeram uma molhadeira dentro da sala [...] E amolecada ficou pintando os desenhinhos. Eu falei -gente. Olha só para os trabalhinhos que essa molecada faz. Porque esses professores em vez de ficar gritando com essa molecada, não dá um negócio desse pra essa molecada se divertir. Vai dar problema para você limpar a sala depois, mas, claro que vai. Mas, puxa vida, é uma coisa tão construtiva. A molecada aprende tanto e a gente vai ter tão pouco problema quando essa molecada chegar no ensino fundamental. Porque eles chegam com um olhar diferente. Eles conseguem escrever de uma forma diferente, consegue até fazer conta de uma forma diferente.

O que seus pais acharam de ter um filho professor?

[...] E eu não vivi com minha mãe. Este negócio de laço familiar eu não tenho. Eu tenho mais laço familiar com meus primos do que com mãe, com pai, com avô, com avó, porque eu vivi um tempo com um, um tempo com outro, mas os primos estavam sempre juntos. Era incrível. Como eu sou o primo mais velho. Eu tenho trinta anos e minha prima mais nova tem 22. Acho que eu fui o pivô da família de lá para cá. Porque quando eu comecei a fazer faculdade a família inteira voltou para mim. Foi o primeiro membro da família a ir para uma universidade. Na realidade, eu sou o primeiro da família que conseguiu fazer o ensino médio. Minha família toda parou na sétima série e tal. Eu fui o único que continuou no ensino médio. Tanto que eu tenho uma tia que parou, acho que na quarta série, e ela voltou a estudar. Ela esta fazendo supletivo. Ela tem 43, 44 anos e está fazendo supletivo porque ela quer se formar. E eu vou dar aula para ela, olha que legal (risos). Então acho que assim: a minha família, minha mãe, eu acho que eles gostam de ter uma pessoa da família que é professor, que fez faculdade e agora está fazendo mestrado e provavelmente mais para a frente vai fazer doutorado, né. Então, uma pessoa que é letrada na família. Eles me chamam de catedrático.(risos).

Então, por ser o sobrinho mais velho, o neto mais velho, o sobrinho mais velho sou arrimo da família. O povo se apóia, até os tios se apóiam em mim. Eu tenho esta tia que voltou a estudar. Tenho uma outra tia que eu estou enchendo o saco dela para voltar a estudar. E ela é inteligente pra caramba, tem muito conhecimento. Fez curso de enfermagem, fez um monte de coisas. É uma pessoa que evolui. Mas, por não ter tanto contato assim com minha mãe um pouco da minha família gosta de ter um professor na família. Principalmente para ajudar os primos (risos).

[...] E eu acho que o primeiro dia que eu entrei na sala de aula os alunos olharam pra minha cara e é claro novinho os alunos olharam para a minha cara e pensaram que eu era aluno e..foi tudo mundo entrando e um povo foi saindo e aí eu falei. Pessoal estou esperando vocês pra dar aula. Ah. Você é professor. Ah ..como você está? E pra mim não foi tão difícil porque é assim eu já tinha trabalhado na estação ciência , né, com alunos ....não era professor mas era monitor, e explicava todas aquelas coisas de física, aqueles negócios todos e é..no caso da estação ciência era um negócio mais light mais sossegado e então pra mim eu já tinha desenvoltura na época, então não foi tão pesado, tem para alguns professores que foi pesado o primeiro dia, mas para mim não foi tão pesado, não, e por outro motivo também, eles moravam na Brotolândia e eu também morava, né ele moravam no Jardim Soares eu Morava no Jardim Maria Emilia que era outro lugar da Brotolândia e que também era boca quente. 